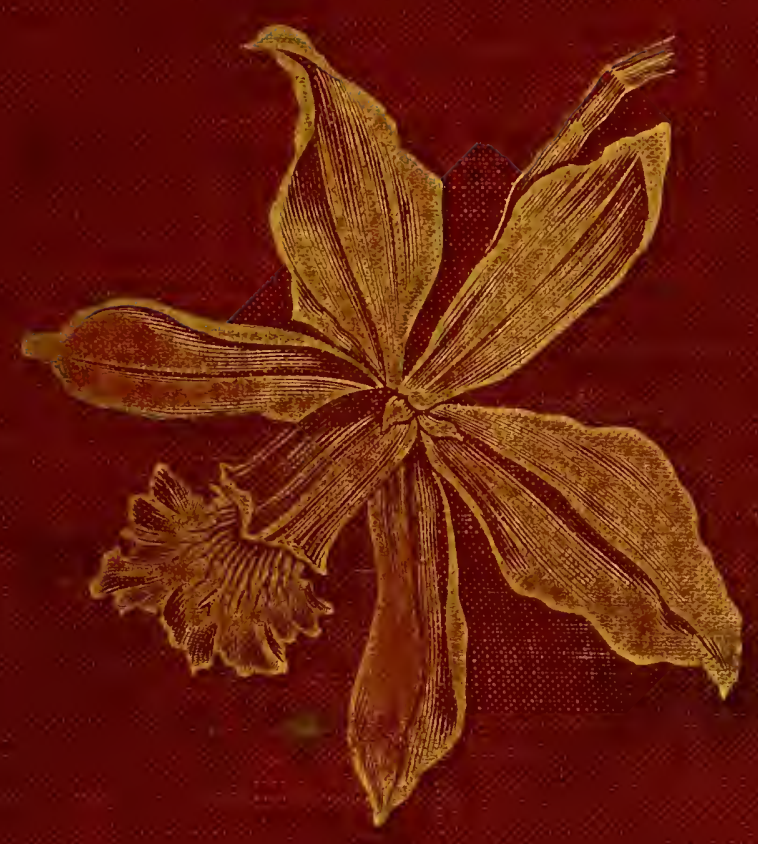




\section{THE LIBRARY OF BROWN UNIVERSITY}

\section{THE CHURCH COLLECTION}

\section{The Bequest of}

Colonel George Earl Church $1835-1910$ 




A NATURALIST IN THE GUIANAS 




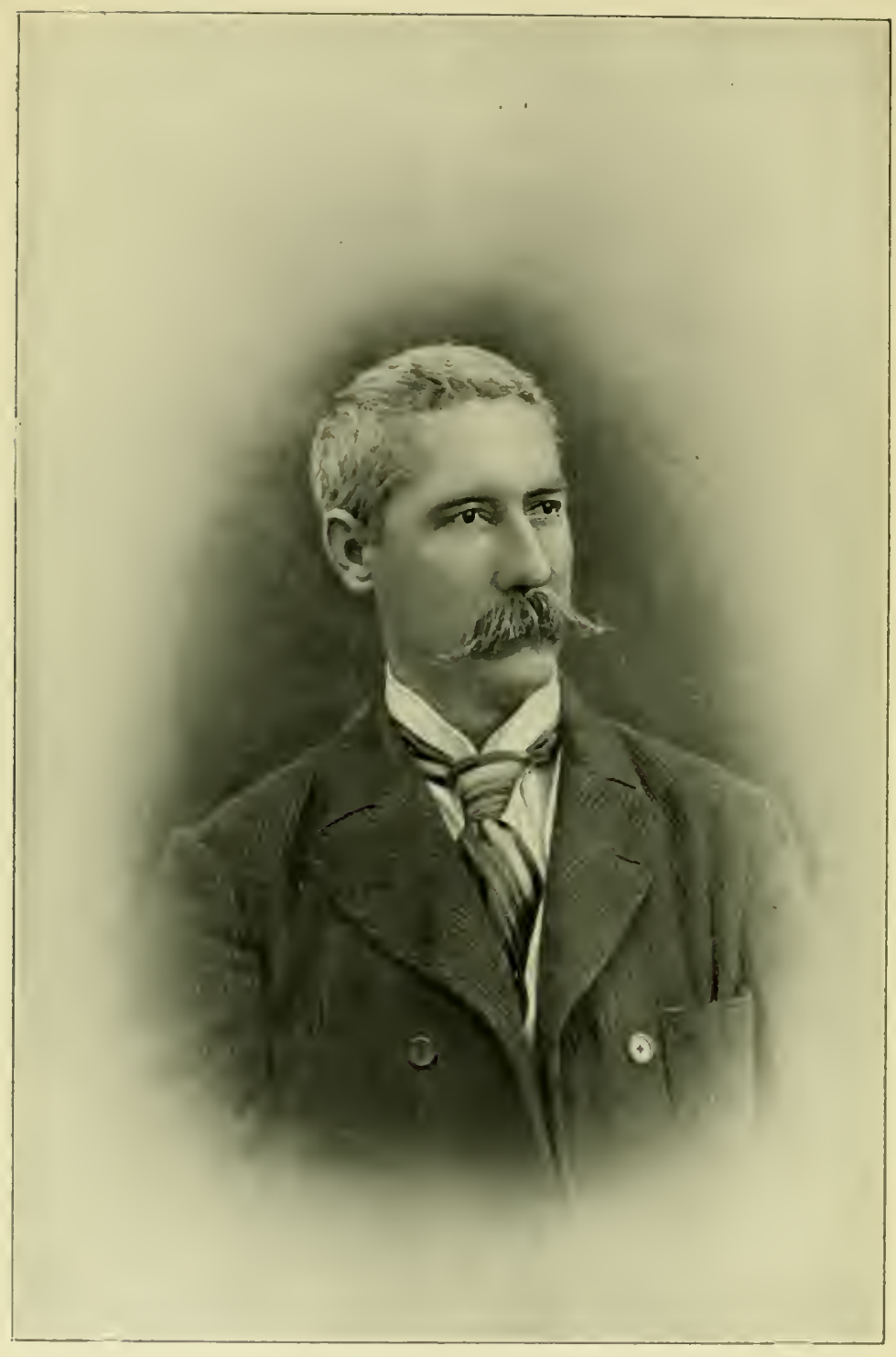

yours fartereet,

novemter, igo- 


\section{NATURALIST IN THE}

\section{GUIANAS}

BY

EUGÈNE ANDRE, F.R.G.S., F.Z.S., M.S.A.

WITH A PREFACE BY DR. J. SCOTT KELTIE (SECRETARY OF THE ROYAL GEOGRAPHICAL SOCIETY)

WITH THIRTY-FOUR ILLUSTRATIONS

AND A MAP

\section{LONDON}

SMITH, ELDER, \& CO., 15 WATERLOO PLACE 1904 
$2=71$

$$
-1<2^{\prime}
$$




\section{P R E F A C E}

I HAVE been asked by Mr. André to write a brief preface to the following account of his journeys up the Caura affluent of the Orinoco, and feel that I cannot well refuse to do so, especially as the author declares that I am in a measure personally responsible for the appearance of the narrative in its present form. But if the reader will turn to the narrative itself, he will quickly discover that no preface is needed to proclaim its merits. In the Geographical Journal for September 1902, a paper by Mr. André summarised the results of his latest journey and described his ascent of Mount Turagua. But Mr. André is still more a naturalist than a geographer, and in particular he has made valuable additions to our knowledge of the bird life of the great Venezuelan forests, as Dr. Hartert of the Tring Museum has abundantly testified.

It is not, however, by any means only the scientific student who will find much to interest him in Mr. Andre's narrative. In no region of the world is travelling more full of incident, more prolific in perilous adventure, than in the dense tropical forests and along the mighty streams of the still practically virgin areas which form so large a part of the South American continent. Mr. André himself suffered shipwreck in the Arichi rapids of the Caura 
river, and only reached one of the poor little settlements scattered along its banks after a journey of twenty-six days, during which six men out of a party of fourteen succumbed to the hardships endured. Life amid these forests, in the innermost recesses of which strange creatures have their abode; where vegetation grows in rank, masterful luxuriance; where indefinable, mysterious influences seem ever to be at work-seem, indeed, an essential accompaniment of the hot, dank vapours which rise from the rotting undergrowths; life amidst these surroundings takes on curious aspects. It is not surprising that the few Indians who inhabit the sparsely populated country through which the Caura flows should be imbued with a nameless dread of the evil spirits and terrible demons that dwell among the mountains and manifest their presence in the thunder and lightning of the tropical storms that rage with such resistless violence.

The particular region which Mr. André visited in 1900 is doubly interesting as the scene of the adventures and sufferings of the ill-fated party of emigrants from England who were induced by an unscrupulous advellturess to try their fortunes in this remote part of Venezuela. The enterprise was a hopeless failure, and the story of the dogged struggle of the emigrants against the dangers from man and beast which confronted them, and the other difficulties of their situation, is as thrilling and of as absorbing interest as any production of the imagination. There still lives at Ciudad-Bolivar the son of a leading member of this tragic enterprise, who tells how his father had more than once to go alone a distance of a mile or more with two pails of water, carrying a revolver between his teeth with which to defend himself on the 
way. No other man of the party was well enough to walk.

Mr. André is well qualified to tell the fascinating story of wild life in regions such as these-and there is a fascination about the life, not only for those who can sit at home and read at their ease of travel and adventure in far-off lands, but for those who have had actual experience of its hardships and its charms. Mr. André is descended from a Huguenot family which emigrated from France to Virginia after the revocation of the Edict of Nantes. His grandfather settled in the island of Trinidad, which, as is of course well known, lies close to the coast of Venezuela. $\mathrm{He}$ has for ten years past devoted himself to travelling in Venezuela and Colombia, collecting orchids, birds, butterflies, and small mammals. His first visit to the Caura river lasted from September 1897 until May 1898. So encouraging were the results of this trip that in $1900 \mathrm{Mr}$. André renewed his investigation of this region, and ascended the river to within five degrees of the Equator. Subsequently he published in Trinidad a narrative of the journey for circulation among friends, and the reception accorded to this led to his drawing up the following account of his travels. Mr. André's narrative records the results of a piece of work really interesting and fruitful of scientific results.

J. Scott Keltie. 



\section{CONTENTS}

\section{CHAPTER I}

The Orinoco and its tributaries, the Ventuari, Caura, and Caroni- 1 Dorado-The Caura and Merevari-Headless men of the CauraThe tonca-bean tree-The tonca-bean industry-A trip to the Caura arranged . . . . . . . . .

\section{CHAPTER II}

First visit to the Caura, September 1897-May 1898-La Prision-Exploration of Turagua-Departure from La Prision-Old Guachee's house-Tramp through the forest-The jaguar-Method of shooting paujis-Tortoises-Gnats-Indian method of walking-Forest fruits-Ascent of the mountain-The water-vine-The Peak-A plague of flies-We leave the mountain-A journey to Améha arranged .

\section{CHAPTEP III}

History of the Orinoco steamers-Seizure of the steamer 'Bolivar'Departure from Trinidad-The hammock-Gambling on boardGuaraunos-Barrancas-Guayana la Vieja_Ralegh and Guayana la Vieja-Simon Bolivar and Los Castillos-San Felix-El Callao mine-The Caroni-Ciudad-Bolivar . . . . . .

\section{CHAPTER IV}

Ciudad-Bolivar-Construction of the houses-Malaria-Notes on the town-Navigation of the Orinoco-Rise and fall of the OrinocoThe Orinoco as a highway-Exports-The trade in feathers-The trade in balata gum-Export duties-Salt-pans-Salt monopolyAraya-Formation of salt deposits-Smuggling of salt-LeprosyStrange method of fishing . . . . . . . 


\section{CHAPTER V}

Cock-fighting and its history - The training of cocks in VenezuelaThe cockpit-Bull-fighting-Carréras de Cintas-Golfo-Paro pinto-Monte de dados-Gambling banks . . . . .

\section{CHAPTER VI}

Departure from Ciudad-Bolivar, December 6, 1900-The chubáscoThe Gates of Hell-Alligator hunting-Trade in alligator skinsOn board the 'Caura - Fish spearing by torchlight_Mapire

\section{CHAPTER VII}

Humboldt's description of the Caura-Llanos of the Caura-Cattlerearing-Revolution of 1898-Waterfowl-Puerto Antonio Liccioni -Mosquitos and flies-Maripa and Aripao-Pinta disease-The Mato-Piaroas-Cormorants-La zona de los bosques . . .

\section{CHAPTER VIII}

Temblador-Departure for La Prision-La Prision-Ants-Our quarters-Method of keeping accounts-House building . .

\section{CHAPTER IX}

\section{LA PRISIOA}

Manufacture of sugar-Method of packing-Molasses and stillsTrade-Cabbage palm and grub-Faculties of insects-Hunting and fishing-Fishing with dynamite-Rise and fall of the CauraVoracious fish-In dreamland. . . . . . .

\section{CHAPTER X}

FAUNA AND FLORA OF LA PLISION-THE CLEARING

Hornets-Butterflies-Nightjars-The wood-nightjar-Hawks-Thc Guaco-Rice-birds-Ants and ant-thrushes-Man and the other animals-Utopia . . . . . . . . .

\section{CHAPTER XI}

FAONA AND FLORA OF LA PIISION-THE FOREST

Bejucales-Curassows, grullas-Tinamus-Habits of curassows-The king-tody and other flycatchers--Scarcity of snakes in the forestThe jaguar-Orchids-The lajas-The evenings at La Prision 


\section{CHAPIEI XII}

EXPEDITION TO THE NICHARE, DECEMBER 22, 1900, TO JANUARY 28, 1901. FRON LA PRISION TO THE MOUTH OF THE NICHARE

Indians-Preparations for our departure-Departure from La Prision -Dug-outs-Rapids of Mura-TVater plants and tapirs-Burrowing birds-Indian settlement at Mura-Strange-looking trees-Christmas on the Caura-Facundo returns to La Prision-The Nichare .

\section{CHAPTER XIII}

EXPEDItion to the NTCHARE, DECEMBER 22, 1900, то JANסARY 28, 1901. THE NICHARE

My first tapir-Morocotos-Otters-The rubber industry-The rubber on the Nichare-Establishment of settlements-New birds obtained -News of Facundo's death-Return to La Prision . . .

\section{CHAPTER XIV}

La Prision, January 28-February, 22, 1901-Peccaries-Method of camping-Water tortoises-Eggs of the water tortoise-ParaOrchids-Indian method of carrying loads-Flies and ants-Above the Falls of Para-Tapir hunting . . . . . . .

\section{CHAPTER XV}

Guayarapo-Ayaima-Block-houses on the Erewato-Tapir hunting - Strange superstitions-Achaba-The sun-bittern-SuraimaDining under difficulties.

\section{CHAPTEP XVI}

Colonies of hang-nests-We push on to Améha-The tapir-Accident to the large boat-First sight of Améha-Insects and a bright light-We kill another tapir-Iguanas-Améha . . . .

\section{CHAPTER XVII}

A.IEHA

Inaccessible mountains-The koa bird-Concerning our taxidermistJourney to the cliffs-At the foot of the cliffs-Storm at nightWe return to our camp-Further attempts to scale the mountain -We leave the mountain 


\section{CHAP'TER XVIII}

Our last tapir-Arawa and Arichi-The fatal April 27-Loss of the large boat-We arrive at a decision-A night of misery-Mateo bitten by a snake-Treatment of snake-bite-Slow progress through the forest-The men build a raft-The kosoibo-Sufterings of the men-Suraima-We begin to starve-In desperate straits-The men decide to separate

\section{CHAPTER XIX}

We separate-Achaba-The giant armadillo-Dogs attacked by a puma-Guayarapo-Maite loses his reason-Death of our guide - Para-IVe leave Para-We reach Mura-Back at La Prision

\section{CHAPTER XX}

Departure of the relief party-Juan Silva's wife-IVith the IVaiomgomos-Cotton-spinning-A primitive dark-room-Orchid collecting-Cassava-Yaraqué-Basket-making-Returu of the relief party-Canoe-building-Agriculture-Treatment of children-The blow-pipe-Isidor-Departure from La Prision-On the Orinoco again

Conchusion . . . . . . . . . . . . . . . 304

INDEX • . . . . . . . . . . . 305 


\section{LIST OF ILLUSTRATIONS}

Portrait of Eugh̀ne Andrú (with autograph) Nov. 1900 Frontispiece Making Arrows - $\quad$ - . $\quad$. $\quad$. $\quad$. To face page 6

Cleaning Orchids (Cattleya SUPerba) • . . " "

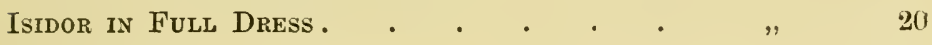

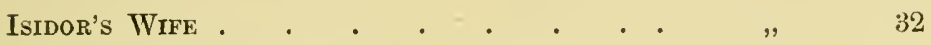

Making Hamiock . • . • . . . , , 40

Guarauno Settlement-Delta of the Orinoco. "

Los Castillos, formerly Guayana la Vieja Where Young Ralegh Was Killed . . "

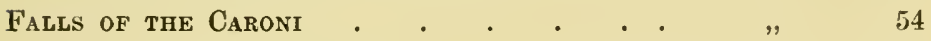

YOUNG OF THE SNOWY EgRET . . . . . " ,

RIVER-Front-CIUDAD-Bolivar . . . . ", 72

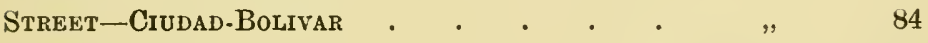

RAPIDS OF MURA . . . . . . . " " 102

With the Waiomgonos-Primitive SUgar Mill,$\quad 196$

Balling Cotton . . . . . . . . "

Waiomgomos Fishing . . . . . . " " 1334

Butterfles . . . . . . . . " " 142

The King-Tody (Muscivora coronata) coloured ", 158 
Waiomgono Children . . . . . . To face page 166

With the Waiomgonos-Vicente . . . " " 170

ViCENTE'S VIrE . . . . . . . . "

Christuas on the Caura . . . . . . . . 178

ON the Nichare-Tapping a Rubber Trek . . "

Calliste Paradisea (coloured) . . . . . " , 190

MAKING BASKETS . . . . . . . " 202

Matte, the Guidh who afterwards died of Starvation . . . . . . . " 230

Portrait of Eugìne ANdrí, May 1901 (at the end of the Expedition) . . . . . . " , 258

The Survivors at La Prision . . . . . " 270

Arrival of the Survivors at la Prision . . " " 282

Departure of the Relief Party . . . „ " 284

Spinning Cотton . . . . . . . . " 286

With the Waiongonos-Grating Cassava . , 290

The Relief Party . . . . . . . " " 294

IVith the Waiongomos-Augustin the Flute

Player . . . . . . . . " 300

Map showing the Routes of the Expeditions on the Caura Rivir . . . . . . . . 310 


\section{A NATCRALIST IN THE GUIANAS}

CHAPTER I

The Orinoco and its tributaries, the Ventuari, Caura, and Caroni-E1 Dorado-The Caura and Merevari-Headless men of the Caura-The tonca-bean tree-The tonca-bean industry $-A$ trip to the Caura. arranged.

IF we look at a map of Venezuela, we shall observe that the whole country, with the exception of a small portion on the northern seaboard, is drained by the Orinoco. This huge artery, which rises somewhere on the confines of Brazil, in a range of mountains vaguely marked on maps as the Serrania de Parime, forms in its course a gigantic fishhook-like bend before flowing in an almost straight line towards the east to fall into the Atlantic. On its right bank, and rising in the region contained within the bend, three important rivers-the Ventuari, the Caura, and the Caroni-flow into the Orinoco. The sources of these tributaries are not far from each other. In the case of the Ventuari and the Caura in particular, the headwaters of both streams are so close together that a journey up one river and down the other would not present any insurmountable difficulties, but these courses are in directions so divergent that the points where their waters are lost in the brown flood of their mighty parent lie more than 500 miles apart. Quite a number of smaller 
streams, such as the Sipapo, Cuchivero, Suapure, fall into the Orinoco and drain the country between the Ventuari and the Caura, but so little has been done in the exploration of the region through which they run, that the courses of these streams as laid down on maps must be looked upon as being merely approximate and not by any means accurate. Unlike the affluents of the left bank, like the Meta and the Apure, which flow for the most part through grassy treeless plains, the tributaries on the right, rising in the unexplored tableland forming the watershed between the basins of the Amazon and the Orinoco, are rapid in their descent to the lowlands, and they rush through a region of dense forests and numerous isolated mountains and mountain ranges. While the navigation of the Apure, the Meta, and the other streams of the plains is comparatively easy, although encumbered by sandbanks during the dry season, that of the affuents on the right hand, especially the Caroni and the Caura, is difficult and dangerous.

Three centuries have passed away since the first adventurers tried to reach the Golden Land supposed to exist somewhere near the sources of these rivers, yet our knowledge of the far interior of the Guianas remains shadowy and indefinite. After the conquest and spoliation of the Inca kingdom, the cities of the Andes held many bands of needy adventurers. They consisted of men, some of whom had accompanied the conquistadores in their first descent upon the land of the children of the sun, and had squandered in wild excesses the gold they had acquired so easily ; while others, who had been lured by the stories of the fabulous wealth of the new country conquered by Pizarro, had hurried in numbers from the shores of Europe to find, after a long and tedious voyage, 
that the riches of the land had been secured by the firstcomers.

It is easy to understand how, out of the longings of these needy and restless spirits, there grew a belief, which gradually shaped itself into a certainty, that far away towards the east there lay a land of plenty, compared to which the kingdom of the Incas was but a barren waste. Why should there not be in a country so vast other and richer empires than those of Montezuma and Atahualpa? And it is not improbable that the viceroys and such citizens as had acquired wealth and power did much to encourage the belief in a distant country teeming with gold and precious stones. It was an easy way of getting rid of men who must have been importunate, if not dangerous, fellow-citizens. Thus it came to pass that many expeditions left the plateau of Quito in search of the Golden City on the shores of the Lake of Parime.

The Indians, whom these early explorers visited, eager in their turn to rid themselves of such unwelcome guests, found it to their advantage to confirm the stories of a wealthy country far away in the direction of the rising sun. So that the few who returned from these first expeditions, so fraught with danger and hardships, brought with them many detailed accounts gathered in their wanderings of the wealth and beauty of the wonderful city of Manoa, with the result that fresh bands of adventurers started in search of the kingdom of the Inga, each band hoping to be more successful than its predecessors. In spite of the failure of expedition after expedition, the fable of El Dorado continued to exert an extraordinary influence on the more adventurous spirits of the times, of whom Sir Walter Ralegh was one of the most prominent. It was not until the beginning of the 
eighteenth century that Humboldt finally dispelled the mythical beliefs that clung to the El Dorado of the conquistadores. The veil of enchantment which shrouded the unexplored interior of Guiana has been torn aside. In place of the fairy city gleaming with gold and precious stones, with a vast population revelling in luxury, we now know that there is an immense stretch of impenetrable forest interspersed here and there with open savannas, with mountains of fantastic shapes and surpassing grandeur, rising abruptly from the surrounding country - a region of abundant rains and rapid rivers, thinly peopled by small tribes of Indians who for centuries have carried on a series of cruel blood-feuds with their neighbours-a region rich in bird, insect, and vegetable life, but difficult of access and deadly in climate. Beyond this our knowledge is vague and uncertain, and is likely to remain so for some time to come. The difficulty of navigating rivers which consist of a series of rapids and falls, the utter absence of population for considerable distances on their banks, the almost impossible task of transporting a sufficiency of provisions where only boats of no great size can be employed on account of the frequent portages, make the exploration of the highlands of Guiana an undertaking replete with danger and hardships. Added to these natural difficulties there is a rooted disinclination on the part of the natives to undertake long and arduous journeys outside of the immediate district with which they are familiar.

Of all the rivers Howing through this region none is more picturesque than the Caura, but none is more difficult to navigate. Under the name of the Merevari it rises near where the Pacaraima and Parime mountain ranges meet. For a short distance it flows almost due 
south, skirting that part of the Pacaraima range known as the Cerros Merevari. Early in its course it receives on its right the Emecuni, near to which the Waiomgomos have their largest house or compound, then it flows in an easterly direction for about 60 miles, when it turns almost due north to fall into the Orinoco after a total course of over 500 miles. The bend which the Merevari forms before meeting the Canaracuna on its left bank, is so irregular and broken by falls and rapids that the Indian traders from the Chawarro, rarely, if ever, attempt to reach the Waiomgomo houses by this route. They prefer to ascend the Canaracuna and follow its small tributary, the Yapecuna, for a short distance. A journey of two days over exceedingly rough country takes the traders to the Merevari, where there is sure to be a woodskin. ${ }^{1}$ By crossing the Merevari and ascending the Emecuni the Indian settlement is reached. Between this settlement and that at the rapids of Mura, a distance of about 250 miles as the crow flies and 400 miles following the windings of the river, no human habitation is met with. When the Spaniards first visited this region the banks of both the Caura and Merevari supported many tribes. If the names of the various tribes and villages entered on some Spanish maps be correct, we find it difficult to account for the complete extermination of so many people in so short a space of time. Even so late as 1840 Codazzi mentions several tribes of which no trace remains to-day.

Of the beliefs which prevailed in the early part of the sixteenth century respecting the inhabitants of this part of Guiana we may gather some idea by referring to Sir Walter Ralegh's quaint work 'The Discovery of Guiana ':

1 Woodskins are small canoes made of bark, used all over Guiana. 
'And on that branch which is called Caora are a nation of people whose heads appear not above their shoulders, which though it may be thought a mere fable, yet for mine own part I am resolved it is true, because every child in the provinces of Arromaia and Canuri affirm the same. They are called Ewaipanoma. They are reported to have their eyes in their shoulders, and their mouths in the middle of their breasts, and that a long train of hair groweth backward between their shoulders. The son of Topiawari, which I brought with me into England, told me that they are the most mighty men of all the land, and use bows, arrows, and clubs thrice as big as any of Guiana or of the Orinocoponi and that one of the Iwararaqueri took a prisoner of them the year before our arrival there and brought him into the borders of Arromaia, his father's country.'

When we consider that this was written by a man looked upon as one of the greatest of his time, we cannot help being struck by that curious tendency on the part of man in every age to believe in the supernatural and incredible. The story of the headless men of the Caura, like the pigmies warred on by cranes on the shores of old Oceanus, now belongs to the domain of fable.

It is probable that the first missionaries travelled over a considerable part of the Caura. They established a mission at the mouth of the Erewato above the falls of Para, but no trace of their work remains to show the exact spot where the old mission stood. With stations on the river its navigation was easier than it is to-day, when the whole country is nothing but a wilderness of interminable forest. The Waiomgomos who accompanied me said that on the Nichare there are still some Taparitos, but none of them would dare to visit the spot, for this 


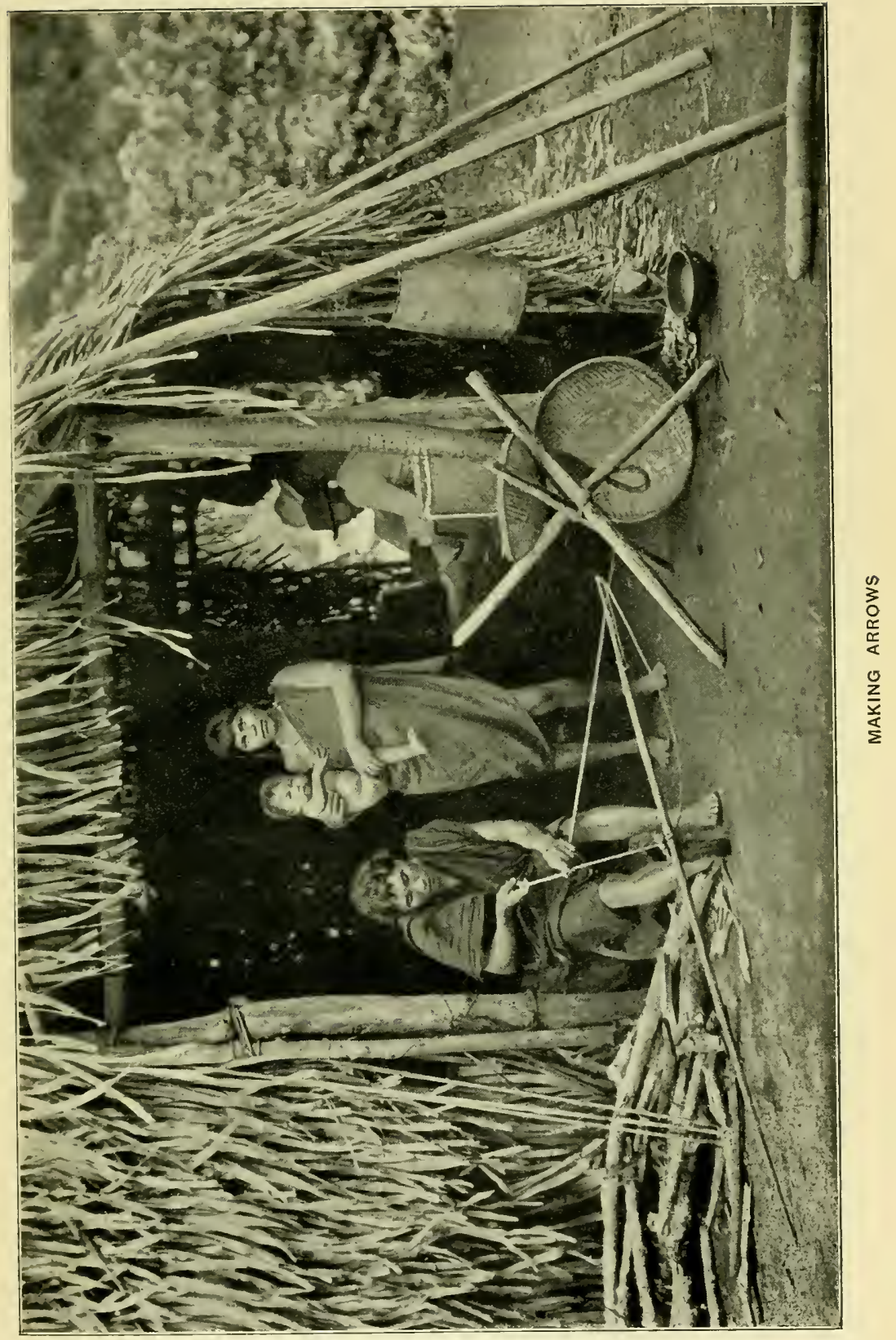



tribe is at feud with all others; they are the Ishmaelites of the Caura. If Taparitos still exist on the Nichare, it must be in the mountains at the very source of the stream, or at some distance from its banks, for when I subsequently explored this river for a considerable distance, no signs of any Indians were met with.

That part of the Caura between the mouth of the Nichare and the Orinoco is fairly well known to the Venezuelans of the district engaged in tonca-bean collecting, but in their quest for this product they rarely go beyond Cangrejo, a three days' journey in boats after leaving the last settlement at the rapids of Mura, and two days from the mouth of the Nichare.

So bound up is the existence in this district of the tonca-bean tree with the presence of the stations of Suapure, Temblador, and La Prision on the banks of the Caura, that any description of the river would be incomplete without some reference to the industry that has given birth to and continues to foster these stations.

The Tonqua, Ton-ka, or Tonquin bean of commerce, first reached Europe from the Chinese province of Tonquin. It is the dried seed of the fruit of Dipterix odorata, and it owes the peculiar odour for which it is valued to a crystallisable principle known as coumarin. At least two other known members of the vegetable kingdom, Melilotus officinalis and Anthroxanthum odoratum, are indebted to the same principle for their fragrance. The tree has been found in different parts of tropical America, but the product exported from Para appears to be inferior to that which comes from the region in the vicinity of the Caura and the Cuchivero rivers. The watershed between these two streams consists of several mountain ranges of granitic formation, the 
most considerable of which is the Serrania de Mato. On the right bank of the Caura mountains of similar formation, of which Turagua is the highest point, also exist. The average altitude of these ranges is between 3,000 and 4,000 feet, but there are peaks that attain an elevation of nearly 6,000 feet. Besides the mountain ranges many isolated hills and large open masses of granite, only a little higher than the surrounding country, are scattered through the forest. The land in the vicinity of these mountains and lajas consists largely of granitic grit, and it is in this soil that the tonca-bean tree appears to be at home. Although met with in patches this tree is not by any means gregarious, so that the collecting of the fruit is arduous work.

So irregular are the crops that it is almost impossible to forecast the yield of any particular year. It may however be taken as a general rule, that for one or two years after a plentiful harvest the production is so scant that it does not pay to collect beans. In Venezuela the tree is known as sarrapia and the men engaged in the collection of the seed are called sarrapieros. The sarrapieros begin to arrive on the Caura early in February. Some of them come from considerable distances; a good many are from Ciudad-Bolivar.

During the months of October and November, while the fruit is still quite small and green, the large macaws and several other members of the parrot family commit great havoc upon the young crop. No birds are more extravagant than parrots in their method of feeding, not so much on account of what they consume as of what they waste. Wherever these birds have eaten the ground is strewn with fruit only clawed and then awkwardly dropped, or perhaps with just a small piece bitten off. 
Hence the destruction before maturity of enormous quantities of this valuable product.

All through February and March the Caura, so deserted at other times, presents a scene of activity; many boats are met with struggling against the powerful current of the stream, from the large bongo or dug-out, of several tons, with an entire family, to the frail skiff handled by two men. Those of a more enterprising disposition fit up expeditions of two or three bongos and employ quite a number of hands. This is a time of plenty for the inhabitants of the place. Progress up the river is slow and the boats make frequent stoppages for the purpose of purchasing fresh provisions and rum. Whereever there is a settlement the men will land and most of them get drunk. The old visitors usually stop at the spots leading to the sarrapiales with which they are familiar: they know every inch of ground, every toncabean tree in the district. Caño Guayapo, Suapure, Temblador, and La Prision are the settlements where most of the boats stop. Some of the more energetic sarrapieros push on as far as Cangrejo, but it is hard and risky work getting through the rapids of Mura and Piritu. So soon as a party has selected a spot as a centre of operations, the men build the ranchos or huts which for two or three months will be their home. If the fruit has commenced to fall, collecting begins at once; if not, the men wander about the forest noting the spots where fruit is plentiful, or they while away the time fishing and hunting. Every member of a family or party-man, woman, and child-takes part in the collecting. At daybreak the work commences, the workers separating so that no fruit-bearing tree may be overlooked. After the trees in the immediate neighbourhood of the ranchos have 
been exhausted, the sarrapieros wander farther into the depths of the forest; often they undertake expeditions to considerable distances and remain a week or a fortnight away. During this time they sleep in the forest, slinging their hammocks between trees with a slight covering of wild plaintain-leaves or palm-branches to keep the rain off.

The fruit of the sarrapia is much like a mango in appearance and is largely eaten by the natives. It has. but little pulp, which is sticky and of insipid taste, the seed being covered with a hard fur-like substance. After the sarrapicro has got together a sufficient quantity of fruit, he takes his find to some open spot where he can get the benefit of strong sunlight. The hard shell is then carefully broken between two stones, and a single oblong bean of a dark-brown colour obtained. The seeds are then. spread out to dry, generally upon the large open masses of granite called lajas which form so peculiar a feature of the forests of this region. These dried beans form the sarrapia or tonca-bean as it is sold by the sarrapiero to the merchants of Ciudad-Bolivar, where the process of crystallisation, as it is called, is sometimes carried out. This. operation, however, costs very much less if performed in Trinidad, where the strong rum required for the process can be obtained at a cheaper rate than at Ciudad-Bolivar. By the end of May or the beginning of June the last beans have been taken, and the crop may be said to be over. The boats descend the river, stopping at every settlement, and the sarrapieros get drunk whenever they can as they did three months before, for the curse of the Venezuelan peon or labourer is his fatal fondness for ardent spirits. When the men reach Ciudad-Bolivar, they dispose of their product to one of the big export-houses. It does not take 
long for what they have earned to disappear in the round of parrandas ${ }^{1}$ and fiestas ${ }^{2}$ the peon loves to indulge in when he has money. But the profits of the sarrapieros are not what they used to be, for the days when toncabeans were worth three or four dollars the pound have passed away, to the benefit of the tobacco manufacturer of the United States, the only market for large quantities of this product. The beans are never shipped in the raw state ; they are treated with strong rum, the process being called ' crystallising.' Puncheons open at one end, having been placed in a row, are filled with beans to within a foot or eighteen inches of the top. Strong rum is then poured into the puncheons until they are quite full, when they are covered over with layers of bagging. At the end of twenty-four hours the rum not absorbed is run off, and the beans are spread out to dry in a current of air. When first taken out of the puncheons the beans are of a dullblack colour and are soft and swollen; but on drying, shiny white crystals appear on their surfaces, and by the time they are ready for packing they look as if they had been sprinkled over with powdered sugar. They have shrunk a good deal and are wrinkled in appearance. They are then put into wine-casks or rum-puncheons and are ready for shipment.

In referring to the tonca-bean industry I have touched upon a subject intimately connected with my two voyages to the region I have just roughly described, for it was as the guest of a gentleman who was deeply interested in this industry that I paid my first visit to the Caura in the latter part of 1897 . Some time in the eighties, it must have been! in 1885 or 1886 , I made the acquaintance of Mr. J. B. Richard, who was on his way

1 Serenades.

? Feast-days. 
to Venezuela as one of the superintendents of the Sociéte du Haut Orénoque. This concern was a company formed for the purpose of exploiting the forest products and supposed mineral wealth of the country on the banks of the Upper Orinoco. It was started with a large capital. Its operations were undertaken on a magnificent scale. Expensive steamers were sent out with men who knew absolutely nothing, not only of Venezuela, but of anything connected with the tropics or tropical products. After large sums had been wasted the concern collapsed, leaving in the lurch those of its employés who had not returned in disgust to their native country, or who had been fortunate enough to escape from the malarial fevers to which many had fallen victims. I had almost forgotten the Société du Haut Orénoque and my old acquaintance, Richard, when I ran up against him one afternoon in August 1897, close to the club in Port of Spain. We spent the rest of the day together comparing notes, he telling me all about his travels on the Orinoco, I relating events connected with my orchid and bird collecting excursions into the northern mountain range. It was at dinner, while he was speaking of his plans for the future, that he said to me suddenly, 'I am going to the Caura at the end of next month; why don't you come with me?' Before we parted I had agreed to join him in CiudadBolivar by the end of September. 


\section{CHAPTER II}

First visit to the Caura, September 1897-May 1898-La Prision-Exploration of Turagua-Departure from La Prision-Old Guachee's house-Tramp through the forest-The jaguar-Method of shooting paújis-Tortoises-Gnats-Indian method of walking-Forest fruitsAscent of the mountain-The water-vine-The Peak-A plague of flies -We leave the mountain-A journey to Améha arranged.

As my first visit to the Caura was more in the nature of a pleasure-trip than a regular voyage of exploration, I did not keep any extensive notes, but simply jotted down from time to time such incidents as I considered most interesting. Only in the case of the expedition to the mountain of Turagua did I keep a regular diary and enter into details. I have thought it necessary to mention this so as to explain why the narrative of my first journey to the Caura is a short one.

I left Trinidad by the steamer 'Bolivar,' on September 22, 1897, accompanied by a taxidermist and a hunter. We passed Barrancas and San Felix on the following day and reached Ciudad-Bolivar at noon on Friday, the 24th. A week was spent in preparations for the journey, as Richard, who intended to explore the Nichare, one of the tributaries of the Caura, was taking thirty men with him and a quantity of provisions and other articles for the long stay he intended making in that hitherto unexplored region. Early on the morning of October 1 we went on board the little 'Caura,' and within an hour we were well on our way to the river 
whose banks, according to Sir Walter Ralegh, were peopled with a strange race of headless beings. What with the number of men and boats, and the quantity of cargo we carried, our small steamer was as loaded as she possibly could be, and we had but little room for moving about. Our pilot kept close either to one bank or the other, so as to avoid the full force of the current, and this allowed Richard and myself to lay wagers on our respective merits as marksmen by shooting at the alligators or wild ducks on the sandbanks. At about one o'clock in the morning of the third day after our departure from Ciudad-Bolivar, we reached the mouth of the Caura. As it was a very dark night we did not enter the river until daybreak. At three in the afternoon we arrived at the landing-place of the village of Maripa, where the steamer was moored for the rest of the day so that we might visit some ricefields in which Richard was interested and at the same time replenish our stock of firewood. On the following morning we steamed up to Suapure, where we remained until October 10, Richard being engaged inspecting the tonca-bean forests and making arrangements with the people of the place for collecting the beans. Four days after we got to La Prision, which I made my headquarters during our stay of eight months on the Caura, and it was from this settlement as a base that I explored Turagua, the most important of the mountain masses existing in this region. This trip was undertaken with the definite idea of obtaining rare and valuable orchids, the mountain having appeared to me a likely spot for such plants. It was not until March, however, that I was able to carry out my project, the weather having been so rainy up to that time that the streams in the forest were impassable. On the 8 th (March) the Indians 


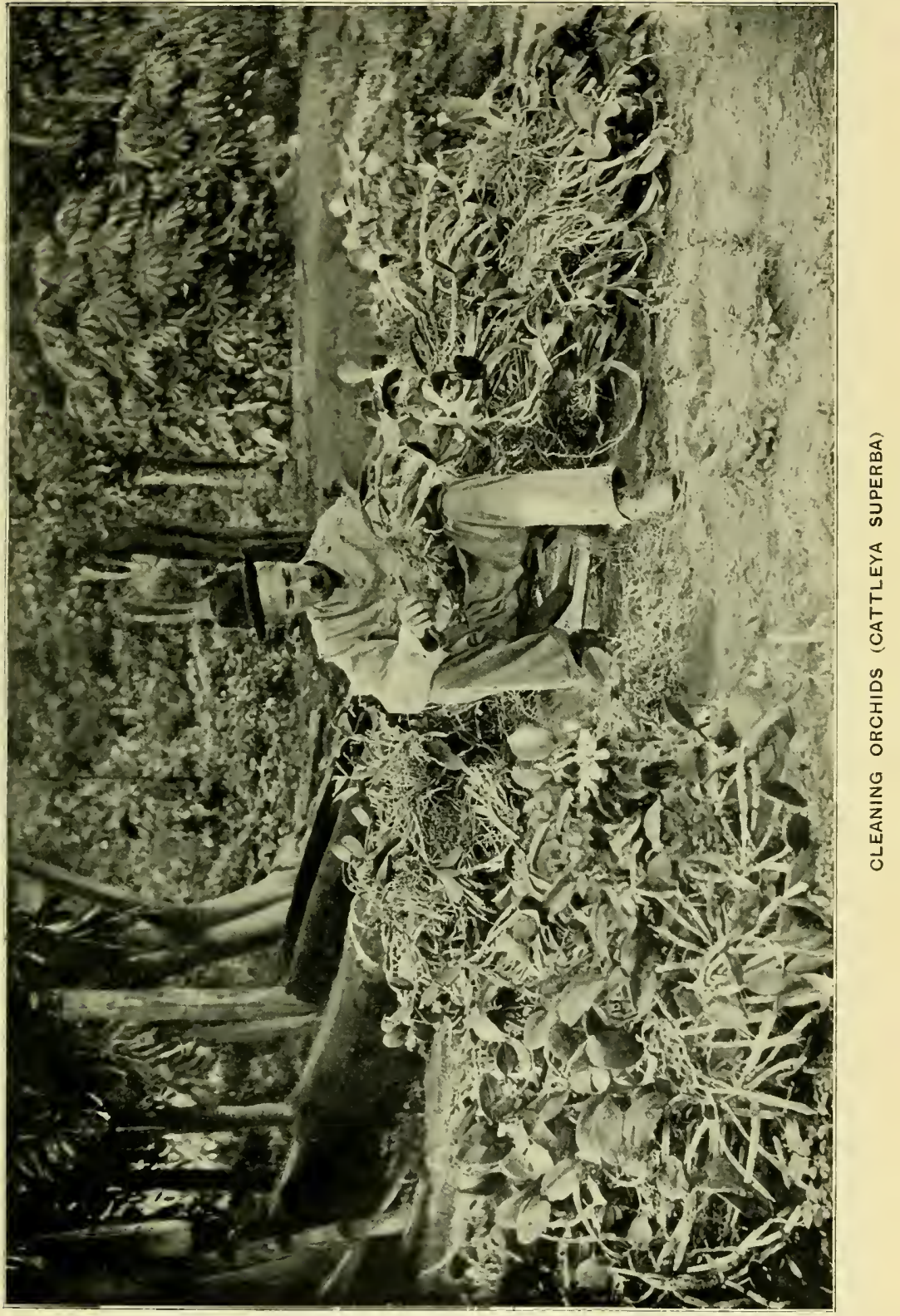



whom I had employed to cut a track to the base of Turagua returned. It had taken them nine days to perform the work. They were tired, they said, and would like a rest, so we fixed upon the morning of the 11th for our departure. The Indians came early. It was a raw drizzly morning, with heavy banks of clouds piled up towards the east and appearing to almost touch the tops of the trees. Such threatening weather denoted abundance of rain, and I knew that we would be soaked through and through before getting very far. Nevertheless I decided to start at once, for the trip had been forcibly put off so often, that it seemed at one time as if some strange fatality stood in the way of our long-contemplated journey to the mountain. No time was lost in preparing the packs. Oval frames about three feet in length, made of thick pieces of pliable creeper with strips of bark woven between, had been prepared. The articles to form the pack were placed between two of these frames, which were then securely tied together. Each pack weighed from fifty to sixty pounds, and was carried by a broad band of bark stretched across the forehead, the pack resting on the shoulders and back. 'The method of carrying loads by a broad band across the head is common to most of the American tribes. In certain parts even men and women are carried across the mountains in chairs in this manner. Throwing the body slightly forward, the carriers proceed at a jog-trot, and thus cover long distances with a considerable weight.

When we filed out of the settlement our party consisted of the three Indians, Isidor, Maite, and Sylvestre, Raoul Turban (a taxidermist), and my boy, Guy. The moment an Indian comes in contact with Venezuelans he adopts some Spanish name. Maite is a corruption of 
Mateo, and not an Indian name, as one might suppose on first hearing it. Sylvestre, who had come from one of the Waiomgomo villages on the Parime mountains only a month or so before my arrival, had been named immediately by the others. I never could induce Isidor or any of the others to tell me their Indian names. All the Indians of Guiana appear to have the same objection to divulging to strangers the names by which they are known to their immediate relations. It was about nine when we passed the last house at the edge of the clearing and entered the forest, and we agreed not to stop before reaching a place called Esperanza, where the tracks of the sarrapieros end, and the trail opened by our Indians began. By the time we got to the Laja de los Perros ${ }^{1}$ the rain had increased to a steady downpour. Near to this laja a huge slab of rock resting on two upright masses forms a natural shelter. Old Guachee, one of the La Prision sarrapieros, and his wife had taken possession of this rocky protection from the weather. They were collecting tonca-beans, for the crop was then at its height, and most of the people from the settlement were staying in the forest. We stopped at this natural rancho and had a chat with the old man and his wife. They were a dilapidated pair. In the days of his youth the man, who, I was told, had been of a turbulent disposition, had had frequent misunderstandings with his neighbours, especially on feast-days when the rum-bottle had been circulated more freely than wisely. In one of his encounters he had suffered considerable damage, not the least of which had been the loss of an eye. The woman was a victim to that curse of the Caura, ulcers on the legs. One of these ulcers had caten deep down ' 'The Rock of the Dogs.' 
into the very bones of her right ankle, and had so crippled her that she was unable to walk. In spite of her affliction, she followed her one-eyed husband for many long miles into the woods, slowly dragging herself on one leg. The sight of this couple stricken with age and disease, forced to wander about the forest so as to obtain a living, was painful in the extreme. After leaving this scene of misery we proceeded in the direction of the Laja Grande. Many ranchos had been built in the vicinity of this laja, for its size and the flatness of its surface offered great convenience for the preparation of the beans. We could hear the sarrapieros shouting to each other as we followed the narrow path through the forest. We passed three of their huts, but did not stop. The trail lay almost due east, and except where a curve had been made to avoid some obstruction, such as a fallen tree, it was straight enough. We trudged wearily along, keeping our eyes down so as to avoid being tripped up by the network of roots and creepers with which the ground was covered. Several streams, some with mud, others with sandy beds, had to be crossed. At first I took my boots off whenever we came to one of these streams, but I soon got tired of this repetition of taking off and putting on my socks and boots every ten minutes, and I resolved to leave them on until we should reach our camping-place. It was all right when the bed of the stream happened to be of mud or earth, but where it was sand, and my boots got filled with particles, I still had to take them off and wash the grit out, or I should have been unable to continue walking. At about one o'clock we halted on the banks of a broad clear stream and had something to eat. The Indians had brought ripe

\footnotetext{
3 The Great Rock.
} 
bananas, fresh cassava bread, and boiled turtle-eggs. Off these we made a hasty meal, and then continued our journey. We had got beyond the district where the sarrapieros conduct their operations. Within the memory of the people at La Prision no one had ever gone farther than the sarrapial of Esperanza, and there were no tracks beyond the spot except the newly opened trail made by our Indians. The masterly manner in which the cutting of this trail had been performed was really astonishing. In the thickness of the forest, where it was impossible to see anything fifty yards ahead, these men, without a compass or any other instruments, had succeeded in opening a road to the foot of the mountain, of which even a trained surveyor might have been proud. No deviation from an almost straight line marred the accuracy of their work. It was evident, from the quantity of game we came across, that we had got beyond the haunts of the people on the Caura. Although we were far from being a silent lot, and the men, in getting through the narrow path with their packs, made a good deal of noise, yet we surprised a number of the larger game-birds which are so difficult of approach near the settlements. These birds, so wild in the vicinity of La Prision, never having been disturbed in this locality, are quite stupid. I could have shot several curassows had we not been in a hurry to get to a good camping-place before nightfall.

It was near sunset when we stopped for the night. While Maite and my boy Guy were preparing dinnel, Isidor and Sylvestre constructed a rancho. Poles were lashed to four trees in the form of a square at a height of about eight feet. Upon these poles others were placed as rafters. A thick covering of palm-branches formed the roof. Either palm-branches or the long broad leaves of 
the wild banana are used for this purpose. Our rancho was completed in less than half an hour, and when our hammocks had been slung between the trees under the thick covering of palm-branches, the place looked quite snug with the big log-fire burning in front of it. Close to our hut one of the men, while collecting firewood, came across the fresh excrement of a full-grown jaguar. The conversation immediately turned upon tigers, as the jaguar is called all over South America, and their doings. Each man had some story to tell of the cunning and audacity of the tiger, and the speaker usually happened to be the principal figure in the story which he was telling. Isidor was an easy winner in this competition of, I am afraid to have to admit, imaginary tiger-stories. As he could speak Spanish fairly well, he not only told of his own adventures, but he interpreted the tales of his two friends, and put the finishing touches to them, so as to render them more impressive. It may appear strange that men of the same race who came from villages fairly near to each other should have been utterly unable to carry on a conversation of even a few sentences. Such, however, was the case with Maite and Sylvestre. So different were the dialects of these men, one of whom had come from the mountainous country at the sources of the Erewato, and the other from the Pacaraima range, that they could not exchange even the simplest ideas. It was amusing to observe their futile attempts to carry on a conversation when Isidor, who spoke both dialects and interpreted for them, happened to be absent.

The fact of the members of a small village consisting of but comparatively few individuals speaking a dialect peculiar to themselves is not uncommon amongst the Indians of Guiana. Probably the difficulties of com- 
munication in this country of impenetrable forest may, to a certain extent, be responsible for the existence of so great a number of dialects. The prevalence of long-standing blood-feuds between neighbouring villages may also, by the isolation which they tended to produce, have contributed to these divergencies from a common language.

As Isidor and his companions told their stories in the ruddy glow of the wood fire, using in their excitement many forcible gestures, they so impressed my boy Guy, that he got up and removed his hammock from the outer part of the rancho where he had slung it, and begged me to allow him to sleep between the Indians and myself. He was resolved that he, at least, would not be made a meal of by the jaguar, a token of whose presence in the neighbourhood we had seen on our arrival.

Towards midnight it rained heavily, and we congratulated ourselves that we were under shelter.

Isidor and Sylvestre were astir early, and woke me by their movements. They were splitting wood, with which they made a torch, while I watched them lazily from my hammock. Although it was quite dark, many curassows were calling in the forest around us, while now and again a tinamu would utter its long-drawn tremulous note. The Indians, having completed their arrangements, started out together. Isidor carried my twelve-bore, while Sylvestre went in front, holding aloft the torch they had made, which cast a bright glare around. They had not been gone many minutes when a report, followed by a thud, told me that they had succeeded in killing a curassow. After a short while they fired again. When they returned to camp they brought two Paujis. They could have shot more, they said, but why waste powder and shot when we had enough game for breakfast and 


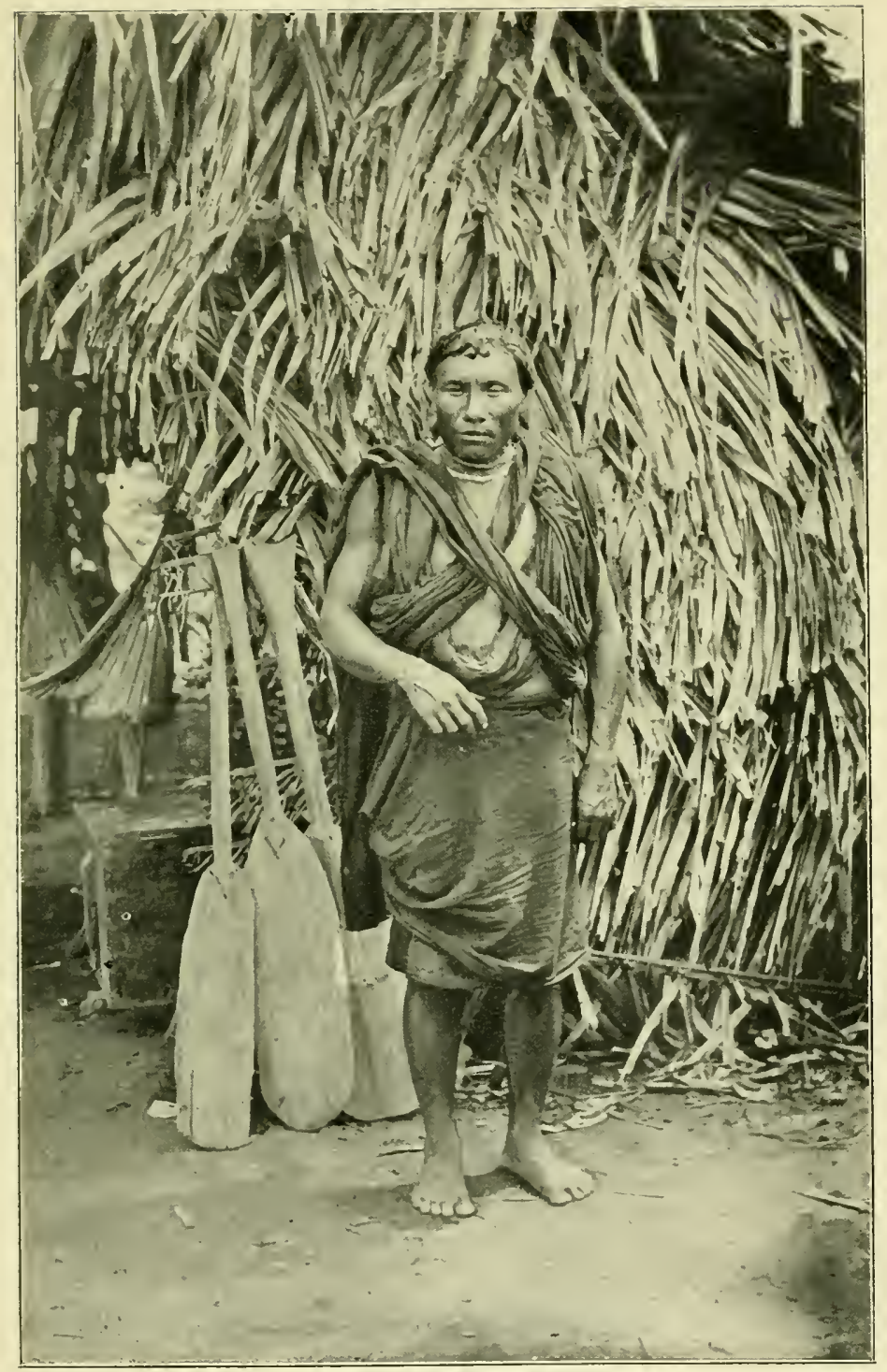



dinner? Indians are, as a rule, poor shots with a gun, yet they rarely miss. I have never seen Isidor or any of the others attempt to fire at a bird on the wing. Why should one fire at birds flying, with a chance of missing, when they can be stalked and potted with certainty at short distances? Powder and shot are commodities too valuable to be wasted in practising difficult shots. But if the Indian be but a poor marksman with a shot-gun, he more than makes up for his lack of skill by his ability as a tracker and hunter. No Indian thinks of wasting a shot until he gets to within but a few yards of his victim.

We made a hasty meal off biscuits and tea, and continued our tramp towards Turagua. The leaves of the undergrowth were dripping with water from the previous night's shower, and we were soon wet to the skin. Almost immediately after leaving our camping-place we got to a part of the forest which the Indians told me had taken them nearly two days to cut through, although I do not suppose that this belt of matted vegetation could have been more than a couple of miles wide. Of the extent of its length we were ignorant. These belts or tracts of tangled creepers and bush are called bejucales.

While getting through this bejucale I almost trod on a very large coral snake. The Indians begged me not to kill it. I was surprised at this, because these same men did not appear to have any scruples about destroying other snakes. Tortoises are abundant all over this region. The Indians captured several, which they tied with creepers to the branches of small trees by the side of the track they had cut, to be taken on their return. At La Prision these tortoises are kept in enclosures, and eaten on special occasions. During times of continued drought numbers of these reptiles are caught by the men 
and boys who wander along the banks of the streams and pools where there is water. Morocoy, as the tortoise is called in Venezuela and Trinidad, is a favourite dish when well prepared. These reptiles can remain a considerable length of time without food. The liver of the tortoise is large compared with its body, and it shrinks in proportion to the length of time during which its owner has been deprived of nourishment; and this has given rise to the belief among the people that the animal eats its liver when it is unable to obtain any other food.

During this day's march we were followed by large gnats, which gave us a good deal of trouble. So persistent were they in their efforts to bite us, that there appeared to be no other means of getting rid of them, except by allowing them to alight, when they could be killed by a sharp slap. They would keep buzzing around our heads until they could settle on some bare spot, when they would nip off a bit of skin and clear ont with their booty, to return a few moments afterwards with appetites whetted by the taste of so dainty a morsel. The Indians, who were clothed after the fashion of Adam before he got into trouble, suffered most from their attentions. Embarrassed with their packs, they found it difficult to keep off their tormentors, for they had more than their hands and faces to look after. On this occasion my naked companions must have been convinced that there was some advantage in being clothed. Considering that these Indians undertake journeys, often lasting for months, through dense thorny bush where wasps and ants are plentiful, it is marvellous to note how smooth and free from marks their skins are as a rule. How they can get through certain parts of the forest where the ground is actually littered with thorns has puzzled me. A man 
accustomed to boots who would dare to attempt such a feat would be lame before he had gone many yards. These Indians all walk with the toes slightly turned in, and they plant one foot before the other in a straight line. In cutting a track through the forest, much labour is saved if it be made narrow. But the narrower the path the more careful one has to be of the stumps and small trees on its sides. Hence the adoption by the Indians of a system of walking suited to the conditions under which they have to travel.

We ate cassava and turtle-eggs at midday, as we had done the day before. Isidor advised me to drink my fill at the stream where we then were, for we would not, he said, meet with water again until late in the afternoon. He and his companions then set the example by filling themselves up with water as only savages can do. It was necessary that we should hurry on if we meant to reach before nightfall the rancho built by the Indians when they cut the track. Isidor took the lead, with Sylvestre following, and they made the pace. As we proceeded the ground became uneven. The Indians told us that we were nearing the first hill, and that we would have to cross three of these hills before reaching the base of Turagua. The aspect of the country when we reached the foot of the hill was quite different to that which we had left behind us. In place of the luxuriant growth of the forest, we were going through a vegetation similar to that of the lajas.

In climbing these hills we had to proceed cautiously, as rocks of all sizes and shapes were piled loosely one on top of the other, and in certain cases we found that a slight touch was sufficient to displace masses of considerable weight, which would go rolling down the declivity 
to the danger of those behind. In the more open parts, patches of a tall coarse grass occurred here and there, and were a source of a good deal of inconvenience to us. The blades of this grass would cling to our faces and hands, and, if not lifted off carefully, cut us painfully when we moved away. Even our clothes suffered from the razorlike edges of this grass.

In the lower part of the valleys between the hills the vegetation again became luxuriant. We found in these hollows quantities of a fruit which in appearance and taste reminded me of the sapodilla (Sapota achras), but was somewhat smaller and more regular in size. The tree bearing this fruit is one of the tallest in the forest.

From the top of the second hill $\mathrm{I}$ obtained a good view of the cliff forming the highest point of Turagua. At the bottom of this hill we pitched our camp close to a rapid stream of beautifully clear water where the Indians had stayed when they cut the track.

The Indians went out before daybreak, as they had done the day before, and they were again successful in bringing back a couple of curassows. Turban and Guy preferred not to attempt the ascent of the mountain, so I sent them out to collect birds and butterflies. The Indians and myself then crossed the last of the three hills which run parallel to the base of the main mass. Between this hill and Turagua there is a dark narrow gorge, at the bottom of which a rivulet trickles, forming pools along its bed. We sat on some rocks near one of these pools and rested a while, for a long stiff climb lay ahead of us. The Indians drank copiously, actually filling themselves up with water, and they advised me to do likewise, as we might not, they said, be able to obtain anything to drink until our return, so they thought it wise to absorb a 
supply to last for the day. There were a good many butterflies flitting up and down over the pools formed by the rivulet, while swarms of flies kept buzzing around us, settling on our hands and faces, and even getting into our eyes.

The ascent of the slope leading to the peak was at first gradual, but by degrees it became steeper. Low down in the gorge and for some distance after leaving the stream I saw but few rocks, a thick stratum of soil having formed in the bed of the valley, and this supported a vigorous vegetation similar to that we had passed through before reaching the hills. From the tops of the tallest trees came the call-notes of the bell-birds. Judging by the frequency with which the metallic bang was uttered and replied to, this chatterer must be common in this secluded valley. The Campanero, 'the bellman,' as the natives call the bird, is rarely met with in the neighbourhood of cultivated spots. The presence of man appears distasteful to this lover of primeval forests, and if his domain be encroached upon by human beings, he immediately abandons it to retire to some distant recess, where he can enjoy the solitude he loves so well.

The higher we got the more rocks we met with, some of them being of considerable size. I noticed that the masses close to the cliffs were generally larger than those lower down, the blocks decreasing gradually in size in proportion to their distance from the main mass. These smaller rocks lower down in the valley had no doubt been also giants many ages ago when they lay at the foot of the cliffs which then formed the central mass of the mountain covering the spot where we now stood. The rains of ages had reduced their volume. Slowly but surely the rains of the future would continue the work of 
erosion, until Turagua would have wasted away to an inconspicuous hill like those we had left behind us, while those hills would have disappeared into the surrounding plain.

For a considerable distance we skirted the base of the titanic wall which forms the crest of the mountain, without being able to find any spot by which it would be possible to attempt the ascent to the plateau above. Our progress was slow, for in many places the ground was strewn with the débris brought down by the masses of rock in their descent from the cliffs. I sat down and rested while the Indians went ahead to try to find some place by which the peak might be scaled. In about an hour's time they returned. They had seen, they said, a gully which appeared to lead to the top of the mountain, but the ascent by it would be, they thought, difficult and dangerous. Isidor suggested that we should try the other side on the morrow, when we might find some spot offering easier means of access than the gully on this side. I determined, however, to see for myself what chances of success we should have in making the attempt by the gully. I found, on reaching the spot described by the Indians, that they had not exaggerated the difficulties of the ascent by this way. A narrow streak of vegetation, consisting mostly of ferns, marked where a stream had cut a shallow bed in the face of the cliff towering above us. For the first 200 or 300 feet our climb was up a surface almost upright, the deviation out of the perpendicular being so small that it only just allowed us to lie on our faces while holding on to the ferns and roots. of the plants which the moist rock supported.

Sylvestre and Maite went first, I was third, and Isidor last. These Indians are excellent climbers. Even the 
largest forest-trees did not appear to offer difficulties which they could not overcome. If the trunk of the tree they wanted to climb was of such dimensions that they could not embrace it, they would choose some other tree near by, and, passing from branch to branch like monkeys, they soon got to the place they had decided to reach.

As we proceeded we found the ascent less arduous. After the first 100 yards the gully widened out, nor was. it so precipitous as lower down. Although the incline was still steep, we were able to stand up. Many stunted trees like those of the lajas grew from between the crevices in the rocks, but everything was greener. The rocks, trunks, and branches of the trees were covered with beautiful mosses and ferns nourished by the mist which crept daily up the sides of the mountain and shrouded its summit. A stately Sobralia grew in clumps in great profusion, while in the glades we met with the same razor-grass which had caused us so much inconvenience when we crossed the three hills. The highest point of Turagua is about 6000 feet above sea-level, and consists of one huge block of granite nearly flat on top. Stunted mosscovered trees overgrown with a scandent shrub formed the vegetation of the plateau, which also supported a dense growth of bromelias. The Indians pronounced the scandent shrub to be the water-vine (Doliocarpus), and as we were exceedingly thirsty they cut pieces of from three to four feet in length, which produced a small quantity of clear water. It took quite a number of these pieces to quench our thirst.

To get through the field of bromelias overgrowing the plateau, it was necessary to cut a track through them. Closely resembling the pineapple in its growth, the leaves of this bromelia are armed with sharp spikes, and the 
plants grow in such dense masses that they form a barrier through which it would be impossible to get without the continuous use of the hunting-knife. Even after the track had been cut we had to exercise a good deal of caution in our movements. Many of the plants bore bunches of yellow fruit, of which the Indians and myself ate a good many. The pulp is white, full of small black seeds, and, although sour, is not disagreeable. I suffered for some time after from a painful itching of the lips, tongue, and palate, and whenever I spat my saliva was streaked with blood. The Indians experienced the same sensations. The fruit of the closely allied Bromelia pinguin produces similar effects when eaten.

Our track led us to the south-west, and we reached a point on the edge of the cliff from which there was a magnificent view of the country to the south and west. Standing on a rock quite close to the precipice, I looked over the ocean of trees stretching away beneath us. Towards the west was the Serrania de Mato, where the Piaroas dwell, a long range of dark blue melting away in the distant haze. Through the green of the forest we could see stretches of the Caura glistening in the glare of the afternoon sun. Isidor pointed along the river to the south in the direction of the country from which he had come many years before. It would take several weeks, he said, to get to that distant village on the Merevari mountains, where his people lived. Between us and that small tribe no human habitation existed, nothing but forest, vast and impenetrable, like that which lay beneath us. If I ever cared to go with him to the place of his birth, then he would show me mountains, he said. There was Améha, where the evil spirits dwell; and Arawa and Arichi. Those were mountains, not like the hillock we 
were standing upon, but giant masses which no human being could climb. And thus it was while I stood on the highest point of Turagua, looking towards the El Dorado of the conquistadores, the idea of exploring the region where the Caura rises took possession of me. We skirted the edge of the precipice for some distance with the intention of descending by some other route if practicable, but a dense mist had been creeping up the sides of the mountain, and we were soon enveloped in it, rendering any further exploration along the cliff impossible. It rained heavily, and we got drenched to the skin. The rain was accompanied by violent gusts of wind, which at this altitude, with our soaked clothes clinging to our bodies, made us feel somewhat chilled. As soon as the fog had cleared up, we retraced our steps through the field of bromelias to the spot where the descent began. We sat on some rocks and ate roasted pauji and cassava, which the Indians had brought tied up in wild banana leaves. The descent did not take much time, but as we had left the mountain late it was almost dark when we got within sight of our camp, which we could make out at some distance below us by the bright fire kindled by Turban and Guy. We shouted to give notice of our approach, and, hurrying on, we were soon seated within the circle of ruddy light which the burning logs cast around. Turban said that he had been out the greater part of the day, and had returned a couple of hours before us. Both he and Guy were of opinion that it would be impossible for us to remain where our camp was pitched, if we intended to stay in the neighbourhood of the mountain for a few days. On their return from hunting they had found the whole place alive with flies. Never, they said, had they seen so many flies together. The blankets 
spread out to dry, our clothes and hammocks, a couple of curassows tied to a branch, everything almost which had been left exposed, had been used by these flies for depositing their disgusting larvæ. From the moment of their arrival they had been occupied passing our things over the fire so as to rid them of the filth left by these disagreeable visitors.

Raoul had shot three curassows. We dined off these and roasted ripe bananas, and then retired to our damp hammocks. Although I was very tired I passed a bad night, as the quantity of bush-ticks I had collected on my body during our day's tramp kept me awake the greater part of the time.

At daybreak we had the usual cup of black coffee, which becomes indispensable after a time. With Maite's assistance I managed to get rid of some of the ticks with which I was covered, and I then had a good long bath so as to allay the irritation caused by the garrapatas, as ticks are called by the natives. With sunrise the flies began to arrive, and by eight o'clock they were numerous enough to be disagreeable. By the time we had finished breakfast half an hour later they were around us in swarms; it was time to think of getting away. The Indians made up their packs as hastily as they could, and we left without regret this paradise of flies. Although my naked companions were much more heavily laden than Turban, Guy, or myself, we found it difficult to keep up with them until we reached the stream which we had passed two days before. There they left us and hurried on ahead, and we did not see them again until we reached our camp late in the afternoon. It never occurred to them, considering that their track was in places difticult to follow, that we might go astray and get lost in the forest. 
Probably they expected us to possess some of that instinct for following a trail with which they were so highly gifted. On the way we surprised a flock of trumpeters, and shot three. In addition I killed two penelopes. When we were quite near to our camp it rained heavily, and although we hurried on as fast as we could, we were wet to the skin by the time we reached shelter. The Indians had not forgotten the tortoises left on the way; they were now hanging from the rafters of our rancho.

We breakfasted early. The Indians broke the shells of the tortoises with a heavy log of wood. They then picked the pieces of shell off the still quivering masses of flesh, which they wrapped up in banana leaves. After crossing the stream they hurried on as they had done the day before, and when we got to La Prision in the afternoon, I found that they had gone on to Isidor's house, probably to have a night of it, leaving word that they would return in the morning. We proceeded with caution, for had we strayed from the trail we might have got lost in the depths of this interminable forest. Gamebirds were plentiful; but I decided on not wasting time in following them up, as it would have been too fatiguing to have to carry a number of heavy birds over the distance we still had before us. Perhaps the Indians had left us to avoid having to add to their burdens. I killed only four trumpeters as specimens.

By one o'clock we reached the Laja Grande, and shortly afterwards we passed before a large rancho occupied by several people. Two of the men were breaking tonca-beans on a slab of rock, while one of the women was mending clothes and another was cooking. They asked us to stay and share their meal. Although we were all very hungry, I thought it best to refuse their 
invitation; I knew that if we once sat down we should feel more fagged on resuming our tramp. We passed another hut about a mile farther on, and reached $\mathrm{La}$ Prision late in the day, For a couple of days we were all footsore, and spent most of the time in our hammocks.

After our return from Turagua, we spent three weeks at the rapids of Mura and Piritu. Isidor brought his family with him, so that we were a large party. We collected quantities of Cattleya superba, which is abundant on the rocky islands in the river. Towards the end of May I bade adieu to my Indian friends, with the understanding that I would return at the end of the year so that we might go to Améha. 


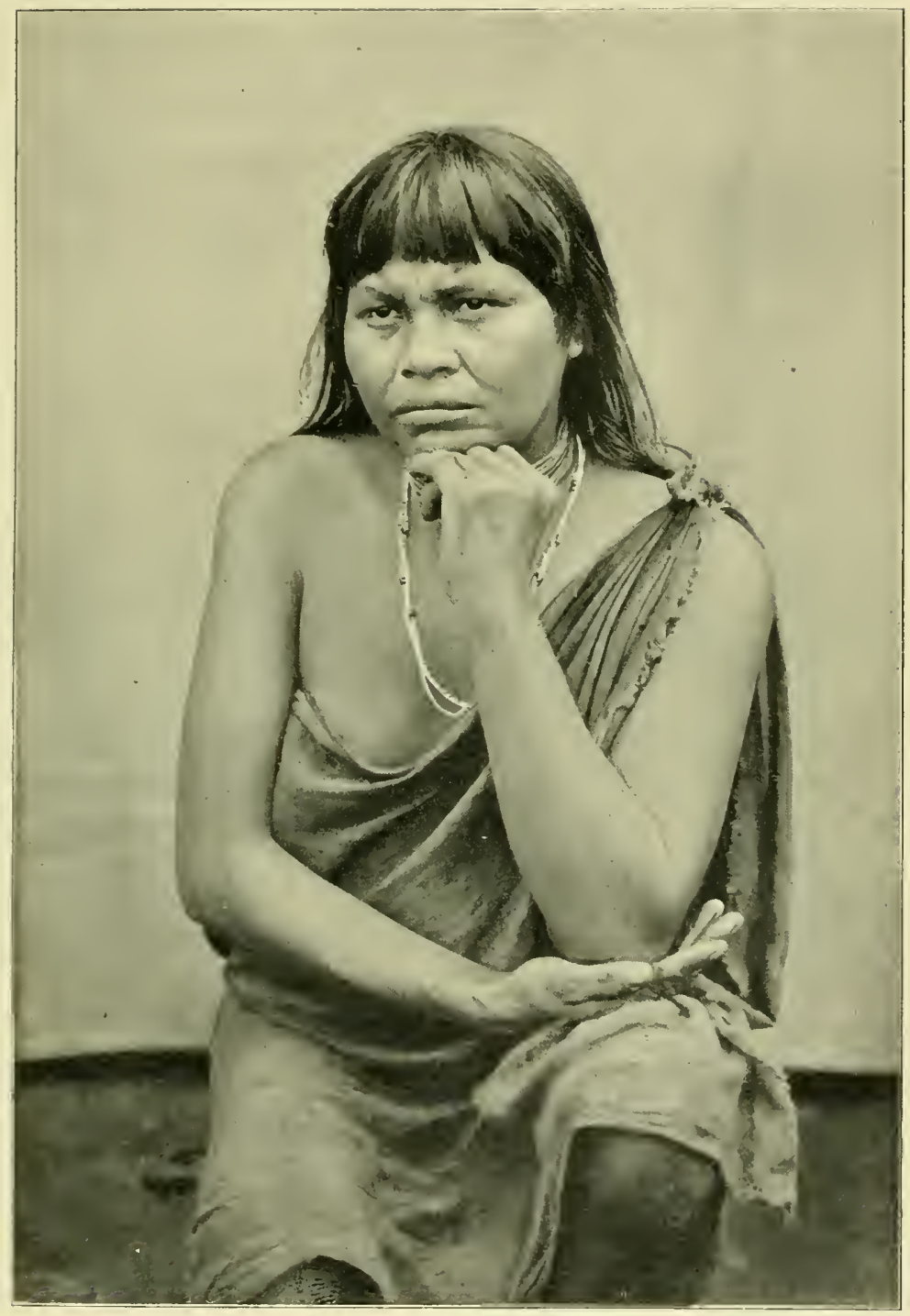

ISIDOR'S WIFE 



\section{CHAPTER III}

History of the Orinoco steamers-Seizure of the steamel' 'Bolivar'Departure from Trinidad-The hammock-Gambling on boardGnaraunos - Barrancas - Guayana la Vieja - Ralegh and Guayana la Vieja-Simon Bolivar and Los Castillos-San Felix-El Callao mine-The Caroni-Ciudad-Bolivar.

Although I had promised the Indians to return at the end of the year, circumstances over which I had no control, to use a hackneyed expression, prevented me keeping my promise. While descending the lower reaches of the Caura, after my departure from Mira, I contracted malaria of so virulent a type that for five months I did not leave my bed, and for a considerable time after I was unable to travel or to collect orchids. My long illness and inability to do any remunerative work had resulted in my having to dispose of the whole of my slender resources, so that any voyage of exploration requiring outlay was for some time an impossibility. Towards the middle of 1901, however, I had a run of luck, and began to think of the journey to Améha. At the same time Mr. Aurelio Battistini, an old schoolfellow, who was established as a merchant at Ciudad-Bolivar, paid a visit to Trinidad. During his stay we frequently discussed the possibilities of the rubber industry on the Caura, he being largely interested in a concession of a considerable tract of country on the banks of the Nichare. He suggested that I should accompany an American gentleman who would be going at the end of the year to inspect the concession on behalf of a syndicate. He agreed to place his steamer, 
the 'Caura,' at my disposal, free of charge, if I would assist in reporting on the rubber district in question, after which I would be free to continue my voyage of exploration to the headwaters of the Caura. It was definitely settled between Battistini and myself, when he left for Ciudad-Bolivar, that he would write and advise me when his steamer would be ready for the projected trip. Early in November I got a letter from him saying that I would have to be in Ciudad-Bolivar by the end of the month, or, at any rate, by December 2 or 3 .

I employed the whole of the month making preparations for the journey, and we fixed our departure for the 29th, the steamer 'Delta' of the Orinoco Trading and Shipping Company having been advertised to leave on that day.

Previous to 1860 all trade between Trinidad and Ciudad-Bolivar was conducted by schooners and sloops, which carried not only goods but passengers and mails between the two places. Some time in the early sixties Messrs. Grillet and Company ran a steamer from CiudadBolivar for their cattle trade, but she was not by any means a regular boat, as the exigencies of the traffic for which her owners used her necessitated her making frequent visits to Demerara and Cayenne. It was not until 1867 that regular steam communication between the towns of Port of Spain and Cindad-Bolivar was established by Mr. Hancox, under the protection of the American flag. The history of the line of steamers organised by this gentleman, and of the claim against the government of Venezuela which arose in connection with it, is interesting and instructive, as illustrating the ways of South American republics. In August 1871, when there was a rising of revolutionists known as 'the Blues,' the 
'Hero,' one of the steamers of Mr. Hancox's line, was. seized at Guayana la Vieja, the United States flag was hauled down, the captain imprisoned, and the steamship, used as a man-of-war and transport for troops. The revolutionists having seized the 'Hero,' the Government promptly took possession of the 'Nutrias,' deposed her captain, and against his protest manned and armed her and engaged her in a naval combat with her sister ship. the 'Hero.'

Out of this incident and others of a similar nature there arose a claim which lasted for quite a number of years before Mr. Hancox succeeded in squeezing something out of the Venezuelan government.

From the above description of the 1871 incident, it will be seen that whenever civil war breaks out in Venezuela, the rival factions vie with each other in obtaining possession of and transforming into men-of-war the steamers trading on the Orinoco, which are generally the property of foreigners. As a rule these buccaneering operations are carried out in Venezuelan waters, but in November 1888, during what was known as the Crespo revolution, an attempt was made to seize the steamer 'Bolivar' while in British waters in the harbour of Port of Spain. The following is the account given by a local paper of this daring act:

"On Saturday evening last ${ }^{1}$ the s.s. "Bolivar," which flies the Venezuelan flag and trades between this city and Ciudad-Bolivar, was about starting, the anchor having been raised, when pistol and gun shots and shouts were heard on board, and the steamer was first seen to drift and then to be heading towards the St. Vincent jetty. This created a great excitement amongst the persons who.

1 November 17, 1888. 
happened to be on the jetty, and most exaggerated rumours were at once communicated to the police-station and circulated all over the city. Acting Sergeant-Major Giblan was immediately sent to the scene with twelve men supplied with side-arms; on arriving on the wharf they found that the affray was over and all firing had ceased, and that the "Bolivar" had approached so near to the jetty that from it they were able to scramble over her side and get on board. Mr. Fitzsimons, acting Inspector-Commandant, soon followed with twenty men under arms, and Sergeants Shelton, Rock, and Lucy. They were further followed by twenty-one men under Corporal Croney, all armed. The men were provided with ten rounds of ammunition. Our readers can imagine that, with such an extraordinary display of arms, the wharf far and wide presented a scene of the wildest excitement and commotion amongst the hundreds of spectators who strove to get as near to the central spot as possible. At an early hour the "Bolivar" steamed off and anchored at a short distance from the jetty. The Hon. H. Fowler, Colonial Secretary, accompanied by the Hon. Vincent Brown, acting SolicitorGeneral, appeared on the scene and went on board the "Bolivar." Mr. Harragin, acting magistrate of Port of Spain, and Dr. C. B. Paisley also went on board. Those who were suspected of taking part in the affair were pointed out, and seven prisoners, quiclily followed by six others, were sent on shore. We have been informed that the prisoners, although accompanied by the police, were badly treated by the mob on their way to the police-station. We went there shortly afterwards to get the names of the prisoners, but found the iron entrance-gate closed and guarded by an armed police-patrol. This appeared so ridiculous that we inquired into the matter and were 
afterwards informed that this step had been taken without orders. A number of armed police were left on board the "Bolivar" for the night. The result of the affray on board the "Bolivar" "was the unfortunate wounding of two men, who were immediately conveyed to the Colonial Hospital; and the death from drowning of a third, whose body was found floating opposite Mucurapo by a fisherman, on Monday, and was recovered and conveyed to the mortuary at the hospital. The prisoners were taken to the Colonial Hospital to be seen by the two wounded men, who were considered to be in a dangerous state and whose dying testimony it was deemed prudent to take. Mr. Harragin, acting magistrate of Port of Spain, attended for the purpose, accompanied by the Hon. George Fitt, who acted as interpreter. Freitas, one of the wounded men, said that he was below deck when he heard the firing; that he went on deck, and finding that his General was attacked, went to defend him and received a wound. He did not know who shot him. He looked at the prisoners, but could not identify any of them. General Urrutia, the other individual wounded, was then asked if he recognised among the prisoners those who shot at him, and he replied, "No." He was then requested to look at them again well, when he inquired if the law compelled him to reply. He was told "Yes" and he repeated that he recognised no one. He further said that what had been done had been done by countrymen of his, and that he would not compromise them by making any declaration. That the exaggerated rumours which reached the police-station of the affair on board the "Bolivar" created a profound sensation, there is sufficient evidence from the successive bodies of armed police who were hurried to the wharf; and that the executive took a serious view of the occur- 
rence was proved by the presence on the scene of the Hon. the Colonial Secretary and the Hon. acting SolicitorGeneral. A meeting of the Executive Council, we are informed, was also immediately held, at which His Excellency the Governor presided. In addition to the armed police despatched to the wharf and left on board the "Bolivar," six armed policemen were sent to Carenage to search for men who were supposed to have escaped from the vessel, and six others were sent under the acting harbour-master to Monos, as it was rumoured that there were armed faluchos in the Gulf. These rumours proved to be entirely unfounded and false, and are a sample of exaggerated reports conveyed to the police-station and spread over the city, and that not only alarmed the Executive but deceived the general public. One of the most barefaced falsehoods propagated was that shots were aimed deliberately from the "Bolivar" at people on the jetty, and particularly at General Perez Leon, in charge of the Venezuelan Consulate here. That the affray was entirely confined to the "Bolivar," when at some distance from the jetty, is already clear from the evidence that was forthcoming against the prisoners on Monday, at the examination, a full report of which we give in another column, and to which we refer our readers. The whole of the matter is now under judicial examination and we therefore refrain for the present from comments upon it, one way or the other, or from giving currency to all the wild rumours that have been circulated in regard to the affair:'

Thirteen men, several of whom occupied very good positions in Venezuela, were charged with murder in connection with this attempted seizure of the 'Bolivar.' Although these men were remanded from week to week 
and from month to month, the police were unable to obtain such evidence as would secure a conviction. The Venezuelans who were on board on the day of the fray had made up their minds that they were going to do without British justice or interference. They had had their family quarrel. A man had been killed. Some two or three had been wounded. While the prisoners were being tried the revolution had succeeded. Those who had been injured during the encounter were unwilling that their fellow-countrymen should be the victims of a British court of justice. So they very wisely refused to recognise any of the prisoners when they were called upon to give evidence. Eventually the lucky thirteen-for who can say that thirteen is an unlucky number after this?found that they were free to depart, which they did precipitately.

In going into these details I have drawn attention to the fact that a passenger on board an Orinoco steamer may get a good deal of excitement for his passage-money, not to speak of the risk of being hit by a stray bullet.

When we boarded the steamer 'Delta' on the afternoon of the 29th (November) our party consisted of an American gentleman, Mr. Orleans Longacre, who, as I have already said, was to accompany me as far as the Nichare for the purpose of inspecting some rubber forests on the banks of that river; Mr. Jacobson (a photographer), a Mr. Villegente (a taxidermist), and five men. Two of these were expert hunters who had accompanied me on former expeditions into Venezuela and Colombia. Of the other three, one was an East Indian whom I had employed once before to collect butterflies; the other two men were strangers to me, but they were supposed to be able to make themselves generally useful. 
It was almost dark when the 'Delta' left the pier at Port of Spain, and started ploughing her way through the shallow waters of the Gulf along the shores of the island, towards the Serpent's Mouth. The 'Delta' carried a motley lot of passengers. Most of them had slung their hammocks between the stanchions supporting the upper deck upon which the pilot-house and captain's cabin are situated, and there they lay lazily awaiting the dinnerhour. All over Venezuela hammocks are largely used for sleeping. In fact, in certain places a bed is rarely seen, and for cleanliness and comfort in a tropical country, especially when the nights are hot, hammocks are undoubtedly the best sleeping-places. Besides, the native article when well made possesses the advantage of lightness and durability, while it can be rolled up into quite a small parcel, so that a man may wander about with his bed, so to speak, under his arm. It takes but a few seconds to sling this ready-made bed between trees, if one be travelling in the forest, or between the uprights of any house on the wayside where the rover may elect to spend the night. This widespread use of the hammock has been adopted from the aborigines, who still use no other sleeping-places than these hanging nets. Pulleyn, in his 'Etymological Compend,' says that the natives of Brazil used to sleep in nets composed of the rind of the hamacktree suspended between poles. Hence the sailor's hammock derived its name. The word is more probably of West Indian origin, for Columbus in the narrative of his first voyage tells us: 'A great many Indians in canoes came to the ship to-day for the purpose of bartering their cotton and hamacas or nets in which they sleep.' Strangely enough the word hamaca, although the correct word for hammock, is rarely used in Venezuela, where the 


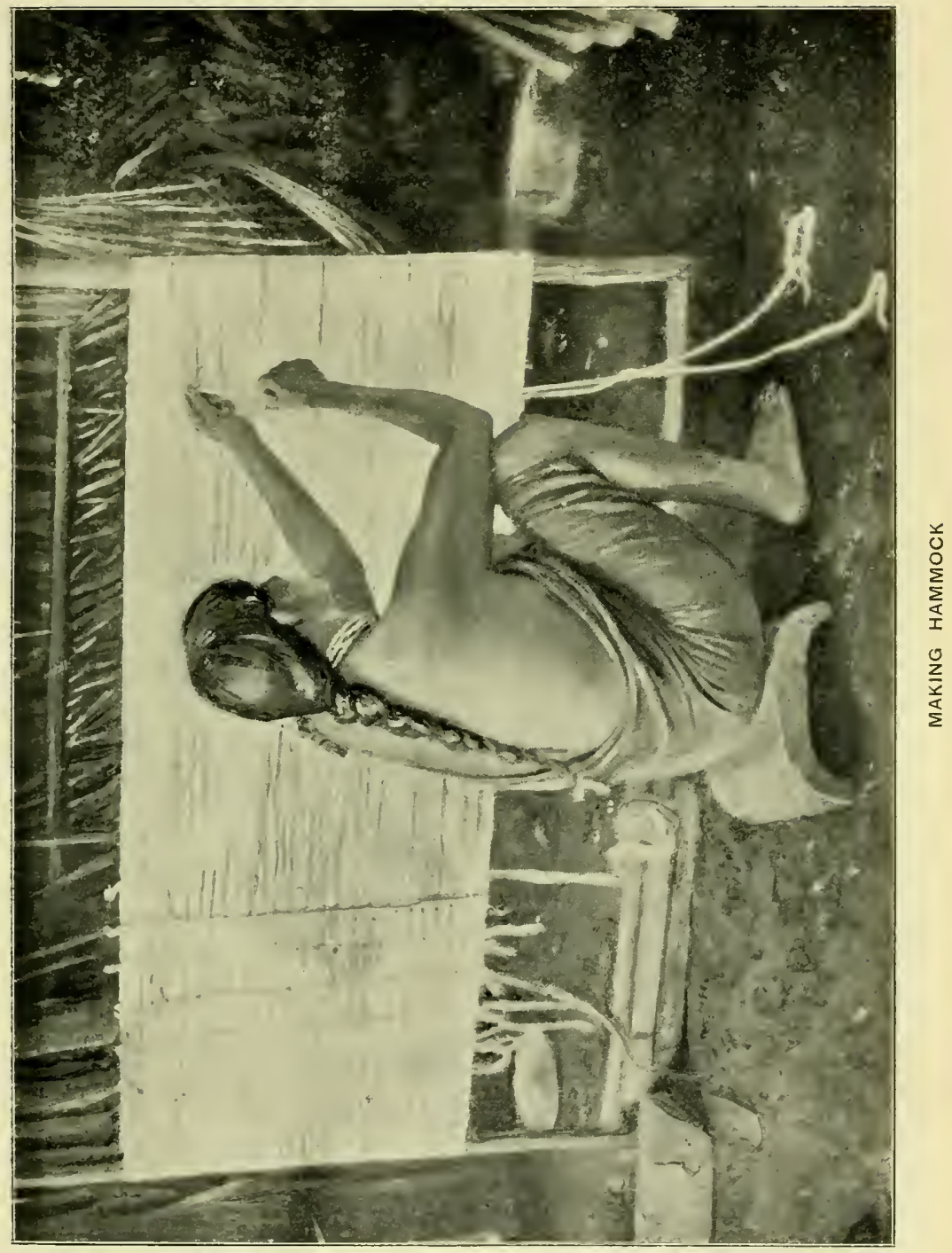



hammocks, usually made of grass or cotton twine, are called chinchorros, the real meaning of which in Spanish is fishing-nets. In the island of Margarita very good chinchorros are made of twisted cotton, but the most expensive hammocks come from the banks of the Rio. Negro, where the Indians spend many months in the manufacture of one of these articles. They are decorated with designs woven with the gorgeous feathers of rare birds into the fine grass used in this industry. The hammocks made by the Indians of Guiana for their own use are small, the net itself being rarely more than four feet and a half in length. In their wanderings, when they carry all their belongings with them, these people find it convenient to have only the lightest and smallest of hammocks.

By the time we had slung our hammocks and made ourselves comfortable it was dinner-time. Dinner on board of a steamer such as the 'Delta' is not a very elaborate affair, although the present owners of the line have made great improvements in this respect, as well as in everything else connected with the working of their steamers.

Afte: dinner the table was cleared, and several of the passengers engaged in a game of baccarat. A few played poker. I did not see any large sums change hands on this occasion, but there have been times, particularly in the eighties, during the boom in the Yuruari mines, when huge amounts were won and lost in the course of the sixty or seventy hours occupied in reaching Ciudad-Bolivar. Old gamblers recall with regret those golden days, when piles of the yellow metal lay heaped upon the table before the lucky players. At an early hour I retired to my hammock in the bow of the 
steamer, leaving the players trying their best to ruin each other in a small way.

When I awoke at daybreak on the following morning, we were already in the Macareo, one of the many channels which form a labyrinth through the low-lying lands known as the delta of the Orinoco. The scenery on the banks of these channels, or caños, is dreary and monotonous. To the waste of mangroves which line the coast, trees of more robust growth and more varied in character succeed; nevertheless, the unbroken stretch of tangled vegetation along the banks of the caños produces a feeling of weariness and a longing for a glimpse of more open and uneven country.

In this wilderness of land and water countless numbers of marsh-birds have made a home. Flocks of the scarlet ibis and snowy egret, and of that strange example of arrested evolution in bird life, the hoatzin, rise from the trees at every moment, as the steamer brushes past the wooded banks avoiding the full force of the current in mid-stream. We passed several canoes and many settlements of almost nude Guaraunos. ${ }^{1}$ Whenever we neared a settlement the Indians would put off in their dug-outs and paddle frantically towards the steamer. Biscuits and other trifles were thrown to them by the captain and passengers, and it was amusing to observe the eagerness with which they paddled for such objects as had fallen in the water; in return they threw cassava and game on board. It is a curious fact that, since the advent of the white man, the Guaraunos do not appear to have decreased in the same proportion as the other Indian tribes of Venezuela, although they are certainly inferior, physically and intellectually, to most of the

I Pronounced Waraunos. 


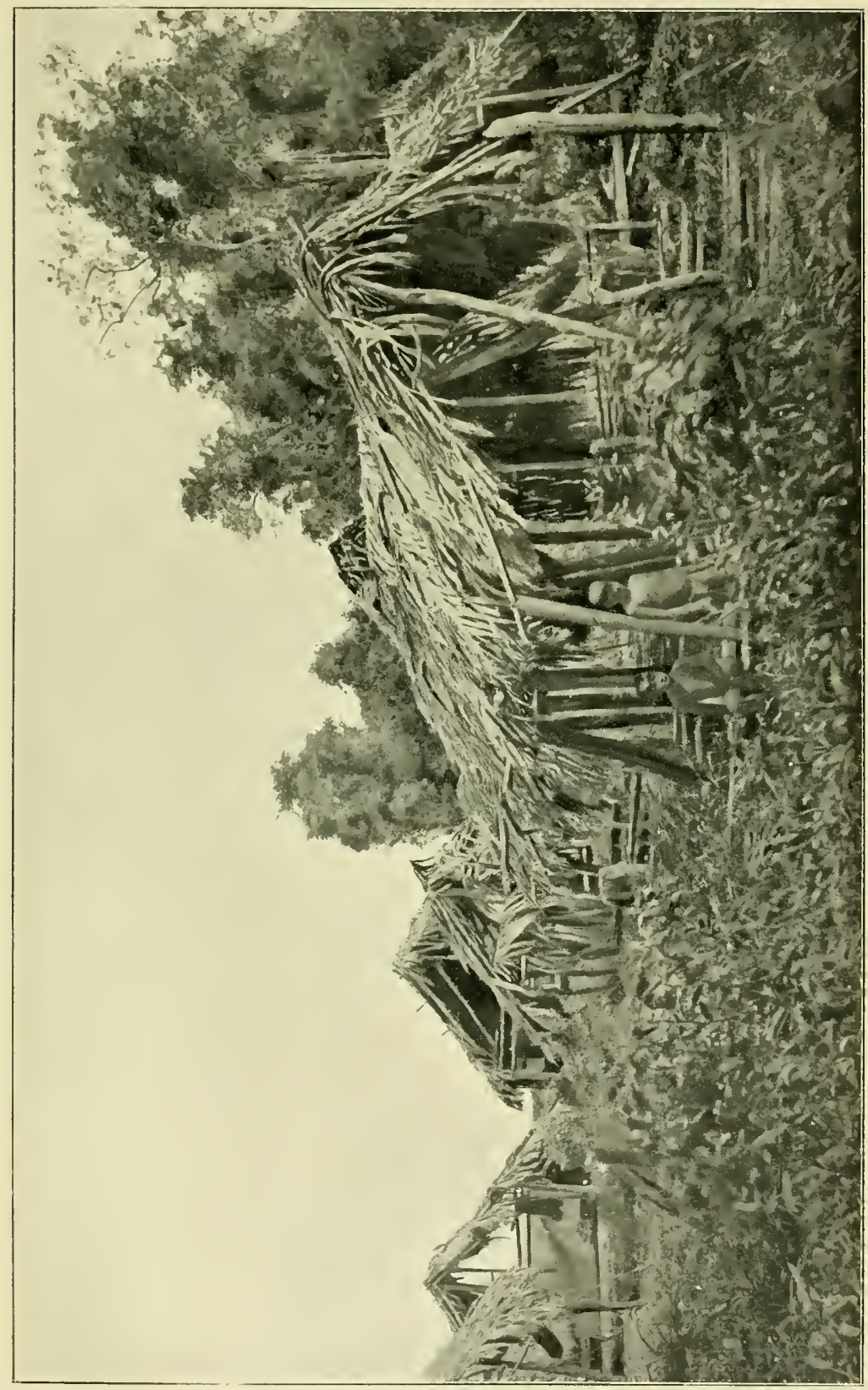

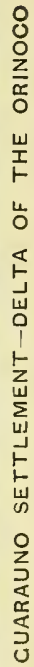



aborigines of this part of South America. While many of the most powerful tribes have almost entirely disappeared, these degraded Indians have succeeded in holding their own, in spite of the unhealthiness of the country where they live. Probably the isolation they have been able to enjoy in this waste of mosquito-infested swamp, where no other human beings would care to reside, has been the cause of their escape from extinction.

On the morning of the 30 th we entered the Orinoco itself, and shortly afterwards stopped at Barrancas, where a couple of hours were spent in repairing one of the boiler-tubes, which had given out a few minutes before we cast anchor. The wretched appearance of these small towns on the banks of the Orinoco is a striking example of the effects of misrule, which appear to have accompanied the Spaniards wherever they planted colonies; it is really painful to consider that these wretched collections of mud huts covered with thatch are the centres of immense expanses of country capable of sustaining innumerable herds of cattle. Barrancas is advantageously situated in open undulating prairiecountry, at some little distance above that extensive tract of swamp-forest through which the Orinoco discharges its waters by a multitude of channels, a short description of which I have just given. It is considered a place of some importance by those cattle-loving patriots who make a business of revolutions. To these people Barrancas is interesting, not so much from a strategic point of view, but because it is possible in its neighbourhood to lift a horse or lasso a cow without much waste of energy, if the owners be not in a position to defend their property. Barrancas has, in conse- 
quence, been the scene of many a bloody encounter between the generals of the president in esse and the one in posse, who find it profitable to make their followers fight for other people's animals. Sometimes the generals of the opposing factions are friends. In such cases the animals are divided without any fighting taking place; then one side goes over to the other, and the generals, the colonels, and the soldiers feast on beef that has cost them nothing.

Although there were passengers on board for this place they were not allowed to land, Barrancas not being a puerto habilitado-that is, a port regularly constituted for receiving or despatching vessels trading with foreign countries. The government of Venezuela, with its fatal predilection for putting every difficulty in the way of the commerce and advancement of the country, has decreed that Ciudad-Bolivar shall be the only puerto habilitado on the Orinoco. When we reflect on the waste of time and money which this arbitrary decree entails on the people of Barrancas, Los Castillos, San Felix, and on all the inhabitants of that immense stretch of country on the banks of the Orinoco east of Ciudad-Bolivar, we cannot help being struck by the lack of foresight on the part of a government which treats its subjects in so cruel a manner. During our short stay opposite this ill-used port, the 'Delta' was invaded by clouds of sandflies. We were all glad when the tinkering of the boiler-tubes was completed and we were able to resume our journey.

At ten o'clock we reached Los Castillos, formerly known as Guayana la Vieja. We cast anchor quite close to the shore, and as the upper deck of the steamer near the pilot-house commanded a good view of the old Spanish fort, I got Jacobson to talie a photograph of the 
place. Somewhere in the vicinity of this rugged hill covered with boulders, had taken place on January 1, 1618, that fatal encounter between the Spaniards and Keymis in which young Ralegh lost his life. Edwards, in his 'Life of Sir Walter Ralegh,' says that 'it was about eleven o'clock on New Year's morning that the English vessels hove in sight of Point Araya. They were still far from the chosen landing-place, but the soldiers were landed before sunset. They were, says Ralegh, as weak men as ever followed valiant leaders; yet there were amongst them some twenty or thirty very adventurous gentlemen, and of singular courage. He particularises several, and amongst them one who bore the illustrious name of John Hampden. Knevitt, Hammond, and Plessington are also named with special commendation. Part of the Spanish force already occupied an ambuscade on some rising ground in advance of the village. These men were under a certain Geronimo de Grados.

'The Englishmen had neither the design nor the expectation of an immediate encounter. Their plan was to encamp on the river's bank for the night, and to prosecute the attempt on the following morning, leaving part of the force to protect the ships and to watch the town. Grados attacked them soon after nightfall and took them by surprise. 'The common sort,' says Ralegh, 'were so amazed, as had not the captains and some other valiant gentlemen made a head and encouraged the rest, they had all been broken and cut to pieces.'

Suddenness of attack and knowledge of the ground were the only advantages which the Spaniards possessed. Whatever the inferiority of the 'common sort' of Englishmen here present, they had pluck enough to fight when rightly led. And on this occasion they were led 
nobly. Walter Ralegh, in particular, showed that his mettle was worthy of his strain.

Grados and his Spaniards, too, fought well against superior numbers. But they were driven fiercely back, and, as they retreated, the Englishmen followed. It is apparent, alike from the English accounts and from the Spanish, that Ralegh's men were as ignorant of the close proximity of the village as of the nature of the ground and of the defences. As the Spaniards under Grados came near to their comrades already under arms within St. Thomas, and headed by Diego Palomeque, the Governor, the pursuers were for a moment checked by new and fresh opponents. The English musheteers were behind, the pikemen were in advance.

Young Ralegh was the first to rally his men under the unexpected charge of Palomeque. Calling cheerily to the pikemen not to wait for the musketeers, he dashed on at their head. It is probable, but not quite certain, that Palomeque himself fell under his hand. There is no doubt that he killed a principal leader of the Spaniards who had sallied out from St. Thomas. John Plessington, his lieutenant, slew another. One of the men of Walter's own company-'John of Morocco' by designation-slew two other Spaniards in quick succession. In the mêlée young Ralegh received a musket-shot, but, bleeding as he was, he pressed on vigorously, sword in hand, and struck at a Spaniard named Erinetta who defended himself with the butt-end of his musket. Ralegh was felled to the ground, mortally wounded, but quite undismayed. He had breath but for very few words. The last words that were audible from his lips were these: 'Go on! May the Lord have mercy upon me and prosper your enterprise.' 
So died, in an obscure ambush laid by foemen who were far from being 'worthy of his steel,' all that was mortal of young Ralegh. He had shown, more than once before, his fiery temper and his utter contempt of personal danger. He had also shown not a little of firm endurance and persistency. Whatever seed of still finer qualities to come may have laid within him had lacked time to grow. A few incidents of youthful turbulence and of soldierly valour, and an anecdote or two which show that he had before him the prospect of a somewhat ambitious alliance, make up the story of his short life. He had barely reached twenty-three years of age when he fell at St. Thomas under the musket of the Spaniard Erinetta.

'Young Ralegh had fallen in the moment of apparent victory, when the Spaniards were rapidly retreating before the vigorous onset of the Englishmen. Erinetta, by whose hand he died, fell almost instantly. Part of the defeated troops took refuge in a convent called the monastery of St. Francis, at the opposite end of the village. But the soldiers under George Ralegh and Keymis quickly stormed it. Their surviving enemies took flight: first towards the nearest forest, and eventually to the place to which the women, the invalids, and children had been already taken; for all these had left St. Thomas before the attack made by the Spaniards on the English camp. That the Spanish Governor had fallen in the onset at the entrance of the village the Englishmen learnt from the Spanish priest at St. Thomas, too ill to join in the retreat, who identified his body. Two other Spanish officers had fallen. The priest was protected and cared for, but it was his ill-fortune to be forgotten in the hurry of the English departure. 
'Thus quickly had the tables been turned upon the assaulting Spaniards. But the remnant, though in disorder, were not wholly disorganised. Garcia de Aguilar, who had succeeded Palomeque in the command, displayed very soldierly qualities. He seems to have done all that was feasible under the circumstances. One of his first acts after the retreat was to send Geronimo de Grados to remove the women and sick people from their original place of refuge to (as it seems) an island in the Orinoco, called La Ceyva or Seiba. His next act was to form, from amongst the valid inhabitants of St. Thomas, two small troops charged with two special duties. They were to watch for opportunities of killing such Englishmen as should leave the village in foraging parties. They were to watch still more zealously for the prevention as much as might be of the intercourse between the English and the natives. If any Indians could not be kept away from the foreigners by terror, they were, if possible, to be shot. Others on whom the Spaniards could rely were made part of the force for defending the camp at Seiba, and for making ambuscades, whenever opportunity offered.

'Meanwhile, all the English soldiers were assembled under arms for Walter Ralegh's burial. With reversed muskets, trailed pikes, and muffled drums, but with banners outspread, the youth who had died so gallantly, and in whose grave so many hopes were to be buried, went to his rest. He was laid near the high altar in the church of St. Thomas. Captain Cosmer, who had fallen nearly at the same time, was laid near him. For three other of their dead companions-in-arms graves were made within the nave of the church.'

We have no reliable record of the time during which 
the English remained at St. Thomas. It would appear, if we are to believe Father Simon's report, that the occupation of the place extended over twenty-five days. Of the failure of Keymis to find the mine, the real object of the expedition, of his suicide after his interview with the admiral, of the imprisonment and subsequent execution of Sir Walter Ralegh because of the encounter at St. Thomas, I do not believe it would be within the scope of this narrative to give the details. On account of a fray on that worthless arid bit of country which lay before us, one of the greatest of all Englishmen was beheaded, a man who was as great in intellect as James was small, who was as brave as his king was cowardly.

But it is not only in connection with English history that Los Castillos lays claim to have been a place of importance in the past, for it is said that at a critical moment during the war of independence, Simon Bolivar was nearly captured in its vicinity; he only escaped by hiding in the swamp adjoining the town. Had this remarkable man been taken prisoner by the troops of Spain how different might have been the termination of that war which secured the independence of the Spanish colonies in South America!

Several passengers suffering from a form of malignant fever were taken on board at Los Castillos. Some appeared to be in a dying condition, and those were placed. on blankets on the deck. No account was taken of the fact that the fever might have been of a contagious nature. One would believe that this place as seen from the steamer ought to be anything but unhealthy, but I was told that an extensive swamp behind the hill is the cause of the fever from which the inhabitants suffer, and that at 
times such as the present, the diserse becomes epidemic and is the cause of many deaths.

At four in the afternoon we anchored off San Felix, also called Las Tablas. Like most of the towns on the Orinoco this is a straggling ill-kept place. One looks in vain for some vestige of the wealth which passed through it during those prosperous days when the Callao yielded its millions, and when it was believed that the numerous mines in the interior would produce even vaster quantities of the metal we adore than had ever been obtained from the goldfields of California and Australia. With the exception of the Callao none of the mines of the Yuruari district has verified those expectations of great mineral wealth attributed to the region, although it would be quite possible, under a different government and with cheaper means of transport, to work many of these abandoned mines profitably. The history of the Callao is the history of many a mining enterprise of the kind. So far back as 1860 some adventurous Americans succeeded in obtaining gold in paying quantities by washing the alluvial gravels of the streams of what was then known as the Caratal district. It was not until early in the seventies, however, that any attempt at quartz-mining was made, when a small company formed for that purpose started operations in the development of what subsequently became the famous Callao mine. As frequently happens in such enterprises, the men who made the biggest fortunes out of the mine did so in spite of themselves. Three of these men whom I knew personally admitted to me that they became holders of shares by force of circumstances, and kept them because it was impossible to get rid of them at any sacrifice. They were small shopkeepers whose sole ambition in life 


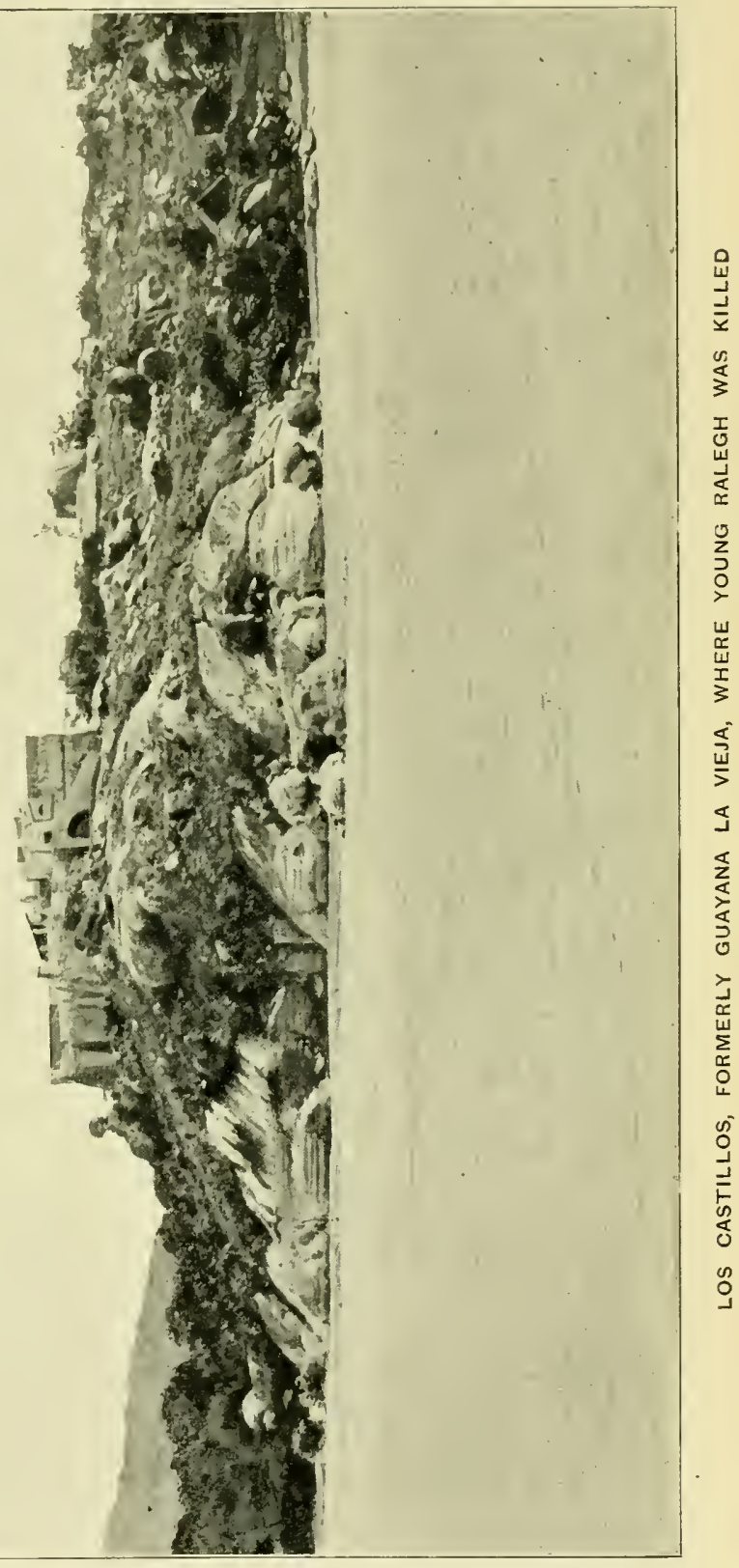



was to arrive at a competence by supplying the wants of the labourers employed in the mine. It turned out, however, after a time, that the company having exhausted its small capital was unable to pay its employés in cash, so scrip was issued to them redeemable in shares. Most of this scrip found its way into the hands of the shopkeepers, to whom those in the employ of the company were indebted. We can form an idea of the little value placed upon this scrip at the time when we learn that shares issued at 1,000 pesos could not find purchasers even at 100 pesos. One of the holders of this scrip, a negro who had been a boatman in Trinidad, related to me how he became a millionaire in spite of himself. 'I used to keep a coolishop,' 2 he told me, ' and I gave credit freely to the men employed by the Callao Company. When the mine shut down, I was forced to accept in payment of what was due to me, the scrip issued by the company to its employés. How well do I remember my journey to Ciudad-Bolivar when I offered my principal creditor all the scrip I possessed if he would give me a receipt in full for my account, amounting to about 3,000 dollars! You are an honest man, Mr. — told me. Continue working. Some day if you make money you will pay me, but I don't want "to have anything to do with that rotten paper you have brought with you." Six months after I was worth half a million.' In those days candles were used by the miners in the galleries. One small merchant had monopolised the supply of candles, and he, also, was forced to accept, much against his will, a quantity of scrip in payment of his account. Within a few months after he had looked upon himself as a ruined man he

\footnotetext{
1800 dollars U.S. money. $\quad 21$ cheap restaurant.
} 
had become a millionaire. A friend of mine now living in Trinidad relates how three original shares were offered to him when he was in business at Ciudad-Bolivar in exchange for ten cases of Angostura bitters, an offer which, he says pathetically, 'I declined with thanks.'

Two of these same shares realised subsequently 80,000 pesos. ${ }^{1}$ For a considerable period original shares of 1,000 pesos produced dividends of 72,000 pesos yearly. In those days of its prosperity the business of the Callao Company was conducted in a most extravagant manner, and although there was a clause in the articles of association providing for the establishment of a reserve fund, no such fund was put aside. When, in 1895 or 1896 , the main lode was lost, the directors of the company found it in consequence impossible to prosecute a search for the vein of paying quartz, which seems to have disappeared suddenly. The mine is now the property of a small syndicate of merchants at Ciudad-Bolivar, and they have arranged, so one of them told me quite recently, with the aid of a powerful company in Paris, to spend a considerable sum in search of the lost lode. Should the attempt be successful, and it is to be hoped that it will be, the Callao will again pour forth a stream of wealth like that which so benefited in the past the commerce of the Lower Orinoco. To the fact of huge fortunes having been occasionally made by a few lucky ones out of successful mines like the Callao can be traced that infatuation most human beings appear to suffer from, of investing, sometimes all their savings, in gold-mining speculations. And it may be remarked that men who are exceedingly cautious in their regular dealings are frequently the most easily duped where mines are concerned. Probably ventures appealing strongly to

${ }^{1}$ 64,000 dollars U.S. money. 
the gambling instinct in our natures tend to develop a feeling of recklessness inseparable from enterprises in which the element of chance is dominant. What better material to work upon could the unscrupulous and clever promoter desire than the average mortal thirsting for riches which he is eager to obtain without toil? For a number of years I was on fairly intimate terms with one of the fraternity who deal in imaginary gold-mines. He was a very able man in his way, and a marvellous judge of character. To a select few on rare occasions he would confide the results of his researches in the form of maxims such as these: "The richest of all mines, the best paying of all lodes, is the credulity of the human race.' 'Never put your money in gold-mines,' he used to say, 'let other people put theirs ; but you may put your brains.' I had almost forgotten to mention that we remained excellent friends, because I never had any money to pit against his brains.

The little that remains of the trade with El Callao and the few mines around is still done through San Felix. Heavy goods and machinery are transported by waggons ; lighter articles are carried by pack animals. The traffic over the wretched road to the mines is, in consequence, tedious and expensive, and this precludes the working of many mines which, with cheaper means of transport, might be made to pay handsomely. Where we lay at anchor we could distinguish between the dark waters of the Caroni, sweeping along the shore, and the dirty yellow wash of the Orinoco itself. The two streams flow side by side for some distance before the smaller one is finally. absorbed by the other.

When we passed the mouth of the Caroni I was again reminded of Sir Walter Ralegh's voyage up the Orinoco. 
This appears to have been the farthest point reached by him, and he describes how, when he ran to the tops of the first hills of the plains adjoining the river, he beheld ' that wonderful breach of waters which ran down Caroli ;' and how from the mountain he saw the river as it ran in three parts above twenty miles off; 'and there appeared some ten or twelve overfalls in sight, every one as high over the other as a church tower, which fell with that fury that the rebound of waters made it seem as if it had been all covered over with a great shower of rain.' $\mathrm{He}$ says he never saw a more beautiful country, nor more lively prospects; ' hills so raised here and there, over the valleys; the rivers winding into divers branches; the plains adjoining, all fair green grass, without bush or stubble; the ground of hard sand easy to march on, either for horse or foot; the deer crossing on every path ; the birds, towards evening, singing on every tree with a thousand several tunes; cranes and herons, of white, crimson, and carnation, perching on the river's side; the air fresh, with a gentle easterly wind; and every stone that we stooped to take up promising either gold or silver by his complexion.' Above San Felix the Orinoco is of imposing width, and the country on its banks is of undulating character and park-like in appearance, but thinly peopled. All night long the 'Delta' forced her' way up against the strong yellow current. At ten in the morning we sighted the hill on which Ciudad-Bolivar stands, and we were soon near enough to distinguish the churches and red-roofed houses which form the town. 


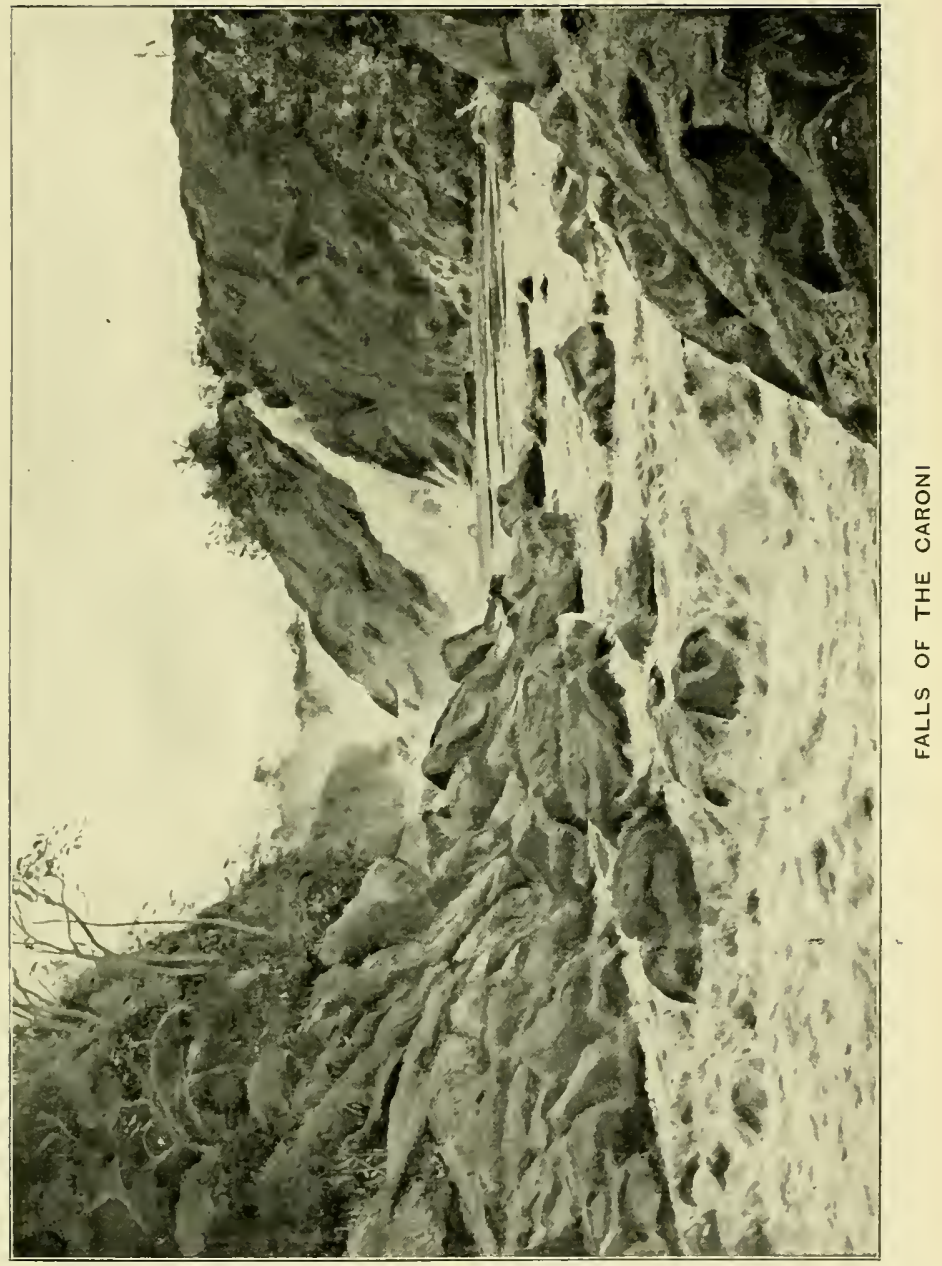





\section{CHAPTER IV}

Ciudad-Bolivar-Construction of the houses-Malaria-Notes on the town-Navigation of the Orinoco-Rise and fall of the OrinocoThe Orinoco as a highway-Exports-The trade in feathers-The trade in balata gum-Export duties-Salt-pans-Salt monopoly-ArayaFormation of salt deposits-Smuggling of salt-Leprosy-Strange method of fishing.

The first capital of Guayana was called San Tomas de Guayana. It was founded in 1575 , but in 1591 a new site was chosen, which continued to be the metropolis until 1764, when the seat of government was removed to the spot which it still occupies. The new town was appropriately christened Angostura, 'The Narrows,' because at this spot the Orinoco is contracted to a considerable extent by the hills on both banks. The distance across the river to the small town of Soledad on the opposite bank is about a mile. Above and below 'The Narrows' the Orinoco is rarely less than two miles in width, while for long stretches it spreads out to a breadth of four and even five miles, and is altogether a stream of majestic proportions. But it does not by any means occupy that position among the rivers of the world assigned to it by most Venezuelans and many travellers I have met with. It would not figure on a list enumerating the earth's twelve greatest rivers, for instance. Of course it is almost impossible to compare rivers in different countries affected by different climates, therefore the compiling of an accurate list of the most important rivers of the world in order of magnitude would be beset with 
difficulties. One may, however, obtain a fair idea of the Orinoco by contrasting it with some of the rivers of the South American system to which it belongs. Leaving out of consideration the Amazon itself, the drainage of which has been estimated to be about six times that of the Orinoco, it will be remarked that one of its tributaries, the Madeira, is at least as large as the Orinoco, and the volume of its next important affluent, the Rio Negro, is probably not less than that of the giant stream of Venezuela. The Orinoco is somewhat larger than the Tocantins, but is smaller than the La Plata. I have entered into these details respecting the river on which the capital of Guiana stands because they may prove interesting to those who, like myself, are fond of physical geography.

The name Angostura appears so appropriate to the locality upon which the city we were about to visit has been built, that it seems a pity to have changed it to that of Ciudad-Bolivar, however disposed we may be to admit the claim of the Libertador to the distinction conferred on his memory at the meeting of the Congress in $1819 .^{1}$

It took some time to get the 'Delta' alongside of the steep sandy bank which forms the landing-place when the river has begun to fall. While my men were looking after the carrying of our effects to the Custom-house, I went ashore to pay a visit to the Hendersons, one of whom is United States Consul. The first thing that strikes the traveller coming from Port of Spain when he lands at Ciudad-Bolivar, is the great difference in appearance and construction between the houses in the British West India islands and those of the towns in Venezuela.

' In 1819, at a meeting of Congress, the city of Angostura was christened anew Ciudad-Bolivar in honour of Simon Bolivar. 
After having dwelt in a house surrounded by a garden, with open galleries on all sides, and the flimsiest of jalousied windows, one feels instinctively, on seeing for the first time the squares of solid walls forming the blocks of buildings, each house with its single doorway and its heavily barred windows, that he is visiting a land of lawlessness and violence. And yet the origin of these iron-barred windows is not connected with the idea of resisting an assault or of being a means of protection during a riot, however useful such defences may be in times of disturbance now. The style of architecture adopted all over Spanish-America, from Mexico in the north to Chili and Argentina in the south, is essentially Moorish. In the heavily barred windows and the single entrance to the patio ${ }^{1}$ we are in the presence of a system of construction which answered the Mohammedan purpose of secluding and keeping strict watch over the women of the household. The Spanish-American has retained the barred windows and the single entrance, but his womenfolk sit by the hour at their windows chatting with the young men who pay informal calls in this manner. We can imagine the scene that would take place in any Moorish family if one of the ladies showed herself at the window even for a few minutes. I was still musing on the hold that customs once adopted continue to exert on a people long after the reasons for them have ceased to exist, when I reached the counting-house of the Hendersons. Jesse, the younger, had gone to New York ; the elder brother, Robert, insisted on my putting-up with him during my stay at Ciudad-Bolivar. After lunch we went to the Custom-house, as I was desirous of having my things passed through so that we might repack and

1 An open courtyard, usually planted with shrubs and flowering plants. 
prepare for our journey as quickly as possible. I was very agreeably disappointed, if I may so express myself, at the courtesy and consideration shown me by the Administrador de Aduana, G' General Barroeta Briceno, whom I found to be an affable and enlightened gentleman. As a rule, getting through a Venezuelan Custom-house is a trying ordeal, and when one is accompanied by such a miscellaneous collection of baggage as is required for a long expedition like the one I had in view, the collector of Customs can give the traveller a great deal of trouble before he finishes with him. On the present occasion, however, I had no difficulty, as I have just remarked, in getting my baggage through, so that I was able to devote a part of the afternoon to strolling through the town, while my men attended to the transport of our trunks and boxes to the Hendersons' store. Ciudad-Bolivar is situated on the right bank of the Orinoco, at a distance of 240 miles from its mouth. Its altitude above sea-level is inconsiderable, its mean average temperature about $80^{\circ}$, and its population nearly 9,000. The town itself is built on a hill, to the east of which lies an extensive lagoon. To those who associate expanses of stagnant water reeking with decaying vegetable matter with certain diseases such as malaria, it comes as a surprise to find that CiudadBolivar is a fairly healthy town. This fact is worth mentioning because swamps appear, in different localities, to have widely different effects on the healthiness or unhealthiness of the districts in their vicinity. Why, for instance, should the inhabitants of Los Castillos be subject to a deadly form of malaria while those of CindadBolivar enjoy immunity from that disease? Both are situated on sandy arid hills, both have lagoons towards 
the east over which the prevailing winds blow before reaching the towns.

If swamps or expanses of stagnant water were injurious to health in themselves, we should find it impossible to account for such an anomaly as that presented by the towns I have just described. If, on the other hand, we accept the theory that many diseases are propagated by insect agency, as has been proved beyond the shadow of a doubt in the case of malarial and yellow fevers, we can understand how it may happen that diseases dependent on insect agency for their transmission will be prevalent in the neighbourhood of one marsh and unknown in the vicinity of another. Different causes may contribute to this. In the first place, it is quite possible that the particular insect capable of harbouring some special parasite causing disease in man during certain phases of its existence may be abundant in a locality without affecting the health of the inhabitants; and this would be the case where the insects themselves happen to be free from infection through the non-existence in the country frequented by them of the organisms constituting at some period in their lives the parasites to which these insects are liable. Again, the organism may be present and the insect absent. To account for a regular malarial district both the insect and its parasite must occur together, and the conditions must be favourable to both. Nothing is more puzzling to the naturalist at times than to try to determine why some particular form of life should be abundant in one locality and absent in another, while nearly allied forms may be common to both. Causes which we are frequently unable to appreciate, but which must be very potent in themselves, are responsible for this, to us, unaccountable distribution of life; and when we speak of 
life, we must not forget that closely connected with the distribution of life is the distribution of disease and death, for what is disease and death to one animal may mean life to myriads of organisms each of which is fighting for its own welfare at the cost of the subject it is preying upon. Much has been done in recent years in connection with these terrible diseases due to the introduction into our systems of forms of life detrimental to our well-being or fatal to our existence. Much remains to be done, particularly in the study of those malarial fevers which render so large a part of the tropics uninhabitable. Theoretically Ciudad-Bolivar ought to be a deadly spot; in reality it is not. The poorer houses are built on the very edge of the swamp, and as the people entertain that bold disregard for sanitation characteristic of SouthAmerican peoples, they throw their refuse into the shallow water close to their doors, and they appear to have been following this system for quite a length of time without having to pay any penalty for their sins against cleanliness. This may serve as a lesson to more civilised people that there is yet much to be learnt in the science of sanitation.

The cathedral and plaza, government buildings and principal houses, are on the top of the hill, where it is almost flat. Those learned in historical detail point out the spot quite close to the National College where Simon Bolivar suddenly decided upon the colours of the infant republic he had founded. Suggestions were being made by a party of ladies and gentlemen assembled for the purpose of fixing upon a national flag, when a rainbow appeared in the heavens. "What finer colours could we think of for our flag,' exclaimed the Libertador, 'than those of the rainbow?' And this is how the Spanish- 
American republics came to possess those gaudy flags made up of all the colours of the rainbow.

If one strolls away from the plaza towards the south, the cemetery, which is situated outside the town, can be seen. It is said that this cemetery is one of the finest in South America, many of the mausoleums having cost thousands of pesos to build. I did not feel inclined just then to tramp through the heat and dust of the plain beneath to visit the last resting-place of the people of Ciudad-Bolivar, so I walked towards the river, down one of the steep ill-paved streets leading to the business part of the town. All the principal commercial houses face the river. They are owned chiefly by Corsicans and Germans, who have monopolised the trade of this part of Venezuela. They receive their goods and make their shipments through Trinidad, although sailing-vessels and sometimes steamers visit the port direct from the United States. Up to quite recent times the navigation of the Macareo by steamships was a monopoly, out of which the presidents and high officials of Caracas made money; but towards the end of last year General Castro issued a decree annulling the privileges of the company which owned the concession, thereby throwing open the navigation of the Macareo to the shipping interests of the world. Unfortunately the unsettled state of the country stands in the way of any enterprise in that direction. The advan. tages of the route by the Macareo are so obvious to anyone acquainted with the relative positions of Venezuela and Trinidad, that no details need be entered into here. It is sufficient to state that the few lines which have tried to compete with the one from T'rinidad, by using the main mouth or boca grande of the Orinoco, have invariably had to shut down after a while. 
Above Ciudad-Bolivar flat-bottomed steamers of the same type as those running to Trinidad, but smaller in size, do the carrying trade as far as the towns on the Apure and Meta. Up to some three years ago these lines of steamers were in different hands, but the companies have been amalgamated; so that to-day the Orinoco Shipping and Trading Company own the bulk of the steamers on the Orinoco.

Between the months of January and March, or April, there is no steam communication with the towns on the Upper Orinoco. The river and its tributaries are then at their lowest, and their navigation becomes difficult, owing to the ever-shifting sandbanks which encumber their beds. During these months, therefore, the steamers remain idle. By the beginning of April there is generally a sufticiency of water to allow of the resumption of traffic. In August and September the rivers reach their highest point, and it is not unusual during an excessively rainy season for considerable tracts of country to get flooded. When this occurs a good deal of damage is the result. One of the most remarkable overflows in recent times occurred in 1891, when the ground floors of all the stores along the quay at Ciudad-Bolivar were under water to a depth of two or three feet. A stone pillar marks the height attained by the waters during that disastrous flood. The difference between the highest and lowest points of the water during the rainy and dry seasons is usually about eighty feet. MIr. Spence, in his work, "The Land of Bolivar,' has attributed the rising of the Orinoco to the melting of the snows in the Andes (vol. i. p. 78), ${ }^{1}$ but this explanation is absurd, for in tropical countries where

\footnotetext{
1 'The waters at Ciudad-Bolivar rise $80 \mathrm{ft}$. when the melted snow from the Ancles comes down.'
} 
the temperature varies but littlc, the snow on the mountains does not melt more at one time of the year than at another. As a matter of fact, the rise of all these rivers is the result of heavy rains in the interior during the rainy months. Although the trade of Ciudad-Bolivar is considerable, it is nothing to what it might be. The Venezuelan government, with a short-sighted policy which is almost incredible, has persistently debarred Colombia from making use of that natural highway to the Atlantic, the Orinoco: with the result that the Colombian towns on the eastern slopes of the Andes, instead of using the waterways which form part of the Venezuelan system, are forced to do all their trade through their own territory. With an intelligent government, able to grasp the advantages of abolishing the restrictions against the sister republic, and stable enough to encourage the investment of foreign capital, the possibilities of the Orinoco as a commercial highway would be considerable. The cataracts between Atures and Maipures are a serious obstacle to the navigation of the Upper Orinoco. Yet it would be quite possible, by the construction of a short railway along the river, and the establishment of a line of steamers above the cataracts, to obtain regular communication with the country around the Upper Orinoco and its tributaries, a region rich in rubber and other forest-products. Unfortunately, there is no immediate likelihoor of any beneficial change taking place in the affairs of the country. During the frequent revolutions from which Venezuela has suffered in recent years, the overthrow of one government has been generally succeeded by the establishment of another even worse than its predecessor. Is it any wonder, then, that the commerce of a country so miserably administered 
should be on the wane? That there should be any prosperity at all speaks volumes for the natural resources of Venezuela.

The principal exports of Ciudad-Bolivar are hides, rubber, tonca-beans, feathers, and copaiba oil. The hides come from the towns of the llanos, ${ }^{1}$ those vast plains which extend in a northerly direction, from the left bank of the Orinoco to the mountain range on the Atlantic, and stretch towards the west as far as the very Andes themselves. Rubber, tonca-beans, and copaiba are forestproducts from the wooded region on the right bank and around the headwaters of the stream. The feathers, known in the trade as ospreys, are sent from the country on the banks of the Apure and the Arauca. The swamps in the vicinity of these rivers are the abode of numberless flocks of wild-fowl, of which two varieties of egret are abundant. It is from these egrets that the feathers which form so expensive an article of commerce are obtained. The small egret (Ardea candidissima) produces the most valuable plumes; from the larger birds (Ardea garzetta) a coarser feather is obtained which is not so much appreciated, but the wily dealer can sort his plumes so as to introduce a fair proportion of the inferior article without danger of detection. Quite a number of birds have to be slaughtered to produce a pound of feathers, only a few drooping plumes from the backs of the birds being taken. The season for collecting extends through the months of June, July, and August; that is, through the mating and breeding period. The egrets are wary birds and difficult of approach except when they are nesting or rearing their young, and it is at this time that the collector obtains his feathers. The persistence with which the same localities

1 Plains covered with grass are called llanos in Venezuela. 


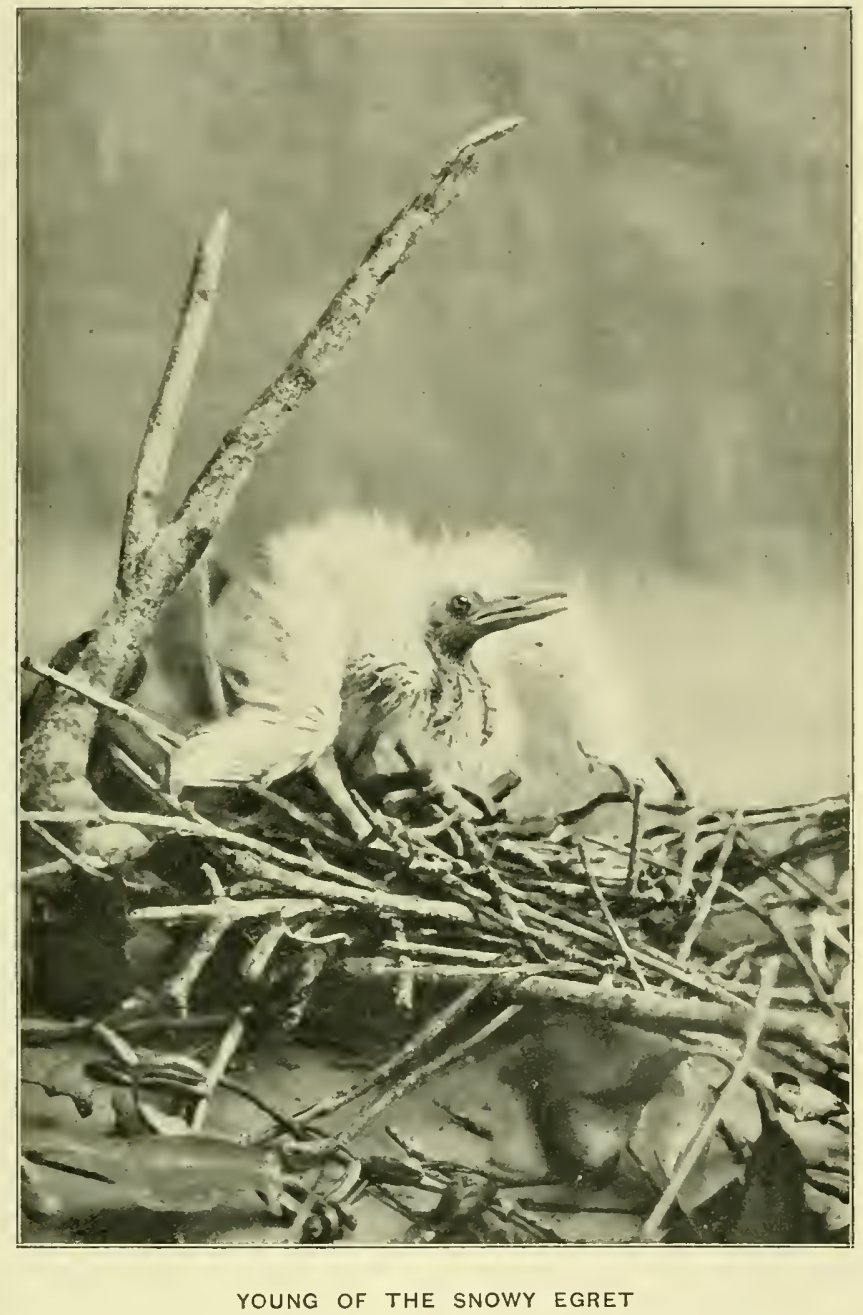



are chosen by the birds for this purpose, year after year, is an instance of that extraordinary predilection on the part of many birds, to repair to the spot where they themselves have been reared, for the purpose of nesting. These spots are called garceros, ${ }^{1}$ and as they are generally upon private lands, the owners make quite an income by hiring out the privilege to kill egrets. As much as 2,000 pesos, equal to 1,600 dollars of United States money, have been paid for this privilege on a single garcero during one season. In spite of the slaughter of thousands of these birds, the garceros continue to be used by the egrets, but in ever diminishing numbers. The beauty of a few feathers on their backs will be the cause of their extinction. The love of adornment common to most animals is the source of their troubles. The graceful plumes which they doubtless admire in each other have appealed to the vanity of the most destructive of all animals. They are doomed, because the women of civilised countries continue to have the same fondness for feathers and ornaments characteristic of savage tribes.

Hides, which are exported in a dry state, go to the American market. Of rubber, two kinds are shipped: true rubber, the product of trees of the Micrandra family; and balata rubber, obtained from the genus Sapoteæ, the principal source of supply being Mimusops balata. The true rubber, or rather indiarubber, is similar to the article exported in such large quantities from Pará in Brazil, and like the Brazilian product it comes from considerable distances in the interior. Whereas indiarubber has been known to science for quite a length of time, ${ }^{2}$ and has

1 The word garcero is also used to designate the heron-hawk (Falco).

2 Torquemada in his De la Monarquia Indiana, published at Madrid in 1615, says, "There is a tree which the Indians call Ulequahuitl; it is 
been put to commercial uses for more than half a century. It is only within the last decade that an extensive trade in balata gum has sprung up, although so far back as 1857 Professor Bleekrod called attention to its value as a substitute for guttapercha. ${ }^{1}$ The tree producing this gum is one of the largest of forest trees. Its timber is exceedingly hard, heavy, and durable, and is of a fine claret colour. It is found all over the West India Islands and in Venezuela, being particularly abundant in the Guianas, where the preparation of balata gum has become within the last four or five years a very important industry. Unfortunately the method employed to obtain the gum is sure to lead to the destruction of this industry which, if conducted on intelligent principles, might constitute a permanent source of wealth to the countries where the balata-tree is found in the forests. It is almost impossible to exercise any control over the gum collectors in the vast expanses of forest where their operations are carried on, so that they are at liberty to work in whatever manner they choose; and they have in consequence adopted the method which gives the least labour and the biggest return. Instead of judiciously tapping the trees, the gum collectors throw them down; and then, by scoring the bark of the trunk and branches, they secure all the sap they can, which they then boil and cast into rough moulds. Sometimes the gum is brought to market in the shape of large blocks. The experienced trader, who has learnt that these blocks may contain heavy stones or other materials not as valuable as gum, is very careful in dealing with this class of merchandise.

held in great estimation and grows in the hot country. It is not a very high tree; the leaves are round and of an ashy colour. This tree yiclds a white milky substance, thick and gummy, and in great abundance.'

1 Joumal Soc. Arts, October 9, 18:37. 
Like most hard-wood trees the balata is of very slow growth. Those giants of the forest recklessly destroyed in a few short hours have taken hundreds of years to attain their full development. In ten or fifteen years there will not be, it is to be feared, a single balata-tree in the districts where gum is being obtained by the destructive system in vogue amongst the collectors. What is most to be regretted in the wholesale destruction of these trees is that the very valuable timber they might supply is allowed to remain and rot on the ground. Of course the reason for this is that in most cases the trees are found in the depths of the forest far from any road, so that the dragging out of logs of this heavy wood would be an undertaking too costly to leave any return on the outlay.

In former times no taxes or export dues were levied in Venezuela on the products of the country, the object of the government having been to encourage and protect native industries and agriculture. Now all this is changed. Some fifteen or twenty years ago one of the presidents introduced the thin edge of the wedge of adding to his revenue and to the incomes of his satellites by putting a small shipping-tax on one of the exports. I think it was coffee. The plan answered so well that other products were added to the list of dutiable exports, while the taxes were increased at every opportunity. Balata pays to-day 25 centimos of a bolivar ${ }^{1}$ per kilogram; feathers, 50 bolivares or nearly 10 dollars; hides, 15 centimos; tonca-beans, 25 centimos; coffee and cocoa, 10 centimos ; cattle per head, 10 bolivares. These are government charges. An additional 25 per cent.

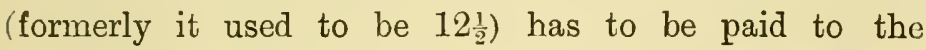

1 A bolivar is equal to a franc in value, and a centimo to a centime. 
municipality, ostensibly for the upkeep of the roads and streets and for other expenses incidental to towns. Little of the revenue, however, is ever spent in improving, or even in keeping in order, the towns and the roads connecting them, even the streets remaining unswept for weeks and sometimes months. Too many men make a living out of politics in most of the Spanish-American republics to allow of a decent portion of the revenue of the country being spent in improvements. It is true that in many cases the taxes I have just enumerated are not paid in their entirety. It is not very difficult to make arrangements with the officials whereby only a portion of the tax is paid, the deal being a private one in which the authorities at Caracas are ignored. In a country like Venezuela, where the import duties are out of all proportion to the value of the articles on which they are imposed, the incentive to smuggle is exceedingly powerful. The tariff, or arancel as it is called, enumerates nine classes of merchandise of which Class 1 only is free: Classes $2,3,4,5,6,7,8$, and 9 pay respectively 10,25 , 75 centimos, 1 bolivar and 25 centimos, 2 bolivares and 50 centimos, 5 bolivares, 10 bolivares, and 20 bolivares. ${ }^{1}$ All duties are collected on the gross weight including package, and the figures mentioned above are for each kilogram. The importation of coffee, cocoa, cocoanut oil, starch, and salted beef is prohibited; so is the importation of salt, the procuring and disposal of which from various deposits on the northern seaboard is a government monopoly constituting a source of considerable revenue, now collected by the Bank of Venezuela in repayment of debts contracted by the rulers of the country.

T'here are several extensive salt-pans in Venezuela,

1 These figures are from the Arancel issued at the end of $\mathbf{1 9 0 0 .}$ 
notably at Coro, Coche, and at Araya to the north of the town of Cumaná. The last mentioned is, I believe, by far the most important of the lot; and, as I happener on one occasion to be a passenger from Cumaná to $\mathrm{La}$ Guaira on board a schooner which touched at Araya and took a cargo of salt, I shall describe the system followed by the government in controlling the sale of this very necessary article. To Ciudad-Bolivar and the other towns on the banks of the Orinoco situated in the llanos where numbers of cattle are reared and much beef preserved, salt is a commodity of such importance that a detailed account of how it is procured will not be out of place here.

When a trader decides on a deal in salt, his first care is to obtain the polizas, or permits, with which he can proceed to the salt-pan he has fixed upon for taking his cargo. At La Guaira or Puerto Cabello he can secure polizas for any of the pans, but if he happen to be at any other port, such as Cumaná or Juan Griego, he can only obtain permits for the salina ${ }^{1}$ lying within the jurisdiction of the town where he is. The money for the salt must be paid in advance, and then the trader obtains his polizas specifying the quantity of salt he has bought, and is entitled to take from the salina on which the order is issued. For several years the average price at which these permits have been granted is 10 pesos $^{2}$ the fanega of 130 kilograms; that is equivalent to 8 dollars for 300 pounds, or very nearly 3 cents per pound. When Humboldt visited the salt-works of Araya 103 years ago the price of salt was 12 reals-this is 1 dollar and 20 cents the fanega- and the deposits were then, as they

Salt-pan.

2 A peso is equal to 80 cents U.S. money or $3 s .4 d$. sterling. 
are now, under government control. By comparing the value of the article in Humboldt's time and what is charged for it to-day, we see what an advance there has been in the price of this necessary.

Araya is a barren stretch of land forming a small peninsula at the western extremity of that long narrow strip separating the gulfs of Cariaco and Paria from the Caribbean Sea. A few cacti, with here and there a patch of thorny scrub, is all the vegetation the dry calcareous soil can support. The whole place looks so desolate, so unfit for animal life, that one is surprised to learn that wild rabbits exist in such numbers that they are sold at a medio, or $2 \frac{1}{2} d$. a piece. Large flocks of goats may be seen wandering over the hillocks where the scrub is thickest. It is in such inhospitable regions that we come to realise to what an extent life is capable of adapting itself to the most adverse conditions. To be more accurate when speaking of life, I ought to have said not only of adapting itself to the most adverse conditions, but of thriving in spite of them. Although we do not meet with many different species in a district where fresh water is wanting and vegetation scarce, yet we cannot fail to notice that whatever does exist in such localities is vigorous of its kind and difficult to destroy. Midway between the seashore and the lagoon where the salt is obtained, is the collection of houses forming the village of Araya; and here, in one of the best houses, lives the Administrador de la Salina. T'o be Administrator of the salt-pan at Araya is the ambition of many of those place-hunters whose business is the setting up or overthrowing of presidents, for the post is considered one of the best political rewards in the Republic. On the occasion of our visit a tall dignified old gentleman with a 
long grey beard was Administrador de la Salina, and to him our captain handed over his papers, arranging at the same time to take in his cargo on the following inorning. The village of Araya is not a cheerful sort of place according to European ideas, but the people appear to enjoy themselves in their way, as the frequent visits of schooners and smaller craft are occasions for parrandas and dances, amusements dear to the heart of the Venezuelan. The captain, who was also the owner of our schooner, insisted that I should accompany him in the evening, when he would call on his friends. On such occasions, he told me, he was always accompanied by his crew, every one of whom could play some stringed instrument. Don Laureano, for that was the name of our skipper, was very particular on this point, and he used to say that even the cook had to be a musician, otherwise the schooner was no place for him. After dark we wandered forth, but not like 'the sons of Belial swollen with insolence and wine,' and going from door to door our musical crew played joropos, ${ }^{1}$ waltzes, and polkas for the benefit of the people of the house we meant to honour. We were generally invited in, and the chairs and tables having been cleared away we danced with the ladies, so that good music, as they said, might not be wasted. This strolling from door to door with music, somewhat after the fashion of Christmas waits in England, is called parandear. Una parranda is the name applied to this form of amusement, and as it is not unusual for those who indulge in these parrandas to get festive on occasions, a man who has a weakness for sprees is called a parrandero. These terms will

1 Pronounced horopos, the favourite dance of the peasant and labouring class. 
not, I believe, be found in any Spanish dictionary; they are essentially Venezuelan.

If I have described the light side of a visit to Araya before tackling the serious business of the handling of a cargo of salt, I have but followed the system in vogue in the country I am writing about, the motto of whose inhabitants is, pleasure before duty.

The salt is gathered from the edges of a lagoon of intensely saline nature, the bed of which is composed of a thick deposit of crystals of chloride of sodium ${ }^{1}$ mixed with some earth and sand; and, according to Humboldt, surcharged with muriate ${ }^{2}$ and sulphate of magnesia. ${ }^{3}$ This salt deposit, still in course of formation, gives one a very good idea of how those beds of rock-salt, so extensively worked in Austria at depths of many hundreds of feet, were formed in the past. We can imagine that mine in Galicia, in whose bowels Polish criminals have toiled their lives away, being at one time a broad sheet of water glistening in bright sunlight in a region where it never rained. And the stretch of open country on which we stood drinking in the fresh sea-breeze and enjoying the glories of the sunshine, will it not also be buried with its wealth of salt in the depths of the earth, to be, perhaps, the prison-house of the convicts of a future generation?

From the salina the salt, put up in bags, is carried by donkeys to the seashore, where it is taken on board by the crew. The vessel, having completed her cargo, sails to one of the coast towns or beats her way up against the current of the Orinoco to Ciudad-Bolivar, where the price of salt is generally 15 pesos the fanega. Considering that the same sort of salt can be obtained at Trinidad at something like $3 s$. the barrel of 300 pounds, we

$$
1 \mathrm{NaCl} \text { = } \quad \mathrm{MgCl}_{2} \text {. } \quad \mathrm{MgSO}_{4} .7 \mathrm{H}_{2} \mathrm{O} \text {. }
$$




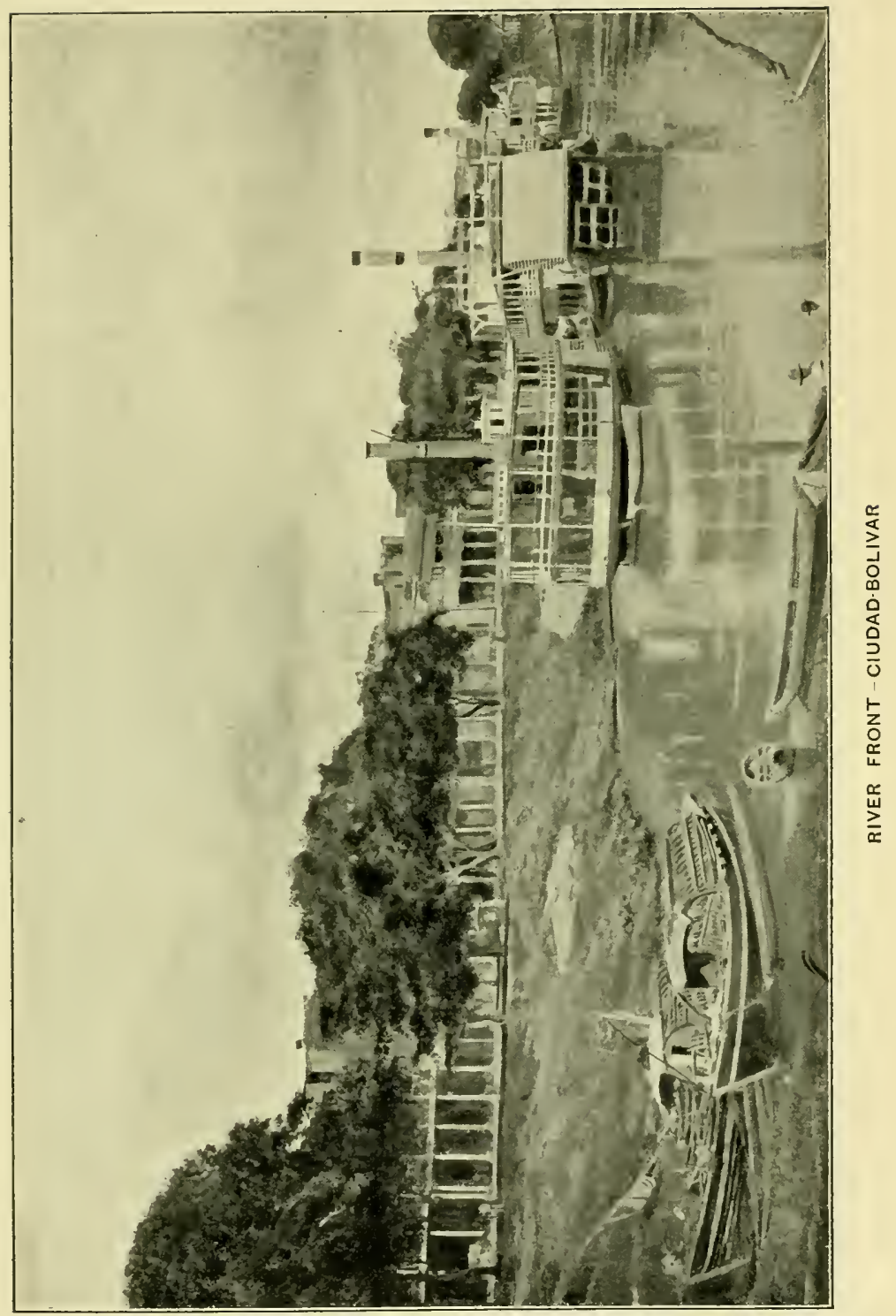



can understand the temptation the illicit introduction of this article holds out to the man with smuggling instincts. The capital required for such a venture is a matter of 2,000 dollars at the outside, as a small schooner or sloop with a full load of, say, 1,200 bags of salt representing 600 fanegas, would mean an investment of about 400 pounds sterling only. Should the venture be a successful one, and I should say these ventures generally are, because the men who undertake them are known to be desperate and determined characters, with whom the officials would rather not have any misunderstanding, the return on the outlay is so considerable that it pays the cost of the vessel and leaves a handsome profit besides. So that, even if the regular salt smuggler meets with bad luck now and again, still in the long run his profits are so large that he can well afford to lose a rotten schooner from time to time. The best results are obtained, I understand, from a mixed cargo of salt, gunpowder, white sugar, flour, and brandy. My informant, I have every reason to believe, knew what he was talking about when he furnished me with the above list. The principal article of food at Ciudad-Bolivar is beef, although at certain seasons a fair supply of fish can be procured from the Orinoco, and then the regular meat diet is varied with some fish. The people of Venezuela might well be divided into two sections : those who eat beef and those who eat fish. The inhabitants of the plains are naturally beef-eaters, but on the northern coast, separated from the llanos by ranges of high mountains across which it is expensive to drive cattle, the chief article of food, especially of the poorer class, is fish, either fresh or salted. Fish salted and dried in the sun is sent in quantity from Cumaná to the villages in the moun- 
tains, where, boiled with vegetables, it forms the sancocho of the mountaineers. The people are not delicate in their tastes, sharks and other coarse fish being largely eaten. In fact, it would appear that a strong taste of whale oil is appreciated, for the fish most extensively consumed in Venezuela is to my mind one of the coarsest flavoured of all fishes. It is called jurel, ${ }^{1}$ and as it is very abundant, being met with in large shoals off Cumana and in the Gulf of Cariaco, its capture and curing give employment to a number of people. In addition to fish, much pork is consumed all over this region, where pigs are reared in a semiwild state and have to forage for themselves. Although cases of leprosy occur everywhere in Venezuela, Cumaná and Maracaibo are the places where the proportion of lepers to the rest of the inhabitants is greatest. The people unanimously attribute the prevalence of the disease to the diet of fish and pork on which they subsist. I have heard more than one Venezuelan say that pork and fishes without scales give leprosy. Has this saying sprung up in the country or is its origin connected with the Old Testament? ${ }^{2}$

With reference to fish as an article of food I am reminded of a curious method of fishing in vogue at CiudadBolivar which I do not remember to have seen anywhere

1 Scomber carangus.

2 Leviticus xi.:

7. And the swine though he divide the hoof, and be cloven-footed, yet he cheweth not the cud, he is unclean to jou.

8. Of their flesh shall ye not ent, and their carcase shall ye not touch, they are unclean to you.

10. And all that have not fins and scales in the seas, and in the rivers, of all that move in the waters, and of any living thing which is in the waters, they shall be an abomination unto you.

12. Whatsoever hath no fins nor sealos in the waters, that shall be un abomination unto you. 
else. I had wandered to the suburbs of the town, along the river's bank, where several fishermen were throwing their lines. I noticed that they used no bait, their object being to hook the fish by the body. To a long line a cylindrical weight is tied. Above the weight, for a length of about eight feet, and at distances of six inches, strong fish-hooks are attached. The line is thrown out in spots where the current runs swiftly, and then hauled rapidly in by a series of jerks. This system of fishing is called robador, literally 'to rob,' and it is surprising to see what quantities of fish can be caught by an expert fisherman in this manner, without a particle of bait.

Ciudad-Bolivar supplies most of the cattle used in Trinidad. The animals in many cases come from considerable distances. Suffering from fatigue and hunger, they are packed so close on board the steamer that they dare not lie down for fear of being trampled upon. The enraged oxen spend the two days on board trying to gore each other to death, and it is not to be wondered at under these circumstances that the beef used in Trinidad is usually tough and unpalatable.

The soil of the country around Ciudad-Bolivar is poor and is suitable for little else than pasture-land. It consists either of hard red clay mixed with pebbles, or sand supporting a sparse and stunted vegetation; but in the hollows, especially where there are pools or streams of fresh water, there are trees of vigorous growth and the grass is more luxuriant in character. These oases are called morichales, on account of the predominance of the moriche palm in the vegetation with which they are clothed. In the vicinity of the town the morichales are used by the well-to-do inhabitants as country seats to which they can escape from the heat and dust of the city. 


\section{CHAPTER V}

Cock-fighting and its history-The training of cocks in Venezuela-The cockpit-Bull-fighting-Carréras de Cintas-Golfo-Paro Pinto-Monte de Dados-Gambling banks.

THE day after our arrival at Ciudad-Bolivar was a Sunday. In Spanish-American countries Sundays and the numerous feast-days of the calendar are set aside for amusement. In studying a people I cannot help thinking that there is as much to be learnt by observing them in their pastimes as by associating with them in business, and that is why if I traded with a Venezuelan on a Saturday I did not hesitate to accompany him to the bull-ring, the cockpit, or a gambling-den on the Sunday. In every form of sport, as in everything else connected with their lives, Spanish-Americans give evidence of their excessive conservatism. If we compare English sport of to-day with that of 300 years ago, we cannot fail to be struck by the different view taken now of certain forms of amusement and that which prevailed in the sixteenth and seventeenth centuries. Who would dream in these days of holding a cock-fight in public anywhere in England, except he had made his mind up to stand the risk of being arrested and brought before a magistrate for breaking the law? Yet it is not so long ago that kings, lords, and even bishops bred and fought cocks in good virtuous old England. In an old book dealing with orders on the Exchequer in the reign of James I., we find frequently repeated the following order: '16l. 13s. $4 d$. 
to William Gatacre, for breeding, feeding, and dieting of cocks of the game for His Highness' recreation.' Pepys relates in his quaint manner how he went to Shoe-lane to see a 'cocke-fighting' at a new pit there, a spot he had never been to in his life. 'But, Lord!' he says, 'to see the strange variety of people, from Parliament man to the poorest 'prentices, bakers, brewers, butchers, draymen, and what not.' Anyone who cares to look up the history of cock-fighting will find, amongst other names, those of Lord Derby, Sefton, Anson, and Lowther, as having been enthusiastic patrons of the sport. One noted dean of York frequently attended the cockpit, and bred such fine cocks as to hold his own against all comers. At York the cockpit was near the Cathedral, and at Canterbury the cockpit was an apartment of the gateway forming part of St. Augustine's monastery. It would appear to be a curious coincidence that in several places in Venezuela the cockpits are close to the churches, but such coincidences can easily be accounted for, considering the convenience of an arrangement which provides for one being able to attend to his devotions without having to walk too far afterwards to win money on a favourite bird.

Cock-fighting is the national sport of SpanishAmericans, and on Sundays, the great day for important events, the sport lasts the greater part of the day. The origin of cock-fighting is wrapped in obscurity. It is probably the oldest of all the sports in which man obtains pleasure out of the sufferings of the lower forms of animal life. Three thousand years ago the Lydians fought cocks on the banks of the golden Pactolus, and it is pretty certain that long before this the pastime was a popular one with the peoples of India and Persia. We are told that Themistocles, the Athenian general, encouraged his 
soldiers' valour by pointing out to them two cocks fighting, saying: 'These birds fight not for their gods, nor for their children, nor for glory, nor for freedom, but for the sake of victory, that one may not yield to the other,' the example of the cocks having such an effect on the flagging spirits of the soldiers that he led them once more to victory. If the example of two cocks fighting led the soldiers of Themistocles to victory, might it not be pardonable to infer that the prevalence of cockfighting in Spanish-American republics may be in some measure connected with the pugnacious and revolutionary spirit of the people?

As I do not remember to have seen anywhere a full description of the training and fighting of cocks in Venezuela and Colombia, although such a description would certainly prove of interest to some, I propose to make an attempt at explaining all the niceties of this exciting sport as I studied it at Ciudad-Bolivar and in various towns of the two republics.

Between the months of June and November there are no regular cock-fights. The birds are then in the moulting stage, and their feathers being soft and full of blood incapacitate them for a prolonged engagement. During that time, therefore, they are allowed to roam about with a few hens, care being taken that each male bird has a run for himself and his harem of wives. A visit on the part of any other male bird would be sure to have disastrous results for the owner or owners of the birds. By November or December most of the birds have acquired new suits of clothes and are ready to undergo training. In countries like Venezuela and Colombia, where cock-fighting is carried on extensively, the training of the birds is conducted with the greatest 
care, as much trouble being taken with the feathered gladiators as is bestowed in England on a possible Derby winner. Quite a large number of men in the countries I have mentioned do absolutely nothing else for a living but train cocks. They are called cuidadores de gallos. ${ }^{1}$ The first operation a bird undergoes as soon as he enters the gymnasium, which, by the way, goes by the name of una cuerda de gallos, ${ }^{2}$ is performed by the barber of the establishment-a sort of shave and brush up. Some gymnasiums boast of regular artists, whose birds always look spick and span. These men take as much trouble with the feathers of their charges as a Bond-street tailor does with the clothes of a dandy. After the bird has passed through the hands of the barber and tailor he is so altered in appearance that his own mother would not know him. His head, legs, and posterior are bare, and these parts assume after a short time a bright reddish colour. When he is brought in he is sure to be infested with parasites such as lice and ticks, so he is given a bath of strong rum, with the result that he usually gets very drunk on the first day of his arrival at his training quarters. To the honour of these feathered pugilists it must be conceded that, unlike human beings, they appear to take no pleasure in getting drunk, thus supplying another powerful argument in favour of the inferiority and utter soullessness of the lower animals. The bird having recovered from his intoxication, and having been dosed with some medicine so as to clear his head, enters on the serious work of training. Every cock is fought in some particular weight, known as his weight. If you are being shown around a training establishment, you will be told, that Zambo is a 3.10 ; that Canaguey is 3.4 ; and

1 Literally, caretakers of cocks.

2 Training school for cocks. 
the Gallo Giro in the corner is a 3.8. For the enlightenment of the uninitiated let me explain that the terms employed are those used to designate the birds by their colour. Thus Zambo means a black-red, Canaguey is equivalent to the English Pile, and Giro to the yellow Duckwing.' In Venezuela the fighting weight of the gamecock rarely exceeds four pounds, the weights ranging as a rule from that down to three pounds, so that when a trainer says 3.10 in particularising some bird he means that his fighting weight is three pounds and ten ounces, but he considers it superfluous to mention the pounds and the ounces.

On the third or fourth day after the birds have been taken in, the trainer arranges sparring matches between those of similar size. The spurs of the sparrers having been carefully covered with wadding or cork, so that no severe wound may be inflicted during the trial, they are allowed to hammer away at each other for some time in much the same manner as prizefighters do with the gloves when they are preparing for a serious engagement with the naked fist. This operation, which is called topar, serves to give some idea of the powers of each bird. After this the training is carried on regularly for a period ranging from four to six weeks, when the bird is ready for the pit. Although there may be slight differences in unimportant details in different districts, the system of preparing cocks for the pit is in the main much the same all over Venezuela and Colombia. At daybreak the birds are bathed

1 It would take a whole vocabulary to express the names of all the colours by which gamecocks are known in Venezuela. The hencocks or hennies alone, which are of every shade of colour and varicty of marking, would fill a long list. In Spanish-America, so far as I have been able to learn, cocks are not bred true to colour and no weight appears to be attached to this point, the saying being that no good cock is ever of a bad colour. 
in cold water, after which they are tied to pegs in the sun, where they remain until about ten o'clock, when they are put in their coops. Each bird is then weighed' and exercised singly for about a quarter of an hour or twenty minutes, the exercising being done by the trainer holding by the legs another bird which he moves rapidly above and in front of the one on the ground. This is probably the most barbarous part of cock-fighting, for the poor bird which has daily to be pecked at and battered by a dozen others presents at the end of a few days a lamentable appearance. This method of exercising is called carear, and the bird employed for the purpose is known as a careador. It is necessary that the careador be game and plucky, otherwise he will refuse to beak (picar) and thus. provoke the bird he is exercising to continue to strike at him when the latter gets tired. After the carear the bird. is rubbed down and returned to his coop. He is fed once a day, chiefly on maize, with a little raw beef and hardboiled egg twice or three times a week. The greatest attention is paid to the amount of water allowed him, this being reduced until he gets only two or three mouthfuls daily. At last the day arrives on which he is taken to the cockpit, whither we will accompany him to be witnesses of his indomitable spirit, and of his contempt of suffering and death. When we reflect upon the pride most men feel in being considered brave, and we note the rewards showered upon those who have exposed themselves to pain and death, even if it be in an unjust cause, we cannot help being struck by the inconsistency of a race of beings who, while looking upon themselves as the lords of creation,

1 A regular weighing-book is kept, in which the weights are entered from day to day, so that the trainer may regulate the quantity of water to be given to each bird. 
hold in the highest esteem a qualification which they do not possess in nearly so great a degree as many of the lower animals.

There is no village, however poor, throughout the length and breadth of Venezuela, that does not boast of a cockpit of some sort. In these cockpits every man is equal, and it is no unusual thing to see a barefooted peon pitting his favourite bird against that of the most influential man in the state. At times mains or series of fights are arranged between different towns or districts, but this is not the rule, the cock-fights one witnesses usually on Sundays being conducted in the following manner. A man steps into the pit holding a cotton bag in which is a cock. He may be, as I have already said, a barefooted peon or a general in a frock-coat and patent-leather boots. He holds up his bag and says, "I have got a 3.10 for fifty pesos.' ' Someone is almost sure to answer from among those present, 'I will match you,' and a few moments after he also steps into the ring, holding a bag similar to that of the challenger. In every cockpit an ordinary pair of scales, from which the pans have been removed leaving only the bar, hangs from the roof, and on this arrangement the cocks are weighed, or rather matched, the bags being attached to each end of the bar. An ounce is allowed as a rule. ${ }^{2}$ The birds, having been declared a match, are removed from their bags, when the spectators are able to see them and make their bets. While the spurs of the cocks are being sharpened, for artificial spurs or gaffles are not in use in Venezuela, betting

1 The amount quoted is the minimum amount the owner intends to pit his bird for. Winners of several fights are fought for large sums.

"When the birds are so evenly matched that the needle of the bar remains perfectly perpendicular, the weights are said to be oro, literally gold. 
proceeds furiously. Amidst the din of voices may be heard 'I am for the red cock, twenty pesos.' 'Thirty on the black.' 'Fifty on the red.' 'Done.'

The setters stand before the judge, arrange the terms of combat, and fix upon the length of time beyond which it is to cease. ${ }^{1}$ The spurs of the birds are thrust into limes and withdrawn, there being a widespread belief that the acid juice of limes renders innocuous any poison with which an unscrupulous setter may have smeared the steellike weapons of his bird. Each setter fills his mouth with water, which he blows on his charge in a cloud of fine spray. This is an art in itself, acquired only by long practice; if anyone who reads this be incredulous on the point, let him try.

And now the birds stand face to face in the arena, with a crowd of excited men and boys watching their every movement. Slowly they draw together, each one cautiously noting every action of his adversary. Perhaps there is a wild rush in which one bird is killed outright as if struck by lightning, but this happens rarely, even the best fighters taking several minutes to dispose of an opponent. Covered with blood, with the skin hanging from their heads and necks, sometimes stone blind, staggering and falling, but still trying to inflict some deadly injury, unyielding to the last, these noble birds lay down their lives while a mass of howling humanity is making wagers on the result.

Every town of any importance has its bull-ring, where toreadors and matadors from Spain display their skill or lack of it. In Venezuela bull-fighting is a tame affair when compared with the sport in Spain, where bulls of a

1 Thirty minutes is the time usually fixed upon. If at the end of the thirty minutes the fight remains undecided, it is declared a drąw. 
ferocious breed are reared specially for the ring. The emasculated animals seen at the corridas de toros $^{1}$ at Ciudad-Bolivar are not the fierce brutes who kill horses, toreadors, and matadors in the rings of Seville and Madrid. One great improvement in the sport as conducted in Venezuela, although but few Spaniards, I am sure, would consider it an improvement, is the elimination of the picadors with their horses. Since Byron composed his splendid stanzas on the bull-ring of Seville so much has been written about bull-fighting in Spain, that a long description of the poor imitation of a Spanish corrida de toros to be seen at Ciudad-Bolivar could not be otherwise than tame; therefore I have thought it best not to attempt one. In some of the smaller towns where no regular construction for bull-fighting exists, the people find a way of gratifying their ingrained love of this form of sport by letting an ox loose in the principal street, the inhabitants having closed their doors and the ends of the street being barricaded. The llaneros or cowboys of the country, who are experts in the use of the lasso and call successfully dodge the wild rush of an infuriated ox, amuse themselves and the spectators who are safe behind the bars of their windows by torturing the poor animal until he is thoroughly exhausted. Another form of amusement indulged in on Sunday afternoons in some of the streets of the towns, is tilting the ring. ${ }^{2}$ To an arrangement stretched across the street, rings are attached by long ribbons of various colours. The competitors, mounted on the swiftest horses they possess or can borrow, and armed with long slender poles, assemble at one end of the street. They ride, either singly or by twos and threes, at a furious pace along the street and, when 


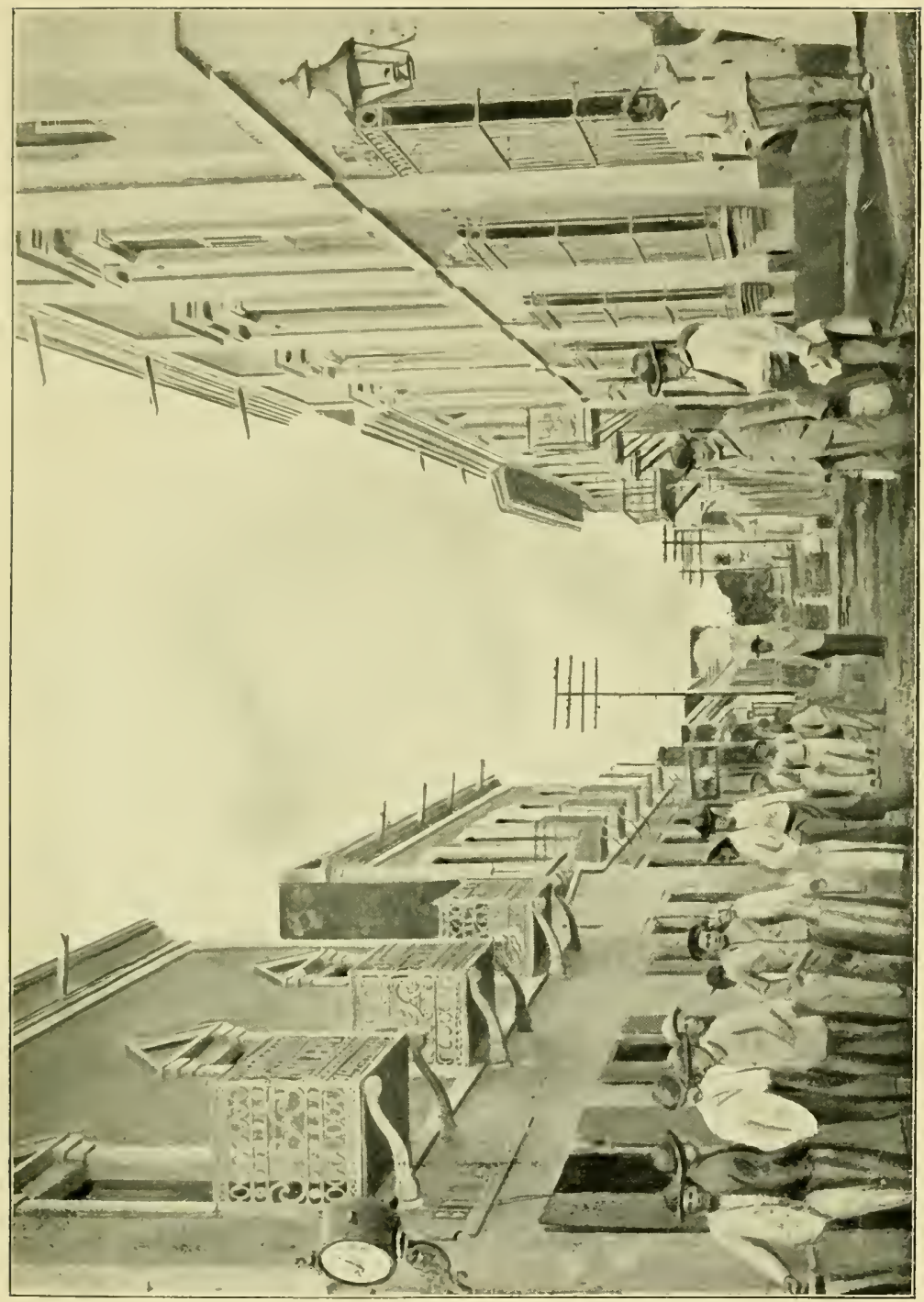

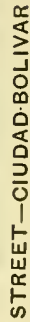



passing under the arrangement with the rings, each horseman tries to carry away one of them on his pole. The one who secures most rings is declared the winner. Sometimes in addition to the rings the horsemen tilt at a crown which is kept moving rapidly up and down by means of a string, and is in consequence a difficult object to capture. I believe that carréras de cintas owe much of their popularity to the opportunities they afford for display. The Venezuelan is fond of show. He is in his glory when, mounted on a fiery steed richly caparisoned, he rides along the principal streets of the town to be admired by the dark-eyed beauties who sit behind their iron-barred windows to look at the passers-by. No quiet horse, however perfect he might be, would suit a caballero's ${ }^{1}$ fancy then. It must be a restless animal; one that rears and curvets, that can turr suddenly on its hind legs with a touch of the rein, or bound forward in leaps on being pricked by the spur. In carréras de cintas the horseman has every opportunity of showing off his horse and himself, and, as I have said before, this accounts in a great measure for the popularity of the sport.

Venezuelans are passionately addicted to gambling. At the clubs various games of cards and dice are played, sometimes for very heavy stakes. In cards, baccarat, golfo, and within recent years poker, are the games most in vogue. Monte de dados and paro pinto are played with dice, and I should say that the latter is essentially the national gambling game, all sorts and conditions of men being addicted to it. Baccarat and poker are so well known in all the most highly civilised countries that they may be dismissed without comment. Besides, they are not of Spanish origin. Golfo, on the contrary,

${ }^{1}$ Caballero $=$ knight, gentleman . 
I had never heard of before I travelled in Venezuela; so a short description of the game may not be out of place here. In Venezuela golfo is played with a pack of Spanish cards out of which the ones, twos and threes, eights, nines, and tens, have been removed, the knaves, queens, and kings counting as the last three.

Five players are the limit, and even then the dealer can only come in if he chooses when one of the players drops out. There is a good deal in common in poker and golfo, the element of bluff, as it is called, being a powerful factor in both games.

The cards are taken from the bottom of the pack and one deal of two cards to each player is made, beginning with the one on the right of the dealer. Up to this part of the game no money has been staked. Each of the players may come in or drop out as he chooses, the first to declare saying 'I pass' or 'I play,' and in the latter case staking the sum for which he opens the game. It is the privilege of any of the other players to raise the sum originally staked, just as in poker. As in poker also, the person next the dealer, but on the right, has the last say, although he does not have to put up an ante. There are three deals in all, the players taking each time as many cards as they may have discarded. The whole object of the game is to make the highest point in one suit, and the highest point possible is thirty-four. Thus the seven, knave, queen, and king of clubs, let us say, would represent thirty-four. If five cards of the same suit be held, the hand is called golfo; but the lowest does not count, as the hand is reckoned on four cards only. At first sight the game appears exceedingly simple, but on reflection it will be seen that a good golfo player requires to pay a great deal of attention to the drawings of the other players, while he 
leeps in mind the cards he has discarded during the three deals, as he may by doing so make a fairly correct guess as to the value of his adversary's hand. When the deals are completed the players bet on their hands and, as in poker, bluffing may be attempted with or without success. These are the outlines of the game, as I have omitted many points uninteresting to any but regular card-players. To enter into all the details and intricacies of golfo would be a question of whole chapters of writing, which could not be otherwise but tiring to the average reader.

As I have said before, paro pinto is undoubtedly the national gambling game. On pay-days the bulk of the peons, as soon as they receive their wages, sit around a blanket thrown on the ground, where they spend hours trying to add the hard-earned reales ${ }^{1}$ of their fellowlabourers to their own slender pay. As a rule the players do not disperse until all the cash has found its way into the pockets of one or two lucky individuals, the rest remaining, to use their own term, limpio. ${ }^{2}$ Paro pinto may be played by any number of persons. The materials are two dice, with a dice-box. If there be no box the dice are thrown with the hand, but this frequently leads to misunderstandings which sometimes end disastrously, as there are certain individuals who are incomprehensibly lucky when they throw with the hand. In such cases the other players will usually object to a persistence of luck in one and the same quarter, and as they get unreasonable in proportion as they lose, the game may wind up with a wake and a funcral. If anyone care to obtain a good idea of paro pinto, let him take two dice and hold them together so that the sixes are uppermost; the opposite sides are ones. The former are winning

1 A reale is equal to five pence or ten cents.

2 Cleaned out. 
points, the latter are losing ones, and they are named respectively suertes and azares, the literal meaning of suerte being luck, and that of azar absence of luck; but these are merely terms, for the unlucky numbers win when the lucky ones lose. The other winning points or suertes are two fives, two threes, and five and six; the losing ones or azares are two fours, two twos, and one and two. Other throws do not count. ${ }^{1}$ Any one of the players begins the game by staking either a single sum or two amounts, one in front of the other. If but a single sum be staked, the player when he throws the dice says 'paro,' and he wins or loses the whole amount by throwing suertes or azares. Should numbers that do not count be cast, then the right to throw passes, and the player throwing does so on the same conditions as he who threw first. When two amounts are staked, one in front of the other, the player says 'paro pinto.' 2 He wins both amounts with the double suertes, the two sixes, the two fives, and the two threes; he loses them with the double azares, the two ones, two twos, and two fours. He wins the sum placed in front only with five and six, and loses it with one and two.

Monte de dados is in reality a modified form of paro pinto, where one man holds the bank and throws the dice, while the players bet either on the right or on the left, the terms suertes $y$ azares being used to indicate the right and left respectively. Every time the banker throws two threes or two fours he deducts twenty-five per cent. from the amount staked on the winning side, so that in the long run the bank is sure to win, as is always the

1 Such numbers as one and three, one and four, two and three, two and four, \&c., do not count.

2 There are modifications of this-where three sums are staked, for instance-but a detailed account of all such combinations would be tedious. 
case where banks for gambling having the odds in their favour are held, however small those odds may be. Most of those who have tried their luck at the tables at Monte Carlo for any length of time must have learnt by experience that the bank always wins in the end.

Before bringing this chapter to a close, I would like to warn those who, imbued with the gambling spirit, may have mastered the principles of the games I have described, and who may in the course of a visit to some SpanishAmerican republic be proud of their knowledge and eager to display it. My advice to such persons is, "Do not gamble with strangers.' You may be a very clever fellow, you may be a good engineer, you may teach SpanishAmericans how to lay a railway or erect a brewery, but you are not going to teach them anything in cards or dice. What the average man of Central and South America does not know in these matters is not worth knowing. 


\section{CHAPTER VI}

Departure from Ciudad-Bolivar, December 6, 1900-The chubásco-The Gates of Hell-Alligator hunting-Trade in alligator skins-On board the 'Caura'-Fish-spearing by torchlight-Mapire.

THE few days spent at Ciudad-Bolivar were employed in purchasing provisions and such other articles as were necessary for the trip, and although one would expect to be able to obtain almost anything in so important a town, I met with the greatest difficulties in my attempts to fit out my expedition properly. Salt was exceedingly scarce, so that I was unable to procure more than three bags of 150 pounds each, and for these three bags I had to pay something like forty pesos, or nearly seven pounds sterling. There was a dearth of peas and rice, but I expected to get all I wanted of these articles on the Caura itself. The dried beef offered me by those engaged in the salting and preparing of meat was old and unfit for food. It is indicative of the backwardness of Venezuela, when compared with another Spanish-American republic, Argentina, that while in the latter country a very good dried beef is prepared which is exported in large quantities, in the former a semi-putrid abomination called carne salada is the only form of preserved beef obtainable. The scarcity of salt and its high price are no doubt responsible to a certain extent for the imperfections of the preparation known as carne salada, but there is another important point to which no attention is paid, and that is the pressing of the beef so as to get rid of the 
juices causing putrefaction. In the Argentine, where tasajo ${ }^{1}$ is prepared in an intelligent manner, it remains wholesome and palatable for several months, whereas the Venezuelan article at the end of a few weeks is offensive in smell and disgusting in appearance. Yet it is impossible to obtain any other kind of prepared beef in Venezuela, as the importation of salted meats is prohibited so that the native industry may be protected and flourish.

The 'Caura,' the steamer which was to take our party up as far as Temblador, had to undergo some repairs before she would be in a condition to undertake the trip, so that our departure was definitely fixed for December 6 . I had purchased one large bongo or dug-out at Trinidad. I required four others, but succeeded in getting only two at Ciudad-Bolivar, as a large number of these boats had been taken from their owners by the contending parties during Castro's revolution, and had either been carried away or destroyed. The two smaller bongos were placed crosswise on the lower deck of the 'Caura,' with their ends projecting over the water; the larger ones were lashed to her sides, this being the most convenient way of towing them. On the 5th (December) our effects were sent on board. After I had seen that everything was in order I returned to the hotel. On this last night of our stay at Ciudad-Bolivar we slept on beds with sheets and pillows, luxuries we would not be able to obtain on the journey which lay before us.

At dawn we hurried down to the spot where the 'Caura' was moored. For a wonder we found that steam was up and the captain ready to start, so that no time was lost in getting under way. We were soon out of "The

$$
\text { ' Salted beef, preserved and dried. }
$$


Narrows,' forcing our way over the broad waste of those waters whose sources lie so far apart. As I sat gazing lazily over the steamer's side at the yellow current sweeping past us, I wandered into dreamland. Whence came that mighty flood which lay ahead of us? The snows of the Andes, the heavy rains of the forests, the thunderstorms on the craggy heights of Parime and Maravaca, had contributed to its volume. Through the grassy treeless plains stretching from the Andes, through the wooded country on the Guaviare, through the gloomy forests of Amazonas, rushing and tumbling from the highlands of Guiana, the waters had met at last and mingled in the current running swiftly past us. They had traversed in their course many a wild and unexplored tract of country, they had flowed past the houses of the little known Guaharibos, through the land of the Maquiritares, by the huts of the Piaroas and Guahibos; they would soon be lost in the blue waves of the Atlantic, whence they had come borne on the wings of the easterly breeze to feed the snows of the white-capped heights of Merida and the torrents that pour on the forests of Guiana.

We soon made ourselves comfortable on board of the little ' Caura.' On the after-part of the upper deck, which had a wooden covering supported by stanchions open on the sides, we slung our hammocks. In this place we spent the greater part of the day and had our meals. The engine, boiler, and stacks of firewood, with the two small bongos, occupied the whole of the lower deck. The crew slept huddled together in the bongos, or on top of the firewood.

During the dry season, when the easterly winds blow with regularity, a good deal of the carrying trade of the 
Orinoco is performed by sloops and schooners, the breeze being powerful enough to drive the vessels up against the current, which is not as strong as in the rainy months. The Orinoco is subject to sudden squalls of a violent nature called chubciscos. The sky assumes a coppery-red colour, followed by strong gusts of wind and fitful showers; the placid waters of the stream are lashed into big waves, dangerous for even the largest bongos. Although those in the habit of navigating the rivers of this part of Venezuela know the signs indicating the approach of the chubáscos, yet boats are frequently overtaken by them before they can reach some friendly bank, so sudden at times is the occurrence of these squalls. I have a very vivid recollection of how our boat was nearly swamped once near 'El Potrero,' one of the finest cattle ranches on the Orinoco. We had stopped for a couple of hours on a marshy stretch of ground to shoot wild ducks, which are abundant at this place. After some very good sport we shoved off well into the stream, so as to get the full benefit of the current. It could not have been more than ten minutes after we had left the shore when one of the men shouted to the others 'chubasco', and with a suddenness that was appalling the squall struck us. Everything around seemed to grow white in an instant. The small drops of rain, which almost blinded us, were of a misty whiteness; the tops of the waves were white ; the very wind rushing past us appeared of a greyish tint. The men bent to their paddles and, as we had not had time to get far from land, we succeeded in getting back. But it was with difficulty that we accomplished this, while most of our effects were wet with the water we shipped in the short time it took us to reach a place of safety. From my experience on that occasion I should 
say that a small boat would have but a poor chance of reaching the shore if struck by the chubisco when far from land.

At ten on the morning of the 8 th we reached the Torno; the place is also called La Puerta del Inferno (The Gates of Hell). At this spot the banks of the Orinoco contract and become bold and rocky. The immense volume of water forces its way through the iron-bound shores which confine it; sometimes boiling and bubbling, sometimes in swift eddies, it pours through the serrated rocks forming the bed of the stream at these gates of Hades. The little 'Caura' trembled in every beam when she struck the first whirlpool. 'Twice she turned almost right round like a cork on the waters, and we were borne back to the 'Gates' by the force of the current. We were more fortumate on our third attempt, but it was slow work getting through this dangerous passage. Above the T'orno the river is again grand and majestic. Our captain kept close to the bank to avoid the current in the middle of the stream, and this allowed us to amuse ourselves by shooting at the alligators basking on the sand, or at the Carreteros which stalked in pairs along the shore. These large ducks owe their name to their peculiar call-note, resembling the hoarse noise of a driver urging his animals forward. I managed to shoot two of them with a Winchester rifle, and we had roast wild-duck that day for dinner. The Carretero is good eating, but it should not be coolied on the same day on which it is lilled, for it is then tough and without flavour. Although alligators are fairly plentiful in the Orinoco, and we saw several and killed some, yet the lower part of the stream is not the best place to kill numbers of these descendants of the gigantic saurians who held sway over the animal kingdom 
in the dim and distant past. On the Apure and the Arauca the killing of alligators for their skins is sometimes combined with the collecting of the feathers of the white egret. The best time to kill them is at night. The hunters visit the swamps and sandbanks, working their way noiselessly through the channels or over the open stretches of shallow water. A lantern with a good reflector is placed at the bow of the punt used on these occasions. The hunters succeed in this manner in getting quite close to the alligators, when they can be shot in a vital spot and secured with a noose or gaff. It is not unusual by these means to procure between sixty and seventy of these reptiles in a single night. When I visited the Orinoco for the first time in 1897, I met two adventurous Norwegians (they were brothers, named Christiansen) who were then engaged in obtaining alligator-skins by the method I have just described. They told me they had followed this pursuit in Mexico before they deeided on trying their fortunes in the land of Bolivar, as Venezuelans sometimes call their country, which happens at the present to be no man's land. ${ }^{1}$ From the Christiansens' description of the alligator-skin industry I have come to the conclusion that it is not by any means as pleasant or lucrative an occupation as being a London stockbroker or a speculator in pork at the Produce Exchange. The wounding and subsequent securing by an uncertain process of an enraged reptile with teeth like a circular saw and a tail like a sledgehammer, is an undertaking calculated to appal even the man who has sufficient nerve to attempt a corner in

1 Venezuela is now being contended for by several generals on the one hand, and President Castro who still holds Caracas and some other towns on the other (August 1902). 
wheat or the recklessness to finance a Spanish-American revolution. Besides, the alligator-skin industry does not end with the night's exciting work in malarial swamps. The skin has to be removed and salted, compared to which the buying and selling of imaginary stocks of pigs' feet before they are put in barrels is clean work. I understand that these skins are worth in New York one dollar apiece, including the cost of the salt. For twenty of these skins, therefore, the alligator hunter can become the possessor of a United States twenty-dollar piece, with the motto 'In God we trust.' He will be able to add in the vernacular of the citizens of the Great Republic, when he comes to know them, 'Everyone else pays cash.'

Captain Mayne Reid, in one of his delightful books for boys, relates how a party of young hunters succeeded in shooting geese at night which were so wild as to be unapproachable during the day. The boys placed at the head of their boat a frying-pan full of blazing pineknots, behind which a section of the thick bark of a tree served as a reflector and also screened the occupants from being seen. With this simple apparatus they paddled down the stream after dark, and were thus able to get quite close to and kill the wary birds they had vainly attempted to approach in the daytime. The method employed in killing alligators I have described is what has brought to my mind one of Captain Mayne Reid's stories which so fascinated me when I was a boy. There are few points more curious in comnection with the habits of the various members of the animal kingdom than the influence a bright light appears to exert at night on almost every form of life. Let us take, for instance, creatures so widely different in every way as fishes and insects. Everyone knows that the surest and easiest way 
to catch moths and many other insects is by means of a light, the brighter the better. Many years ago I used to take great pleasure in accompanying some fishermen who were engaged in the catching of a species of large mullet known to the natives of Trinidad under the name of lébranche. This fish is usually caught by spreading nets at high tide in certain places along the mangrove swamps which line the coast of the island between the towns of Port of Spain and San Fernando. With high water the fish ascend the small channels and wander about amongst the flooded roots of the mangroves, where they find abundance of food. With the fall of the tide, on their return to the sea, they get entangled in the nets set in favourite spots, and thus fall victims to the fishermen's knowledge of their habits. I have referred to this method of catching large mullet or lébranche because it would be misleading to describe the fishing by night only; this latter operation, although affording much sport, being not nearly so remunerative as netting. A dark night in the dry season is the time to go on a mulletspearing expedition with every chance of success. Harpoons and torches are the implements used. Of the men, two to each boat, one paddles and steers at the same time, the other stands in the bow holding a torch aloft in one hand and his harpoon by the shaft in the other. With the rising tide the boats ascend the creeks, to return when the tide changes. The light appears to have the same effect on the mullet as on the alligators, the fishermen being able to get so close to them that they can be speared without difficulty. During my first visit to the Caura in 1897, I observed that the Indians use torches when they go after curassows before daybreak. So that, in introducing here the subject of hunting and fishing by 
torchlight, if I have digressed awhile, yet I have kept in view the principal object of my narrative by describing the habits of the people and other creatures in the country I am writing about, and comparing them with those of other countries.

We had left 'The Gates of Hell' behind us at ten in the morning; we reached Mapire, which is certainly no part of Heaven, at about four in the afternoon. Most of the steamers stop here for the purpose of replenishing their store of fuel, which rarely lasts more than a day, as a supply for a longer period would take up so much space that there would be but little room left for freight. The question of fuel is the great trouble captains of steamers have to contend with on the Orinoco. As a rule, each steamer or line of steamers has its contractors, who are supposed to keep supplies of firewood ready for shipment at different spots on the river's banks. If the owner of any particular stack of wood happens to be in the vicinity of his merchandise when the steamer he supplies arrives, he checks the quantity taken and gets paid either in cash or by an order on Ciudad-Bolivar. But his absence never causes the captain a moment's anxiety. The latter blows his whistle once or twice and allows ten minutes for which he charges no demurrage. Then he sends a part of his crew on shore, who proceed to take in all the wood required. A note is taken of the quantity shipped, more or less, and the steamer tramps contentedly away. Imagine the introduction of this state of affairs into the transactions of the methodical Anglo-Saxon or the still more methodical Gael. Think of a customer walking into the shop of the grocer who supplies his wants, while that gentleman's back is turned, and helping himself to a pound of butter. Go and tell that grocer afterwards that you 
did this thing and took a note of it, and calculate how many cows you would have to pay for if you were at all particular about not going to gaol.

When there is a revolution the wood-cutters find it unprofitable to continue business, so they take a rest or go on the warpath in the expectation of taking something better-it may be a cow or a mule.

Mapire is situated on a bluff commanding a good view of the Orinoco. The country around is open grass-land where a good many cattle are reared, yet the place has the same poverty-stricken appearance which, as I have said before, is characteristic of the towns of the Orinoco. A steamer and three barges were moored to the bank shipping hides when we arrived, and they were still there when we left, for our stay had not been long. By five o'clock the passengers were landed and we had taken in as much wood as it was possible to carry on the deck around the boiler. We then steered for the mouth of the Caura, which is some distance up the river obliquely opposite to Mapire. 


\section{CHAPTER VII}

Humboldt's description of the Caura-Llanos of the Caura-Cattle-rearing -Revolution of 1898-Waterforl-Puerto Antonio Liccioni-Mos. quitos and flies-Maripa and Aripao-Pinta disease-The MatoPiaroas-Cormorants-Ia zona de los bosques.

HuмвоLDT on his return with Bompland from their memorable journey to the Cassiquiare and Esmeralda, refers to the Caura, before which he passed on June 10, 1800. He says that after having slept on an island in the middle of the river, that called Acaru by Father Caulin, they passed the mouth of the Rio Caura. This, the Aruy, and the Carony, he tells us, are the largest tributary streams which the Orinoco receives on its right bank. All the Christian settlements are near the mouth of the river, and the villages of San Pedro, Aripao, Urbani, and Guaraguaraico succeed each other at the distance of a few leagues. The first and most populous contains only about 250 souls. San Luis de Guaraguaraico is a colony of negroes, some freed and others fugitives from Essequibo. This colony merits the particular attention of the Spanish Government, for it can never be sufficiently recommended to endeavour to attach the slaves to the soil and suffer them to enjoy as farmers the fruits of their agricultural labours. The land on the Caura, for the most part virgin soil, is extremely fertile. There are pasturages for more than 15,000 beasts; but the poor inhabitants have neither horses nor horned 
cattle. More than five-sixths of the banks of the Caura are either desert or occupied by independent or savage tribes. The bed of the river is twice choked up by rocks : these obstructions occasion the famous Raudales of Mura and of Para and Paru, the latter of which has a portage because it cannot be passed by canoes. At the time of the expedition of the boundaries, a small fort was erected on the northern cataract, that of Mura; and the Governor, Don Manuel Centurion, gave the name of Ciudad de San Carlos to a few houses which some families, consisting of whites and mulattos, had constructed near the fort. South of the cataract of Para, at the confluence of the Caura and the Erewato, the mission of San Luis was then situated; and a road by land led thence to Angostura, the capital of the province. All these attempts at civilisation have been fruitless. No village now exists above the Raudales of Mura; and here, as in other parts of the colonies, the natives may be said to have reconquered the country from the Spaniards. The valley of the Caura may become one day or other highly interesting from the value of its productions, and the communications which it affords with the Rio Ventuari, the Caroni, and the Cuyuni. Near the mouth of the Caura, between the villages of San Pedro de Alcantara and San Francisco de Aripao, a small lake of 400 toises $^{1}$ in diameter was formed in 1790, by the sinking of the ground consequent on an earthquake. It was a portion of the forest of Aripao, which sank to the depth of eighty or 100 feet below the level of the neighbouring land. The trees remained green for several months, and some of them, it was believed, continued to push forth leaves beneath the water. This phenomenon is the more worthy of atten-

' A toise is equal to $6 \frac{1}{2}$ feet approximately. 
tion as the soil of these countries is probably granite. From the great traveller's remarks it will be seen that he succeeded in gathering but little reliable information respecting this important river. He says that the bed of the stream is twice choked up by rocks: these obstructions occasioning the famous Raudales of Mura and Para or Paru. He makes no mention of the rapids of Piritu between them, nor of those rapids above Para, which are ever so much grander and more dangerous than the famous Raudales of Mura.

At eight o'clock we entered the mouth of the river which the illustrious explorer had passed 100 years ago. The night was dark, and, the river being low, the pilot found it difficult to avoid the sandbanks which encumber the bed of the stream, so that it was almost impossible to obtain any sleep. Just as one would be dozing off there would be a shock as if we had struck a rock. The backing of the engines, the hurrying up and down of the crew, joined to the persuasions of the captain in language which, if not choice, was certainly effective, precluded the possibility of sleep for more than a few minutes at a time. Before daybreak we stopped at the landing-place of the small village of San Isidro. One of our fellow-passengers landed at this place. He had told us that he was the agent of Mrs. Crespo, the wife of the late President, who had been killed in an engagement with General Hernandez's troops a couple of years before, and that he was on his way to take charge of the extensive cattle-ranch ' La Aurora,' one of the finest properties of the heirs of the General.

On the banks of the Lower Caura there are extensive undulating llanos, diversified by narrow belts of woodland, bordering the streams or pools of water. It is a 


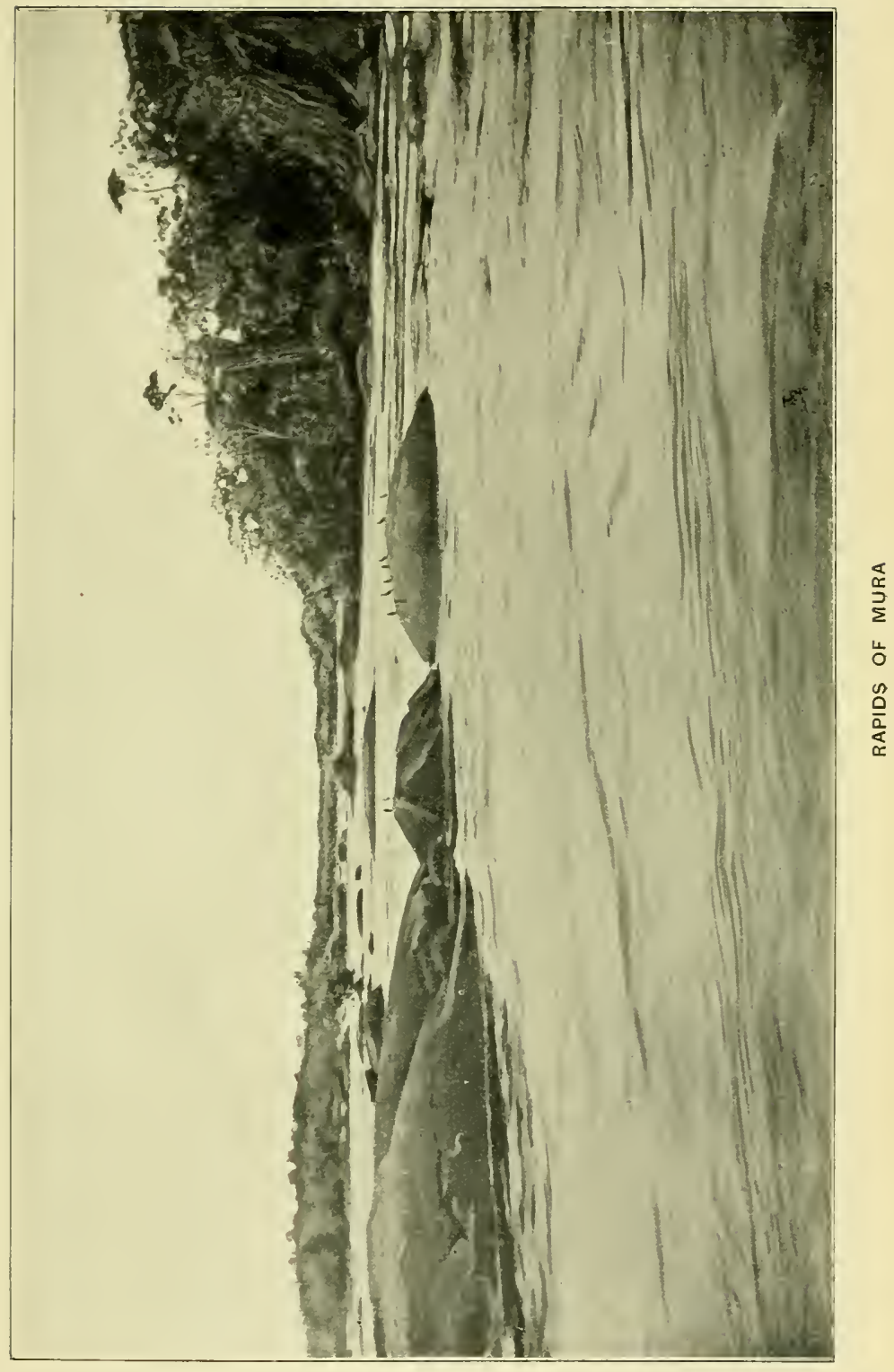



splendid district for cattle-rearing, in a country where cattle and beasts of burden might be reared by hundreds of thousands. But the blasting influence of unceasing strife in a land where revolutions form the stock-in-trade of a part of the people, is the cause why one may pass mile after mile of admirable pasture-land without seeing a horse or an ox. And to think that there is no region where such animals as horses and cattle can be reared at less expense and in greater number than on the llanos of Venezuela!

In the hatos or cattle farms on the Caura, it is customary to have one llanero or cowboy to look after every forty or fifty animals. This is also the proportion of the bulls to the cows, so that each cowboy may be said to be in charge of a kind of animal harem, an arrangement which is sure to appeal strongly to those who have imbibed Mohammedan ideas. The principal work of the llanero consists in attending to the calves for the first few days after their birth, this being the period during which they are in need of most care, especially as they are liable to be attacked by worms while still young and delicate. The weaning of the calves begins at a very early period - that is, two or three weeks after birth. Compared to our milch cows the cow of the llanos produces but little milk, but where there are large numbers of cows, although the individual yield may be small, still the day's supply is considerable. Two sorts of cheese are made on the hatos, queso de cincho and queso de mano - that is, pressed cheese and hand-made cheese; the former, which is manufactured in large quantities, being an article of commerce, while the latter may be looked upon as a delicacy prepared only now and then to meet a limited demand. The manufacture of 
queso de cincho is exceedingly simple. To an arrangement consisting of four poles tied in the form of a square to uprights planted in the ground, a hide is sewn loosely so that it assumes a bowl-like shape. Into this receptacle the milk is poured and a piece of rennet thrown in. The whey having been skimmed off, the curd is kneaded for some time, after which it is transferred to baskets of reeds, where it is subjected to pressure by winding thongs of bull-hide around the baskets in the form of girdles, and tightening them from time to time. Hence the name queso de cincho, the word cincho meaning a girdle. One rarely sees such a thing as a piece of rope on the hatos, the sogas ${ }^{1}$ as they are called, being made of twisted bullhide well greased so as to be pliable. The above is a short description of how stock is reared and handled on a hato like 'La Aurora.' As far as I have been able to judge, the same system prevails over the region of the llanos.

It had been my misfortune to descend the Caura in May 1898, when the news of Crespo's death reached his people at 'La Aurora.' The tonca-bean crop was just over, so that besides the regular inhabitants of the place, there were a good many men at Temblador and Suapure and at the smaller stations on the banks of the Caura, who had come from the surrounding country and CiudadBolivar. They were preparing to descend the river when the steamer 'Apure' arrived with the unwelcome news that a revolution had broken out in the Guarico. It appears that upon the first intimation of a rising the 'Apure' had been taken possession of by the Government, and the authorities, aware of the presence of a large number of men on the Caura, had sent her up on a

1 Soga is a general term for rope, halter, cord; and is also used to designate the lasso. 
recruiting expedition. I happened to reach Temblador from the rapids of Piritu just in time to have my men impressed. Fortunately I managed to arrange with General Rivas, who was in charge of the troops on board of the 'Apure,' to take me and my collections of birds and plants to Ciudad-Bolivar. From Temblador the 'Apure' dropped down to Suapure, where a day was spent recruiting. At night the men, having only their blankets and unable to sleep on account of the clouds of mosquitos, talked and sang and quarrelled until it was time to start. It was a wild lot we had on board. Without discipline, with but little respect for, or fear of their chiefs, eager to get drunk wherever drink could be obtained, excited by the exaggerated accounts of the fighting which had taken place in the llanos, the 'Apure' carried as wild and unmanageable a set of beings as it would be possible to meet with anywhere. After leaving Suapure the steamer stopped at the landing-place of the village of Maripa, and more generals and colonels and troops came on board. The men carried large pieces of meat still dripping with blood, for an ox had been slaughtered and divided up amongst the soldiery. As I had heard the men say when they joined the campaign, 'Now we are going to eat beef,' I understood that they were carrying out to the letter the promise they had made themselves. Wherever the troops stopped they appropriated whatever they could lay their hands on, and as cattle are the mainstay of the plains, the soldiers very naturally looked forward to a pleasant diet of fresh meat free of cost. Few campaigns are carried on at less expense to the leaders than these intestine wars which are the curse of the Spanish-American republics. It is difficult to understand why those who work have put up 
with such a state of things for so long a period. The 'Apure' left the port of Maripa in the afternoon, and crossed over to 'La Aurora,' where a further detachment of men was picked up. They were cowboys from the late General Crespo's ranch, and they had brought their horses with them. Each man had a band of crape around his hat; strips of crape were also tied to the shafts of the lances which they carried. They were typical llaneros, sinewy, and brown from continued exposure in the open savannas. I had occasion when they landed on the banks of the Orinoco lower down, to observe what excellent horsemen they were. When they rode away there was a look of determination about them, and I felt that they meint to fight if any fighting came their way.

While the 'Caura' lay off the port of San Isidro in the early hours of the morning, waiting for the dawn, I could not help conjuring up images of my first eventful visit of September 1897 to May 1898, which had resulted in my spending nearly five months in bed. Once more I was on that almost unknown river, determined to conquer the secrets of the region around its head-waters.

With the first streak of dawn we cast off from the bank and steamed up towards Puerto Antonio Liccioni. The country on both sides of the river is similar to that around Ciudad-Bolivar, the forest region beginning higher up. Along the banks, however, there is a thin stretch of wood which conceals the open llanos beyond. The large ash-coloured heron (Ardea cocoi) is common enough in these woods, where it spends the greater part of the day sitting on some branch at the edge of the river. It is a wary bird, rarely allowing a boat to get within gunshot. Its flight is slow and heavy and its cry loud and harsh; 
it is called locally Garza morena. Another bird which is common on the banks of the river as far as Suapure, is the tree-duck (Dendrocygna discolor). In size, appearance, and many of its habits this duck appears to be closely allied to Dendrocygna fulva, and they are frequently seen together; but while the former bird spends a considerable part of the day perched upon the branches of trees in the vicinity of the swamps where it feeds, the latter does not alight upon any eminence, such as a tree, but remains concealed among the rushes. The call-notes of both of these ducks possess a peculiar metallic shrillness, such as is produced by blowing violently through an ordinary tin whistle, but there is a very decided difference in the uttering of the notes by each species. An excellent decoy whistle may be made by extracting the caps from the brass ends of an ordinary central-fire cartridge and forcing one head into the other. With such a whistle the ducks can be lured to within easy shooting distance of the sportsman, and if the flock be not an exceedingly wild one, the birds will return repeatedly in answer to the call. I have been assured by native hunters that the tree-duck is in the habit of laying its eggs in some hollow stump of an old tree. When the young are hatched the parents force them out of the nest, taking care to make them fall into the water beneath. The large black duck (Cairina moschata) or Pato real, is also a lover of trees. It perches frequently during the day, and repairs late in the afternoon to some particular tree where several individuals meet to pass the night.

At nine the 'Caura' reached Puerto Antonio Liccioni. A long shed-building covered with galvanized iron, with a few mud houses with thatched roofs scattered around, constitute the station. It is only a few years since the place 
came into existence. The store was built by Mr. Aurelio Battistini, a merchant of Ciudad-Bolivar, who named it in honour of his father-in-law, Don Antonio Liccioni, for a long time chairman of the famous Callao mine. A steam rice-mill is attached to the store, the inhabitants of the Caura being now largely engaged in the cultivation of this grain. Before the erection of the mill, the wasteful and tedious process of pounding the rice in a wooden mortar was the method employed for removing the husk from the grain. The winnowing was done by slowly pouring the mixed husk and grain from baskets held high up on to mats placed on the ground, the wind doing the winnowing. Now most of the growers bring their rice to the mill for preparation. Puerto Antonio Liccioni is cursed with sand-flies, so is the lower part of the Caura from Suapure to its mouth; but it is a singular fact that this small sand-fly, the sting of which causes so painful an itching, is not met with above Suapure, although it is a perfect plague lower down, and on the banks of the Orinoco. Many different species of mosquitos and other flies are plentiful in the forest region beyond the village of Suapure, but this terrible little pest is fortunately never met with. The natives use the word mosquito for both gnats or sand-flies and mosquitos without distinction, but in designating the mosquito specifically they never employ any other word but pullon.

The myriad of flies of different kinds which infest the whole forest region, especially during the rainy season, are simply called plaga - the plague. Mosca is generally applied to the house-fly alone. Whenever we spoke about mosquitos, I tried to explain to the people of the place the theory of malarial fever in connection with these insects as propagators of the disease. Of course, it would 
have been waste of time to have gone into details respecting the disease in the form of microbes, and its transmission from one being to another, as in the case of malaria, in the shape of plasmodia, so that my explanations had to be of a character which they could assimilate. They usually appeared to be very much surprised at the theory, but they almost invariably agreed that the period during which malaria was prevalent coincided with the presence of certain kinds of mosquitos.

A walk of three-quarters of an hour across the llano takes one to Maripa. Nearly all the inhabitants of this place and the neighbouring village of Aripao are pure negroes. The fact is worth mentioning, because the black race does not by any means constitute so large a proportion of the inhabitants of Venezuela as it does in the West Indies and in the Southern States of North America. I was told that these negroes of Maripa and Aripao are the descendants of one of the few batches of slaves introduced into the country before the abolition of slavery. The republics of South America, with the exception of Brazil, do not appear to have given much encouragement to the African slave-trade. It is not that the Spaniards were more humane than the other Europeans who followed in their footsteps, and finally wrested a part of their possessions from them, for they also made use of African slave-labour in their West Indian colonies, but on the mainland they probably obtained all the workers they had need of from the conquered tribes who owned the country before their advent, so that there was no necessity for importing slaves from a foreign country.

The negroes of Maripa and Aripao possess all the features of the races from the Slave Coast; they have the 
heavy expression, the thick lips, the yellowish tinge of the whites of the eyes characteristic of the tribes from Western Africa. During the tonca-bean crop they are engaged, like most of the inhabitants on the Caura, in the collection of sarrapia. At other times they attend to their provision gardens, or are employed cutting wood, principally cedar, of which there is an abundance in the extensive forests of the district.

I have never visited any spot where ulcers of a virulent and almost incurable type are more common than amongst the dwellers on the Caura, although skin diseases in general are far from being rare in tropical American countries. At least every second man and woman one meets is a victin to these terrible sores, and the blacks of Maripa and Aripao do not enjoy any immunity from what could almost be called the national complaint. Probably personal habits as regards cleanliness have much to do with the prevalence of llagas, as these ulcers are called. In addition to the absence of cleanliness and care, particularly in the early stages of the disease, when the small sores are curable, there is the question of diet, which is of so much importance in connection with this disorder and others of a similar nature. There is so little change in the food of the people of the Caura, and it is so coarse in quality, that it is a marvel how they can continue to subsist, year after year, on so poor and unvaried a regimen. Dried beans and rice simply boiled in water with a little salt, form the principal nourishment of the peon. Fresh meat is rarely obtainable; the beef which is used, being roughly salted and dried in the sun, is unpalatable and indigestible. With such poor food, with the inordinate consumption of freshly distilled rum which is generally taken raw, is it 
any wonder that the inhabitants of a hot damp climate, teeming with insect life, should be subject to ulcers and kindred diseases? A not uncommon form of skin affection which I noticed, particularly among the negroes of Maripa and Aripao, is the pinta disease, or spotted sickness. I did not observe any cases of the black and blue forms of the disease, the white and pink varieties being the only ones I had the opportunity of seeing. The common term applied to pinta in Venezuela is carate; those afflicted with it are called caratosos. The same causes which contribute to the prevalence of ulcers among these people are no doubt responsible for the existence of this disfiguring affection.

Fortunately, the disease, like many other cutaneous disorders, does not appear to be attended with any symptoms dangerous to the health of the individual affected with it; its only drawback being its grotesque unsightliness. Probably it is exceedingly difficult to cure, but as a rule no attention is paid to its existence by this apathetic people, nor are any attempts made to get rid of a malady which, though repulsive in appearance, does not entail any suffering.

In strong contrast with the lightness with which any one affected with carate loolis upon his affliction in this out-of-the-way place, is the dread with which it is regarded by the inhabitants of the larger towns of the western plains, where it appears to be common. Sarare, a town of importance in the state of Zamora, bears the unenviable distinction of breeding more caratosos than any other spot in Venezeula, although it is common enough in Barquisimeto and other towns of the west. There is a firm belief among the people of these places that carate is not transmitted by simple contact; they 
think that it is necessary to introduce blood from a caratoso into the system of a healthy person so as to ensure the development of the disease. So rooted is this conviction, particularly among the lower orders, that a common threat one hears in a street quarrel, is, 'Te voy a pintar '- 'I shall paint you.'

Although it had been arranged at Ciudad-Bolivar that there should be no delay at Puerto Antonio Liccioni, and that we would find everything in readiness for an immediate departure from that place, it did not cause me any disappointment when I learnt that the men whom we required could not start before the following day, Monday. In fact, I was prepared for even a longer stoppage, so that on the whole I considered we had reason to congratulate ourselves. Mr. Klages, an American collector of birds, butterflies, and mammals, spent the day with us. He had been nearly three years at Maripa, he told me, and he was delighted to meet with some Englishspeaking people. That night was to be our last on board. On the morrow we would be cut adrift from all communication with the civilised world: we would have left behind us many luxuries and many pleasures, yet I looked forward to my trip up the river with keen delight.

The noise of the stokers getting up steam awoke us at an early hour-it must have been about three. I dozed off again to be aroused by the screech of the steam whistle, which, as had been agreed, would be a signal for the men on shore that we were ready to start.

More than an hour elapsed before two of them put in an appearance; they were very drunk. It was nearly eight when the rest arrived, the whole of them in an advanced stage of intoxication. All this time the captain had been alternately pulling at the throttle of his whistle and 
swearing in approved nautical fashion. He reviled all peons in general and those of Puerto Antonio Liccioni in particular; but the men, who had had a night of it and were in good humour with themselves and everyone else, only laughed at him. As one of them told me afterwards: "How could anyone expect that they would go on a long and dangerous voyage without bidding good-bye to their friends, and could there be a jovial parting without rum? Did not the captain himself get drunk at times?' He politely hinted that I was no man if $I$ did not also indulge in an excessive libation now and then. I admitted that his arguments were sound and to get drunk at times was a glorious sensation. Any other logic would have been lost on him.

At ten o'clock we passed Suapure. There is a pronounced bend in the river, which is both broad and deep, towards the east, just above the village. At this spot it receives one of its three imiportant affluents, the Mato, and this tributary is navigable for small dug-outs for a considerable part of its course. Two of the Indians who were with me in 1897 and 1898 told me that they had ascended it for ten days and that it was still navigable when they turned back. They said that game was plentiful on its banks and that its waters were full of fish and turtles. The Mato rises in the Serrania de Mato, near the country of the Piaroas, small bands of whom have, during the last two or three years, paid regular visits to Suapure in quest of bits of iron for their arrow-heads, and such other trifles as they can obtain. It is said of these Piaroas that they make mummies of theirdead which they put into large earthenware jars, but I have had no opportunity of seeing any such mummies. inyself. The Mato brings down a quantity of sand and 
logs of wood, and this débris has accumulated near its mouth in the form of an extensive bank. When I ascended the river in the February of 1898 , and passed near to this sandbank, I witnessed an extraordinary spectacle. For over a mile in the water on each side of this stretch of sand, and sitting on it, were myriads of that dark slate-coloured cormorant (Phalacrocorax vigua) called Cotua by the natives. I had seen immense flocks of this cormorant at Cumaná, for it is plentiful on the north coast of Venezuela, but never before had I beheld such a multitude of birds assembled in one spot. In the vicinity of the town of Cumaná, a narrow arm of the sea, separated from the Atlantic by a range of arid hills, runs inland as far as the village of El Muelle. It is called the gulf of Cariaco and it swarms with fish. It is in consequence a favourite resort of the Cotua, which can procure a sufficiency of food for it's countless numbers only in parts of the sea and in such rivers as are stocked with a superabundance of fish. The fishermen of Cumana and of the neighbouring island of Margarita, who have ample opportunity of observing the Cotua, say that they have never met with its eggs; but as there are many inaccessible cliffs in the neighbourhood of these localities, some such spots may be made use of as breeding-places. Perhaps one or two of the many rocky islands of the Caribbean Sea serve this purpose; perhaps the birds migrate to some recess far away in the north where they have their regular nesting seats; perhaps they cross the Isthmus and rear their young on some solitary islet in the Pacific. It has been observed that there are not nearly so many Cotuas along the coast of Venezuela during the northern summer months as at other times of the year, so that in all likelihood the birds wander away in warm weather, to return when 
the cold sets in. Like other varieties of the family this cormorant congregates in vast flocks. Abundance of fish in favoured parts of the sea may be the cause of their being so gregarious, but they may also have found by experience that they gain some advantage by fishing in company; for any shoal of fish attacked simultaneously by a large number of birds would offer in their bewilderment an easier prey than if pursued by one or two individuals only.

When I saw the clouds of these Cotuas which rose from the surface of the Caura while we were passing the mouth of the Mato, and I considered that each of these greedy birds devoured several pounds of fish in the course of a single day, I could not but appreciate the necessity for that prodigality of generation with which Nature has endowed many of the dwellers in the waters.

Most of the men who accompanied me ate the flesh of this cormorant, although it possesses a disagreeable oily taste which is most unpalatable. But then, some of my peons were as voracious as the cormorants themselves, with the difference that the former were omnivorous.

At a distance of about a mile above the mouth of the Mato a ledge of rock runs across the bed of the Caura, and as there is a slight declivity at the spot, the current is rapid. But between this rocky formation and the settlement of Temblador no obstruction occurs in the bed of the stream, which is broad and deep, and free from rocks. The country on both banks is clothed with virgin forest. It is 'La zona de los bosques,' the region of the woods. We had entered its outskirts; we meant to penetrate some distance into its solitudes; we should see 300 or 400 miles of it along the banks of the Caura. But even then we should have wandered on its threshold only, 
for it stretches away to the Amazon and far beyond, enclosing the banks of the mighty tributaries of the mightiest of rivers; spreading over the highlands of Brazil to the deserts of Bolivia, and the pampas of Paraguay ; clothing the slopes of the snow-crowned Andes, it covers with the luxuriance and immensity of its growth a considerable portion of the South American continent. Who can hope"to violate the seclusion of its impenetrable recesses? 


\section{CHAPTER VIII}

Temblador-Departure for La Prision--La Prision-Ants-Our quartersMethod of keeping accounts-House building.

ALTHodgh it was quite late in the day when we got opposite to Temblador, we hoped to be able to land our effects before nightfall; and had our captain adopted the usual tactics of the average Orinoco pilot, there would have been no delay in putting us and our belongings on shore. We had not taken our skipper seriously, when, with much ceremony he had see-sawed into Mapire, nor had we looked upon his throwing the lead near to Puerto Antonio Liccioni otherwise than as a joke meant for our amusement. Now that we were in a hurry to get on shore before nightfall, I for one expected him to take into account the emergency of the case and follow the rapid and effective method of running ashore, which is the custom in the navigation of the Orinoco. Long may it survive! I have heard it said that now and again a sharp rock will find itself in the way of an over-adventurous steamer, and the owner has to build a new one; but in spite of this disadvantage for the owners of steamers the system of charging the shore has much to commend it so far as passengers are concerned, and saves a good deal of vexation of spirit. However, it was not ordained that we should enter Temblador in this fashion, which precedent has rendered orthodox among the mariners of the river. It was with all the pomp and vanity of a 
liner that the little 'Caura' was slowly laid up against the steep patch of sand leading to the houses which form the settlement. On the way, when time had hung heavy on our hands, we had been greatly amused at the marvellous evolutions which our skipper had practised when he had had to stop anywhere. And when at Cucurital he had covered himself with glory by attempting an original mancuvre, which had resulted in his running into a stack of firewood at the water's edge and ramming a part of the wood into the river, our joy had been boundless. Now, with that contrariety of spirit characteristic of most human beings, we felt quite vexed with him over this strange hobby of his of handling his launch like a ten thousand ton liner, and we fretted at the delay which had been but a few days before the source of so much amusement to us.

By the time the 'Caura' was securely moored, and what the mate called the 'bridge' run out, it was quite dark. If the captain had taken his time in getting his ship into port he was determined to make up for the loss of it by bundling us on shore. No sooner had we balanced ourselves across the three-inch plank I had heard called the bridge, than the jettisoning of our property began. Luckily the landing-place at Temblador' is of soft powdery sand, otherwise we would have been saved the trouble of carrying away a goodly portion of our effects. It took me over two hours to reduce to something like order the state of chaos which the casting ashore of our chattels had produced. It was with a feeling of relief that I recognised the box of dynamite for which I had searched in vain since leaving CiudadBolivar, and which had caused me so much anxiety. When I had seen that the pile of boxes and odds and 
ends, indispensable on a long journey, were properly covered with oil-cloths in case it should rain, we ascended the hill where the houses are situated. There was a sound of revelry in Monteverde's compound, which ceased for a moment as Longacre, Jacobson, and myself entered. After I had gone through the bear-like ceremony of backpatting which is the mark of affection bestowed upon an old friend, I introduced my friends in the impressive phraseology so dear to the descendants of the old Spanish hidalgos. The people of the house insisted on our taking possession of the few seats which was all the furniture they could boast of, and coffee was handed round.

The Joropo ${ }^{1}$ interrupted by our arrival was started afresh, and as there was only one girl to dance with, the men stood around the room and danced by turns with this sole available female performer, who seemed indefatigable. I chatted with Monteverde about the events which had taken place since my departure in 1898, but he had little to tell. One of his men had died; Roseliano had lost an eye while cutting down a tree; the tonca-bean crop had been fairly good, therefore there would be no yield to speak of in the coming season; they had all suffered from fever, but that was no news; and so he rattled on about the few occurrences which had lent some variety to his monotonous life in this secluded settlement. We did not remain very long at this ball, where one girl did the dancing around mud walls adorned with male wallflowers. Our hammocks had been slung in a long open shed adjoining the ball-room. To the thrumming of the cuatro ${ }^{2}$ and the angry drone of a cloud of deluded mosquitos beating against my hammock-net I fell asleep.

1 Joropo, see note page 71 .

" Cuatro = a stringed instrument. 
At daybreak coffee was brought us. Wherever one stays for the night in the country districts of Venezuela coffee is given in the morning and no payment is expected. Indeed, any offer of money for board or lodging would be considered an insult in most homes; but a small present may be made to one of the children without hurting the susceptibilities of these hospitable people, who are always glad to share whatever they have with the stranger staying with them.

While the boats were being got ready for our departure for La Prision, I strolled about. No change had taken place since my last visit. In the kitchen the same woman was grinding the corn for breakfast between two stones, as she had done three years before, while the pigs trotted about in the hope of being able to steal something, and the fowls, dogs, and cats added to the general confusion in this sort of stationary Noah's Ark.

At eight o'clock the men came up to the house and said that they were ready to start. The cargo had been put into three of the bongos. The largest boat I decided to leave at Temblador; it would have been dangerous to have attempted the passage of the rapids in such an unwieldy construction. With a small boat the journey to La Prision takes about three hours, but we were nearly five hours paddling up against the strong current before we got to the stretch of rocks which encumber the Caura for 300 or 400 yards below the landing-place at La Prision. Getting through the narrow channels of this part of the river when the water is low, is tedious and even dangerous. WVe had almost reached the port, when our men, while crossing the last chammel, allowed their bongo in a moment of carelessness to be driven sideways against a large slab of rock. In a few seconds 
our boat was half full of water and it looked very much as if we were going to lose her and her cargo. The men jumped overboard and managed to get her off, but nearly all of our things had got wet, and this, to say the least of it, was a serious inconvenience. The other boats were not yet in sight, so I walked to the house alone, leaving the men to spread our effects out to dry. I was no stranger at La Prision. It was in the forest around the settlement, and at the rapids of Mura close by, that I had collected most birds in 1897 and 1898; and although I had on that occasion frequently been away for several days, and once for three weeks, yet I had on the whole spent more time at La Prision than anywhere else. I must have created a good impression during that first visit, for my return appeared to be the cause of genuine pleasure at the settlement, and vigorous was the back-patting and bear-hugging with which these hospitable people emphasised the extent of their joy at seeing me. Word was sent to the farthest houses that I had arrived. The backpatting and bear-hugging had to be repeated with each batch of arrivals, until I felt like a wrestler who had been having a hard half-hour with a heavy antagonist. Arrivals are not everyday occurrences at these settlements, but such a coming as ours was an event in the history of the place.

In the height of the confusion brought about by my home-coming, as Doña Antonia was pleased to call it, the other boats arrived with Longacre and Jacobson. They also had met with a mishap, and a part of the cargo of one of the boats had got wet. The presentation of these new arrivals to the lords of the soil occasioned great excitement and bustle. The pigs and dogs joined in the demonstration, and as they were anxious to make us 
understand that they took an intelligent interest in the proceedings, they tried to complicate matters by getting between our legs and making us look ridiculous. Somehow the scene reminded me of the sort of thing which must have happened when the prodigal son returned to the paternal homestead. But although the parallel ceased at the part where the fatted calf came in, we had no reason to complain. An obese centenarian of a land-turtle was sacrificed for the occasion; and what veal can compare with the succulent flesh of this Chelonian! My men took up their quarters in the large shed where the boiling of the cane-juice for the making of the coarse sugar known as papelon had been performed during my first visit. It was there I had stayed, and I had good reason to remember the place. Attracted by the syrup with which the ground had become saturated, many species of ants had taken possession of the scrub around the shed, from which they made excursions at night in search of this favourite food which was there in such abundance. During the day not an ant could be seen, for the little robbers had doubtless found out that there was danger while the huge animal which made the honey they loved so well was walking about, so they waited until nightfall to commit their depredations. Then they poured forth their millions and we got the benefit of their attentions if we attempted to leave our hammocks. Now all this was changed. A new boiling-house had been built, at some distance from the old one. The ants, accustomed to a life of indolence and luxury, had suffered a great deal of inconvenience for many days after the removal of the industry upon which they depended for their existence, but they had, according to their custom, sent out spies who succeeded in locating the new Goshen, and then in 
one day they migrated in a body from their home near the old boiling-house, so suddenly struck by famine, and took up their abode close to this other land flowing with honey, so that on this occasion my men did not have to dispute the possession of the premises with an army of ants. Longacre, Jacobson, and myself accepted Doña Antonia's hospitality. Hers was the best house at the settlement, and we made ourselves as comfortable as we could under the circumstances. Within a few feet of our quarters was the kitchen, the most important part of a rancho. Here the women spend the greater part of the day and take their meals. I have never seen women of the peasant class in the country districts sit at table with the men. Most of the work at La Prision and the other settlements where I have stayed falls to the lot of the females of the family: and this is all the more tedious on account of the absence of any implements for facilitating manual labour. Even so necessary an article as an ordinary grinding-mill is rarely seen in any household. Coffee, corn, and the coarse salt used in the country are ground upon a large flat stone which with time gets hollowed out. Cakes made of Indian corn are the bread of the peasantry. The making of these cakes, or arépas, as they are called, is tiresome work, occupying a good deal of the women's time. After pounding the corn, damped with water, in a large wooden mortar so as to get rid of the skin with which each grain is covered, the slow process of triturating the coarse bits until the whole assumes a soft consistency, is performed. The mass is then kneaded in thick cakes, which are baked over the fire. When the women are not cooking they do a little sewing or wash the clothes of the household.

What strikes one most forcibly while travelling through 
Venezuela, is the total absence of comfort in the homes of the people; and this is not confined to the poorer class of peasants, for men of means, owning large cattle hatos or coffee-plantations, are content to live in the same miserable manner. A rough table, a bench, a few plates, perhaps a glass, the hammocks of the family : that is the entire furniture of the home of a man like Medina, who owns more property than anyone else at La Prision. Not a single person at this settlement could read or write. Once every two or three months a sort of travelling scribe visits the place, and stays for a few weeks answering letters and arranging accounts. During his absence notes of the transactions between Medina and his peons are kept by a system of symbols peculiar to the place. I was much puzzled during my first visit by the coal marks which disfigured the posts of the house. These consisted mostly of long and short bars, and other irregular characters. By degrees I managed to master the significations of most of these symbols. Each post was devoted to a peon-was in fact his pass-book. A long bar meant a day's work, a short one half a day; the other strange characters represented the coffee, beans, salt, and other necessaries with which he was charged. Five thousand years have passed away since a similar system did duty in Egypt and Assyria. To-day, in its most primitive form, this system of symbols meets the wants of these inhabitants of a secluded part of South America.

The houses or mud huts in which these people live are built on the same principle as those met with all over Venezuela and Colombia. Not a single nail is used in their construction. Whenever any fastening has to be performed it is done by means of creepers procured in the forest. The word bejuco is applied to all creepers without 
distinction, and although several kinds of bejuco are used in house-building, there are a great many varieties quite unsuited for this or any other purpose. When creepers for construction are not obtainable in the neighbourhood of a settlement, they are brought from a distance, and they then constitute an article of commerce. On the Caura the two kinds of bejuco most commonly employed in building are called Mulato and Murcielago. The former belongs to the family of the Aroideæ, the latter to that of the Bignoniaceæ. In the case of the scandent Mulato, the long roots, after having been cleared of their thorny bark, are usually thick enough to allow of being split into two or four strips. Both kinds are soaked in water before being used, so as to render them pliable. In this region of the woods the construction of a hut or rancheria is a simple matter. All the necessaries are abundant in the forest adjoining the clearing, the only cost being the labour of procuring them. Very often the huts are simply thatched sheds having a part at one end enclosed with palm-branches. It is customary, however, to form the enclosure to which the family retires at night by tying poles close together to the uprights and plastering them over with mud. In such easily constructed huts these people pass their simple lives arvay. Having but few wants, unacquainted with luxury, satisfied with getting drunk whenever they can afford it, they are content to live as their fathers and grandfathers have done before them; they have no longing for a more civilised form of existence. 


\section{CHAPTER: IX}

\section{LA PRISION}

Manufacture of sugar-Method of packing-Molasses and stills-TradeCabbage palm and grub-Faculties of insects-Hunting and fishingFishing with dynamite-Rise and fall of the Caura-Voracious fishIn dreamland.

THE clearing at La Prision is fairly large, and is planted principally in rice, sugar-cane, and tobacco. Bananas, cassava, sweet potatoes, yams, and corn are grown in sufficient quantities to meet the wants of the people. From the sugar-cane a good deal of the coarse brown sugar known as papelon is made. The cane is crushed by vertical rollers worked by cattle in the very crudest fashion, the mill being the property of Jose Gregorio Medina, who also owns most of the land under cultivation. It is indicative of the lack of ideas on the part of these people that a man was employed during a considerable part of the day carrying the cane-juice in a large calabash from the trough near the crusher to the boiling-place. The simple expedient of a piece of bamboo for running the juice to the cauldron had never been thought of, although it was immediately put into practice when I suggested it. The juice is boiled in cauldrons, quicklime being added from time to time to assist in thickening the syrup, which is transferred when it begins to harden to shallow wooden troughs, where the lumps are broken up by means of paddle-shaped pieces of wood, and the whole 


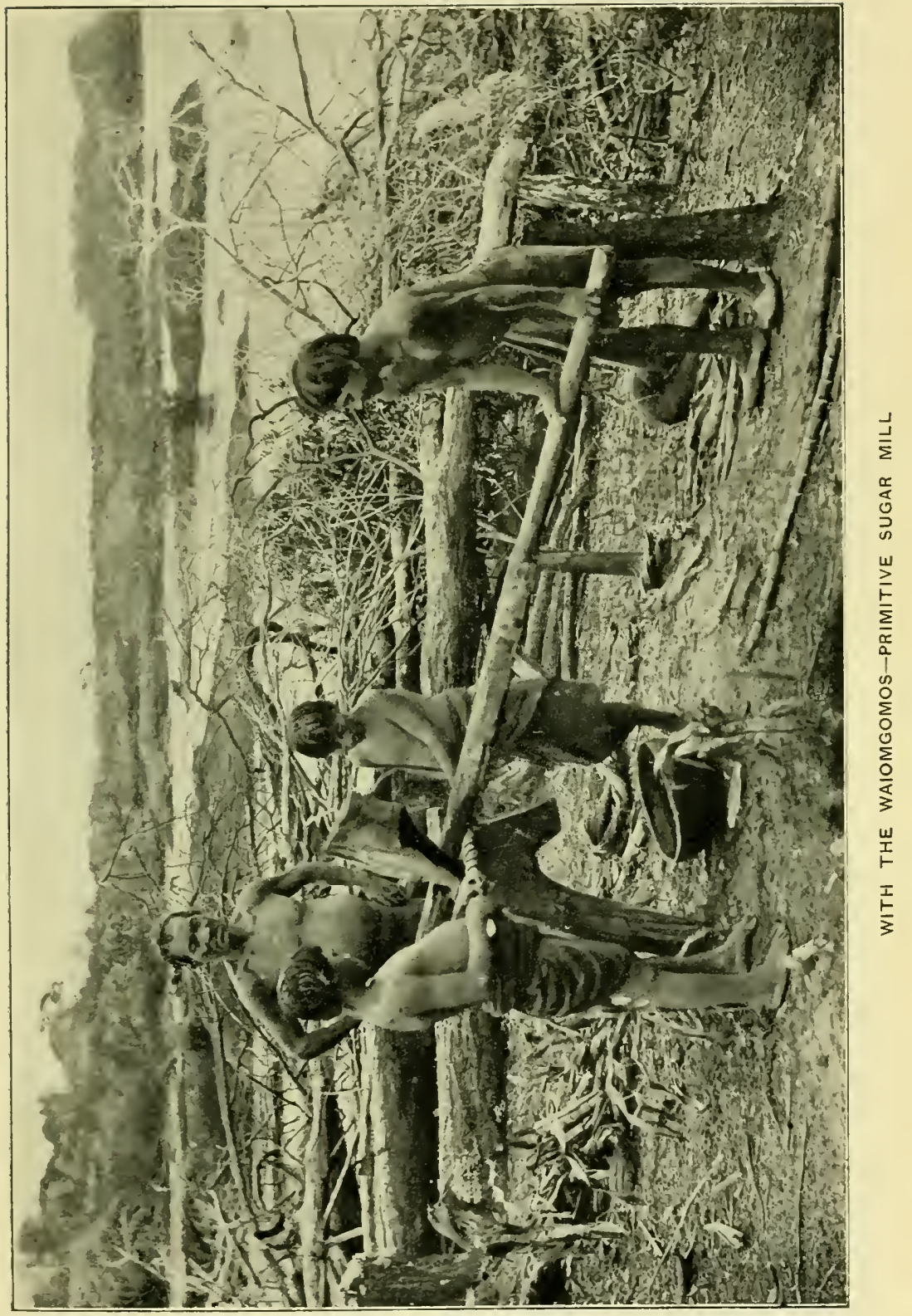



mass thoroughly mixed until it is of the consistency of thin mud. The troughs are then emptied into earthenware moulds placed head downwards in holes in the ground. When the sugar has cooled and become solid the moulds are taken out of the ground, and as they are conical in shape the sugar drops out of them in the form of a loaf when they are turned over. These are the papelones or common sugar-loaves one sees everywhere in Venezuela. They are of different sizes and according to the size so many, it may be thirty or forty, go to the cuenta. ${ }^{1}$ Papelones are put up in the following manner: Pieces of a fairly thick creeper of a given length are bent to form a circle, the ends being spliced with strips of bark. Similar strips are then woven in large meshes across each hoop. Several kinds of bark are used in Venezuela for this and various purposes. From the majagua (Hibiscus tiliaceus), which is common in many parts of the country, good cordage is made. In the northern mountain range, where all the traffic is performed by pack animals, the trappings of the donkeys and mules are usually plaited from the bark of this hibiscus. The word majagua is used indiscriminately in speaking of the tree or the bark obtained from it. On the Caura two sorts of bark are employed; one is called coco de mono (Chytroma rosea), the other cabeza negra (Apeiba Tibourbou). These barks, being pliable and strong, are put to many uses by the Indians and Venezuelans. Besides papelones, such articles as cassava and dried fish are always packed between these sieve-like affairs of creepers and bark, which are really very handy appliances, easy to make and effective in use.

1 Many articles are sold in Venezuela by the cuenta. A cuenta is a pack: ze of a particular size, containing a fixed quantity of some particular artic :; thus one hears of a cuenta de cazabe, or a cuenta de papelones. 
One of the hoops is placed on the ground and covered with a layer of dried banana-leaves. On this the commodity to be packed is arranged in the most convenient manner, and more banana-leaves having been spread on the top and sides, another hoop is placed above and lashed securely to the one beneath. In a country like Venezuela, where the necessaries of life have frequently to be carried from one district to another, sometimes over considerable distances, on the backs of mules and donkeys, we cannot but admit that these primitive packages are admirably suited for the uses to which they may have to be put. Any two such packages are ealled a carga, literally a load, one being fastened on each side of the rough pack-saddle used in the country so that the packages balance each other.

At La Prision, as everywhere else where sugar is made, there is always a part of the juice too poor in saccharine matter to crystallise. This is made into molasses, which is stored in large wooden troughs hollowed out of some huge tree. After the trough is filled with syrup bits of wood are laid across the top and the whole plastered over with clay, which is allowed to harden. In this manner a quantity of molasses may be kept over from one season to another. Without these precautions the molasses, exposed to the atmosphere, would soon turn sour. In any case, were the troughs not properly covered over, it would not be long before they would be full of all sorts of insects. I recalled to mind, in connection with the molasses' branch of the sugar industry at La Prision, that when I made Jose Gregorio Medina's acquaintance in 1897 he had a grievance: he did not own a still, or as he called it in the language borrowed by his forefathers from their Moorish conquerors, an alambique.' Day after day

1 Arabic, Alanbiq. 
for two whole months during which I was his guest, my friend Jose Gregorio would pour doleful jeremiads in my ear because he was not the possessor of a still. No work of human hands, and he had been to Ciudad-Bolivar and had seen the river steamers and the ice-factory, appeared to excite his admiration to the same extent as the invention for turning harmless molasses into the fiery liquid that makes some men foolish and happy, and others quarrelsome and murderous. Without rum no. fiesta ${ }^{1}$ is possible in Venezuela, and as Jose Gregorio used to say, one may pay his peons off on feast-days if he only happen to have a still. 'And to think,' he told me pathetically, 'that I managed to get an alambique after you left in 1898 , only to lose it the first day we made rum.' Then he related how the Virgin had lent an ear to his earnest prayers, and had blessed La Prision with an abundant tonca-bean crop. He had gone to CiudadBolivar and had bartered his beans for a small distilling apparatus. After weeks of navigation against the strong current of the Orinoco and the still stronger one of the Caura, he had at last had the satisfaction of mooring his bongo with its precious cargo to the old tree which is the anchorage at $\mathrm{La}$ Prision. To the thrumming of the cuatro and the singing of extempore verse in honour of the occasion, the alambique was installed in a corner

1 Usually a day dedicated to some particular saint. Anyone who is sceptical on the subject of saints would do well to consult a Spanish calendar. Such \& one will be surprised to learn how many authentic saints have lived and died within the last 1900 jears. The days dedicated to the more important saints are public holidays. As a result of this arrangement scarcely a week occurs during which it is possible to get men to work for six days consecutively. The memory of the deceased gentlemen who have been canonised is preserved by gambling and drinking. In a country where killing is not murder, and no capital punishment exists, most of the killing takes place on feast-days. 
of the mill-shed. On the very first day that distilling operations were started the catastrophe occurred: the mill-shed was burnt down, involving the still in complete. ruin, the peon who was in charge of the place having been rescued from cremation in the nick of time. The poor devil tried to explain how he had been overcome by the fumes of strong spirit and had fallen into a state of dreamy unconsciousness with a lighted lamp, which had caused the damage, beside him. Medina ably backed up by the others very uncharitably decided that the brute, as they called him, had got drunk, and they exiled him from his beloved La Prision in the arbitrary manner displayed by Augustus in dealing with the poet Ovid, whose legacies of Metamorphoses in rhythm caused so many of us to get into trouble in years gone by while rendering financial service to Bohn's Classical Library.

Besides being the owner of the mill and most of the land under cultivation, Medina has the monopoly of trade at La Prision. From time to time he sends a bongo or two loaded with rice, papelones, or molasses to Puerto Antonio Liccioni, receiving in return cheap cotton goods, dried beef, salt, and such other necessaries as are indispensable; luxuries are rarely seen at these settlements. These commodities he sells to the peons-who are all indebted to him-at an enormous profit, and they repay him by keeping up the cultivation and working at the mill. It is customary all over Venezuela, except in the larger towns, for the peons to sit at the same table as their employer, a part of whose engagement is to feed them while they are working for him. As a result of this arrangement the food one sees on the patriarchal dinner-tables of the land of revolutions is not of a kind to tempt a jaded appetite. It is considered the height of 


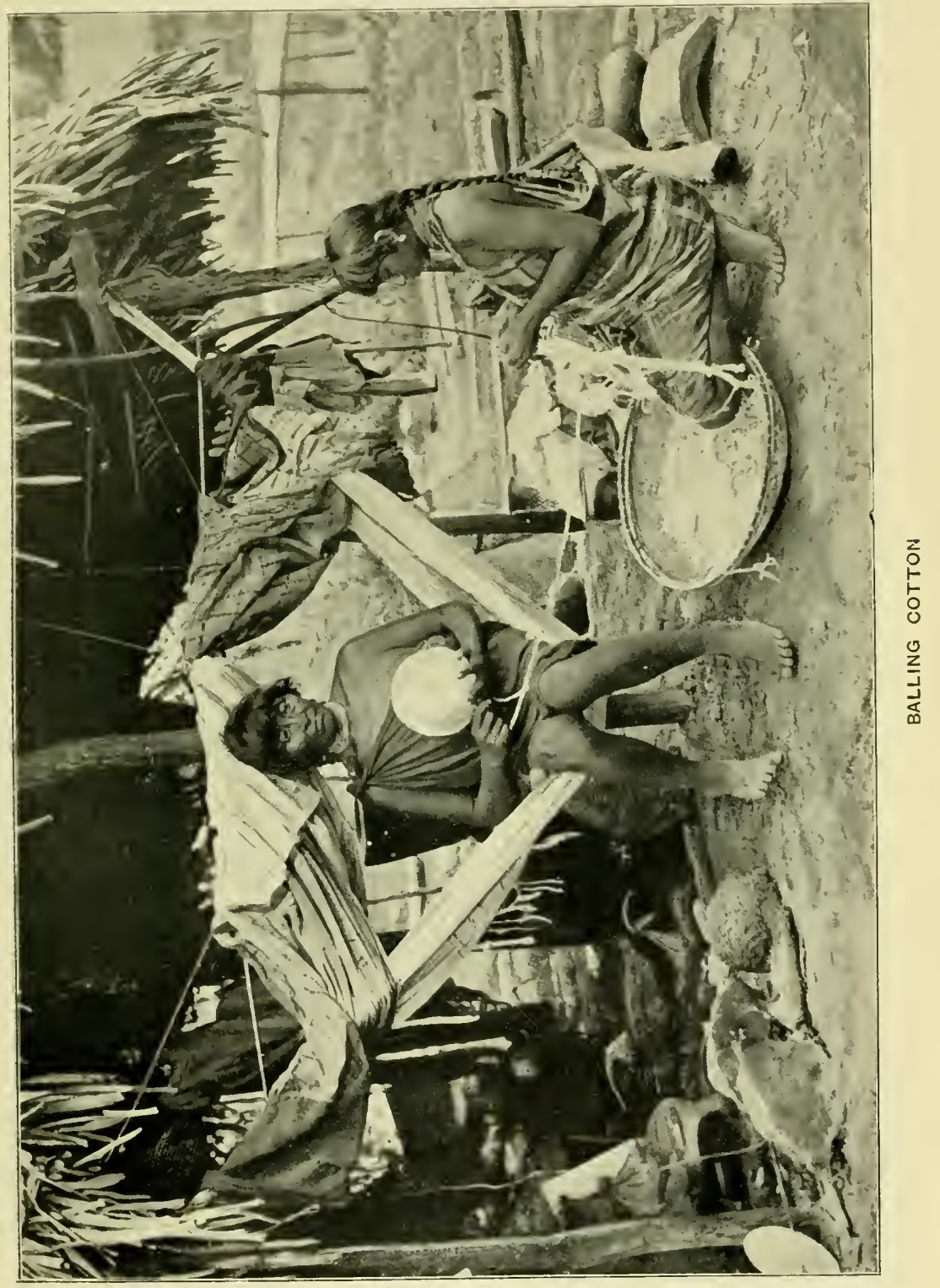



bad breeding when anyone enters a house during mealtime, or even passes before the door, not to invite him to share the family repast. The invitation is more often refused than accepted. There are times when this extreme courtesy has its disadvantages, for now and again a hungry crowd, regardless of etiquette, takes the host at his word, and he finds himself face to face with the performance of a miracle like that of the loaves and fishes. But no basketfuls are cleared away after such a feast, nor does the multitude disperse having eaten its fill.

I was surprised to learn that the people at La Prision were igmorant of the fact that several members of the palm family supply food, although many palms exist in the forest around. In Trinidad and other places two delicacies are obtained, chiefly from the stately palm known as the cabbage palm. The heart of the upper part or crown, which is in reality the leaf in embryo, furnishes a vegetable, while the rest of the tree nurtures a grub considered by those accustomed from early youth to see these unsightly grubs at table, one of the daintiest of delicacies. To such an extent is early training responsible for our prejudices in after life, that I have known people who would dine off semi-putrid venison and living cheese say, in the charitably indirect language sanctioned by society, to a host who had gone to the trouble to provide the best he could think of, and had, amongst other things, thought of palm grubs, that such worms were food for pigs but not for human beings. And this is how we are governed throughont our lives in more important matters by the petty ideas imbibed in our youth in petty surroundings. But I am wandering away from the palm-grub, whose life history is more interesting 
than a dissertation on the prejudices of mankind. One of the most extraordinary faculties possessed by many insects is that power of locating and arriving at the object of their desires from very great distances. It is difficult for us to form any correct conception of such a power, considering how defective are our senses in this respect. The entomologist takes advantage of this instinct-the word instinct being applied to those attributes of animal life superior to our own qualification in some particular direction and consequently beyond our understanding-to capture the males of certain Bombyces, chiefly Kentish Glories and Emperor Moths. A virgin female, when ' calling,' that is, slightly convulsed with tremor, is placed in a small cage made of two little hoops tied crosswise and covered with gauze. This the entomologist carries about with him. If there be any males of the same species in his vicinity he is pretty certain to capture them, for they will crawl into his pocket should he have placed the caged female there. I have referred to this extraordinary faculty certain moths are endowed with, because the beetle ${ }^{1}$ which produces the palm-grub is also gifted in a similar fashion. No sooner is a palm-tree cut down than the beetles find it out and lay their eggs in the juicy pith which serves as food for their larvæ. Incisions are made in the trunk of the palm so as to expose the pith and thus facilitate the work of the beetle. At the end of about a fortnight the larvæ have been hatched and the grubs are fit for eating. They are removed and placed in vessels with water, where they will live for a couple of days. They are prepared by being fried or roasted on a skewer. Should the grubs be allowed to remain for three weeks in the palm-tree they assume the third stage, that of the

\footnotetext{
- Rynchophora palmarum.
} 
chrysalis. Perhaps there is no more remarkable instance of this attribute of certain insects of arriving at, in a manner incomprehensible to us, some object necessary for the perpetuation of their species or advantageous to their welfare, than the visits paid by a large bee to one of our commonest orchids (Catasetum tridentatum).' This bee, which Darwin describes as a Euglossa, is rarely seen except when the Catasetum is in bloom. But then, it does not matter where one of these plants may be, the bees are sure to find it out. They appear as if by magic in small swarms of five or six, or even ten individuals, as soon as the buds expand, and they will continue their visits, returning every morning to feast on the thick viscid stuff distilled by the flowers during the night. In their struggles to get at the nectar they are so passionately fond of, they disturb the highly sensitive pollinia, which fly out and attach themselves by a sticky disc to the heads of their voracious guests. Should the bee afterwards visit a female flower with his burden of pollinia he repays the hospitality he has enjoyed by assisting in the propagation of the Catasetum, whose flowers will at some future period furnish a delicacy for his descenlants, while ensuring the perpetuation of their species. The female Kentish Glory, with her mysterious power of attraction facilitating her impregnation; the palm-beetle, with its faculty of ascertaining when and where have fallen the trees whose decaying pith furnishes food for its larvæ; the perfect development of some particular sense enabling the Euglossa bee to find out and indulge in the luxury of which he is so fond; the marvellous relation-

1 In his Fertilisation of Orchids Darwin has so fully described the sexual forms of the flowers of this orchid that I think it needless to dilate on the subject here, although it is an exceedingly interesting one. 
ship existing between the bees and the Catasetum, a relationship on which the latter depends for the continuity of its species: these are but a few instances of the wondrous contrivances of Nature, the results of the gradual development and perfection of particular organs or senses useful to their possessors or necessary for the preservation of their kind. And yet, in spite of these evidences of the adaptability of life to almost any condition we may think of; in spite of the positive proofs we possess of the changes effected during the course of ages in the structure and habits of the beings inhabiting our globe, and of those who peopled it in the past and are no more, the majority of mankind persists in upholding that each form of life as we see it now was so created from the very beginning, with man, of course, at the head of the list. Why should we discard a theory so flattering to our overweening vanity?

But to return to our friends at La Prision, who certainly do not worry themselves very much as to how they appeared on earth, or whither is bound whatever immortality they may possess, their thoughts being too much occupied with the material question of obtaining food for the day. They add something to their bare diet of rice and peas and coarse ground provisions by hunting, but game is not over abundant in the immediate vicinity of the settlement. Now and again a tapir is killed. At rare intervals bands of peccaries visit the clearing, doing considerable damage before they are dispersed, with the loss of a few of their number whose flesh, salted and dried, is consumed by the owners of the ravaged gardens, not as inight be supposed in the spirit of retaliation inculcated by the principle of an eye for an eye and a tooth for a tooth, but because the flesh of the peccary is really excellent 


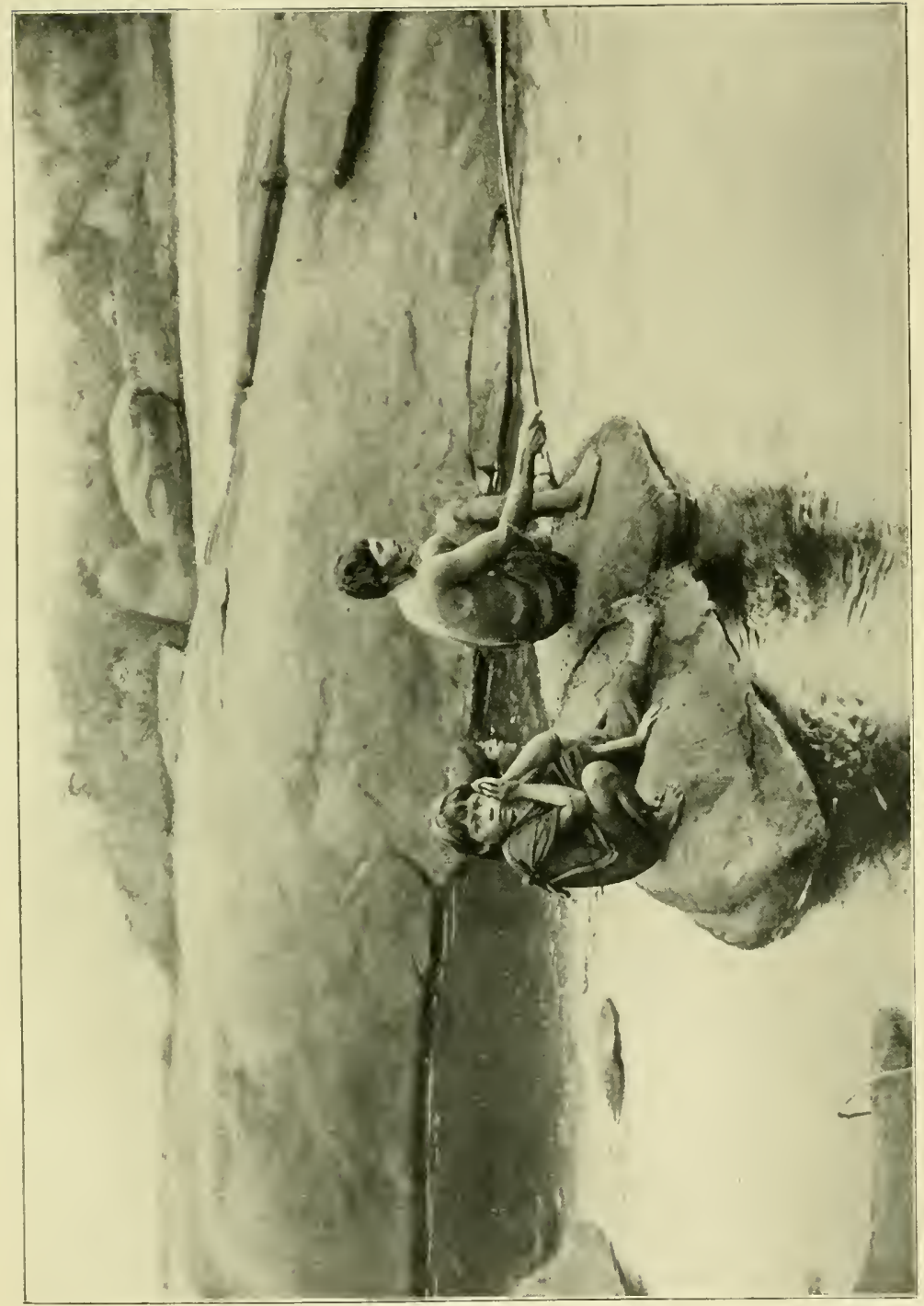

0
2
$\frac{1}{1}$
$\frac{0}{4}$
0
0
0
0
0
0
$\vdots$
0
5
3 

cating. Of all the inhabitants of La Prision I should say that there was only one man who was a born hunter, and he was the only one who owned a shot-gun and dogs. He was a powerful, middle-aged mulatto named Luis Urbana. To what breed his two dogs belonged remained a mystery which we never succeeded in solving. But whatever may have been their origin, he was proud of them, his conversation consisting exclusively of stories exhibiting the sagacity and courage of Meoro and Cazador, these being the names he had bestowed on the half-starved quadrupeds who accompanied him in his wanderings. $\mathrm{He}$ was also the only man I ever saw during my stay at the settlement fish with a hook and line in true sportsmanlike fashion; the fishing which the others engaged in being of a rather indirect character.

Sometimes during the creciente or rising of the Caura, shoals of fish ascend the creek on which is 'The Port,' as the people call the landing-place. No sooner does this welcome news reach the houses than there is a general rush for the stream, Medina, who always has dynamite cartridges ready for such a contingency, being usually the first to arrive at the 'The Port.' A cartridge is lighted and thrown into the water; then another and another. The ground vibrates with the explosions. The men rush to the boats, shouting and gesticulating. They paddle wildly about, catching the stunned fish by their tails as they come to the surface and throwing them into the boats or on shore; but, after all, they secure but a small portion of the victims. For days after dead fish may be seen floating on the waters, and the destruction of the smaller fry is simply appalling. Fishing with dynamite as practised at La Prision is exciting work, not devoid of danger, as some of us experienced on one 
occasion when a cartridge was thrown into the pool at 'The Port' and exploded before reaching the water. The man who threw the cartridge was hurled to the ground with violence; we, who were further off, were quite stunned by the concussion of the explosion and suffered from deafness for hours afterwards.

One of the most grotesque sights I ever witnessed occurred in connection with dynamite fishing at the mouth of the Caño Guayapo, ${ }^{1}$ where we spent a month in 1898 collecting birds. Our camp overlooked a deep pool in which a large electric eel had taken up his quarters. We saw a good deal of him as he floated lazily on the surface of the water enjoying himself, a habit to which he appeared to be addicted and which led to his meeting with a violent end. One of my men, who had from the very first regarded the eel's indolent happiness with an envious eye, amused himself in a moment when time hung particularly heavy on his hands by dropping a dynamite cartridge into his premises, with the object he explained of knocking the animal's electric battery out of him. The result of his experiment was as diverting as it was unforeseen, for the explosion of the dynamite roused an old alligator whose presence in the pool no one had suspected. For fully five minutes we were treated to the most extraordinary display of aquatic gymnastics it has been any man's lot to witness. One moment we saw the alligator's tail and the next his head, the entire performance of the huge reptile in his dazed state being of a most ludicrous nature. As clown he would have made the fortune of the manager of an animal circus. While

1 Caño Guayapo is some distance above Puerto Antonio Liccioni, on the left bank of the Caura. It is a stream which rises in the mountain range of Hilaria. 
the alligator was trying to find out what had occurred to him, the men ran for the rifles and wasted cartridges taking snapshots at the exposed parts of his body while he performed irresponsible somersaults. Eventually he regained sufficient consciousness to realise that the pool was no longer a haven of rest, and he headed for the stream at a rate that would have made a bicycle scorcher open his eyes.

In the course of my description of fishing with dynamite at La Prision, I referred to the creciente or sudden rise of the Caura. Anyone unaccustomed to the ways of streams in countries of heavy rains would be surprised at the increase which sometimes takes place in the volume of a river like the Caura in an exceedingly short space of time. Though we were well aware of the vagaries of the river we were exploring, we suffered repeatedly, either by leaving things where we thought the water could not possibly reach them, or by mooring our boats close to the banks. We would awake in the morning to find that some very necessary article had been carried away, or that a heavily laden boat was high and dry on land. There is a large slab of rock close to "The Port' at La Prision. We experienced a good deal of inconvenience whenever this slab was covered by the creciente, for we found it very useful in more ways than one. By using it as a mark we were always able to tell how much the river had risen or fallen in a given time. Here the women used to wash our clothes and procure our supply of drinking water, for the temperature of the stream is several degrees lower than that of the Caura, owing to its being completely shaded from the rays of the sun by the tall trees of the forest through which it flows. Here we spent the early morning and had our bath 
using big calabashes to pour the water over us. It is dangerous to get into the water in the Orinoco or any of its tributaries, on account of the fearlessness and voracity of some of the fish which inhabit these streams. Most of the men I had with me had been brought up either on the banks of the main river, or of one of its affluents. They were in consequence unable to swim. They told me that they did not stand in much fear of alligators, but that they dreaded electric eels and rays, and, most of all, the rapacious caribe. This terrible little fish has been most appropriately named after the ferocious aborigines of the Antilles, who have contributed the word cannibal to our language. I had one day a good opportunity of observing this characteristic of the caribes of immediately setting upon and devouring any members of a shoal the moment they appear to be disabled or unable to take care of themselves. I was washing out a pot containing paste into which some carbolic acid had been put to prevent its being attacked by cockroaches. The caribes, attracted to the spot by the white particles, greedily swallowed the bits of paste. Those who had succeeded in securing the biggest share of this dangerous food paid the penalty of their gluttony, for no sooner did an individual turn upon its side and show signs of distress than it was immediately attacked by the others and torn to shreds.

Jacobson took several views at La Prision, and at the rapids of Mura. After he had developed his plates. which he always did at night, the washing-boxes would be taken down to the slab of rock where we had our bath in the morning, and there we would spend an hour or two.

While the tedious process of cleansing was being performed I whiled the time away by spreading a piece 
of cotton under our lantern and catching moths. How often during those silent hours of the night have I not wandered into dreamland, while I lay gazing lazily at the stars above, with Jacobson like some alchemist performing strange antics over his plate-boxes in the dim lamplight! I would give myself up to musing upon my journey to the little known country beyond the falls of Para. What mountains were those of which the Indians spoke with such awe, where dwelt the spirits of mischief who forged the deafening thunder and awoke the raging storm? Why had the tribes on the lower reaches of the liver passed away in so short a period? Would we reach that distant village on the slopes of the Pacaraima mountains along whose base the infant Merevari threads its tortuous course? . . J Jacobson would break in upon my meditations with his strong German accent. 'I want somebody to help me with these plates - I can't carry them up to the house alone,' he would be saying, and I was back at La Prision, with Améha and Arawa and the Indian village far away in the uncertain distance. We would trudge wearily to the house, disturbing the nightjars who had been catching insects in the narrow path which leads to the rancheria, and I would retire to my hammock to dream again of Améha and Arawa and the distant village near the sources of the Merevari. 


\section{CHAPTER X}

FAUNA AND FLORA OF LA PRISION-THE CLEARING

Hornets - Butterflies - Nightjars - The wood-nightjar - Hawks - The

Guaco-Rice-birds - Ants and ant-thrushes-Man and the other animals-Utopia.

A NATURALIs' might spend weeks at La Prision adding daily to his collections without having to wander beyond the limits of the clearing. He will find out within a very short space of time after he will have taken up his quarters in Doña Antonia's house that there are at least two kinds of insects which were not created solely for man's pleasure and glorification. Until he will have learnt to move about with circumspection he will be sure to arouse the suspicions of the colonies of hornets who own the ceiling of the establishment, and he will not forget the circumstance for hours after. When I first visited La Prision I had with me as taxidermist a young creole who was a bit of a dandy and a great admirer of the fair sex. He was slinging his hammock with studied grace while two of Doña Antonia's daughters looked admiringly on, when he realised that something had gone wrong. No man looks a hero when he is boxing with a hornet. So the spell was broken. 'Was it nice?' the younger sister, who was a bit of a tease, inquired. ' Not as nice,' replied my fellow countryman with the ready wit of the creole, 'as a liss from a sweet girl like you'; and he scored in spite of the disfiguring marks left by the hornet's stinging caress. 
If the hornets pay attention to the person of the collector, the ants devote themselves to looking after his collections; so that, what with having to dodge a being with wings and a sting who means business when he has made his mind up, and trying to devise ways for keeping his property out of the way of an insect that can find a grain of sugar in a stack of hay, the amateur naturalist acquires his first real knowledge of the powers of those so-called lower forms of life.

The yards near the houses are usually in a filthy condition, owing to the number of domestic animals which are allowed to roam about the place. At La Prision the cows and calves were tied to a tree close to the kitchen during the night, so that they might not wander into the forest and get lost. The pigs had the run of the house, and as they belonged to the breed known in the States as razor-backs and had to forage for themselves, we were being perpetually reminded of their existence by the destruction of our boots, hats, and such unlikely articles of food; but nothing comes amiss to the razor-back. The united efforts of these quadrupeds, and of the turkeys, fowls, and ducks composing this domestic menagerie had imparted to the place a very pronounced smell suggestive of a pigsty and stable-yard combined. We did not find this smell agreeable, but it was otherwise with many gorgeous butterflies, for whom it appeared to be as myrrh and frankincense. Anyone acquainted with the habits of the Lepidoptera cannot have failed to observe how many kinds of butterflies will persist in returning to, and alighting on, some particular spot, although repeatedly disturbed. These butterflies are, at times, so engrossed by their attempts to secure places on the locality of their selection, which is usually of but small extent, that the whole batch, 
consisting of many hundreds, may easily be captured in an ordinary net. The yard around Doña Antonia's house at La Prision, reeking of animal effluvia, was a favourite resort of many of the butterflies of the district. As a matter of fact I secured more specimens at this place than anywhere else. On hot sunny mornings they began to assemble between eight and nine, increasing in number until midday, when they actually swarmed all over the place. By far the greater proportion was of the genus Callidryas with a fair number of red and black Heliconii. Although the different kinds would fight for the same spots, it appeared to me that in alighting each species tried to herd with its own kind, for the various sorts would be usually bunched together. Those separated from their congeners were sure to be late arrivals who were glad to secure a place anywhere. Of the other butterflies subject to this infatuation for alighting on some small spot of damp ground, apparently in no way different to hundreds of square feet around, I may mention Papilio protesilaus, Metamorpha dido, and Carois chorinæus. ${ }^{1}$ The last butterfly, however, appeared to prefer the parts of the house where we lived as resting-places. I was surprised at the number which came to the house, because, so far as my experience goes, these butterflies are not met with in numbers. At times they would remain stationary, either slowly opening and shutting their wings, or keeping them quite closed. At other times they shuffled along the posts, stopping at intervals for a few moments. I noticed that these posts were infested with wood-lice and very small ants. May not the presence of

1 The abundance of Carois chorinceus at La Prision may be accounted for by the existence of fields of sugar-eane, on which the larva of this species is said to feed. 


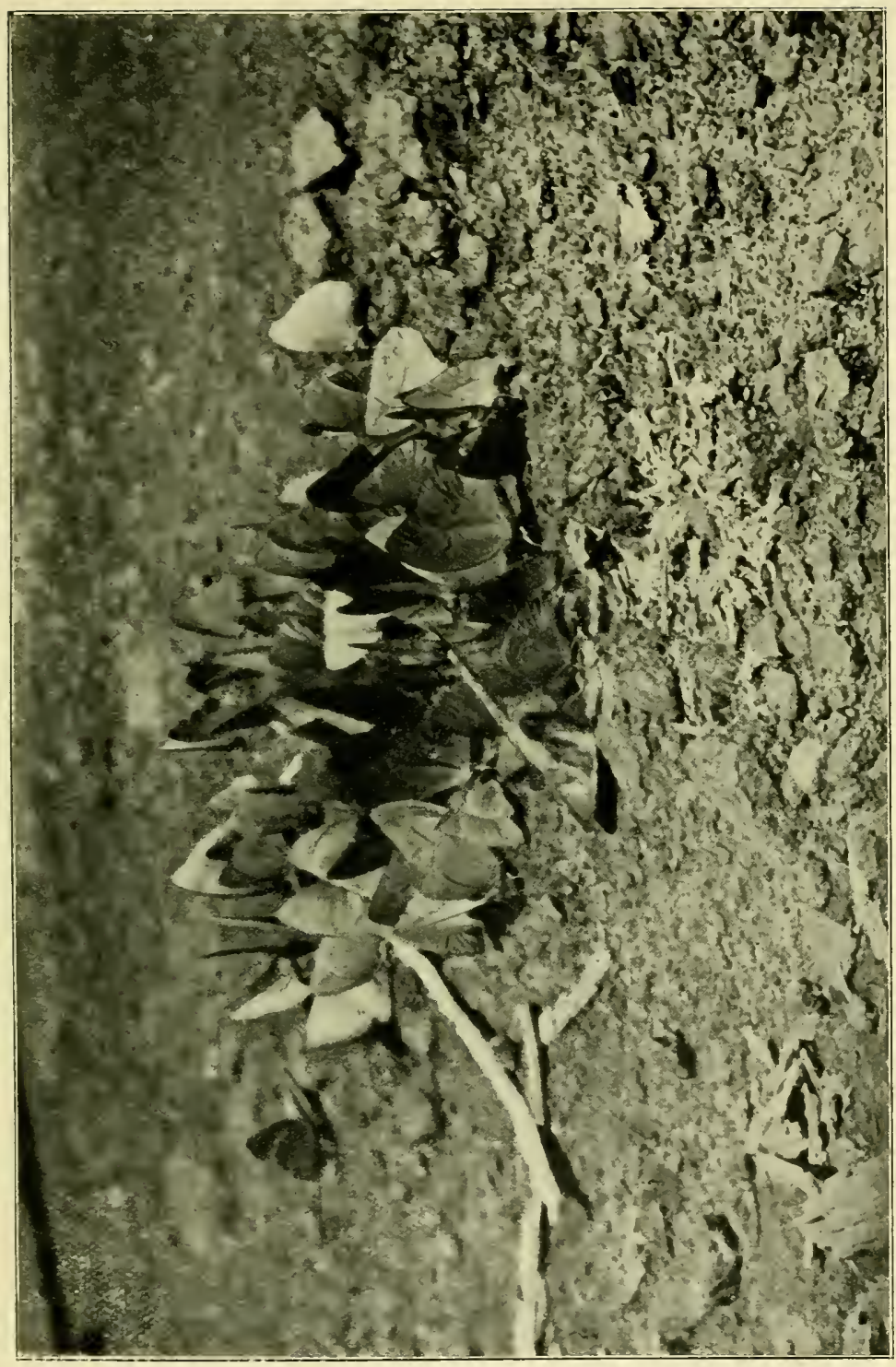

号
$\frac{1}{4}$
$\frac{\pi}{4}$
5
5
5 

these insects have something to do with the visits of the Carois to the house at La Prision?

These dirty yards surrounding the houses, frequented by butterflies during the day, were also the favourite hunting grounds after dark of nightjars, which are common on the Caura. They used to be particularly moisy on bright moonlight nights. Two of them had taken possession of the open space around the houses, and they would return night after night, one appropriating the part in front of our quarters, the other occupying the yard at the back of the kitchen. There they spent the night quite close to the houses, uttering at intervals their loud and discordant notes. With the approach of daylight they went away. The nightjar is called in Venezuela Aguaitacamino-the watchman of the roadson account of its habit of frequenting the paths after sunset. At Panama, where it is plentiful in the open savannas, the natives call it Bohio in imitation of its cry. These nightjars spend the hours between sunrise and sunset sitting close to the ground, generally in low scrub. On the Caura they are in the habit of passing the day upon the lajas and islands in the rapids. Squatted on the dark rock of which they seem to form part, it is most difficult to distinguish them. When disturbed they flit a short distance away and then drop suddenly on to some spot where they remain perfectly motionless, trusting to the strong resemblance they bear to their surroundings to escape detection. Closely allied to this smaller species, but very much rarer, is the large wood-nightjar. The plaintive wail (it can scarcely be called anything else) of this bird at dead of night would startle anyone unacquainted with its origin. The hunters and woodcutters of both Venezuela and Trinidad, with but very few excep- 
tions, persist in asserting that this wail is made by one of the sloths. In the island of Trinidad the cry of the wood-nightjar can be heard on almost any night in the stretch of mangrove swamp along the coast between the towns of Port of Spain and San Fernando. The woodcutters who pass a part of their lives in this waste of wood and mud, say that as the sloth toils lazily from branch to branch he utters at intervals the complaint 'Poor-me-one-O.' What has probably led to this error is the existence in the swamps of the little anteater in fairly large numbers. The woodcutters have in consequence associated this ant-eater, which they call a sloth, with the strange cry they hear at nights.

The wood-nightjar is a difficult bird to detect during the day. He chooses for perching some mottled stump or branch so closely resembling his plumage that he appears to form part of the bough upon which he is sitting. I suppose in my wanderings I must have passed quite close to a good many of these large nightjars, yet I must confess that only on one occasion did I get a good opportunity of observing the habits of this bird. We had had a morning's duck-shooting and were resting in the shade of one of the mangrove-trees which line the creeks, when what had appeared to me to be a dry stump jutting out of one of the branches seemed to move slightly. I threw lumps of clay and bits of stick at it, but it did not move until it was actually struck, when, to our surprise, a wood nightjar flitted a short distance away, alighting on a stump similar to the one which he had quitted a moment before. $\mathrm{He}$ immediately flattened his tail against his perch and assumed an attitude which gave him all the appearance of being part of the stump on which he rested. I disturbed him repeatedly and he invariably followed the 
same tactics. He always chose as resting-places stumps or branches which his plumage resembled, and he assumed an attitude so suggestive of a piece of wood that I would certainly have passed him by had I not been watching his movements and seen him alight.

Many other birds are seen quite close to the houses, or in the clearing around, which may be looked for in vain in the gloomy forest beyond. For there are many kinds of birds with socialistic principles who find life easier in the neighbourhood of man, where they can appropriate a share of the results of his labours, than in the wilderness where they would have to depend entirely on their own exertions. Of the smaller birds, whose biggest offence is petty larceny on a limited scale, the man who tills the soil and rears poultry does not speak with bitterness; but start him on chicken-hawks or the large rice-bird, and you will be able to add something to your swearing vocabulary. Though most members of the hawk family have a fondness for poultry, there is one species on the Caura, called the Guaco, that has earned for itself the unrelenting enmity of those who like to see the domestic fowl knocking about their premises. When I heard some of the anecdotes illustrating the cunning of this bird of prey when he has fixed upon a district where he intends to carry on a series of operations, I could not but compare his proceedings with those of a class of Trinidad vagabond who is cursed in a similar manner with an incorrigible weakness for the contents of other people's fowl-houses. For both culprits the punishment is severe. The biped without feathers gets six months and thirty-six lashes: the other is treated as heretics used to be in the good old days of the auto-da-fe. Doña Antonia told me that one Guaco had eaten dozens of her fowls before he was 
wounded and captured by one of the peons, who had been detailed specially for the purpose of taking him dead or alive. The owner of the fowls off which he had feasted, and her friends, had the grim satisfaction in this instance of hanging him over a slow fire while they sat cheerfully around enjoying his sufferings as he was slowly roasted to death. Such is the fate of the Guaco when he happens to be taken alive by the people on the Caura. Of all the places I have visited, Tucumay, about thirty miles south of the city of Panama, is the spot where I collected most hawks. Close to the hut where we lived, which was in an open savanna where a good many cattle were kept, a swamp several square miles in extent exists. The swamp is fringed with a belt of forest, which was the abode, when I stayed there, of large numbers of water-fowl. Many hawks of different kinds also inhabited this belt of wood. The country around consists of rolling plains covered with a short coarse grass. During the dry season this grass is set on fire, so that with the first rains the cattle may get the benefit of fresh green food. The natives told me that a reddish-brown hawk, of which I secured some specimens, was in the habit of taking advantage of these savanna fires for having a regular. feast. These hawlis, according to their statements, keep circling over the smoke just in front of the advancing fire, ready to pounce upon any lizards or serpents attempting to escape from the fiery death behind them. The natives have in consequence christened this bird Beber-humo"'The smoke-drinker.' May it not be that the birds also devour the half-roasted bodies of the lizards and snakes overtaken by these fires?

If the Guaco considers that he is entitled to levy a toll on the poultry yards, the rice-bird is convinced that 
he has a vested interest in the grain-fields. The first time I saw a flock of these birds negotiating a rice-patch I became a convert to their convictions. It was a pleasure to observe how they conducted their operations ; I say a pleasure, because I had no share in the rice-fields. At one end of the clearing there was a huge tree, still standing although dry and devoid of leaves. This was the coign of vantage the birds had fixed upon as a base for their operations, and they could not have made a wiser selection. In the mornings and afternoons, while the flock was feeding, only two or three individuals remained on the bare branches of the tree. They were the sentinels whose duty it was to notify their comrades below of any suspicious manœuvre on the part of those who had planted the rice. A note of alarm and the whole flock would leave the field like a well-drilled battalion. The birds would betake themselves to the tree, where they would remain if no attempt were made to follow them up. It was perfectly useless, as we found, to try to get within shooting distance of the tree. The birds invariably flew away and scattered about in the wood at the edge of the clearing. One of my hunters did bring in a couple of specimens of the rice-bird once: they must have been the idiots of the flock.

In my wanderings along the margin of the forest I frequently came across detachments of Parasol Ants (Ecodoma cephalotes) returning to their homes laden with booty obtained in the gardens. Like the moundbuilders who peopled North America in prehistoric times, these ants also build mounds, in which are their colonies, connected by subterranean galleries. If the ants with their burden of leaves be followed they vill be seen to enter holes in the mounds, out of which other ants having 
deposited their loads are issuing in search of fresh material for their gardens, for these little workers are agriculturists of a high type. The ants hurrying to and from the mounds are the foragers. Those who have made a close study of the habits of these ants say that each forager drops her portion of leaf in the nest, which is taken up as required by the small workers, and carried to a clear space in the nest to be cleaned. This is done with their mandibles, and if considered too large it is cut into smaller pieces. It is then taken in charge by the larger workers, who lick it with their tongues. Then comes the most important part, which almost always is done by the larger workers, who manipulate it between their mandibles, mostly standing on three legs. The portion of leaf is turned round and round between the mandibles, the ant using her palpi, tongue, her three legs, and her antennæ while doing so. It now becomes a small, almost black ball, varying in size from a mustard-seed to the finest dust-shot, according to the size of the piece of leaf that has been manipulated. The size of the piece of leaf is from one-eighth by one-eighth of an inch, to onequarter by one-quarter of an inch. It must not be understood that only one class of workers manipulate the leaf, for all seem to take to it very lindly on emergency. Even the smallest workers will bring, their tiny ball to where the fungus-bed is being prepared. These balls, really pulp, are built on to an edge of the fungus-bed by the larger workers, and are slightly smoothed down as the work proceeds. The new surface is then planted by the smaller workers with slips of the fungus brought from the older parts of the nest. Each plant is planted separately, and they know exactly how far apart the plants should be. It sometimes looks as if the plants had 
been put in too scantily in places, yet in about forty hours, if the humidity has been properly regulated, it is all evenly covered with a mantle, as of very fine snow. It is this fungus they eat, and with small portions of it the workers feed the larvæ.

The habits of another species of ant (Eciton) which may be observed in the vicinity of the clearing, present a striking contrast to those of the agriculturist Ecodoma cephalotes, although exhibiting a similarly high development in the direction of organisation. I could always tell by the sharp contented chirp of the ant-thrushes, ${ }^{1}$ whether the hunting ants were out foraging. Of these ant-thrushes, I think one of the most conspicuous is the white-crested Pithys albifrons, a bird common enough, but rarely seen except when the hunting ants happen to be abroad.

It is interesting to sit on some log close to the living stream of destruction as it hurries along and observe the doings of these hunting ants and of the birds who have learnt to take advantage of their foraging expeditions to procure food for themselves. No leaf is left unturned, no crevice unexplored, by these terrible hunters. For yards in advance of the invading army the ground is alive with crickets, moths, lizards-in fact, with every creature whose home is the rotting leaves and damp earth of the forest. Few living things escape. Those not overtaken by the ants fall a prey to the birds accompanying them. Now and again the army throws out battalions from the sides which hurry forward and meet ahead, enclosing a number of victims for whom there is no escape. All the time the ant-thrushes display great activity, flying rapidly down to the ground to return almost immediately and

\footnotetext{
1 Formicariidæ.
} 
alight on some low shrub whence they perform the same operation repeatedly. The movements of some of these thrushes are so quick that it is difficult to follow them. In the stomachs of those birds I shot I found fragments mostly of soft-bodied insects such as moths and crickets. In spite of the vast numbers of various kinds of insects destroyed by the combined efforts of the ants and birds, these tropical forests teem with an insect life which appears to suffer no diminution.

To the inquirer into the marvellous ways of Nature nothing can be more interesting than to compare the habits of various animals with those of the most highly developed of them all-man. The Guaco is the solitary hunter relying on himself alone, cunning and relentless, and with an insatiable thirst for slaughter. In the flocks of rice-birds who have learnt how to make use of sentries in order to guard against surprise while they are committing their depredations, we have an instance of an understanding such as exists between the members of small savage tribes for mutual protection. The densely peopled colonies of Parasol Ants, with their foragers and growers of food, are the counterparts of those civilised communities where each person follows some particular occupation with the view of obtaining greater skill in special branches than if the same individual had to undertake a variety of employments. Everyone who has read 'The Naturalist in Nicaragua' will remember Mr. Belt's exhaustive account of the habits of these and other ants of the tropics, in which he concludes as follows: 'When we see these intelligent insects dwelling together in orderly communities of many thousands of individuals, their social instincts developed to a high degree of perfection, making their marches with the regularity of 
disciplined troops, showing ingenuity in the crossing of difficult places, assisting each other in danger, defending their nests at the risk of their lives, communicating information rapidly to a great distance, making a regular division of work, the whole community taking charge of the rearing of the young, and all imbued with a strong sense of industry, each individual labouring not for itself alone but for all its fellows-we may imagine that Sir Thomas More's description of Utopia might have been applied with greater justice to such a community than to any human society. "But in Utopia, where every man has a right to everything, they do all know that if care is taken to keep the public stores full, no private man can want anything; for among them there is no unequal distribution, so that no man is poor or in any necessity, and though no man has anything yet they are all rich; for what can make a man so rich as to lead a secure and happy life, free from anxieties, neither apprehending want himself, nor vexed with the endless complaints of his wife. $\mathrm{He}$ is not afraid of the misery of his children, nor is he contriving how to raise a portion for his daughters, but is secure in this, that both he and his wife, his children and grandchildren, to as many generations as he can fancy, will all live both plentifully and happily.", 


\section{CHAPTER XI}

FAUNA AND FLORA OF LA PRISION-THE FOREST

Bejucales-Curassows, grullas-Tinamus-Habits of curassows-The kingtody and other flycatchers-Scarcity of snakes in the forest-The jaguar-Orchids-The lajas-The evenings at La Prision.

THE Caura runs along the southern side of the clearing at $\mathrm{La}$ Prision. On the north, east, and west the latter is bounded by forest. This forest, as I have already said, forms part of that vast stretch of woodland which includes within its limits the most interesting yet least known part of the tropics. The tonca-bean collectors have cut tracks from the settlement to the lajas, in whose vicinity they build their huts during crop time and where they dry the beans they may have collected. The most important of these tracks reaches a spot called Esperanza, and is, I should say, about fifteen miles in length. Here the tracks of the sarrapieros end, and this was the farthest point reached by anyone at the settlement until March 1898, when I cut a path to the mountain of Turagua. These tracks of the tonca-bean gatherers proved very useful to us in our collecting expeditions in the forest. I usually left the house at daybreak accompanied by one of my boys, who carried my twelve-bore breech-loader and a haversack with our midday meal and collecting implements. For killing birds there is no more convenient weapon than a muzzle-loader of small gauge. I only used my breech-loader for large birds of prey or for big 
tough game-birds like curassows and penelopes. On our way to the forest through the provision gardens we almost always succeeded in securing a few specimens. They would be mostly finches, tanagers, tyrant flycatchers, and those humming-birds found in the clearings or at the edge of the woods. Silently we would enter the gloomy stillness of the forest, for it was an understood thing that we were not to speak except in whispers. If we were separated we communicated with each other by imitating the call-notes of the small owl. ${ }^{1}$ This is the bird of illomen of the Trinidad negro, for is not the uncanny come, come, come of the bird of night the call of death? And did not the boding bird which haunts the ruined piles and hallowed urns round unhappy Turnus fly when he had his last stand-up fight with the pious hypocrite who is credited with having humbugged the queen of Carthage and founded the Roman Empire? The Trinidad birdbutcher who helps to supply the hat market with feathers is an adept at hooting like an owl. He knows that hummers and other small birds, with generations of grievances against the midnight murderer, will mob him in numbers during the day if they can find him out. So he sits under a tree and hoots in the dismal fashion that freezes the marrow in the bones of superstitious old women, and he puts a premature end to the life of many a feathered beauty attracted by the spirit of revenge to the hiding-place of the wily dealer in bird-skins.

With the exception of those belts or tracts of tangled creepers and bush called bejucales, the virgin forest, although possessing an undergrowth, is not difficult to get through. The bejucales are the dread of all those wanderers in the woods who make a living either by 
hunting or collecting forest products. Woe to the wretch who gets lost in one of these mazes of interminable creepers-creepers from the size of one's leg to the thinness of thread-running along the ground, climbing up over the tops of the tallest trees to return again striking their roots into the damp spongy soil, and with renewed vigour branching away in every direction, a regular spider's web for the poor devil lost in its interminable toils. The bejucales are the favourite haunts of tortoises and armadillos. Peccaries, also, are fond of visiting these cool damp resorts, where the ground is spongy and soft and they can dig as much as they please in search of the roots which constitute so large a part of their diet. Many of the larger game-birds are also in the habit of frequenting the bejucales. By scratching in the thick bed of rotten leaves covering the ground they obtain the worms and insects which form part of their food, while the trees with their dense overgrowth of creepers afford them good hiding-places. Some of these creepers are fruit-bearing. Of a kind of fruit about the size of a coffee berry, and yellow in colour, which hangs in clusters from a species of bejuco, both Paujis and Pavas are particularly fond. Pava is the native name of one of the penelopes, and it is as common as the Pauji in this region. But of all the larger birds none affects these densely wooded parts of the forest more than the Grulla, ${ }^{1}$ one of the Psophiida. There are few birds more striking in appearance than this trumpeter. It is generally met with in flocks, which at times consist of quite a large number of individuals. If a flock be disturbed while the birds are feeding close together on the ground, as is their habit, they usually make off in a body and go a considerable distance before

\section{Psophia crepilans.}


again alighting; but if they be scattered, each individual on being alarmed flies up to some branch of a tree near by, where it utters its call-note almost incessantly, so as not to be separated from the other members of the flock to which it belongs. A wild rush into the midst of the flock, if it be a large one, is the best way to scare and divide the birds, when they can be killed singly. In this manner it is possible to secure a good many of the birds before they unite and get away. The flesh of the Grulla is very tough, almost as tough as that of an old parrot; but this did not prevent the Indians from eating these birds whenever I killed any. The tinamus, of which there appear to be two or three varieties in this part of South America, are also in the habit of frequenting the bejucales. Although these birds are far from being rare, we obtained but few specimens. Living entirely on the ground, and at the least suspicion of danger hiding in the dense undergrowth, it is easy to understand why this bird is rarely seen. If surprised at close quarters the tinamu rises with a loud whirr, uttering a few quick notes of alarm. At times these birds rise from almost under one's feet, and they make so much noise that one cannot help being startled. A glimpse of a large dark bird as it disappears in the dense foliage is all that the hunter gets, and before he has had time to recover from his surprise the tinamu has vanished for ever. Although there is considerable difference in the size and markings of the members of this family, there is a great deal of similarity in their habits. Early in the morning and late in the afternoon the long-drawn plaintive notes of the tinamus can be heard. Towards sunset, on a gloomy rainy day, these birds appear to utter their call more frequently than at any other time. The flesh of all the tinamus is tender 
and delicate. In this respect no other South American birds can compare with them.

Two varieties of curassows which I have mentioned as frequenting the bejucales are met with in these forests. Both varieties are called without distinction Pauji; but when the natives wish to draw attention to the different kinds they speak of them as Culo blanco (Crax alector), and Culo colorado (Mitua tomentosa), on account of the difference in the colours of the feathers of the belly in each species. These two curassows appear to have similar habits. Both utter the same shrill note of alarm on being disturbed, and they make the same deep humming noise when calling to each other. I have never been able to notice any difference in the humming of the two kinds, although the native hunters pretend that they can tell one bird from the other by its call-note. But as it has happened on more than one occasion that a hunter, after declaring, upon hearing a bird calling, that he was going to kill a Culo blanco has brought back a Culo colorado, I have come to the conclusion that the natives cannot, as they pretend, always distinguish between the call-notes of the 'white' and 'brown' posteriors, as they have, with more reason than delicacy, elected to distinguish the two varieties. During the mating season, in the unfrequented parts of the forest, especially along the banks of the streams, the deep hum of the Pauji may be heard at almost any time of the day. But it is just before sunrise, and in the early hours of the morning, that the Pauji appears to be most disposed to hum. It is impossible to describe in writing the peculiar noise which these birds make. The native hunters imitate the Pauji by saying, 'El muerto esta aqui' - 'The corpse lies here.' It is while uttering in a deep tone this lugubrious chant 
that the Pauji usually meets its death, for the hunter can then easily track it to its retreat, when it falls a victim, as the people of the place say, to its own death-song. If the Pauji gets suspicious it immediately ceases humming, and that is an indication to the hunter that the bird has seen him or scents danger. In such a case the only thing for the sportsman to do is to remain perfectly still. The bird may get reassured after a while, when it again begins to call, and it can be then stealthily approached and killed. If wounded only, the Pauji usually succeeds in getting away. As these birds pass a part of their lives on the ground they are fleet of foot, and as they are moreover of muscular build and plucky disposition, if not killed outright, or very dangerously injured, they make good their escape in the dense undergrowth of the forest. The food of the Pauji is very varied in its character. It consists principally of the fruits and berries of the forest, of certain kinds of which the birds are passionately fond. Like the domestic fowl the Pauji is also much given to scratching among the decayed leaves on the ground in search of worms and insects. On more than one occasion I have seen these birds on the rocky islands in the rapids and on the banks of the rivers apparently feeding on the small snails which in certain places are fairly abundant. During the mating season the males are prone to be pugnacious and they engage in combats which sometimes result in the serious injury of one or both combatants. Isidor assured me that he had once come across two male Paujis engaged in one of these encounters. So engrossed were they with their fight that they paid no atttention to him, and he was able to observe them for some time. Eventually he secured both. They were so exhausted and injured that they made no attempt to escape when he 
put a stop to their duel. The same Indian told me that another but very much rarer Pauji inhabits the forest on the Caura, but as it is nocturnal in its habits, and retires during the day to some deep hole which it has burrowed in the ground, it is but rarely seen. No serious attempts appear to have been made to domesticate any of the curassows, although they take very easily to captivity and become quite tame. I have not heard of any case of their having been induced to breed in a state of domesticity. It is a great pity that persistent and intelligent efforts have not been carried on in this direction, as the addition of these handsome and valuable birds to the other regular denizens of the poultry yard would be most desirable.

Of the smaller birds frequenting the gloomy depths of the forest the most gorgeously coloured are the callistes, the trogons, the jacamars, and that rare bird the kingtody. ${ }^{1} \quad$ The bright scarlet or yellow breasts of the trogons appear to have been specially designed for attracting the flies and other insects on which these birds subsist. What is more likely than that an insect in search of food should mistake the patch of red adorning the collared trogon for the crimson flower of the rose of the forest, as the natives call the Brownea? And the brilliant crest of the kingtody may it not be a useful appendage rather than an article of dress? Trogons may be easily observed in tropical American forests, for they are far from being uncommon, but it is otherwise with the king-tody, which is, so far as my experience goes, an exceedingly rare bird. On two occasions I had the good fortune to see this beautiful fly-catcher in the haunts he affects. In both instances I met with him in the same surroundings though in localities a thousand miles apart. Shaded ravines 

where there are pools of water, would appear his favourite resort. Perched on a twig above one of these pools, the king-tody awaits his prey. He raises or depresses his brilliant crest according as he wishes it to be seen or is desirous of concealing himself; the rest of his body, although beautifully marked, being of a dusky hue, is difficult to distinguish in the gloom of his retreat.

At times, numbers of birds of different species will be seen together going from tree to tree, probably in pursuit of insects. On occasions like these it is possible to obtain in a short time more different kinds than are met with in a whole day's tramp. By sitting patiently on a log in the low scrub clothing the banks of the water-courses in the forest, one may obtain many a rare specimen. It was in such a spot that I saw for the first time, but failed to secure, a bird of a new genus, ${ }^{1}$ which Dr. Hartert has named after me. This occurred in November 1897. I had been seated for some little time in a patch of brushwood such as I have described, when there appeared on a twig so close to me that I dared not move or fire, the bird of which my boy Pedro succeeded in obtaining a specimen in February 1901, and which forms the type of the genus. Only he who has been a collector himself will understand how I felt when this strange bird, after looking at me in amazement for a few seconds, disappeared in the shelter of the scrub. I waited, it must have been for hours, on the chance of his returning, and for days I visited the spot, but without success. Singularly enough the specimen obtained three years after was killed in the very same patch of scrub by Pedro, to whom I had related the 1902.

1 Taeniotriccus Andrei, No. 132 of Novitates Zoologica, vol. ix., April 
incident when we were out shooting together in the locality.

There is a general impression among Europeans that tropical forests teem with venomous snakes. Although I have spent the greater part of the last ten years in the forests of Venezuela and Colombia, I am ashamed to confess that I am not the hero of any thrilling snake adventure. As a matter of fact I never give snakes a thought, and I will crawl through brushwood on hands and knees in search of any bird I may have killed with as little concern as if $I$ were in my own garden. But I respect wasps, hornets, and ants. I do not say that I have not met with and killed venomous snakes, but the danger of being bitten by them may be left out of account when we consider how rarely we hear of accidents from snake-bites in the region of the woods. In dry, arid, stony country covered with cacti and thorny bushes venomous snakes appear to be ever so much more plentiful than in the humid forests. Such a tract of country, for instance, as that on which the town of Cumana is situated, a place where it scarcely ever rains, appears admirably suited to certain forms of reptile life, including snakes. A gentleman who possesses a country seat a couple of miles distant from the town told me that some of his men, while clearing a piece of ground some two acres in extent, killed no fewer than seventeen rattlesuakes. All along the northern coast of Venezuela the rattlesnake is exceedingly common in the dry arid districts, but it is not met with in the virgin forest.

Of the mammalia of La Prision the most interesting are, of course, our blood-relations the monkeys. ${ }^{1}$

' Do not the results of Dr. Nutall's fascinating researches entitle monkeys to claim a blood-relationship with us? "The New Hiological Test 
The capuchins or ring-tailed monkeys, and the rociferous howlers, were the ones we met with most frequently during our rambles. On more than one occasion I observed capuchins perform an acrobatic feat in the style of the leaping somersaults from the springboard one sees at a circus. If a troop of these monkeys while travelling through the tree-tops came to a spot where the trees were some distance apart, they would run out to the end of some thin, pliable, but strong branch, and leap up and down until they caused it to sway violently: then, taking advantage of the momentum of the swinging branch they would clear the intervening distance one after the other, a feat they would have been unable to perform from a stationary object.

We never met with any of the larger carnivora in the vicinity of $\mathrm{La}$ Prision, although I learnt from the people of the place that they suffer from time to time from the depredations of jaguars. These animals are particularly destructive where there are pigs, donkeys, and dogs. The jaguar appears to have either a strong aversion for the dog or a great liking for his flesh.

In our daily excursions we were sure to visit one of the lajas. I always experienced a feeling of pleasure, or rather of relief, when, after having tramped for hours through the twilight of the forest, we would reach some open space gladdened by the brightness of the sun. These lajas and the rocky islands of the rapids appear to be excrescences of one immense substratum of granite of which they are the highest points. Where the rock is

for Blood in Relation to Zoological Classification.' By George H. F. Nutall, M.A., M.D., Ph.B., University Lecturer in Bacteriology and Preventive Medicine, Cambridge. Communicated by Sir M. Foster, K.C.B., Sec. R.S. Received November 2; read November 21, 1901. 
of smooth or rounded surface no vegetation exists, but wherever there are hollows in which a bit of mould has collected there is sure to be some sort of growth, and in proportion to the depth of this layer of vegetable matter is the Iuxuriance of the growth which covers it. The flora of these open masses of plutonic rock is so different to that of the surrounding country, that the traveller might well believe himself to be in another region thousands of miles away from the gloom of the forest with its huge trees, through which he had passed but a few minutes before. Several kinds of orchids are met with in such places. Some grow on the rocks alone, while others occur only on the moss-covered branches of the stunted trees, all knotted and gnarled peculiar to this vegetation. Cattleya superba and Epidendrum Stamfordianum, both of which are abundant in these places, attach themselves to trees and rocks. In the case of the former orchid, however, only a small number of plants are seen on the rocks, by far the greater proportion being found on the branches or trunks of trees. It is the opposite with Epidendrum Stamfordianum, which grows in such luxuriant profusion all over the rocks in certain parts of the lajas, that thousands of plants might be collected in the course of a single day. A very fine Oncidium and a large Catasetum also form part of this flora, but while the Catasetum is fairly abundant the Oncidium is rather rare. Epidendrum elongatum is another orchid which grows in large masses on the lajas, some of the masses being several square yards in extent. As this Epidendrum is very free in blooming, and its flowers vary in shade from light pink to the larkest scarlet, the effect produced by the brightness of colour against the sombre background of black granite is 
striking. I seldom saw any orchids in the forest itself, but wherever there happened to be open spots of granite or sandstone formation, orchids and flowering shrubs were plentiful. But it is not only in their flora that the lajas differ from the surrounding country. Their fauna is distinct. The birds we killed, the butterflies we caught, the lizards we saw, are peculiar to these places and are not met with in the forest. A species of jackrabbit is abundant on the lajas, but as they are nocturnal wanderers only, we never saw any. They spend the day in the clefts of the rock and under the layers which peel off from the blocks of granite scattered over the surface of the main mass.

It is close to the Laja de los Perros, ${ }^{1}$ which being the nearest to the settlement was the one most frequently visited by us, that there exists a huge slab of rock resting on two upright masses forming a natural shelter known to the tonca-bean collectors as La casa del viejo Guachee (the house of old Guachee). When collecting in $1898 \mathrm{I}$ used to stop before the old man's house and have a chat with him and his wife. The pair had departed and the house was tenantless, a heap of ashes where the woman had been in the habit of cooking being all they had left behind them.

The track which runs before old Guachee's house connects all the larger masses of open rock. After leaving the Laja de los Perros the first of these masses to be reached is the Laja Grande. ${ }^{2}$ Many ranchos are built in the vicinity of the laja during the tonca-bean crop, for its size and the flatness of its surface offer great convenience for the preparation of the beans. About a mile beyond in a north-easterly direction is the steep Laja

\footnotetext{
1 The Rock of the Dogs.
}

2 The Great Rock. 
Conchera,${ }^{1}$ which forms part of the hill of La Prision. Here there are two tracks, one leading over the crest of the hill, the other skirting it. Both of them meet at the most westerly of the lajas, Los Gallitos ("The Cocks-ofthe-Rock'), so called because once upon a time these beautiful birds fought, paired, and reared their young amongst the huge blocks of granite covered with orchids and flowering shrubs which adorn the black surface of the open mass. The blocks of granite are there still, but the cocks-of-the-rock have departed. Like the bell-birds, the presence of man appears distasteful to them, and if their domain be encroached upon by human beings they abandon it to retire to some distant recess where they can enjoy the solitude they love so well.

From Los Gallitos to the house at La Prision is a good stiff walk of a couple of hours, so that whenever we lingered until late in the afternoon in the vicinity of this laja engrossed in the work of collecting, we used to have to hurry up on our way home if we did not feel inclined to pass the night in the forest.

After dinner I would examine the specimens brought in by the other hunters, and this always gave me great pleasure, especially when I recognised some rare bird or butterfly, or saw for the first time some species unknown to me. With Jacobson's help I would put the butterflies in envelopes and label the birds for the taxidermist. Then, if we had no negatives to attend to and we happened to be too tired to speculate on the progress of the Boer war, or the results of the crisis in China, we would do a very sensible thing-go to sleep.

1 The Shell Rock. 


\section{CHAPTER XII}

EXPEDITION TO THE NICHARE, DECEMBER 22, 1900, TO JANUARY 28, 1901-FROM LA PRISION TO THE MOUTH OF THE NICHARE

Indians-Preparations for our departure-Departure from La Prision-Dugouts-Rapids of Mura-Water plants and tapirs-Burrowing birdsIndian settlement at Mura-Strange-looking trees-Christmas on the Caura-Facundo returns to La Prision-The Nichare.

WE spent several days at the settlement, during which, as I have said, we made excursions into the forest as far as the lajas, and to the Waiomgomo houses at Mura. We were forcibly detained by Facundo's illness. Since our departure from Puerto Antonio Liccioni he had been suffering from a severe irritation of the intestines, brought on by the quantity of freshly distilled rum he had consumed on the occasion of his parting from his friends. I decided to await his recovery before starting, because he was the most intelligent peon I had with me, and the only one, with the exception of the Indian woman from the Rio Negro, who thoroughly understood the collecting and preparation of rubber. I felt also that it would be an advantage to secure as many Indians as possible from the settlement at Mura. These men are indispensable as pilots in difficult parts of the river, but they are slow at deciding upon a journey, especially in the company of Venezuelans, for whom they entertain a strong feeling of dislike. To obtain the services of the men whom I 
required it was necessary to display the treasures I had brought in the shape of beads, gorgeously coloured cloths, knives, fish-hooks, and such other articles as appeal strongly to an Indian's fancy. With this end in view, about a week after our arrival I got three families from the Indian settlement to spend a day with us at $\mathrm{La}$ Prision. It was amusing to observe the excitement of the women, and even of the younger girls, when piece after piece of bright print was produced. The sight of so much finery so puzzled them that it was a long time before they could make up their minds. Finally I succeeded in securing the services of the three best pilots, or patrons, as they are called, of the Mura settlement, and they and their wives returned to their homes to await the day of our departure. When I compare the pleasurable excitement shown by these people at the sight of such articles as cloth and beads, with the behaviour of one of their number who had been to Trinidad with me after my first visit to the Caura, I cannot help thinking that that lack of surprise at seeing for the first time the greatest works of civilisation, which has been attributed by many writers to the Indians' aversion to show surprise, as being undignified, comes from an entirely different cause. In the case of Maite, the Indian who remained with me in Port of Spain, and whose emotions I had a great many opportunities of studying, I noticed that he expressed no wonder at seeing for the first time those things which one would have expected to have surprised him most. The steamers in the harbour, the locomotives on the wharf, were barely noticed; but when I took him to one of the large shops he expressed wonder and delight at the enormous quantity of cloth, beads, fish-hooks, and knives which he saw. In this instance he was able to 


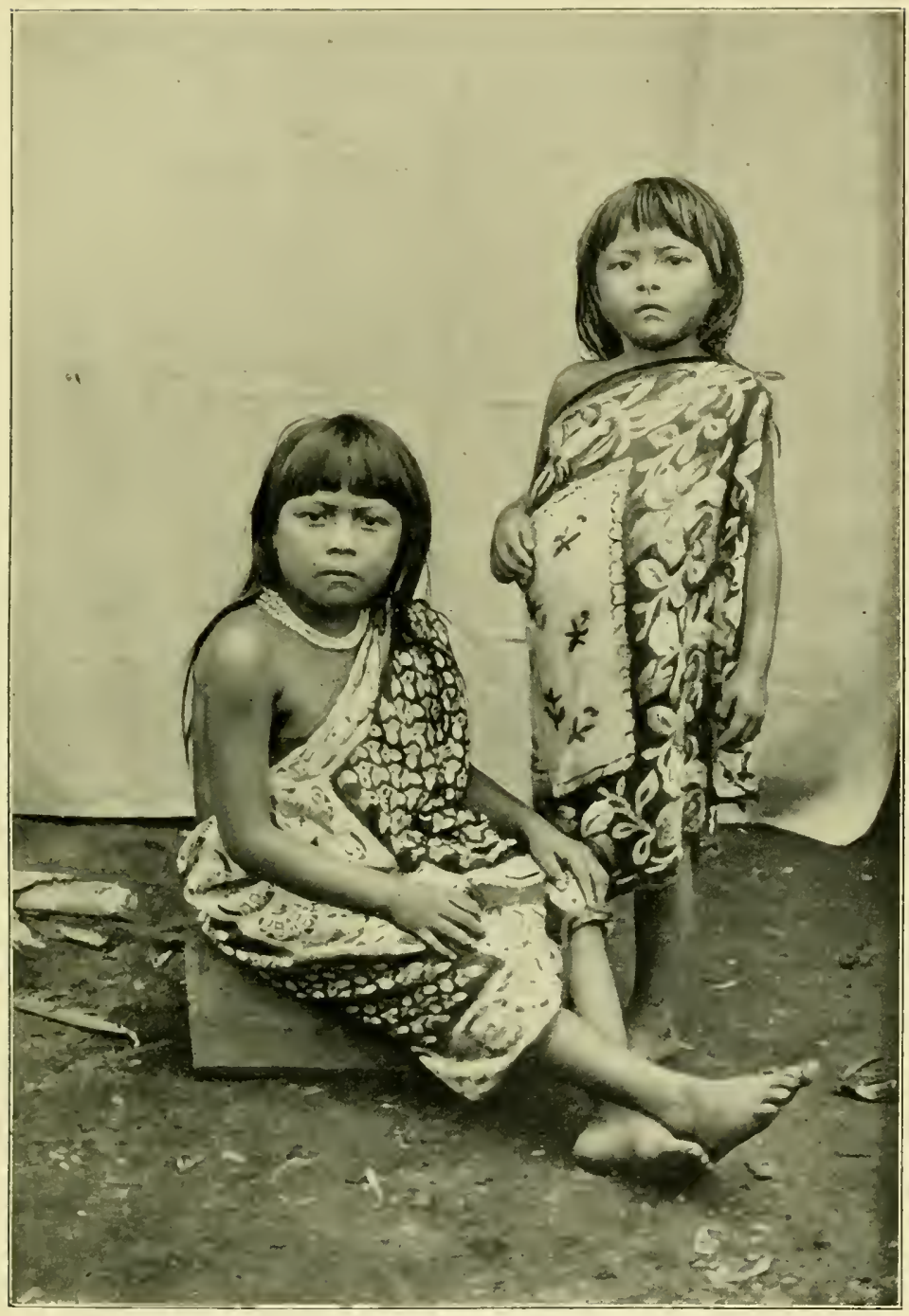

WAIOMGOMO CHILDREN 

institute comparisons and take an intelligent interest in articles of which he knew something. It was different with those more complex works so far beyond his simple experience.

When the Indians left for their settlement at Mura it was arranged that they should return on the 21st (December), the 22nd being the day we had fixed upon for our departure from La Prision. To have allowed the men to spend Christmas at the settlement would have entailed a delay of several days, perhaps of a couple of weeks, for the Christmas drunk of the peon, once started, is not to be interfered with. The Indians came on the morning of the 21st as they had promised, and we spent the whole day making up the provisions and our other things into packages of convenient sizes for loading the dug-outs. It was while this was being done that I realised to some extent the extraordinary aptitude for consuming food possessed by the men, who looked upon me as their purveyor for the time being, and for so long as I could supply them with all they wanted and their day's pay. The ten days spent at La Prision had been expensive ones. While we had been waiting for Facundo to get better, the men, finding that time hung heavily on their hands, whiled the hours away by cooking and eating. The Trinidad men and myself, who left the house early in the morning on our collecting excursions to return only late in the afternoon, had had no opportunities of observing the proceedings of the Venezuelan contingent. 'The eye of the master fatteneth the horse.' In the absence of the master the servant fatteneth himself, was the improvement my men had made on the old proverb; and if there were any who had not succeeded in gaining flesh at La Prision it was not through lack of trying. 
When we were ready to load the boats we found that it would be impossible to do so in the stream where we had left them on our arrival, as the month had been a very dry one and there was but little water at the landingplace. In addition to the three dug-outs we had brought with us, I had purchased a large one on my arrival at La Prision, and Medina had lent me his small curiara. They were all taken out to the Caura itself, and there the tedious operation of loading was performed. At ten o'clock on the morning of the 22 nd we were ready to start. We shook hands with the people of the settlement who had come to the river to see us off, and then we took our places in the boats, this being a matter that had been discussed and definitely arranged beforehand. The expedition consisted of twenty persons in all, nineteen men and one woman. The introduction of this apple of discorl into the elements of the expedition was an experiment of my partner in the rubber venture of the Nichare. 'This woman,' he told me when I left Ciudad-Bolivar, ' is the one thing you want to make the rubber business a success. She was born and bred in rubber surroundings. Besides,' he added, 'she can cook and wash clothes. I have written to my agent at Puerto Antonio Liccioni about her. She will be ready to accompany you when you get there.' And this was how the expedition came to possess a female expert in rubber. Her Spanish name was Juana, and she was supposed to be the goods and chattels of one Pio, whom she had brought with her. Having presented the lady I will introduce the gentlemen, who might be specified as belonging to three categories: those without clothes, those with the remains of clothes, and those with clothes of a sort. WVe, that is Longacre, Jacobson, the taxidermist, the men from Trinidad, and 
myself, belonged to the last division. The Indians, Isidor, Maite, and Vicente, were in the first. The Venezuelan contingent was the borderland of these extremes. Its constituents affected a compromise in rags, and this assisted in toning down to a certain extent the strong contrast between the Indians and ourselves. This general introduction will, I trust, serve to convey some sort of idea of the living material of which the expedition was composed.

The pilots of the large boats were the three Indians, Isidor, Maite, and Vicente. Luis Urbana, whom we had christened 'the Pirate' on account of his villainous expression and the old red handkerchief he was in the habit of tying around his head, was in charge of the medium-sized boat. Pancho Montenegro and the Indian woman from the Rio Negro managed Medina's small curiara, which carried the cooking utensils, and the bananas, yams, and sweet potatoes for the journey. All the traffic on the tributaries of the Orinoco, and on the upper reaches of the main stream, which do not allow of steam communication, or where the trade is too insignificant for the employment of steamers, is conducted by dug-outs. These dug-outs are of all sizes, from the small narrow canoe barely twelve feet long, that requires an education like that of a rope dancer before one can venture to travel with anything like safety in it, to the lumbering bongo of several tons burden, which will carry a whole family with comfort. All over Venezuela these dug-outs are called curiaras; the larger ones are known as bongos. Some of the largest dug-outs I have seen are used at Buenaventura on the Pacific coast of Colombia. The shipping and loading of passengers and cargo to and from the steamers calling at this port are done almost 
entirely by these large dug-outs hollowed out of the titans of the forest which clothes the banks of the Dagua. On the Caura the trees mostly employed in the construction of dug-outs are cedar and sassafras. On account of its lightness and its not being attacked by insects, cedar is the best of all woods for this purpose. Very large dugouts are worked with sails and oars; smaller ones with paddles. In the navigation of rapids and narrow channels only paddles can be used. The post of honour for a paddler is at the stern. Next in importance is the man at the bow, whose duty it is to look out for rocks and sunken logs, and while advising the pilot of danger ahead assist in avoiding it. The man at the bow is the proel, the pilot is the patron. Whenever we left any spot where we had stopped, if even only for a short while, the proel would call out, Vamos con Dios, patron, ${ }^{1}$ to which the pilot would answer, Vamos con la Virgen. ${ }^{2}$ Judging by our experiences during the journey, I have come to the conclusion that my men were not in the good graces of the Powers to whom these appeals were addressed.

On the day of our departure from La Prision we made but little progress. It was ten o'clock when we started, and $I$ expected to be able to reach the head of the rapids of Mura by sunset, but the boats having been badly loaded, and the men distributed without judgment, so that the best paddlers were all in one boat and the worst in the others, I decided, after we had gone about a mile, to stop and put matters right. For this purpose the boats were moored alongside a large slab of granite at the foot of the channel by which the guides had determined, after consulting each other, to ascend the rapids. They said

\footnotetext{
1 'May God be with us, cockswain.'

2 'May the Virgin be with us.'
} 


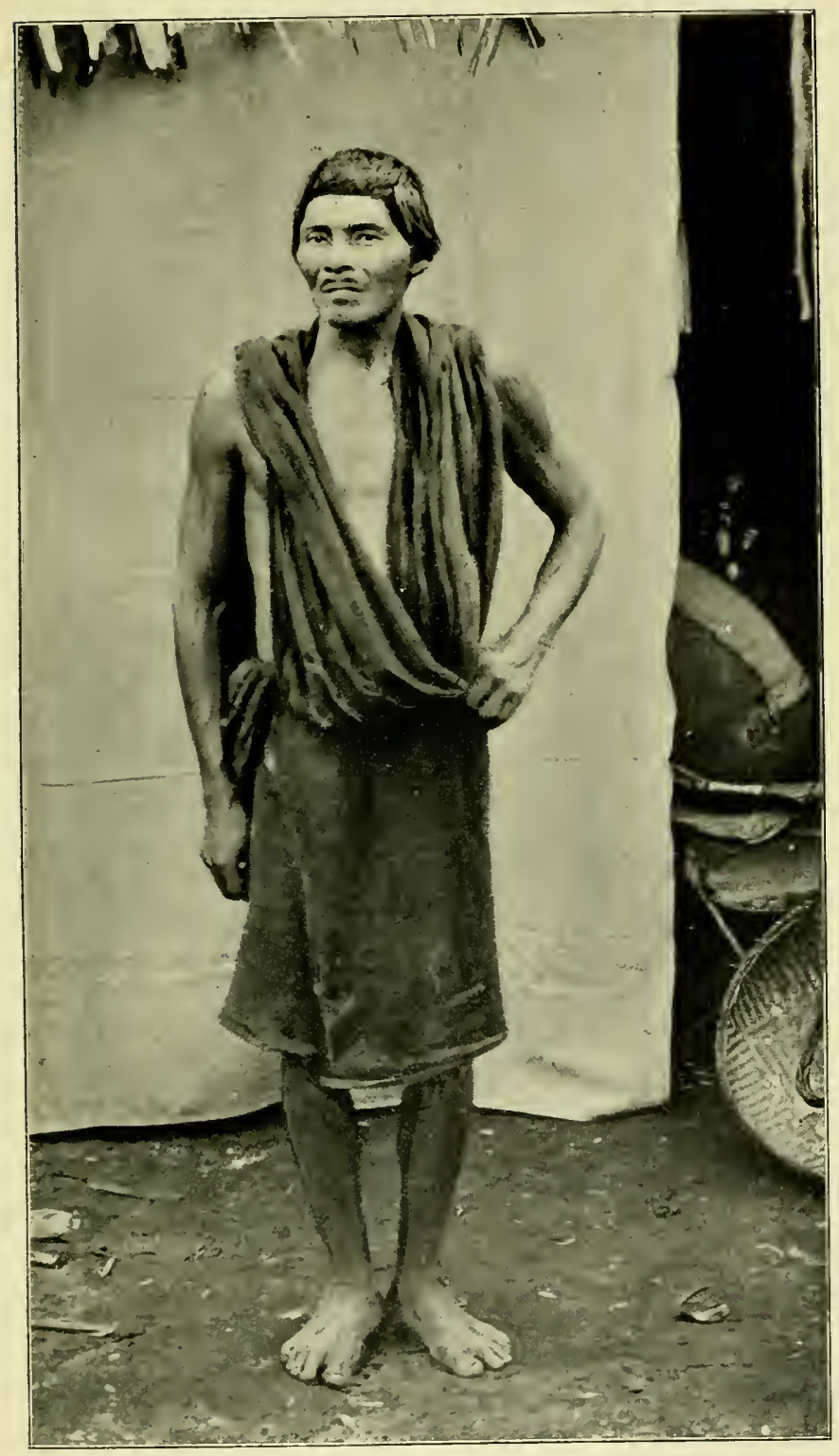



that the other passage, called Cinco mil pesos, ${ }^{1}$ although very much shorter, was too dangerous. Quite close to the spot where we landed is the site of an abandoned settlement, probably the collection of houses mentioned by Humboldt under the name of Ciudad de San Carlos. There were many cocoa-trees in the second forest growth which has sprung up where the old settlement stood, showing that the families who had taken up their abode at this spot cultivated the land to some extent, and had intended making a permanent stay, for the cocoa-tree does not yield any return for several years. The people of La Prision and Temblador are in the habit of coming in their dug-outs to pick the crop of these trees, the beans of which they grind between stones into a coarse kind of chocolate. We often drank this chocolate when our own cocoa gave out. While the boats were being reloaded some of the men had been wandering about over the site of the old settlement. They found a broken apothecary's mortar, and an old silver coin stamped 'Cundinamarca.' These I have kept as mementoes of the first attempt to found a town on the picturesque but turbulent passage of Mura.

Crossing the rapids in heavily laden boats such as ours is risky work. A moment's carelessness or hesitation on the part of any of the men may cause disaster; the breaking of a rope, if the boats are being hauled up where the current is too strong for paddling, may have equally dire results. In ascending rapids long strong ropes are of the greatest use. In fact, without them it would be impossible in certain places to make any progress. By one o'clock we were in the middle of Mura

1 'The passage of five thousand pesos,' so called on account of the loss of a boat at that spot during a tonca-bean crop, with a large sum on board. 
opposite to the Indian settlement on the left bank. The roar of the water rushing between the masses of coalblack rock, joined to the shouting of the men, tended to make the scene an exciting one. Several times we landed on the islands and walked along the banks while the boats were being towed up. Some of these islands are simply masses of bare rock, others resemble the lajas of the forest and are covered with a similar vegetation. Fields of a kind of wild pineapple occurred on many of the islands. On this occasion the pineapples were green, but during my first visit I tasted ripe fruit once or twice; they were so sour that I could never eat more than a small piece at a time. The blocks of rock and stunted trees are in places quite covered with festoons of the vanilla-vine. I never saw this orchid in such abundance anywhere else. Anyone living in the vicinity of the rapids who would take the trouble to fertilise the flowers of the vanilla and prepare the pods, would, I am certain, be able to obtain hundreds of pounds of this valuable product during the year. I explained this to Medina on my return to La Prision, but although he appeared interested in all that I told him concerning the vanilla, I do not expect that he or anyone else at the settlement will take up the systematic working of the wealth of vanilla at the rapids of Mura and on the lajas of the forest.

The river had fallen a good deal within the lașt few days, so that many rocks that had been under water for months were exposed. Some of these rocks were covered with an aquatic plant which Isidor told me is much eaten by tapirs. This plant (Neolacis corymbosa) was particularly abundant in places where the current was strongest. At first sight this neolacis, so soft and delicate, appears out of place, growing as it does, exposed to the full force 
of rushing water, in places where a man can barely stand if he attempt to wade up to his knees. But if the plant be closely examined it will be seen that while the stems and leaves are soft and pliable and yield to the force of the current, the roots are hard and wiry and cling with such tenacity to the surface of the rocks that it is almost impossible to remove the entire plant. Any attempt to do so resulted, as I found, in the breaking of the stem at the point where it springs from the roots. This neolacis exists only under water. With the falling of the river the exposed plants die, leaving a network of white threadlike roots with sharp points where the stems had dried up. If tapirs feed largely on these aquatic plants, as the Indians affirm, their elongated snouts would be of great use in tearing off the succulent leaves and stems from the uneven surface of the rocks to which the plants attach themselves.

Some of the slabs of granite upon which we landed were quite honeycombed with pot-holes. In many of these pot-holes there were either single stones or a number of pebbles, while others were half full of sand sometimes mixed with fresh-water shells.

Although it was quite early when we reached the Indian settlement at Mura, the men asked me to camp for the night. We chose a spit of sand along the bank not far from the settlement. The men planted poles, either in triangles or quadrangles, between which they slung their hammocks. 'The Pirate' said he preferred to sleep wrapped up in his blanket on the sand, so he made no preparations for passing the night, but went with the Indians to their settlement. Pancho Montenegro, the cook, and his assistant, Freddy, had made a big wood-fire, and the large iron pot full of vegetables 
and salted meat for the sancocho ${ }^{1}$ was soon simmering above it, with a batch of hungry men hanging around chaffing each other or cracking coarse jokes to while the time away. I wandered along the bank with my fidus Achates, Pedro Hospedales, the best hunter and birdcollector I have ever employed. In places where the sloping bank was of soft sand there were holes resembling those made by the land-crab, but these holes were not the work of crabs, but of a species of flycatcher with a short tail, not uncommon on the islands in the rapids. I made Pedro dig along one of the tunnels with his hunting-knife, but although he followed it for more than three feet he did not reach the bottom. I would have liked to have seen what sort of nest the birds make at the end of the tunnels. The Indians, although well aware of this habit of these birds of burrowing into the ground for the purpose of nesting, could not say whether the holes were used only once or repeatedly. I am inclined to believe, judging by the labour the excavation of these deep tunnels must entail, that they are used more than once by the same birds. This strange habit of excavating deep tunnels in the ground at the end of which they build their nests and lay their eggs is shared by the jacamars, kingfishers, and motmots. Parrots act in a somewhat similar manner, for although they do not dig burrows in the ground for nesting purposes, they always lay their eggs in the hollows of trees. The unsightly vulture, ${ }^{2}$ protected by law in Trinidad because it is supposed to assist in scavenging the town of Port of Spain, also builds its nest in hollow trees like the parrot, and for this purpose it usually selects some tree in the forest far from the town.

' The national dish, a soup made of vegetables with ment or fish. In the northern mountain range and along the const where beef is scarce or cxpensive the sancocho is usually made of fish. In the llanos beef is used.

= Catharles atrata. 
It was getting dark when Pedro and myself returned from our ramble. Dinner had been served out to the men, and they were sitting in groups over their large tin platters discussing the merits of Pancho's cooking. At this time of the year camping in the open air on the banks of the rivers is quite pleasant. Rain falls but rarely, and even then the showers are of short duration. It is quite different during the rainy season, when scarcely a day passes without its raining in torrents. After dinner some of the men went with me to Isidor's house, where besides Isidor, his wife, and children, we found Maite, Vicente, and ' the Pirate.' They were drinking yaraque ${ }^{1}$ and relating hunting-stories.

Of course the conversation turned upon tigers, and for the twentieth time my Indian companions treated us to a long series of stories illustrating the cunning and audacity of the tiger, as the jaguar is called by these people. I believe Isidor used to tell these stories with the view of terrifying my Trinidad men, and I cannot help admitting that his efforts were crowned with success, as none of them appeared to relish the idea of an encounter with the king of the American carnivora. After we had had our fill of tiger-stories we bade our Indian hosts good-night and returned to our camping-place on the sandy shore, lighted on our way by one of the men carrying a torch.

I was awakened long before daybreak by the noise made by the men who, squatted around the fire, were telling stories or chaffing each other while Pancho was preparing coffee. Most of my followers appeared to be very early risers, but I do not believe that they merited much praise for this seemingly extraordinary display of energy, the true reason of their leaving their hammocks in the early

\footnotetext{
' A fermented drink made from cassara.
} 
hours of the morning to hang around the kitchen fire being that they felt cold or hungry. With the first streaks of light the Indians joined us and we started, as we all wished to get through the trying channels of the upper reaches of Mura in the cool of the morning. We had to land repeatedly while the boats were being hauled against the powerful current, and I was able to study the vegetation we were passing by. I noticed that most of the trees on the islands, and along the banks where they are rocky, present a peculiar appearance. Imagine a trunk of the girth of a large forest-tree crowned by a few insignificant branches out of all proportion to the rest of the tree. These trees looked every bit as ridiculous as human dwarfs. In many instances the trunks were quite hollow, and they were moss-covered and full of knots. The conditions under which they had had to struggle for an existence had no doubt contributed to these peculiarities in their growth.

By noon we passed through the last channel of the rapids of Mura. Facundo, who had been complaining the whole morning of a severe pain in the intestines, begged me to allow him to have an hour's rest in the shade. He appeared to be very ill. The previous day's exposure to the burning rays of the sun had redoubled the inflammation from which he had been suffering. I was anxious to send him back in the small boat which could have rejoined us afterwards on the Nichare, but he insisted upon accompanying me for at least a couple of days. Between the rapids of Mura and those of Piritu there is no serious obstruction to the navigation of the river, which for a good part of the way is divided into two channels by a long island named Isla Larga. We stopped at three o'clock at an abandoned clearing of some toncabean collectors, who visit this spot regularly during the 


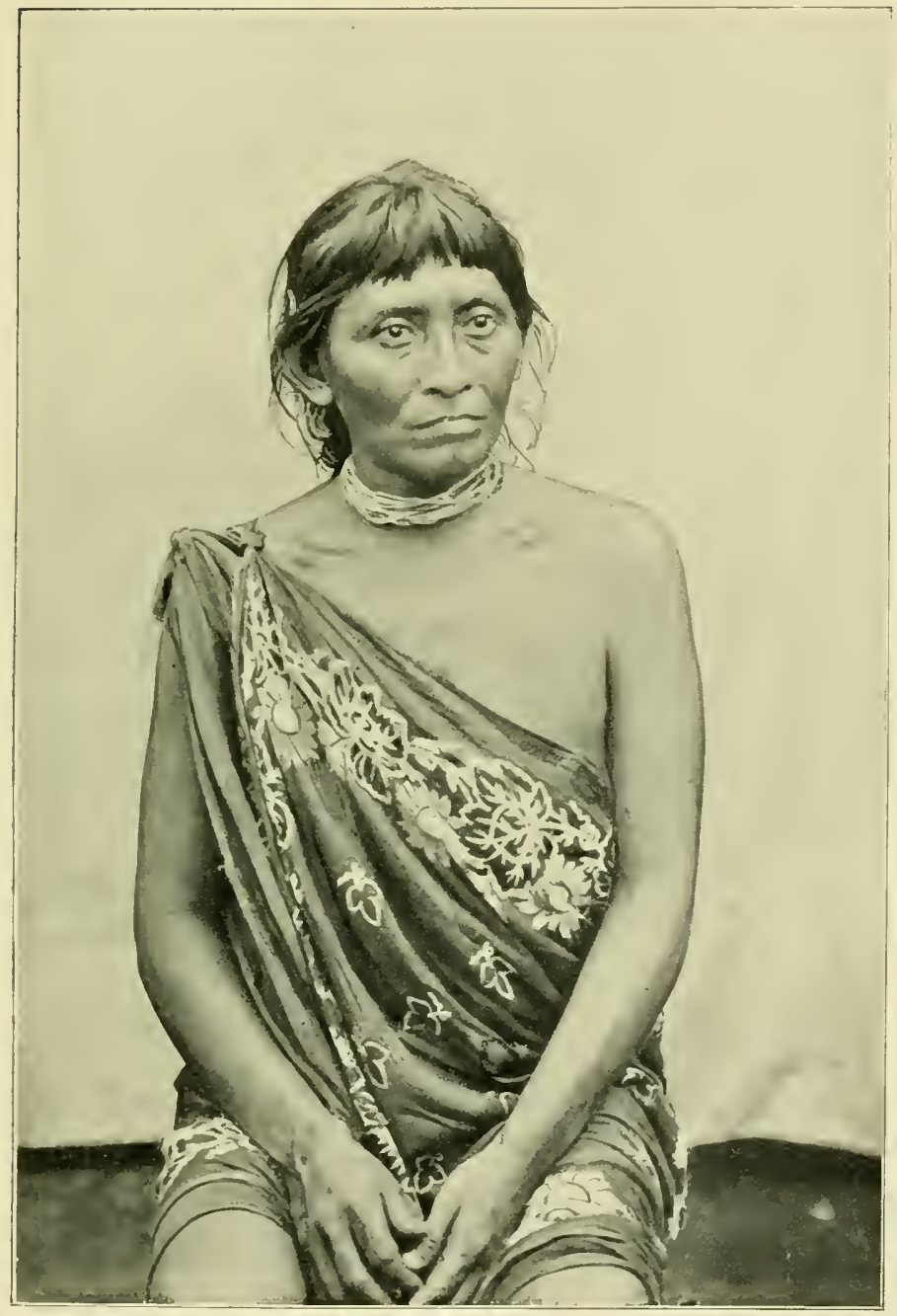

VICENTE'S WIFE 

crop every two or three years. The frail huts they had built were tumbling to pieces, and a rank growth of bush had sprung up where they had cut the forest trees down. A large tree that had been stripped of its bark stood as a sentinel in the middle of the clearing. Many parrots were on its bare branches when we arrived, and towards sunset two hawlis perched close together on its very top, evidently with the intention of passing the night, but Pedro disturbed their calculations by killing both with a single shot from my twelve-bore. These birds were smaller than the large dark-coloured hawk I have already described as being the terror of the poultry yards.

We spent Christmas afternoon on an island opposite to the hill of Cangrejo, the farthest point visited by toncabean collectors. Maite caught a large catfish, and as a Christmas dinner the men had roasted fish in addition to their sancocho. The only delicacy we were able to allow ourselves in honour of the day was a tin of lippered herrings brought by Longacre. Jacobson took a photograph of our camping-place in commemoration of the occasion.

All night long Facundo, who had been so unwell during the day that he was unable to stand, complained of acute pain in the intestines. He appeared so ill when day broke that I decided to send him back without delay. The small dug-out having been hastily unloaded of its cargo of provisions, a thick bed of palm-branches was made in its bottom. Upon this the men spread his blanket and then placed him gently on top. Two of my best paddlers, Benito and Pio, went with him, with instructions not to stop until they reached La Prision. After leaving him there they were to return with a fresh load of provisions and meet us on the Nichare. I bade 
Facundo good-bye just as the boat was being pushed off, and they were soon carried out of sight aided by the swiftness of the current. It was a last good-bye, for the poor fellow died a few days after, as I learnt when the men returned. Even when he left us I could see that his life was ebbing fast away, and as the little boat which bore him hurried down the stream I felt that his journey lay towards the river of oblivion.

It was late when we left Cangrejo, Facundo's departure having delayed us. Between this spot and the mouth of the Nichare, the river, although rapid in places, does not present such difficulties as at Mura and Piritu. Curassows and penelopes were more plentiful than lower down, and several were shot. Longacre killed two water snakes, measuring nearly eleven feet each. These water snakes appear to be common enough on the Caura and its tributaries, and some of them, according to the stories of both Indians and Venezuelans, grow to an enormous size. There is a widespread belief among the inhabitants of Venezuela and Colombia that there are snakes forty feet long and as big as a barrel, and that these huge reptiles can crush and swallow an ox.

At nine o'clock on the morning of the 27th we reached the mouth of the Nichare. On the right bank of the Caura, opposite to the spot where the Nichare joins it, masses of rock piled up in heaps, with large slabs between, adjoin the shore, which is steep and densely wooded. During the rainy months these rocks are under water, but they were at the time of our visit fully exposed. The boats were soon discharged of their cargo, as it was my intention to leave everything not absolutely required for the Nichare expedition at this spot, to be takien on our 


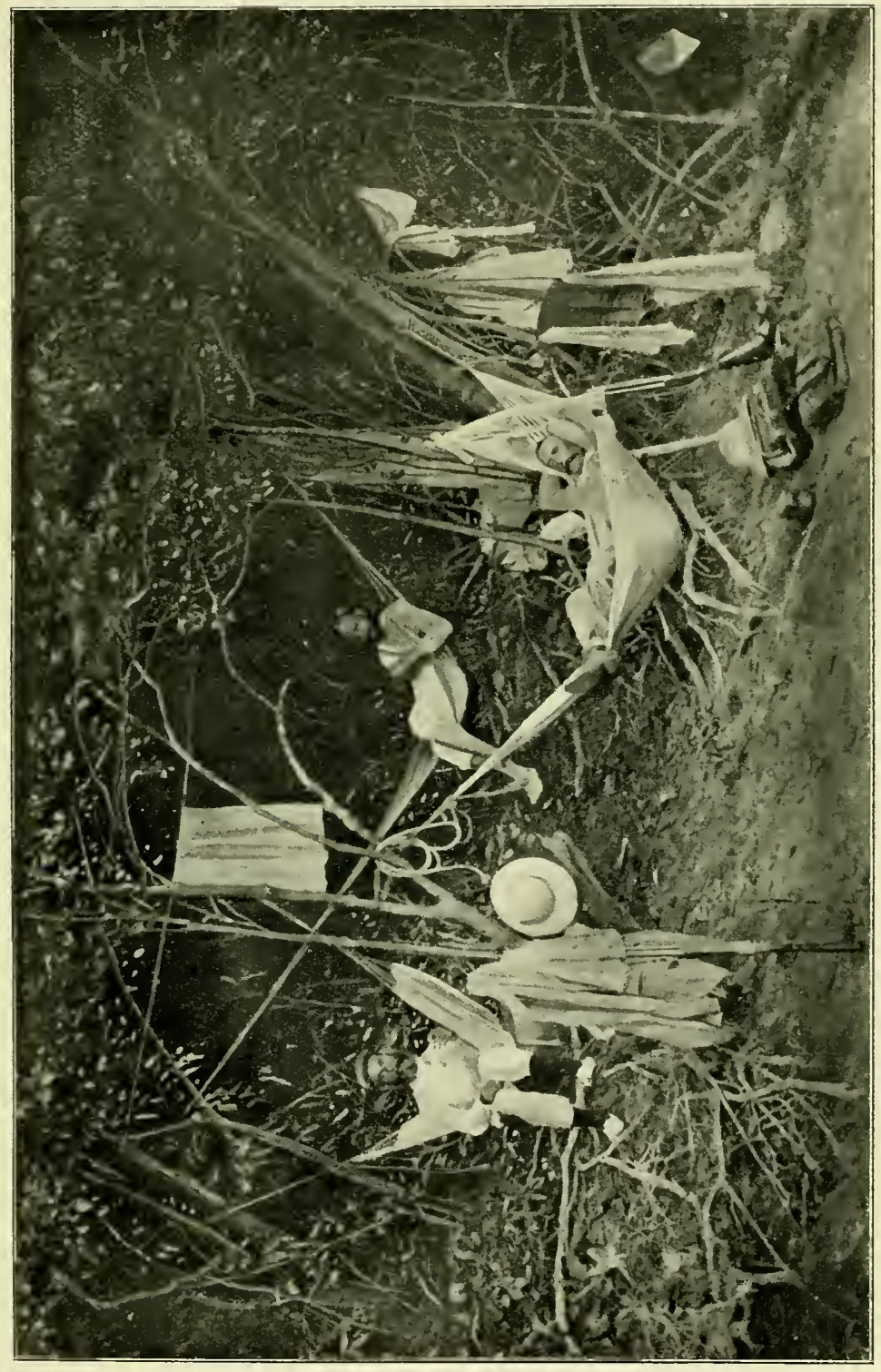

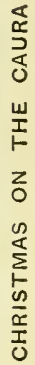



return. The men spent the rest of the day building a hat on the bluff above. In this hut the provisions and other articles destined for the journey above the falls of Para were stored. The boats were then loaded with the things we meant to take with us, and our departure fixed for the following day. 


\section{CHAPTER XIII}

EXPEDITION TO THE NICHARE, DECEMBER 22, 1900 JANUARY 28, 1901. THE NICHARE

My first tapir-Morocotos-Otters-The rubber industry-The rubber on the Nichare-Establishment of settlements-New birds obtainedNews of Facundo's death-Return to La Prision.

THE Nichare is wide at its mouth, but beyond the rapids of La Raya it narrows to a breadth of about 150 yards. I did not notice any appreciable diminution in its volume at Pozo Bravo, the farthest point reached, so that the river must be navigable for a considerable distance beyond.

My boat, with Isidor as pilot, was the first to reach La Raya. The ascent of this rapid is arduous and risky. The number of rays which infest the Nichare, and which appear to be particularly abundant at this spot, make the navigation of the river doubly difficult; for the men, being afraid to get into the water at critical moments when it is necessary that the boats should be pushed off any shallow spot where they may have grounded, lose so much time in jumping overboard that the boat is generally swamped before it can be floated. These rays, so dreaded by both Venezuelans and Indians, belong to the family of the sting-rays whose tails are armed with spines secreting a poisonous mucus. Maite described most graphically to twe how he was once wounded by a sting-ray, and how 
for weeks after he was confined to his hammock unable to move. From the caution he displayed whenever he had to get into the water where sting-rays might be expected, he must really have suffered severely.

We landed on some rocks on our right just below the rapids, where tufts of stunted trees grow from between the rubble forming the banks at this spot. The men having got on shore were preparing the ropes for hauling the boats up stream, when Isidor, who was in front, crouched close to the ground, and, pointing ahead, whispered loud enough for me to hear, 'Don André, Danta.' I Not 100 yards away, under a clump of small trees, was a large tapir. He did not seem to have noticed us, for he moved slowly out into the open, biting off leaves here and there from the small bushes as he strolled along. I had an old Winchester rifle I had picked up as a bargain, and a very bad bargain it turned out to be, for the rifling had been destroyed by its having been used as a shot-gun. With this wretched weapon I fired four shots at the tapir, who continued to graze without paying any attention to the loud reports of the shots. Throwing down the rifle I took my twelve-bore, and, creeping stealthily to within a few yards of my victim, I let him have both barrels. He fell on his haunches and I put an end to his sufferings by firing at close quarters into one of his ears. This was my first tapir, and one is generally proud of his first kill of any particular wild animal, but the slaying of this miserable-looking beast was not a feat to boast of. He was wretchedly thin, and his hindquarters, deeply scored, showed that he had but recently escaped from the claws of a jaguar. The wounds had not healed and were full of worms. He had escaped from

1 'Don André, a tapir. 
one beast of prey only to fall a victim to the most destructive of all animals. We left the carcase where it was and returned to the boat.

During the ascent of the Raya one of the boats filled with water, wetting the cargo, and rendering many of the articles useless. The river was actually swarming with fish. As our boat had got through first, Isidor, while we were awaiting the arrival of the others, exhibited his skill in fish-spearing. Considering the rapidity of the current his performance was a marvel of dexterity. The fishes caught were all Morocotos and some of them were of quite a respectable size. The Morocoto is one of the most esteemed of fresh-water fish on the Orinoco and its tributaries. It is not so plentiful on the lower reaches of the Caura, where much fishing has been done, but above the Indian settlement at Mura it is abundant. When certain forest-trees are in fruit the Indians catch many Morocotos with rod and line. The tackle used is of the most primitive description, but it gives excellent results. A strong green rod cut from some sapling on the river's edge, about ten feet of coarse line, and a large hook-that is all. A piece of fresh meat or bird-flesh serves as bait. This fishing is done by two men, one at the bow who casts the line, and one at the stern who paddles and steers. The boat is allowed to drift with the current, the paddle being used as a rule only for steering. Deep pools close to the bank, especially where there are overhanging branches of the copaiba-tree in fruit, are the best spots for casting. The bait is thrown with a splash in front of the boat, and this is repeated every few seconds until a fish is hooked. The Morocoto is a powerful and plucky fish, and would afford capital sport with a regular rod and reel. What more exciting sport could any 
adventurous angler desire than fishing for Morocotos from a small dug-out in dangerous rapids?

After leaving the rapids of La Raya we saw a good many otters. Some were basking on the rocks, others were swimming about. These animals are excellent divers; whenever they saw the boats coming they would raise their heads above the water and snort loudly, but they did not allow us to get close before diving. In any case it would have been useless to shoot them in the water, for their bodies sink and cannot be recovered. Isidor told me that they destroy large quantities of fish ; in this they resemble the other members of the familv found in different parts of the world.

We stopped early, and the things which had got wet at La Raya were spread out to dry. The bag of salt was quite saturated. This was serious, as salt happened to be very scarce when we left La Prision, and I had to be content with a quantity barely sufficient to meet the requirements of the trip. At night I had a strong attack of fever preceded by rigor and accompanied by violent headache, pains in every bone and muscle, and difficulty in breathing. I knew from the symptoms that I had contracted the dreaded malarial fever of the Caura which had very nearly squared all my terrestrial accounts in 1898.

At ten o'clock on the morning of December 31 we reached Pozo Bravo, our destination. An island occupies the middle of the stream, and there we pitched our camp. The small hut built by Richard on our first trip, when he explored the Nichare whilst I was at La Prision, was still standing, although in a somewhat dilapidated and leaky condition. The men repaired it and used it as a storehouse for our effects; it served in addition as an hospital 
for me during the twenty-one days we remained on the island. As I was far too unwell to look after anything, Longacre took my place and superintended the work of exploration of that part of the rubber region on the Nichare discovered and opened up by Richard in 1897 and 1898. The object of our expedition was, in the first place, to find out whether the rubber-producing trees existed in sufficient numbers to warrant the investment of capital in their exploitation; in the second, to ascertain what quality of rubber they produced and in what quantity.

In our experiments the system employed for obtaining the latex or milk is the one in vogue amongst the seringueiros of the Amazon. The seringueiros, or caucheros as they are called, usually work in families or parties of several individuals. Their first care when they discover some locality possessing within its radius a sufficient number of trees to render a remunerative return, is to cut tracks from tree to tree, so that each tree may be visited daily without difficulty. They then clear away the creepers and undergrowth surrounding the trunks of the trees, after which they clean the bark thoroughly by rubbing it with leaves. Everything is now ready for the process of tapping. This is done by torchlight before daybreak or with the first streaks of dawn, for it is at this time that the flow of latex is most abundant. The seringueiro goes from tree to tree armed with a tiny hatchet and carrying on his back a basket full of small tin cups with a tack-like protuberance on one side which is flat. He makes several incisions with his little hatchet in the bark of the tree, and he pins a cup under each so that the escaping sap may rum into it. A novice at tapping obtains but a poor result. The old hand, on the 


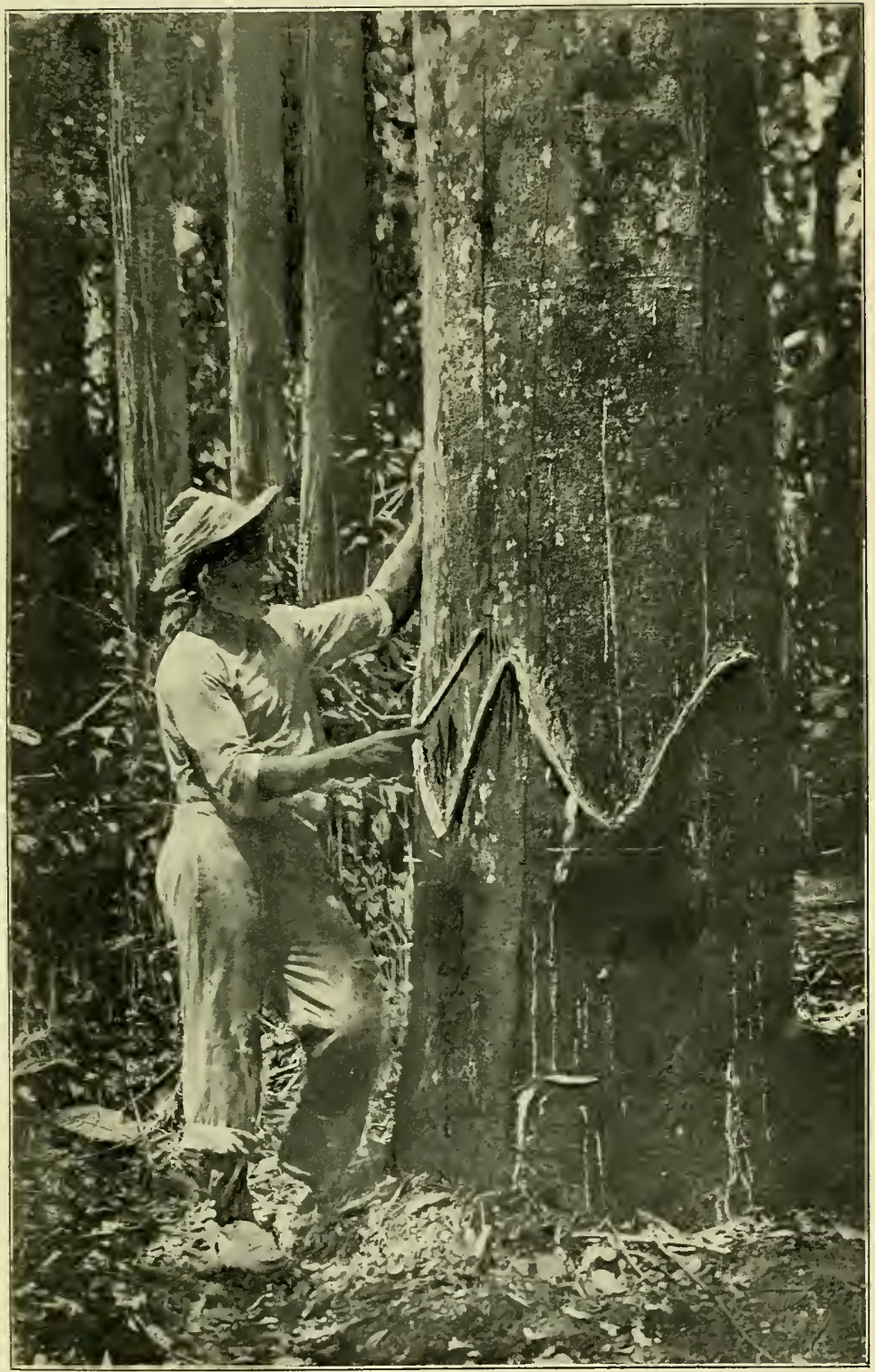



contrary, who can tell from long experience where the arteries run, makes his incisions only in such places as yield an abundant flow. It was chiefly for the purpose of instructing the men in this branch of rubber collecting that my partner had given us the benefit of the female expert's company. But her lord and inaster, who had resented the attentions paid her by the cook and others on the way, objected strongly to her serving as schoolmistress to her admirers in the solitude of the forest; so that she was more like a firebrand in a village of thatched huts than the peaceful lamp of learning my partner had intended her to be. And that is why I spoke of her, when referring to the composition of our party, as the apple of discord; not an apple of the choicest variety it is true, but good enough in the wilderness where there were no other apples, to cause dissensions which gave me a great deal of trouble and hampered our experiments.

The seringueiro having treated his batch of trees in the manner described, returns to the hut where he and the rest of the party eat and rest until nine or ten o'clock, when they revisit the trees, remove the cups, pour their contents into larger vessels, and then replace them under the incisions, taking care to keep the latter clean and open by removing any coagulated milk that may obstruct the flow of fresh latex. There remains to be performed the operation of smoking the milk, so as to produce the ordinary raw rubber of commerce known when it comes from the Amazon region as Para rubber. Certain nuts, especially the seeds of a kind of palm, are preferred for smoking, but where such nuts are not obtainable branches and twigs are used. The seringueiro, having prepared his fire, dips a paddle-shaped piece of wood into his vessel of latex, so that a thin coat of the milk adheres to the blade 
of the wood, which he holds over the smoke for a few moments, turning it round and round in order to expose every part of the surface to the action of the smoke. When he considers the first coat to have been smoked sufficiently, he again dips the paddle into the raw milk, obtaining a second coat, which he treats in the same manner. The operation is repeated until a mass of rubber of the size desired is obtained. This is removed from the paddle-shaped instrument by cutting it open with a sharp knife, and in this form it is exported after having been dried gradually by being hung up in the shade, under the branches of trees.

I have described in detail the process employed by the Brazilian collectors for obtaining and preparing their rubber, because it was the one adopted by us in our experiments. There is a cruder system where the tin cups, or, to give them their name, the tigelinhas, are replaced by a belt of bark, fastened tightly around the tree in an inclined direction. Wherever there are interstices in the belt they are filled with clay. The incisions are made above the belt so that the milk is barred in its downward progress, and running along the incline, falls into a calabash or some other receptacle placed to receive it. This system of obtaining the latex, although easier than working with tigelinhas, suffers from certain disadvantages. A strong shower of rain will wash away the clay after the belts have been prepared, in which case the whole work has to be done over again. The waste is ever so much greater, and the milk in its course along the trunk of the tree and the belt picks up many impurities that detract from the value of the rubber. Moreover, the belts, if not re noved, cut through the bark, stop the circulation of sap, and eventually kill the tree. 
While I was Iaid up Longacre made excursions in different directions, so as to determine whether the rubber-producing trees existed in abundance in the locality. He also carried on a regular system of tapping, obtaining samples of rubber and herbarium specimens of the tree producing it. I gathered from him on our return to La Prision, for I was too ill to think of or discuss any subject while we were on the Nichare, that the rubber-trees exist in numbers, especially in the low-lying lands, which would appear to be partially flooded at certain seasons of the year, but that the yield of milk per tree was disappointing. What surprised both of us was, that although in his experiments he had obtained as I have said but a poor result, yet he daily met with proofs that the trees must at times produce ever so much more latex than when he carried on his operations. Large flakes of coagulated milk were observed where accidental injuries had happened to some of the trees. In the Amazon region it does not pay to tap the trees except at a certain season; it is probable that the same conditions exist on the Nichare, but it is unlikely that the seasons coincide. That is a matter to be settled, so far as the Nichare is concerned, by a series of experiments extending over the greater part of the year. Regarding the tree producing the rubber Dr. L. Britton says :

'Referring to the samples of rubber gum, and the accompanying specimens of the foliage and flowers of the tree which you described to me as producing them, I would say that I am informed by Dr. John K. Small, Curator of the Herbarium of Columbia University, that the tree is a species of the genus Micrandra, natural family, Euphorbiaceæ, closely related to the genus 
Hevea. It appears from Dr. Small's studies that the species come nearest to Micrandra siphonioids of Brazil, but that it is probably different, and most liliely is an undescribed species. All the Micrandras hitherto linown are Brazilian.'

With respect to the rubber itself the following report was sent us :-

'Report on Three Samples of Orinoco Rubber, by John Murphy, Supt. Gutta Percha And Rubber Mfg. Co., Factory, Brooklyn, New York.

- This rubber is of good quality and clean, and if properly cured would class very nearly with medium Para. At present I consider it fully equal to good coarse Para.

"The rubber vulcanises readily and well; I find no material difference between the samples as to quality, but there is a difference in regard to shrinkage, as follows :-

- Sample A lost 17 per cent.

$$
\begin{array}{lllll}
, & \text { C }, & 21 &
\end{array}
$$

Sample A represents the pressed thin sheets.

" B $\quad, \quad$, wet clean umpressed sheet or
ball.
" C $\quad, \quad$, scrappy ball.'

I have entered into all these details here because rubber is to-day required for so many important industries that the discovery of fresh sourees of supply camnot fail to interest a large number of people. Unfortunately, under existing circumstances $I$ do not believe that the successful exploitation of the forests on the Nichare 
would be possible. How can any enterprise be expected to give satisfactory results in a country which might well be called the Land of Strife, where, during the last five years, there have been no fewer than three serious revolutions resulting in changes of government, without taking into account risings of a less important nature? Let us assume that a change would come over the spirit of this restless race, and that most of the men would make up their minds to work, leaving the question of government in the hands of a few-and this is a bold assumption-then the profitable development of the country's resources would become possible. But even then it would be some time before a forest product, even so valuable a one as rubber, situated in a region devoid of population and difficult of access, could be made to pay.

The first step towards the successful working of the rubber on the Nichare would be the establishment of a settlement or settlements like La Prision and Temblador, which are practically self-supporting, on the banks of the river. Expeditions such as ours, where every necessary has to be carried over a great distance, are far too costly to give profitable results. Considering that it takes ten days to reach Pozo Bravo from La Prision and two to return, some idea can be formed of the expense incurred where a large number of men have to be paid and fed for utterly unremunerative work. Besides, the men after days of paddling against the strong current, and the still harder work of hauling the boats through the rapids, are tired and disheartened when they reach their destination. But the greatest of all the benefits to be obtained by the establishment of settlements such as La Prision and Temblador in an uninhabited and unexplored region, 
is that the settlers wander about in their leisure moments, undertake hunting excursions into the forest, open tracks in all directions, and explore the rivers and creeks, so that with time they come to know the country thoroughly and are able to move about with confidence and rapidity, which is not the case with those taking part in casual expeditions. I am convinced that at some future period the rubber industry on the Nichare, and in other hitherto unexplored parts of the basin of the Caura, will form an important source of revenue to whomsoever may then possess that part of Venezuela.

While Longacre and his gang attended to the commercial part of our expedition, the Trinidad men were employed collecting birds and butterflies, but they suffered so much from fever that, although they did their best, we did not obtain the results I expected. Jacobson attended to the labelling of the specimens; Villegente prepared the skins. My men collected some good Callistes, among which were two males and one female of the beautiful Calliste paradisea. They also obtained the new Microcerculus caurensis ${ }^{1}$ and Ramphastos haematorhynchus, ${ }^{2}$ and a king-tody.

On the 6th the Indians, Isidor and Vicente, left us withont warning. They must have sneaked out of camp at dead of night, for no one was aware of their departure until it was discovered that the small boat was missing and that they had disappeared. I was very ill on that day and on the three or four following ones, so ill, as I learnt from Jacobson afterwards, that he and Longacre had fixed upon a nice cool spot at the foot of a large tree as a suitable resting-place for my fever-stricken remains.

1 No. 12 of Novitates Zoologica, vol. ix., April 1902.

2 Ibid., No. 338. 


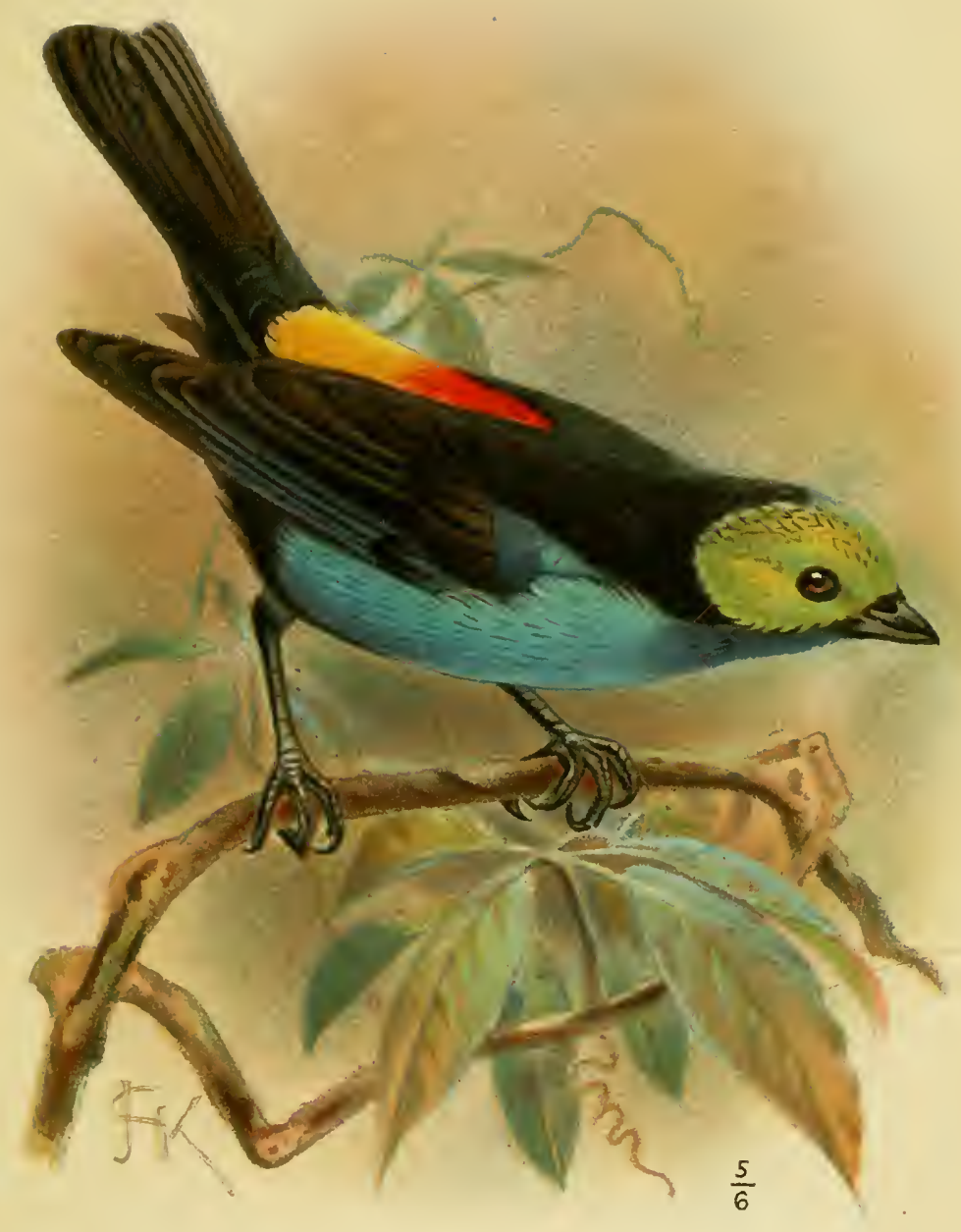

CALLISTE PARADISEA 

I have no doubt that my illness was the cause of the Indians abandoning us, for these people have a horror of being in the presence of death. Strangely enough, Maite did not accompany them, but remained with us.

The men who had gone with Facundo to La Prision returned on the 17th (January). Isidor and Vicente came with them, having decided, I suppose, that I was either dead and buried or convalescent; so that in either case they had nothing to fear. Their arrival was the cause of a good deal of commotion in our camp, as they reached Pozo Bravo late at night, long after the men had retired to rest, and they bore down upon the island shouting and yelling in true warlike fashion. The men, awakened from their slumbers in this unceremonious manner, believed that we were being attacked by all the Taparitos on the Nichare, and they rushed about looking for their guns and cutlasses in the wildest confusion. Isidor and his companions, when they realised that they were being mistaken for a hostile invasion, promptly and emphatically declared who they were, which was a thoughtful proceeding on their part. After the commotion occasioned by the return of the Waiomgomo prodigals had subsided, Isidor paid me a visit and gave me the news. Of course no allusion was made to his defection. Even if I had had the desire I did not have the strength to quarrel with him over the matter, and what does one ever gain by quarrelling with a man over his religious scruples or superstitious fears? Besides, he had wisely thought of bringing a present of eggs and fresh provisions tastefully arranged in a basket, which he handed me with so much grace while he came to my hammock and anxiously asked how I felt, that I could not do anything else but thank him for his present. He told me of Facundo's death and related incidents of 
his trip: how he had killed a pauji at one spot and seen a tapir at another; and how he and Vicente had committed havoc among the morocotos at Piritu; to all of which I listened in a dreamy sort of way, until seeing that I was tired he went outside and slung his hammock between two trees close to the entrance of the hut.

During the three following days I improved sufficiently to be able to stand for a few seconds at a time. On the 20th (January) the boats were loaded. Early on the morning of the following day I was carried down to the boat prepared for me, and placed on the blankets arranged so that I might lie down comfortably. Then we bade adieu to Pozo Bravo and our island camp, and hurried down the stream aided by its powerful current. At two in the afternoon we reached the Caura and took possession of our hut on the bluff opposite the Nichare. 'That night the two Indians, Isidor and Vicente, and one of the Venezuelans, took the smallest boat and left us. TVe stayed three days at the hut, during which I improved slowly. On January 25 we left for La Prision, which we reached on the 28 th. 


\section{CHAPTER XIV}

La Prision, January 28-February 22, 1901-Peccaries-Method of camping - Water tortoises-Eggs of the water tortoise-Para-Orchids-Indian method of carrying loads-Flies and ants-Above the Falls of ParaTapir hunting.

WE reached La Prision, as I have said, on January 28. As I realised that it would be at least two or three weeks before I would be able to attempt a second journey, I dismissed the Venezuelans. I decided also to take advantage of Longacre's return to Ciudad-Bolivar to send two of my Trinidad men with him, one of whom, the East Indian, was suffering from abscesses, the other from chronic laziness. Maite remained with me and kept our larder supplied with water tortoises and fish by spending his days on the river in Medina's small curiara. Pedro Hospedales and Asoque, who went by the name of Chichi, continued collecting birds. Freddy spent most of his time with a butterfly-net in his hands, adding to our entomological specimens. By February 10 I was strong enough to walk. Longacre was eager to get to CiudadBolivar, and as nearly all our provisions had been exhausted I determined to send some men with him to Puerto Antonio Liccioni to purchase the necessaries for our voyage beyond the falls of Para. For this purpose I engaged 'the Pirate,' Pancho Montenegro, and Ramon Ramirez. On the morning of the 12th the party left 
La Prision. I bade adieu to Longacre with feelings of genuine regret, for in addition to being a good companion he had nursed me through my illness with rare devotion, spending many a sleepless night near my hammock after a hard day's tramp through the forest. 'The Pirate' and his companions were instructed to return as quickly as possible after completing the purchase of the articles required for the trip. As Medina had an ox he wanted to get rid of, I bought it, and we prepared our own meat. The doomed beast having been tied by the head to the trunk of a mango-tree near the house, was stabbed behind the horns, dividing the spinal column. When his throat was cut some of the women caught the blood in gourds in which a little pepper and salt had been put. The clotted mass was fried and eaten as a delicacy. The tripe was thrown away. So far as I have been able to judge tripe is rarely eaten in Venezuela. After the meat had been cut into strips and salted it was dried for several days in the sun. Only one incident worth recording occurred after I had sent to Puerto Antonio Liccioni for supplies. One day at noon the clearing was invaded by a band of peccaries numbering at least 100 individuals. In a moment the whole settlement was in an uproar. The peccaries scampered about, grunting and uprooting the provisions; the men shouted; the women shrieked; while the boys and girls yelled. Had the settlers been properly armed quite a number of the animals might have been killed. As it was four were secured before they took to flight. Some of the men followed them into the forest and slew three more. That day and for a couple of days after we feasted on peccary.

'The Pirate' and his companions returned from Puerto Antonio Liccioni on the 20th. The 21st was 
spent repairing the boats and getting everything ready for our start on the following day.

When we left the settlement on the 22nd our party consisted of fourteen men with three boats. The Indians who had formed part of the expedition to the Nichare, with the exception of Maite, refused to go with me on this occasion. They said the dry sesaon was coming to an end, and should the rains set in early we would be unable to cross the falls of Para on our return, which would mean death from starvation. Although I realised that there was a good deal of reason in their arguments, I determined to make the attempt. Besides Jacobson and Villegente there were in this expedition the three men from Trinidad, Pedro Hospedales, Freddy Hospedales, and Pedro Asoque; the Venezuelans from La Prision, Pancho Montenegro, Epifanio Muñoz, Juan Silva, Laureano Rodriguez, Ramon Ramirez, Mateo Ramirez and his son, and Luis Urbana, alias 'the Pirate.'

The river was so low that we were able to ascend the rapids of Mura by the channel of Cinco mil pesos. Maite told us that he did not remember ever having seen so little water in the Caura. At night we encamped on an island at the head of the rapids. For Jacobson and Villegente, and the other men whom I had brought from Trinidad, pitching camp was an easy matter not occupying more than a couple of minutes. In addition to his hammock each man had a long oil-cloth. By tying a pole between the two trees to which the hammock was slung, the oil-cloth could be placed so as to afford complete protection from rain. The Venezuelans who were not similarly provided were in the habit, if the weather happened to be rainy, of building ranchos under which they passed the night. Poles being lashed to four trees 
in the form of a square, support the rafters upon which either palm-branches or the long broad leaves of the wild banana are strewn. Such a rancho can be constructed in less than half an hour, and when the hammocks are slung between the trees, beneath the thick covering of branches, with a big log-fire outside, the place looks quite snug and comfortable.

As I have already described the Caura as far as the mouth of the Nichare, any further description would be tedious. We reached the hut we had built opposite this affluent on February 26. Maite said that it would take three days to get to the falls of Para. Above the mouth of the Nichare there are numerous sandbanks and many rocks. The season had been a very dry one and the banks were in consequence fully exposed. At this time of the year these sandbanks are resorted to by numbers of water tortoises for the purpose of laying their eggs. These tortoises are called Terecays by the natives and are a favourite article of food. Different methods are employed for catching them. When the river rises considerably, so that the waters reach the vegetation on its banks, the Terecay may be speared while feeding off the leaves and young shoots of certain plants which are then partially submerged. Although the Terecay is shy, and to get near enough to use the spear requires a good deal of caution and skill, the Indians were usually successful whenever they went out spearing during the creciente, as the rising of the river is called. These tortoises are also caught with fish-hooks baited with meat. During the laying season on bright moonlight nights the tortoise hunters conceal themselves in the bushes at the river's edge adjoining some sandbank, where they await the arrival of the Terecays who come to lay their eggs. The 
reptiles like to get well away from the water's edge before they begin to dig the nest in which the eggs are to be deposited, so that the men are able to rush out and intercept them. The jaguar employs exactly the same method when hunting the water tortoise and other turtles. The Indians on several occasions called my attention to the fresh footprints on the sand of this beast of prey, and once we came across the remains of a tortoise torn open and devoured only a few hours before our arrival. Considering how strongly joined together are the carapace and plastron of the tortoise, some idea may be formed of the strength required to tear them asunder, a feat the jaguar performs apparently with ease. The Terecay is a ferocious brute, snapping viciously at anything that comes in its way. This habit, joined to the distinctly snake-like appearance of its head, gives the creature a fierce repulsive aspect. Its flesh is however excellent, and I was always glad to have stewed Terecay for dinner. In all the Indian houses the carapaces of water tortoises and turtles are used as utensils for keeping various articles of food.

In hunting for eggs on the sandbanks the Indians are marvellously expert. I have often seen them stand up in the boat and point out spots where eggs were likely to be found. They rarely made mistakes. We obtained large quantities of eggs all the way as far as Para. Many of them were in the embryo state, some being far advanced, but this made no difference to the men, who ate every egg they found in a nest, whether fresh or not. There are times when the eggs of the Terecay are quite bitter. This is due, the Indians told me, to the tortoise feeding on a certain berry having an intensely bitter taste. The eggs are like a pigeon's in size and shape. As they get spoilt in two or three days, the Indians boil them for a 
long time and then spread them out in the sun. Thus treated they last much longer, but they lose in flavour.

By midday on March 1 we got to a part of the river having ranges of hills ruming parallel to the banks. These hills are offshoots of the plateau from which the Caura falls at Para. At some remote period this plateau must have extended to the spot where we were, perhaps farther, but the river had cut back to where the falls now are. Whenever the wind blew from the direction of Para we could hear the dull roar of falling water, which grew louder as we got nearer, until at last we were in sight of a foaming cataract tumbling and rushing through a deep gorge. Just above the falls the Caura divides to form an island of between seven and nine miles in length. By a succession of cataracts the two streams rush through gorges at each side of the island, to meet at its foot in a deep pool. The right-hand stream is of much greater volume than that on the left, which, after a severe drought, dries almost completely up. When the river is low the pool where the streams meet is calm, and its banks are stretches of beautifully white sand, with backgrounds consisting of coal-black rock supporting in places a vegetation of flowering shrubs and orchids. It is then a very lovely, peaceful-looking spot, even the roar of the falling water being subdued. I must confess that when I saw the falls for the first time I was disappointed. Although the scene was beartiful, it was not the picture I had conjured up when the Indians had described, with bated breath, the grandeur of Para.

We pitched our camp on the stretch of sand at the foot of the island. The weather was so dry that the men did not build any huts: they simply planted poles in the ground in triangles and slung their hammocks between 
them. It was truly an ideal spot for a camp. While I lay on the sand enjoying the beauties of the scenery, Maite, who like old Nestor delighted in telling stories of his youth, sat beside me, and related how his brother and four others of his tribe had perished in the pool many years before when he was but a boy. They had started from their home in the mountains at the sources of the Erewato with the intention of reaching San Pedro, where they expected to obtain knives, beads, and such other trifles as gladden an Indian's heart. When they got to Para they found that the river was in flood and the whirlpool looked dangerous; still five of the party determined to make the attempt in their boat. In describing the incident Maite made use of a series of impressive gestures. He pointed to the middle of the pool; he swept his arms round wildly; then he made a movement as of one about to dive, and he gasped like a drowning man; finally, he lay his head upon his hands and closed his eyes. The boat had been drawn into the whirlpool, had been swept round and round, and had then been sucked in. The men had struggled awhile, fighting wildly for that life we prize so dearly, but their efforts were vain. They had gone to rest with those who sleep eternally.

Perhaps some day the falls of Para will be put to a remunerative use. Considering that in the forest around are many valuable tropical woods, the erection of a sawmill in this spot might be a paying concern, but I do not believe that there is any chance of this occurring. in the near future. Personally I prefer to think of Para in its wild uninhabited beanty, than to conjure up the picture of some hideous timber building surrounded by hovels at the foot of the falls. 
On the day after our arrival Jacobson and I went with Pancho in the small boat as far into the main gorge as we could with safety. We landed on an immense mass of rock up whose slippery sides we clambered. From this spot we had a splendid view along the defile. Huge fragments of rock like the one we were standing on form the bed of the gorge. These fragments are of a shining black colour, and smooth and slippery, looking as if they had been polished with plumbago. With a continuous dull roar like the rumbling of thunder the water dashes down the defile, hurling itself against the masses of rock and breaking in foam over them. Jacobson took several views of the gorge, after which we returned to our camp. I noticed on the way many logs of from four to five feet in length, with their ends as regularly rounded as if they had been cut with some sharp instrument. In their passage down the gorge they had been ground against the rocks into this regular shape. We used some of these logs as rollers when we hauled the boats over the stretch of sand to the foot of the hill.

During the first three days after our arrival the men were occupied cutting a track through the dense forest which clothes the island up to the river above. On the morning of March 5 the tedious operation of hauling the boats overland was begun. We had two large boats, much of the same size, and a small one. Of the larger boats one was exceedingly heavy, having been dug out of very hard timber. The lighter of the larger boats was the first carried over the stretch of sand to the foot of the hill where the portage began. Then with a long stout rope and a pair of double pulleys, one attached to the head of the boat, the other to a tree some twenty or thirty yards in front, the boat was slowly hauled up over round logs 
placed crosswise on the track. The men sang lustily all the time, but this did not appear to aid them to any great extent in overcoming the difficulties of the first part of the portage, which is the steepest. By midday, when they came for breakfast, they had covered not more than 200 yards. Day after day the men toiled with the boats, Pancho, the cook, taking their sancocho to them in a large tin, so that they would not have to waste time by coming down to the camp in the middle of the day to eat. I did not accompany them but stayed in camp, suffering from fever almost every alternate day. Pedro Hospedales shot a good many birds, some of which had not been obtained in the collections made at La Prision and on the Nichare, and Chichi killed a male and female cock-of-the-rock ${ }^{1}$ both in beautiful plumage. Hawks were plentiful, and we secured many fine specimens. Attracted by the refuse from Pancho's kitchen they would come quite close to the camp, where they generally met with a violent end.

My rambles were limited to the foot of the hills that surround the pool and end in places in a perfect jumble of rocks. Many of these rocks supported magnificent masses of Cyrtopodium Andersonii and Epidendrum elongatum. Both orchids were in full bloom at the time of our visit, so were many plants of Cattleya superba, which is exceedingly abundant on the stunted moss-covered trees on the rocky islands and banks of the Caura. Our camp was in consequence always gay with flowers brought in by Pedro and Chichi, who were aware of my passion for orchids. Many lizards, several different kinds of insects, and a queer little frog inhabit the fissures of the rocks. These queer little frogs were particularly interesting to 
me. I did not observe them anywhere else except here, although they probably exist in other places on the river, but as we did not remain long in any other spot except Améha, I did not have the same opportunities of studying the smaller forms of animal life as at Para, where we stayed seventeen days. These sprightly little reptiles are from one to one inch and a quarter in length. They are jet black underneath, with the upper part of the body and head irregularly marked with orange-yellow bands and spots. What struck me most was that no two individuals appeared to be marked in the same way, each one having a pattern or design of its own, as it were. They make a chirping noise like a small bird, and they move about with extraordinary rapidity, protruding their long tongues for the purpose of catching small insects. If alarmed they disappear with a quick leap into some crevice, where they remain until they consider the danger over.

On March 9 the men told us that they had got two of the boats to a spot about midway between where we were and the river above. They said that it would save time and be less fatiguing for them if we would remove our camp to that spot, as they would not then have to make two long journeys every day. The heaviest of the larger boats had been dragged only to the top of the hill. On the morning of the 10th, the provisions and our other things having been made up into convenient packages so that they might be carried by the men, we all walked to our new camp, which we reached at about ten o'clock. Maite carried his load in true Indian fashion. As he had done when we explored Turagua, he constructed two oval frames, about three feet in length, of thick pieces of pliable creeper, with strips of bark woven between. Having placed one of these frames on the ground, he spread the 


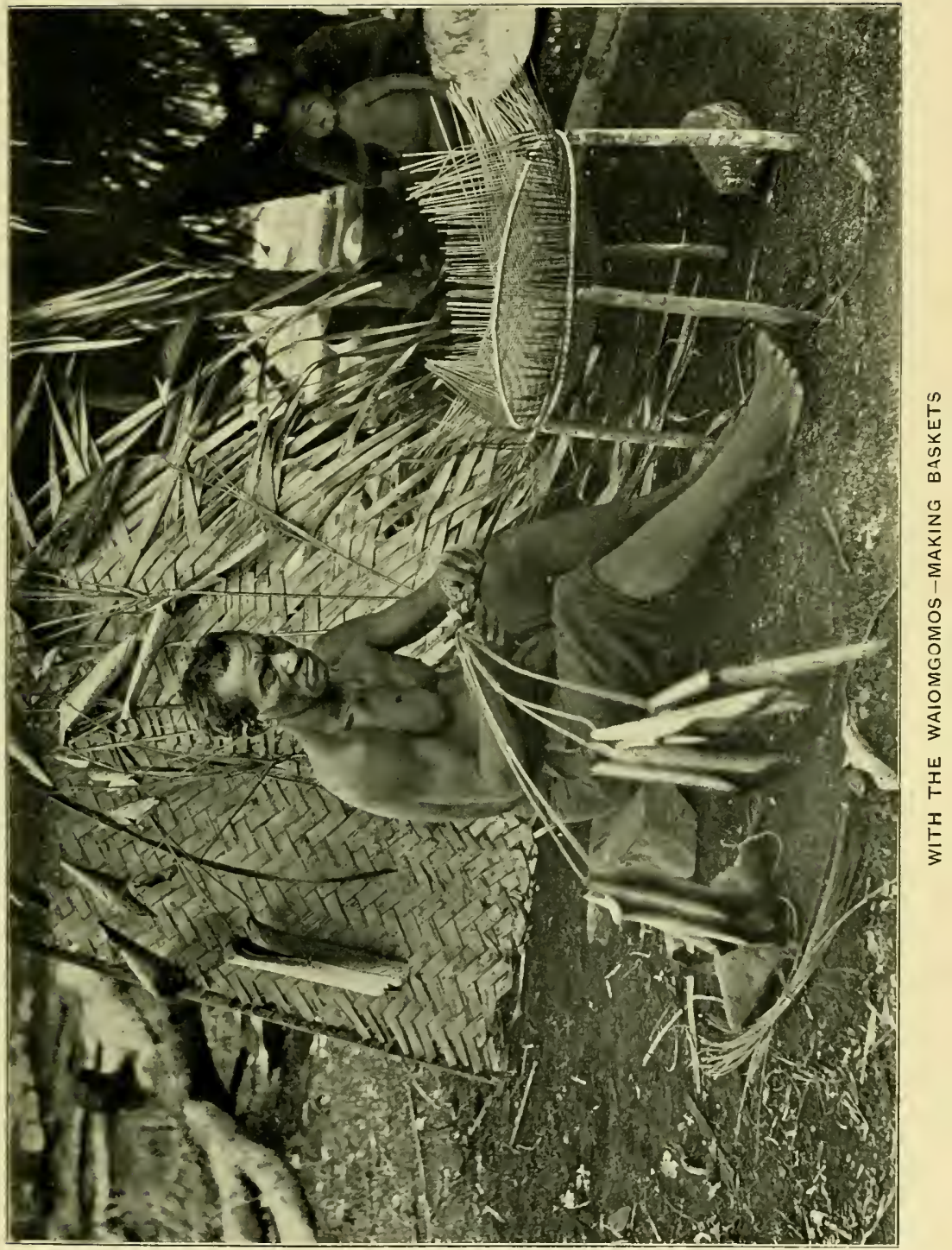



articles that went to form his load on it, after which he lashed the other frame securely to the one beneath. A broad band of bark was tied to the package and this he stretched across his forehead, allowing the pack to rest on his shoulders and back.

The method of carrying loads by a broad band across the head is, as I observed during my first visit, common to most of the American tribes; even men and women being carried across the mountains in chairs in this manner. The carriers throw the body slightly forward and proceed at a sort of trot, covering long distances with a considerable weight.

During the afternoon the men made another journey and brought the rest of our effects up. The whole of the island was so densely wooded that we had to make a clearing by cutting away the shrubs and smaller trees before we could pitch our camp. This was a simple affair, consisting of a low hut for storing our provisions, clothing, and other effects. For ourselves, as we expected to remain only a few days at this spot, we did not build any rancho. We merely spread oil-cloths over our hammocks, slung between two trees. When we arrived, and while the undergrowth was being cleared, we were kept hotly engaged brushing off the ants with which the place swarmed. A thick bed of rotten leaves lay on the ground, and this harboured vast hordes of these disagreeable insects, so that it was only after the place had been well cleaned that we were able to enjoy any rest. Even then not a day passed without our being stung several times. This damp gloomy forest teems with insect life. Besides ants, swarms of flies of different kinds used to visit the camp daily. So assiduous were they in their attentions that I often heard Jacobson, who is far from 
being a profane man, swearing vigorously in English and German alternately at everything connected with flies and ants. This abundance of insect life attracted a large number of insectivorous birds; ant-thrushes especially were plentiful, and we managed to secure a good many specimens. Of these ant-thrushes I think one of the most conspicuous is the white-crested Pithys albifrons, a bird common enough, but rarely seen except when the hunting ants (Eciton Sp.) happened to be abroad.

As I have already described these ants and the antthrusbes in one of the chapters on the fauna of La Prision, there is no need to refer to them in detail here.

We stayed on the island from March 10 to 17, the men being engaged hauling the boats through the forest. It rained a good deal, particularly during the nights, and once we heard peals of thunder in the distance. If our things got wet it was next to impossible to dry them, as the little sunlight which reached us through the branches and leaves of the trees gave no heat. Even our bird-skins and other specimens were with difficulty kept from spoiling in the humid atmosphere of this dense forest. Jacobson, some of the men and myself, had frequent attacks of fever, due, I suppose, in a great measure, to the dampness of the locality. We were all glad when on the morning of March 17 we started in single file for the river, where the two boats had been launched. We had been forced to leave behind the heaviest of the dug-outs, as it would have taken too much time to have carried it across also. At midday we reached the place where the boats were. The river at this spot is 1,000 feet above sea-level, and its bed for several miles beyond is one immense mass of rock. Some of the men remained in camp washing their clothes; Ramon Ramirez completed 
the repairs to the large boat, which had had a hole knocked through its bottom during the portage; 'the Pirate' and several others went out hunting with the dogs; Maite fished for Aymaras in the pool close by the camp, using pieces of meat for bait. He caught several of these voracious fishes, some of which were of a large size. The Indians say that the Aymara is never caught in the river below. On the other hand the Morocoto is not found above the falls; nor are electric eels. The large alligator is replaced by a much smaller species called Baba by the natives. In fact the falls of Para appear to constitute an effectual barrier between distinct forms of river life. The word Raudales as applied to Para is to my mind misleading, for the same word cannot be used indiscriminately with reference to Mura, Piritu, and Para. The former are rapids, but the latter is a succession of falls or cataracts. All the maps to which I have had access give no idea whatever of the country through which the Caura flows, although the course of the stream is tolerably correct. At Para the land rises abruptly some 800 feet to a plateau about 1,000 feet above sea-level, and this plateau in its turn rises gradually to 1,500 feet at Améha and to some 2,000 feet at the foot of the Merevari range. This tract of elevated country must be of considerable extent; it probably constitutes the whole of the most northerly portion of Brazil drained by the Branco and its tributaries.

It was almost dark when the men who had gone out hunting returned. They brought the welcome news that they had killed a fat tapir, which they had left on an island some distance up the river. Three of them went in the small boat to bring the meat into camp. In about an hour's time they came back with the head and the 
four legs cut off at the joints where they meet the body. The trunk they had sunk in a pool, placing heavy stones on it to prevent it from floating. They said that the meat would be all the better for having soaked for a night in water. A big log-fire had been made when the men brought the news that a tapir had been killed, so that by the time those who had been sent for the meat returned everything was ready for the intended feast. The head, with the skin left on, and without any preparation whatever, was placed on a sort of large gridiron made of green sticks. The meat was cut off the other portions in strips; through these strips green twigs were stuck, and the twigs being long enough were planted in the ground in a slanting position so that the strips of meat hung over the fire. The men sat around and recounted the day's hunt. Although they had seen many fresh traces of tapirs after leaving our camp, it was only late in the afternoon that they succeeded in surprising and killing the one whose flesh was simmering before us. Taken unawares the poor beast, it appears, had leaped into a small but fairly deep pool, where he was immediately surrounded by the hunters. Some of the men were armed with shot-guns, others had cutlasses, and 'the Pirate' carried a lance. The tapir, bewildered by the shouts of the men and the barking of the dogs, made no attempt to break through the circle and escape. Those who had guns discharged them at close quarters into his body; then the whole band closed in upon him and hacked him to pieces after the fashion of Brutus, Cassius, and company. 'The Pirate' claimed the honour of having administered the deathstroke, but he never succeeded in proving his case to the satisfaction of his co-assassins, so that the point remained a disputed one; and, as it was never definitely settled, it 
gave rise to a good deal of contention whenever tapir hunting formed the subject of conversation.

The men remained awake nearly the whole night gorging and talling. It was a weird scene-the ruddy $\log$-fire surrounded by half-naked men, the uncouth head of the tapir on the huge gridiron, the bits of meat stuck on twigs hanging over the flames. Anyone coming suddenly upon us would have believed that he had lighted on some camnibal feast. All the hard work of the past three weeks was forgotten, even the grumblers being happy. It is incredible what amount of food my men could consume. The four legs of a tapir represent a good deal of meat, yet in the morning nothing remained of what had been brought in but the head, reserved as a tit-bit-to me, massive and unsightly; to the men, delicate and savoury. The rest of the carcase was brought in early, and having been cut in strips and salted, was stretched on poles to dry in the sun. Meanwhile the boats were loaded and it was arranged that we should start immediately after the midday meal, so as to reach before nightfall a difficult spot necessitating a portage. 


\section{CHAPTER XV}

Guayarapo-Ayaima-Block-houses on the Erewato-Tapir huntingStrange superstitions-Achaba-The sun-bittern-Suraima-Dining under difficulties.

THE dry season had been such a severe one that there was but little water at the spot where the boats had been launched, and in order to reach the main stream we had to get out frequently and walk along the banks while the men hauled the boats over the shallows. It was late when we got to the mass of rock that runs right across the river, forming a natural dam. Through this dam the Caura flows by several channels, but by none of these channels was it possible, at the time of our visit, to ascend the river. The boats were unloaded so that everything might be in readiness for the following day. Where we had pitched our camp was a very picturesque spot. Below the immense mass of rock over which the river rushes lay a smooth deep pool of considerable extent, with banks of white sand dotted with clumps of trees surrounding it. Flocks of small parrots and numbers of macaws, always in pairs, were flying across the river repairing to their roosting-places. To see the macarv in all his beauty is when the setting sun strikes with its rays the rich roddish bronze of his outspread wings while he wends his way with his constant partner to the leafy bower where he passes the night.

It took the men the whole of the day (March 19) 
to get the boats and cargo over the dam. Pedro Hospedales and Chichi were in the meantime most profitably engaged adding specimens to my ornithological collection. They had come across an inga-tree ${ }^{1}$ in full flower where they obtained, besides other hummers, ten specimens of one of the amethystine humming-birds (Calliphlox amethystina). Although I had spent eight months on the Caura collecting birds, in 1897 and 1898, we never obtained any examples of this humming-bird, nor did we during the whole of this expedition meet with any except on this occasion. The rocky bed of the dam over which the river rushes was covered with a thick growth of Neolacis corymbosa. Wherever there were pools of greater depth, other aquatic plants, including a Nymphcea, existed. Small flocks of noisy jacanas had taken possession of these pools far from the haunts of men, and here many of them might have ended their days in peace had not my 'boys' decided that the cackling jacana deserves a place in every collection of birds.

We paddled steadily for a whole day, passing many sandbanks on which were families of terns of three or four individuals. These birds build no nest; they simply scoop a shallow pit in the sand where they lay their eggs, upon which they sit fully exposed to the burning rays of the sun. It was late in the afternoon when we reached that part of the river called Guayarapo. At this place the Caura widens out considerably and flows through hundreds of islands by a perfect labyrinth of channels. Many of the islands are of rock, with shrubs and stunted trees growing in the hollows like those at the rapids of Mura and Piritu; others of larger size are of earth, and they support a much more vigorous vegetation. While

1 Inga ingoides. 
on the moss-covered trees of the rocky masses Cattleya superba and some other orchids are abundant, none are to be found on the larger forest trees growing on the islands of alluvial formation. Curassows and penelopes were plentiful, and we saw tracks of tapirs everywhere. So abundant were the former that it was no unusual thing for us to kill ten or twelve of these large game-birds before we stopped for our midday meal. After leaving Guayarapo, the loveliest spot on the Caura is reached. The whole volume of the river rushes through a gorge not more than thirty feet wide, hemmed in by walls of shining black rock. The Indians call these narrows Ayaima. Above and below the passage, lake-like sheets, dotted with islands, add to the beauty of the scene. One can imagine that the stream gathers all its strength to force a passage through the iron barrier in front of it and then rests awhile before cutting its way through the tortuous channels of Guayarapo. While our midday meal was being prepared I wandered along the sand which forms a dazzling fringe to one side of the lower pool, the opposite bank being cliffs of dark rock mottled with grey patches. I felt that I would never tire of viewing from different spots the beauties of Ayaima.

Quite close to these narrows the Erewato falls into the Caura. The main stream above this point as far as its source is called the Merevari. Maite was unable to explain why the same river should be known by names so different, but he was very particular all the same, from the moment we passed the mouth of the Erewato, never to make use of the word Caura when speaking of the river. While we were in the vicinity of the tributary at whose head-waters our old Indian guide had passed the days of his boyhood, he described the country where he 
had been born and the village which he had left so many years before. From his accounts the Erewato must be an exceedingly difficult and dangerous river to navigate. As far as I could understand, this river rises in very mountainous country; yet his people were in the habit, he told me, of crossing over to the Manapiari, one of the tributaries of the Ventuari, for the purpose of trading with the Indians who reside on the banks of that river. This agrees with Humboldt's statement that in going along the River Padamo he noticed a road across the forests and savannahs which he was informed was the length of ten days' journey from Esmeralda to the sources of the Ventuari; and from those sources, by the Erewato the missions on the Rio Caura were reached. The history of this road is interesting, for on it had been established a chain of military forts consisting of block-houses, called casas fuertes, mounted with swivels and occupied by small bodies of troops.

The soldiers, left to themselves, exercised all kinds of vexations on the natives (Indians of peace), who had cultivated pieces of ground around the casas fuertes; and the consequence was that, in 1776 , several tribes formed a league against the Spaniards. All the military posts were attacked on the same night, on a line of nearly fifty leagues in length. The houses were burnt and many soldiers massacred; a very small number only owing their preservation to the pity of the Indian women. This nocturnal expedition is still mentioned with horror. It was concerted in a most profound secrecy, and executed with that spirit of unity which the natives of America, skilled in concealing their hostile passions, well know how to practise in whatever concerns their common interests. Since 1776 no attempt has been made to 
re-establish the road which leads by land from the Upper to the Lower Orinoco, and no white man has been able to pass from Esmeralda to the Erewato. It is certain, however, that in the mountainous lands between the sources of the Padamo and the Ventuari (near the sites called by the Indians Aurichapa, Ichuana, and Irique), there are many spots where the climate is temperate, and where there are pasturages capable of feeding numerous herds of cattle. The military posts were very useful in preventing the incursions of the Caribs, who from time to time carried off slaves, though in very small numbers, between the Erewato and the Padamo. They would have resisted the attacks of the natives if, instead of leaving them isolated and solely to the control of the solrliery, they had been formed into communities governed like the villages of neophyte Indians.

A few hours after leaving the Erewato we came across a rude Indian rancho or hut. It had all the appearance of having been abandoned only a few weeks before. Maite, without hesitation, pronounced it to have been the temporary dwelling-place of a party of hunters from the Waiomgomo village on the Merevari range. He said that when Isidor, some other Indians, and himself lived for several years at a spot a few miles higher up, which he subsequently pointed out to me, the Waiomgomos in their hunting expeditions had never, to his linowledge, wandered so far from their village. From the number of tapir and fish bones, and the quantity of feathers scattered about in the vicinity of the abandoned hut, the Indian hunters must have had quite a fine time of it.

On March 25, while getting through a short rapid, we very nearly lost the small boat and her cargo. Luckily the articles with which she was loaded were not 
of a kind to be spoilt by water. Almost immediately after leaving what had very nearly been a scene of disaster, we surprised a large tapir on some rocks in the middle of the stream. 'The Pirate's' dogs sprang overboard, and swimming to the spot forced him into the water. The men paddled vigorously, keeping the boats quite close to him while he headed for the shore, sometimes swimming, sometimes diving, and in his terror making frantic efforts to out-distance us. Whenever he rose to the surface the dogs would cling pluckily to his ears, rendering it difficult for me to fire. He was only a few yards from the bank when I got a good chance at the back of his neck, wounding him mortally. He turned right round and swam out into deep water, but his strength was failing fast, and all he could do was to keep his nose above water. The men determined to secure him before he sank. Maite caught him by the ears, 'The Pirate' made a slit through his snout, and Epifanio deftly passed a piece of rope through it and secured him to the stern of the boat. He was dead when we reached land.

The cutting up of a tapir's carcase was about the only piece of work over which my men did not waste time or grumble. In this instance the dressing of the meat was performed on a slab of rock close to the river's edge, two of the men standing up to their knees in the water. Attracted by the pieces of offal and clotted blood which floated from the carcase, many large fishes kept darting about, fighting for the dainty morsels. 'The Pirate' was severely bitten in the calf by one of these fishes. Judging by the howl he gave when the fish mistook his leg for a piece of tapir, and the agility he displayed in getting out of the river, I should say that the Aymara is blessed 
with a powerful pair of jaws. The men for hours afterwards unfeelingly chaffed the sufferer, and laughed at his lamentations. Close to the spot where the tapir was killed an island, consisting of open stretches of rock with patches of wood between, divides the stream into two channels. We stopped upon this island for the day, so that the men might salt the meat and spread it out to dry. The scene of gluttony I had witnessed at Para was repeated, the men eating as if they had bets on the result. I noticed also that the hoofs of this tapir, which happened to be a male, were divided, marked, and carefully stowed away, as had been done in the case of the other animal. The men explained that the scrapings of the tapir's hoofs possess extraordinary medicinal properties, but that particular attention must be paid to sex when administering this wonderful remedy. On no account should the scrapings from the hoofs of the male tapir be given to a man, nor should those from the female animal be administered to a woman. All the virtue possessed by this strange medicine is annulled if the important question of sex be disregarded. That is why the men were always careful to mark the hoofs so as to be able to distinguish between the masculine and feminine remedies afterwards. Many other supernatural properties are attributed to these worthless scrapings; such, for instance, is the belief that when a dog will not hunt he ought to be given a dose of tapir medicine. I was unable to find out how these absurd superstitions had arisen.

On the following day we were again lucky in killing another tapir. We had left our camping-place early and had paddled for about an hour against the strong current, keeping to the left, when we saw a tapir standing in shallow water on the opposite bank. The men lost no 
time in getting the boats across the river, but when we were within 200 yards of our prey he scrambled up the bank and disappeared in the bushes, to the intense disgust of my companions, who had looked upon him as good as dead. We continued paddling slowly towards the spot where the tapir had entered the forest until we were within sixty yards of the shore, when to my surprise and the joy of the men, the doomed creature walked slowly down the bank and stood on the open sand staring stupidly at the boats. Who were these strange beings who had invaded the unfrequented solitudes of his abode? His curiosity was the cause of his death. He fell where he had been standing, and died without a struggle. A few hours after his flesh, cut into long strips powdered with salt, was spread out to dry on a rocky island at the foot of the rapids of Achaba. Like Lot's wife he had fallen a victim to his curiosity; like Lot's wife a thorough salting was the punishment he suffered for wanting to know too much.

Our first camp at Achaba was at the foot of the rapids, where the river after forcing its way through a narrow gorge expands to the left, forming a deep calm pool bounded on one side by an open stretch of sand rising gradually to the hillock behind, and on the other by a ledge of rock separating it from the main stream. The scenery reminded me of that below the falls of Para, but the hill at this place is of much smaller dimensions. It had rained during the day, and when we arrived the sky was still overcast, so the men built several ranchos in which they slung their hammocks. Early on the following morning the work of getting the boats through the gorge was begun. We crossed over to the right, the bank on that side being less precipitous than that on the 
left, and the current not nearly so strong. At the upper end of the gorge the river tumbles over a ledge of rock in a fall of about four feet. The landing-places on both sides of this small waterfall are expanses of rock covered with fragments of all sizes and shapes, scattered about or jumbled together in the most complete chaos. It was a difficult bit of portage for a large heavy boat, and although the distance to the river above where the boats could be launched again did not exceed sixty yards, it took us until late in the afternoon to get them over. We encamped at the foot of another waterfall necessitating a longer portage, but this time the portage was through the forest over almost level land. From our camp we had a good view of a part of the mountain of Achaba. This was the first we saw of these solid square-shaped fortresslike masses which are so peculiar a feature of the landscape on the Merevari. From a high rock close to the waterfall above us there is a magnificent vista, the river dashing in white foam through the dark gorge to glide along the densely wooded banks beyond. The sombre mass of Achaba looming in the distance is a fitting background to the mixed beauty and grandeur of the scene.

I made a rather curious find at our camping-place. The same hunting party of Indians who had preceded us. of whom we had come across traces above the Erewato and at other spots, had left behind a queer hat of the exact shape of an ordinary straw hat, with the difference that it was not plaited of straw but of the stalk of the tirita (Ischnosiphon arouma), used in basket work, and the holes of the plaiting were quite as large as those of an ordinary cane-bottomed chair.

The day following our arrival at Achaba was devoted to cutting a track through the forest and laying logs on 
the ground for the portage of the boats. While this was being done Pedro and Asoque collected birds, and Jacobson wandered about taking photographs. By the afternoon of March 31 the men had got the boats and their cargoes overland to the head of the rapids, whither we removed our camp in order to be in readiness to start at daybreak. We left Achaba on All Fools' Day, as we were reminded by the Trinidad men, who tried all sorts of practical jolies on each other. We could have shot dozens of penelopes on our way had we landed on any of the islands, where whole flocks of these fine game-birds could be seen sitting on the branches of the trees or running about on the rocks.

Above Achaba the river for a considerable distance is smooth, broad, and deep. To the men this was always a welcome change to working in the rapids, which necessitated their being in the water the greater part of the day. In these deep parts of the Caura the banks are of earth densely wooded to the very water's edge, or with only a narrow stretch of muddy beach. These narrow stretches of mud are frequented by sun-bitterns ${ }^{1}$ and a species of ibis ${ }^{2}$ named koro-koro, after its call-note. On one or two occasions we also saw in such localities a pair of water-hens ${ }^{3}$ or a solitary heron of the variety known to the natives as pajaro vaca, ${ }^{4}$ the cow-bird, on account of its cry recalling by its depth of tone the lowing of a cow. Somehow the sun-bittern when in flight always reminded me of the hundred-eyed Argus and his unpleasant job of keeping watch over Io in her aimless wanderings through that part of the world known to the Greeks. On the Caura the sun-bittern is called Pavito

+ Tigrisoma lineatum. 
real, but it is better known all over Venezuela as Tigana. Sun-bitterns are easily domesticated and get quite tame. I have often seen them wandering about the houses and flying up on the dinner-tables to catch flies. They are expert insect catchers, rarely missing their prey. They have a curious habit of swaying their bodies from side to side in a listless monotonous manner, but the sight of an insect within range will at once call forth all theiv energies. A steady aim, a quick lunge of the pointed beak, and the victim is caught and swallowed. The korokoros interested us because they are such delicate eating. 'These birds appear to be naturally of a very shy disposition, for although they are never shot at on the Caura it is not easy to get within range of them. They have a peculiar jerky manner of moving their wings when flying, uttering at the same time the koro-koro from which they derive their name.

Four days' steady paddling brought us to Suraima, another difficult place to get through when the river is low. All day long the men hauled the boats up through narrow rapid channels or over masses of rock. It was terribly hard work, and we were all glad when late in the afternoon we camped above the rapids. On the following day we had our first view of Arawa, and where we stopped for the night on a shelving mass of rock the mountain loomed ahead of us in forbidding grandeur. Just before sunset the heavy bank of clouds which had been hanging over its summit cleared up, revealing the height of its precipitous sides and the fantastic shapes into which the plateau above had been cut. Maite caught an enormous Aymara, the biggest secured during the trip. He was such a monster that the men, after gorging themselves 


\section{DINING UNDER DIFFICULTIES}

with fish, actually left a piece over for the following day, a very unusual thing for them to do. We were forced to dine in the dark, any attempt to use a light attracting myriads of flies, which got into our eyes and dropped into our food. A steady drizzle fell the whole night and we had to use our oil-cloths. 


\section{CHAPTER XVI}

Colonies of hang-nests-We push on to Améha-The tapir-Accident to the large boat-First sight of Améha-Insects and a bright light-We kill another tapir-Iguanas-Améha.

WHEN we awoke in the morning the same sort of weather prevailed. Arawa was completely hidden by clouds, so that nothing could be done by Jacobson in the way of taking photographs. With the exception of one stretch where the current is strong, we found the rivel easy for navigation. Whole flocks of penelopes were on the open rocks, but in such places it was difficult to get within range. On landing on some of these rocks I saw a good many small slugs in the crevices and under the loose stones scattered about. Perhaps the penelopes feed on these slugs, and that would account for their visits to places which would otherwise appear to offer no attraction for such birds. The trees on the islands were in many instances used by colonies of hang-nests, who were rearing their young at the time of our visit. In fact, some of the trees were literally covered with nests placed so close together that it would be impossible to find room for an additional one. The biggest colonies were those of the yellow cassique (Cassicus albirostris) and the scarletbacked cassique (Cassicus hamorhous). It is a curious fact that these birds almost always hang their nests in close proximity to the hives of the marabunta. There must be some understanding between the birds and these 
terrible insects, otherwise how can we account for the hives and nests being sometimes so close together that the birds, in the frequent visits they make to their nests while feeding their young have to brush past the marabunta hives? There is moreover a good deal of resemblance between the nests and the hives. Both cassiques are favourite cagebirds in Venezuela, but the yellow variety, being commoner, is seen much more frequently in houses than the other. While in Venezuela the yellow cassique is called Arrendajo, it is known as Oropéndola in Colombia. Singularly enough many of the commoner birds are known under different names in the two republics, although the people of both speak the same language and are of common descent.

At about ten o'clock on the morning of April 7 we reached the mouth of the stream which flows from the direction of Mount Arawa, and bears the same name. It had rained steadily from daybreak and we were all wet to the skin. The men built a substantial hut and stored our things in it, as I determined, if it were possible to get close enough to the mountain by the stream, to make this spot a basis for its exploration. After breakfast Maite, Pedro Hospedales, Pedro Asoque, and myself ascended the stream in a small bcat. At the end of about an hour's paddling we reached a shallow rapid which prevented our going any farther. From the foot of this rapid we had a magnificent view of the stupendous precipice forming one side of Arawa. We were still at a considerable distance from the mountain, and I felt that with the limited time at our disposal we would never be able to cut a track through the forest to its base, and have time to go to Améha afterwards. With more water in the stream in which we were I have no doubt that it would be easy to get over the rapids and probably reach 
the foot of the mountain itself, but, as matters stood, it was necessary to decide between cutting a track through the forest to Arawa and abandon the trip to Améha, or push on to the latter mountain. Maite, who knew the country well, advised our going without delay to Améha. He said that although it would take us four or five days to paddle up the river we would have fewer difficulties to encounter in exploring Améha than if we remained where we were and attempted to get to Arawa. While returning to our camp I was attacked by strong fever, which lasted the whole night.

The Merevari, above where the Arawa joins it, has cut its way through beds of conglomerate, the banks being walls of masonry, as it were, with pebbles inserted in what appears to be a sort of cement. These pebbles are mostly of a dark slate colour, and are fairly uniform in size and shape. In the bed of the stream itself were banks of large round stones of a reddish-brown colour, over which the current rushed with such force that the men had to get out, and, wading up to their knees in the water, push the boats up. We saw Arawa several times during the day. At sunset we encamped at the foot of the rapids of Arichi.

Beds of large round stones similar to those seen on the previous day encumbered the river and made it difficult for us to get the boats over the shallow parts. There are three places in the rapids of Arichi where the river falls over ledges of from one to three feet in height. Every time we got to one of these ledges the boats had to be unloaded and the cargo carried overland. At midday we reached the last of these small waterfalls. The men were taking the things out of the boats preparatory to hauling them up, when there strolled ont of the bushes, quite close to where Jacobson and myself were sitting 
under a tree, a small tapir. I called out to Epifanio to get me my rifle, but in his excitement and haste he slipped and fell, and made so much noise floundering about in the water that the animal took fright and bolted back into the forest. He came out a little higher up and plunged into the rapids, where such an animal as a horse or a donkey would have been drowned in a moment. I could not but admire the ease with which he crossed the stream, avoiding the most dangerous parts, yielding to the current where he could not make any headway against it, and tumbling over the falls as if he were actually enjoying himself, and not swimming for his life. Finally he clambered up the opposite bank, and disappeared in the forest. It always struck me as strange that an animal so clumsy in build and apparently so unfitted for swimming should be so much at home in the water. The tapir is a singularly timid and harmless quadruped much preyed on by the jaguar. Were it not for the safety this powerful but defenceless creature can obtain by taking to the water whenever it happens to be attacked by some beast of prey, it is not unlikely that it would be very much rarer, if not actually extinct.

After the men had hauled the boats over the last ledge we found that it would be necessary to drag them for some distance across a stretch of shingle bristling with sharp pointed rocks firmly embedded in it. At this spot there was nowhere more than a foot of water, while in certain places the depth was much less, being a matter of inches. I pointed out to the men that it would be unsafe to attempt to get the boats over so dangerous a spot without laying logs under them to prevent their being injured by the rocks. I felt particularly anxious about the large boat, the one that had given us so much trouble 
at Para, and as I had noticed when we had repaired it after the portage that it was worn quite thin below, I could not help thinking that the least strain would cause a rent entailing a delay of days to make good. The men insisted that they would get the boats over without accident, and whenever they agreed on any point and made up their minds in a body I knew that it was useless to argue with them, so I let them have their way, praying devoutly all the while to the Goddess of Fortune to give us some luck. The trouble came when they had got about half-way through, and I had the grim satisfaction of having proved a true prophet. I had, in addition, the unsatisfactory pleasure of swearing at all peons in general and at mine in particular in the choice vernacular employed by themselves when they exchanged courtesies during a misunderstanding. The afternoon and the greater part of the following day were employed repairing the damage caused by the lack of foresight and prudence for which my followers were distinguished. It was fortunate that I had brought some carpenter's tools, nails, oakum, and pitch. We overhauled the old dug-out thoroughly and did the best we could with it, but I could not help noticing how worn and thin and rotten in places was the shell which carried us and our belongings.

On April 10, at about two o'clock in the afternoon, we got to the mouth of the Arichi. This affluent, like the Arawa, takes its name from the mountain where it rises. What ought to have been our midday meal was cooked on a large bare mass of granite so situated that we had a good view up the Arichi on one side and down the Merevari on the other. A sharp bend in the course of the main stream prevented our seeing anything in the direction of Améha; the grey cliffs of Arichi, however, were 
plainly visible, but this mountain is not nearly so imposing in appearance as Arawa.

It was nearly four o'clock when we finished our meal, and although the spot where we were would have made a good camping-place, I determined to paddle up stream until dark. I was eager to get a first glimpse of our destination, so long looked forward to, so difficult to reach. We took our places in the boats and I hurried the men on, setting the example by paddling vigorously myself. Almost suddenly we shot round the curve well out into the stream, and this gave us a clear view ahead for a considerable distance. Maite stood up in the stern and, pointing in front of him, said in a deep solemn tone, 'Améha.' Veiled in bluish haze the outline of the object of our journey could be dimly discerned in the distance. We might have taken it for some fantastic cloud had we not been told that it was a mountain. We stopped for the night at an abandoned camp of the Indians who had preceded us. It was by far the most elaborate of the many affairs of the kind we had seen on our journey, so that it would appear that the Indians had sojourned longer here than anywhere else. All the other huts we had passed on our way were flimsy constructions rapidly put together, but the three at this place had evidently been built with more care. An additional evidence of the Indians' stay at this place having been a prolonged one, was the large quantity of bones and feathers scattered around the huts. Jacobson, who wanted to change his plates, converted the smallest of the huts into a dark-room by tacking blankets on to the uprights. He afterwards took several flashlight photographs of the men sitting round the camp-fire roasting some large Aymaras caught by Maite. A curious result of Jacobson's. 
use of the magnesium light was the invasion of our camp by numbers of moths and other nocturnal insects, of which I secured more than 100 specimens. On the following morning I observed around our camp-fire the singed and mutilated remains of many of these moths and insects. They had evidently visited us in numbers during the night and had perished miserably, lured by that strange spell which a bright light casts upon them.

It is exceedingly interesting to observe what takes place when a bright light is used for the first time in some locality. When the electric light was installed in the streets of Port of Spain, the ground under the lamps used to be strewn with various kinds of insects. Of a sort of giant water-bug ${ }^{1}$ in particular. such numbers were destroyed that the insect came to be generally known as the electric beetle. In fact, I am not quite certain but that there were some people who connected the establishment of the electric light with the generation of this bug. These bugs no longer visit the lamps in numbers, so that either the species has got scarce through the destruction of the greater part of its members, or the survivors have learnt that visits to the lamps end fatally. It may be, also, that certain individuals are exempt from the fascination a bright light has for the rest of the species.

Another very curious result of electric lighting in Trinidad is that the bats have loarnt to malie use of the lights for catching moths and other insects. They fly about in the vicinity of the lamps, having discovered that their prey is more abundant there than elsewhere, and they intercept their winged victims on their way 
to the dazzling goal that so strangely attracts them. During several consecutive nights I observed one of our small owls ${ }^{1}$ hunting in this fashion. He had taken up his quarters in a tree close to one of the arc-lamps. From time to time he would dash out and capture a moth, returning rapidly to his place of concealment so as to be ready for the next comer.

Shortly after leaving the abandoned Indian camp we saw a tapir disporting himself in shallow water close to the shore on our right. He saw us also and scrambling up the steep bank disappeared into the forest before I could fire a shot. 'The Pirate' landed with his dogs and started in pursuit. We on board could tell by the yells of the hunter and the furious barking of his fourfooted assistants that they had come upon their quarry suddenly. We could distinctly hear the snapping of the boughs as the terrified animal dashed wildly through the dense undergrowth clothing the banks of the stream. For 200 yards he ran along the river. Then he came into view with a bound and stood for a moment on a projecting mass of rock overlooking a deep pool. The dogs, now thoroughly excited, did not give him much time to think, and the pursued and his pursuers leaped into the river together. The Merevari is broad and deep at this part, so that we felt certain of heading our victim off before he could reach the opposite shore. The men bent to the paddles with a will, shouting and encouraging each other. In our excitement we lost all control over ourselves, possessed by one passion, the desire to kill, and this caused me in my eagerness to fire while the tapir was still some distance from the shore. I must have killed him outright, for he sank at once,

1 Glaucidinm phalcnoidles. 
leaving only a few bubbles and a blood-stained patcl where he had disappeared. In a few moments these fleeting traces of his existence had melted away and no vestige remained of the bloody scene in which we had taken part. The men cut long poles and paddled slowly up and down trying to locate the carcase, but after many unsuccessful attempts they decided to sit on the rocks at the edge of the pool and await the floating of the body, which they said would take place in an hour or two. The dead tapir came to the surface at some distance from the spot where it had sunk, so it must have drifted with the current. The men lost no time in cutting the meat up, and we then continued paddling up stream with Améha in view almost all the time. At night we encamped at some abandoned Indian huts similar to those we had used so frequently during our journey, but these having been constructed hastily were already falling to pieces. We were now so near to Améha that we could plainly distinguish the details of the cliffs and the bare streaks along them showing where the water falls during the rainy season. With one exception, and that a mere thread of silver, the watercourses were all dry at the time of our arrival.

For several days I had had occasion to notice how abundant a certain kind of iguana is all over this region. These reptiles appear to live mostly on the branches of leafy trees overhanging the river. In colour they are so much like the foliage in which they conceal themselves that, were it not for their habit of leaping into the water just in front of the boats, we would, in nine cases out of ten, have passed by them without suspecting their existence. When they dive they do not rise to the surface, but return under water to the shore and hide in 
the tangled roots and dense undergrowth of the banks. I had many opportunities of observing the iguana at Panama, where it is used as a regular article of food by the natives. In fact, the principal occupation of the man in whose hut I lived when I was collecting birds on the Isthmus, was the catching of iguanas. He used to tie them all over the place until he had a sufficient quantity to take to town. Many were females literally bursting with eggs. These eggs may be seen in any of the shops in Panama tied by the middle in long strings, looking somewhat like small heads of garlic.

On April 12 at noon we stopped for breakfast on an open stretch of rocks with Améha in front of us. From where we were the slopes leading to the precipice seemed to begin quite close to the river's bank opposite to us, but when we subsequently explored the mountain we found that this was not so, there being a wide stretch of low-lying land between the river and the mountain itself. The top of Améha is almost flat and is densely wooded. Between this forest growth and that on the slopes below, the cliffs, with the exception of some projecting ledges which support a few shrubs and grasses, are bare and of a yellowish-grey colour, with reddish streaks or patches where the surface has been freshly exposed by the breaking off of pieces from the main mass.

After breakfast we continued our journey up stream in search of a suitable camping-place, the men having to wade in the shallow water and haul the boats after them. Finally we fixed upon an open mass of rock at the mouth of a small stream, and on this we landed our provisions and effects and prepared to pass the night. It was arranged, as we intended to spend several days at this 


\section{A NATURALIST IN THE GUIANAS}

place, that the following day should be devoted to the construction of some substantial huts. At night we had our first experience of the weather at Améha. It thundered repeatedly and rained in torrents. Maite told us in the morning that the spirits of the mountain, aware of our arrival, had warned us to go away. 


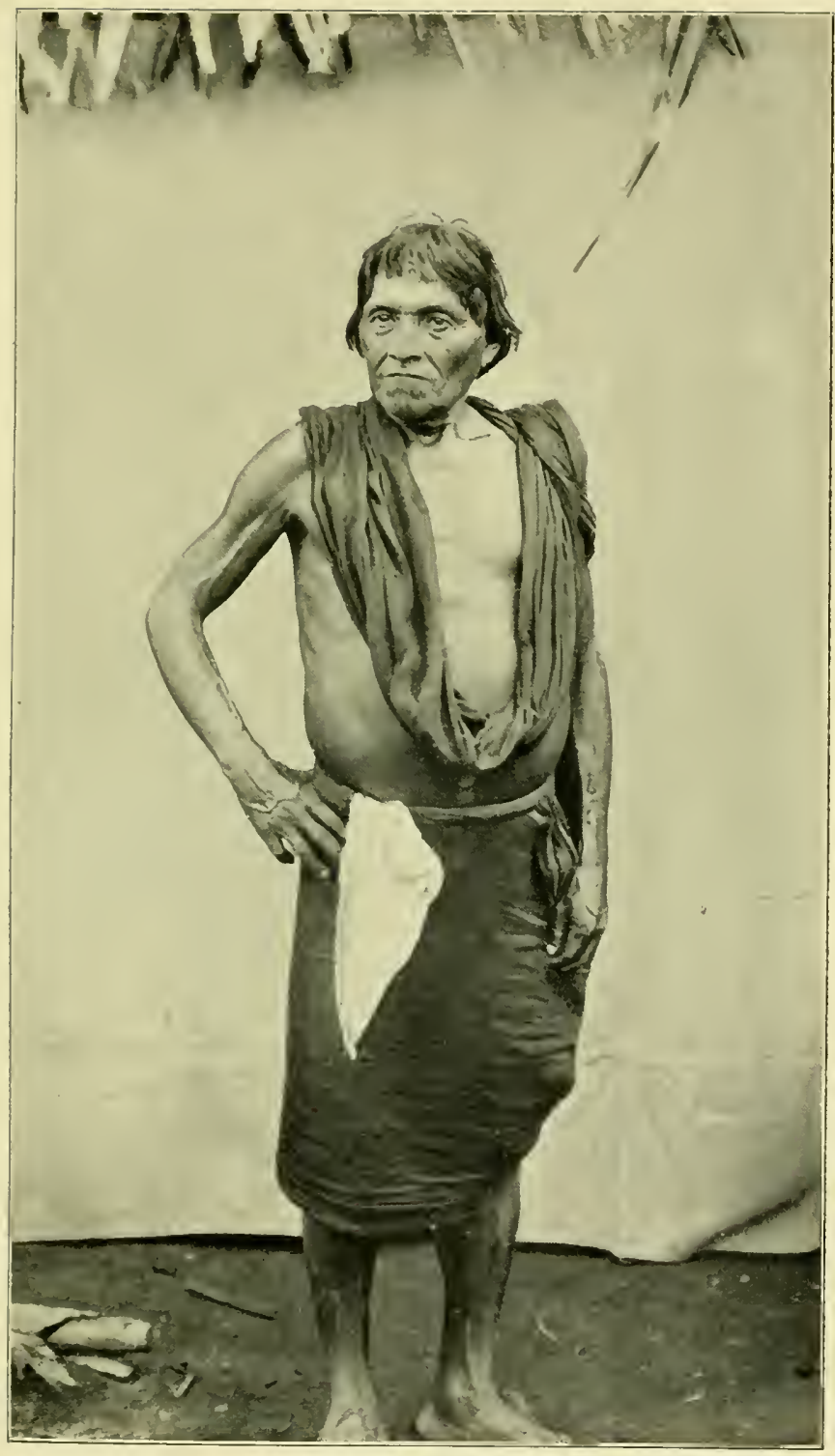

MAITE, THE GUIDE WHO AFTERWARDS DIED OF STARVATION 



\section{CHAPTER XVII}

\section{AMÉHA}

Inaccessible mountains - The koa bird-Concerning our taxidermistJourney to the cliffs-At the foot of the cliffs-Storm at night-We return to our camp-Further attempts to scale the mountain-We leave the mountsin.

WE may imagine that at some remote period in the past the greater part, if not the whole, of the region through which the Merevari flows was one vast mass of sandstone of considerable thickness overlying a formation of granite now exposed all along the river's banks and in various parts of the forest. A vague idea is all that we can form of the incalculable length of time during which this stratum was deposited grain by grain. When we consider that there must have been a subsequent upheaval of this immense bed extending over ages, followed by slow denudation which has removed the greater part of its mass, we find it difficult to form any conception of those epochs of time in the life of our planet that may not be expressed by figures. Améha, Arawa, and Arichi stand as monuments of what can be effected by the agency of water; they are evidences of the great changes that have taken place gradually on the earth's surface; they have remained as proofs of the alterations brought about, inch by inch, on the face of our globe during periods of time appalling to think of. One is tempted to believe at first sight that the awe-inspiring precipices and forbidding chasms of these inaccessible mountains must have been 
the work of titanic forces at a time of violent change, but if we speculate calmly on the erosive power of the streams in this region of heavy rains, we can imagine how immense areas of the country have been washed away, leaving these strange mountains as mementoes of an incalculable past.

The best known of these so-called inaccessible mountains scattered over a large extent of the Guianas is undoubtedly Roraima. Since the Spectator for April 1877 wrote: 'Will no one explore Roraima, and bring us back the tidings which it has been waiting these thousands of years to give us?' the mountain has been ascended and the secrets of its summit laid bare. To the Quelch-McConnell expeditions is due the honour of having performed the most valuable scientific work in the exploration of this interesting mountain. Considering that Roraima is only one of a whole series of such masses, the existence of some of which may not even be suspected, we can form some idea of what yet remains to be done in the exploration of this little known part of South America. When we consider, moreover, that the summits of these masses are plateaux isolated from the surrounding country during countless ages, we cannot help thinking that each of them must be a field of absorbing interest to the naturalist and botanist.

Where we had pitched our camp it was impossible to see Améha on account of the height of the trees of the forest which stretches to the mountain and clothes its slopes as far as the cliffs. The day after our arrival and a part of the 14th (April) were devoted to the construction of our huts, which were completed a little before noon. We then had our midday meal, and as three of the men had been employed cutting is track through the forest 
while the others were building the huts, I determined to follow the track for some distance and see the sort of country that lay between us and the object of our journey. Pedro Hospedales and Maite, who had been out hunting the day before, told me that to reach the base of Améha it was necessary to traverse a belt of low-lying tangled growth of much greater extent than would be supposed when the mountain is viewed from the river. The trees of this growth are stunted, and their trunks and branches twisted and unshapely. They are covered with mosses and parasites and appear to be always dripping with moisture. Besides other plants I noticed two varieties of begonia, some caladiums, and a Sobralia. Hillocks shaped like mounds are scattered irregularly over this low-lying strip of land. Although the elevation of these hillocks above the surrounding country is but slight, the vegetation which clothes them is different, and they are free from the deep holes covered with rotten wood and leaves which make walking in the low-lying part difficult and even dangerous. It was late when we started to retrace our steps to what we used to call home. We hurried along in the gathering darkness, stumbling over the matted roots and broken branches which impeded our march through this wilderness of weird ghost-like trees. We were all glad when we caught sight of the glare of our camp-fire. Hastening on we were soon seated within the bright circle of light where the men, squatting in groups, were eating their dinner. For the first time I heard in the gloom of the forest on our way home the strange cry of the bald-headed cotinga. ${ }^{1}$ Maite told me that the Waiomgomos call this bird Koa, which sounds very much like the Demerara name Quow. The unearthly

${ }^{1}$ Gymnocephalus calvus. 
note of this queer-looking bird is in accord with the misshapen trees, all twisted and turned, he has fixed upon as his abode.

Up to a late hour at night we discussed plans for the projected exploration of the mountain. Finally it was decided that five men, including Maite, should accompany me, and that we would take provisions for three days, our blankets and hammocks, and a change of clothing. Pedro Hospedales, his son Freddy, and Pedro Asoque were to go out collecting birds every day until my return. I entrusted the labelling of the specimens to Jacobson, the preparation of the skins being Villegente's work. I never cared to leave my taxidermist to his own devices, for if ever a man required strict supervision in his work it was this apathetic creature, whose existence appeared to be divided between eating and sleeping. The owner of an insatiable appetite, he was possessed by a drowsiness, with lucid intervals at meal-time only, when he would be more wideawake and active than any other member of our party. With the last mouthful the yearning to return to his hammock would take possession of him, and if I happened to be away or engaged in some occupation other than watching him, he would hurry through his skins, spoiling most of them, so as to be able to get back to his beloved resting-place and doze the time away. Jacobson, who had a weakness for bestowing pet names on the members of the expedition, had christened this strange compound of hunger and sleep the 'Bird Carpenter.' For the eight long montlis I had him with me I racked my brains for some epithet capable of designating in a concise manner his abhorrence of work, his devotion to rest, and his capacity for absorbing food in any shape or form, but as I could not hit upon any one word 
significant of attributes so different, combined in one individual, I had to employ many forcible adjectives when I wished to encourage him to do some work.

We filed out of our camp a little after sunrise on the morning of the 15th (April) and by ten o'clock we reached the stream which flows at the base of the slope where we may say Améha actually begins. The men having opened a good track through the low-lying stretch of forest as far as this spot, we had performed the journey in fairly quick time. The water of the stream was clear and cool, and this tempted us to sit on its banks and have something to eat. We did not waste much time over our meal, and the men were soon busy ahead cutting a path up the incline. This was comparatively easy work, as the forest growth on the slopes is not of the tangled nature of that covering the almost level stretch we had left behind us, nor is there a dense undergrowth to contend with. I noticed that the ground was covered with a thick bed of leaves, and that branches, some of which were of considerable size, were scattered about in profusion. From time to time we caught glimpses of the cliffs towering above us. The wall of rock seemed so near that I expected at any moment to have the satisfaction of standing face to face with it and touching its cold bare surface. In this, however, I was deceived, for although we toiled all day long, when at last we pitched our camp late in the afternoon, that deluding wall appeared as near, or I should say rather, as far off, as when we had sighted it early in the day. The men attached poles to four trees in the form of a square, and upon them they spread palmbranches as a covering. They then slung their hammocks and mine between the trees, and so we passed our first night under the very shadow of Améha. 
Maite was quite disappointed in the morning that nothing had occurred during the night. He had vaguely prophesied that some dread calamity would be sure to happen to one, if not to the whole, of us, for having dared to violate the sanctity of the mountain of spirits, and now he had to admit he was at fault. This he did with a bad grace when the others laughed at his fears, and from the way he kept muttering to himself and shaking his head I felt that he was not at all satisfied that we had escaped the danger which he seemed to believe threatened us.

The morning was so foggy that we could not see very far in any direction, and the cliffs were completely hidden by the veil of mist which enshrouded us. This did not prevent us, however, from making a start. The incline was in places so steep that we had frequently to crawl on our hands and knees, helping ourselves up by holding on to the twigs and ferns forming the undergrowth of the forest. A peculiar feature of the vegetation was a small but very graceful palm not met with lower down. In fact, most of the shrubs and small plants I observed were different to those seen on the previous day. Where our camp had been pitched there were a few masses of rock. but as we now saw such masses everywhere, I inferred that we could not be far from the wall of rock off which they had been precipitated. TVe came almost suddenly upon the cliffs. For some time we remained at one spot, gazing up at the stupendous wall that barred our way. The fog had cleared up, so that we had a good view for some distance on each side, but what we saw was not encouraging. As far as the eye could reach the impassable barrier extended in awe-inspiring grandeur. 'Thus far shalt thou go and no farther.' 
I have seen many lofty peaks in the Colombian Andes. The double crest of the Sierra Nevada, clothed in perpetual white, is an imposing sight; but none of these peaks can inspire that sense of awe I felt, standing a helpless and insignificant atom at the foot of that mighty wall, beside which the most imposing monument erected by the arrogance of man would be but a toy. What epochs of time must have elapsed since the solid rock before which we stood had been deposited grain by grain at the mouth of some mighty river or in the bed of the ocean!

For hours we walked along the base of the cliffs, until we came to a deep narrow gorge with a small stream running along its bottom. The gorge ended abruptly in a perpendicular wall of rock down which the stream, along whose banks we had picked our way, dashed in an unbroken fall of considerable height. This was probably the thread of water we had noticed when we viewed the mountain from the river on the day of our arrival. As it was getting late we decided to return to our camp, so we followed the stream for some distance until we came to a part where its banks widened out. Maite said that if we cut across parallel to the cliffs we would hit our camping-place. For hours we scrambled over rocks and fallen trees, and I was beginning to fear that we had lost our way, when we struck the track we had cut in the morning about half a mile above our destination. The men had left their blankets and hammocks hanging around the huts. When we arrived myriads of flies which had settled upon them arose and kept buzzing around us until it was almost dark. These flies had deposited their disgusting larvæ on everything that had been left exposed, so that the men were busy until late passing their things over the fire. At dusk I shot a 
beautiful cock-of-the-rock which had alighted on a tree quite close to us, evidently with the intention of passing the night.

The spirits of Améha again allowed us to sleep peacefully, much to the surprise and disappointment of our old Indian guide.

Another long day was spent in a fatiguing but useless tramp along the base of the precipice, which confirmed the opinion we had formed on the previous day that the mountain could not be climbed anywhere in the vicinity of our camp. As we were quite fagged out, and it was too late to think of getting to the Merevari, where Jacobson and the others were awaiting us, we decided on spending the night where we were, to leave at dawn on the following day. On this last night of our stay at the foot of the cliffs we witnessed one of those terrific storms which, during the rainy season, are of almost daily occurrence on these mountains, and which have doubtless contributed to the widespread belief amongst the Indians that the craggy heights of Améha, Arawa, and Arichi are the abode of spirits whose weapons are the lightning, the thunder, and the storm.

The night, up to about one o'clock, had been oppressively still, so still that there was not even a rustle amongst the leaves. In the fitful sleep I had had up to then I had noticed every time I awoke how black and quiet it was. The first intimation we got of the approaching storm was a blinding flash of lightning accompanied by a clap of thunder so loud that we all sprang out of our hammocks. Almost simultaneously with the thunder came strong gusts of wind, causing our huts to sway from side to side, so that I expected to see them blown down at any moment. Flash of lightning followed flash 
with scarcely an interval between them. All the time there was a continuous roar of deafening thunder that made the ground tremble beneath us. The rain came down in torrents and the wind had increased to such a gale that heavy branches were being blown off in every direction, while now and again some old monarch of the forest, unable to withstand the force of the storm, would come down with a terrific crash. The men assembled in the largest and strongest of the huts. All we could do was to remain in one place and hope that no tree would fall upon us. Old Maite was in a terrible fright. Whenever there was a lull in the storm which allowed his voice to be heard he would tell us stories of the wicked spirits who inhabit these mountains, and how they got angry whenever men invaded their precincts. It would have been folly to have tried to explain to this hardened believer in gnomes and demons the phenomena of a thunderstorm. How long this battle of the elements lasted would be hard to say. Probably we exaggerated its duration. The storm ceased almost as suddenly as it had commenced. A few gusts weaker than the others and the work of destruction was being carried on lower down, the thunder dying away in the distance. When I first explored the mountain I was struck by the size and number of the branches strewn about the ground, but after having witnessed one of these storms I found no difficulty in accounting for this state of things.

The rainfall at Améha and in its immediate neighbourhood is, I should say, very much greater than that of the surrounding country, and that is saying a great deal, considering that in these equatorial forests the rainfall is heavy. In fact, the vigorous vegetation existing over a great part of tropical America depends for its luxuriance 
on the torrents of rain which for nearly three-fourths of the year are of daily occurrence.

When we returned to our camp on the Merevari on the morning after the storm the leaves were dripping with moisture and the hollows were pools through which we had to tramp sometimes up to our knees in water, so that by the time we reached our collection of huts on the river we were wet through and through.

Things had not gone smoothly during my absence. Jacobson said that he had had a severe attack of fever, and that the 'Bird Carpenter' had given him a good deal of trouble. I examined the specimens collected. Of mammals the men had secured several adouries (Dasyprocta acuchi), and some capuchin monkeys. Amongst the birds were four skins of the bald-headed cotinga, and some other species quite new to me. Two game-birds, a kind of partridge and a tinamu, were to my mind the most interesting things obtained.

It rained heavily from midday to about four in the afternoon. Jacobson, two of the men, and myself went in the small boat a little way up the river to a spot from which a very good view of Améha could be obtained. Several photographs were taken of different parts of the mountain, as we found it impossible to get the whole of it on to one plate.

Améha was in all its glory. 'The cascades which dwindle away to mere threads after several days of dry weather were broad sheets of silver. Although we were at a considerable distance from the mountain we could hear the roar of the falling water as it dashed over the cliffs into the abyss beneath. I noticed from where we were standing that there is a narrow cleft towards the southern cud, cutting right into the very heart of the mass. I 
determined to explore this gorge on the following day. As far as I could judge, if it were possible to get to the plateau above from this side, our only chance of success was up this opening. Everywhere else Améha presents an impregnable front that no human being can ever hope to conquer.

On the morning of the 19th (April), Mateo, Epifanio, and myself ascended the river in a small boat until we got to the mouth of a stream opposite to the chasm we had seen the afternoon before, and which appeared to flow from it. We found on the following day that this stream really did come from the gorge. We were unable to get our boat any distance up the little affluent on account of the quantity of logs lying from bank to bank across it, so we spent the afternoon cutting a track in the direction from which it appears to come. At night I suffered from an attack of fever so violent that in the morning I was unable to accompany the men in their journey to the mountain. When they returned late in the afternoon they told me that they had succeeded in getting to the gorge and had ascended it for some distance. They seemed to think that it would be possible to get to the summit of the mountain by this route. I passed another wretched night, alternately roasting with fever and shivering with ague, and was so unwell on the following morning that I determined to return to our camp, which we reached at ten o'clock. The men who had remained behind had been occupied on a small dug-out. It had been shaped and hollowed and was ready for firing, the final operation in the construction of these canoes. Unfortunately the men had chosen for this work a tree they did not know, with the result that all attempts to open the canoe met with failure, so unyielding was the 
timber they had hit upon. This was a really regrettable incident, as we were badly in need of an extra boat, our large dug-out being in such a leaky condition when heavily loaded, that one of the men had to be kept continuously occupied baling out the water which forced its way in through the numerous crevices in the sides and bottom of our worn-out craft. I would have liked to have built another boat, did I not feel that it would be unsafe to spend any more time at Améha. We had but few provisions remaining. The rainy season had set in almost suddenly and the river was rising daily. The men, afraid that we might be cut off at the falls of Para, had become openly mutinous. We did the best we could with the old boat, stuffing bits of cloth into the cracks and holes, and at nine o'clock on the morning of the 24th (April), we pushed off from the shore into mid-stream, with the massive bulk of Améha frowning upon us. We had tried to ascend it and had failed. The day was a fine one, so that we were able to distinguish every detail of the summit stretching to the south, serene and unconquered, in the bright sunshine of that April morning, and this added to the bitterness I felt at having failed in my attempts to scale it. 


\section{CHAPTER XVIII}

Our last tapir-Arawa and Arichi-The fatal April 27-Loss of the large boat-We arrive at a decision-A night of misery-Mateo bitten by a snake-Treatment of snake-bite-Slow progress through the forestThe men build a raft-The kosoibo--Sufferings of the men-Suraima - We begin to starve-In desperate straits-The men decide to separate.

THE men, who had been sullen for days, becarne quite pleasant. Maite told us all sorts of stories about the mountain. On its summit, surrounded by giant trees, was a lake so deep that no one could fathom it. Strange creatures, unlike anything existing in the country below, inhabit its waters. Hidden in the clefts and caves of its inaccessible crags were the gnomes and demons who keep watch over its sacred precincts. They were probably looking down upon us, rejoicing in our failure to reach their abode. For hours our old Indian guide beguiled us with the legends of his tribe regarding the mysterious mountain we had left behind us.

We had been paddling for some time and were looking for a suitable spot for cooking, when a curassow uttered its deep note quite close to the river's bank on our right. We determined to try to kill it, so we landed Pedro Asoque, who disappeared in the bushes with the idea of securing what would be a welcome addition to our breakfast. We were anxiously waiting to hear him fire, when one of the men shouted out 'Danta, don André, Danta.' Within a few yards of our boat, swimming rapidly with 
the current, was a full-grown tapir, which we afterwards found out to be a female. Where she had come from none of us could tell; but she had probably been disturbed by Asoque and had taken to the water for safety. To have killed her where she was would have been to have lost her, as the current was strong and the river deep. When she got some distance beyond the boat she turned and made a dash for the shore. Just as her neck and shoulders were well out of the water I fired. There was a splashing and floundering for a few seconds. Then she managed to scramble up the steep bank, and as she bounded into the bushes I fired again. She fell, and we heard her struggling on the ground, but by the time two of the men clambered up after her she had galloped away into the forest. 'The Pirate' landed with his dogs and they were soon in hot pursuit. I felt certain that she would take to the water again, as the tapir invariably does when hard pressed. She came out a good distance ahead of us, but as the stream is almost straight for a long way at this part, we were able to keep her in sight while she swam across, but we did not get near enough to fire, nor did we succeed in heading her off. In the long swim the tapir had across the river she had out-distanced the dogs, so we picked them up and, paddling to the spot where she had landed, we placed them on the fresh trail. In a very short time they bayed furiously, and we knew that they had come up with the wounded animal, now unable to go far. When she took to the water some distance below us we could see that she was being closely pressed by the dogs. She did not attempt to cross the stream but kept near to the bank, here densely wooded. Meoro, a big tawny nondescript mongrel of poor scent, but a very devil to hunt by sight, kept close to her head, biting at her 
ears. It was plain that she would not be able to go very far, so the men made a final spurt to head her off and kill her close to the shore. The terrified brute now saw the boat, and, shaking the dogs off, turned into a small creek, diving as she reached its mouth. It was the work of a few moments to get to the creek, only to find that there was no tapir, and to meet the dogs swimming aimlessly about, evidently puzzled as to what had become of the animal they had been following. Where had the creature gone to? Had she died below, or, rising beneath the bushes, had she eluded the dogs and got into the forest? Suddenly Epifanio, forgetting in his excitement all respect, clutched my arm and whispered in my ear, 'André, la Danta.' Close to the steep bank, hidden by drooping leaves, was the large uncouth head of the animal we were looking for, so motionless that it might have been a rock sticking out of the earth. Finding her strength fail, she had tried stratagem and had very nearly outwitted us. A moment after she was dead and we soon had her on the rocks. While the men were sharpening their knives, Jacobson was adding her to his collection of sporting pictures. He was more than usually careful. He did not let the carcase lie in the undignified position the men generally chose for the dead bodies of the animals he wanted to immortalise. In this case the old artist insisted on having her placed according to his own ideas, while he himself put a stone to keep her head steady. All this he did as a tribute to her pluck. When he moved away with his camera I thought I heard him murmur, 'After Landseer.'

The tapir we had killed was big with young. I was quite struck with the colour of this unborn animal, so different from that of the parent. The skin of the adult 
tapir of this region is covered with short, hard, mousecoloured hair, of uniform tint. In the young one I noticed that its skin was soft and its fur striped. Unfortunately I cannot remember the exact shades of colour, the original notes having been lost, but there was one thing which struck me very much at the time, and that was the bright lilac hue of the intestines of this young animal. The men were delighted at having obtained a becerro, ${ }^{1}$ as they called the unborn tapir. They evidently meant to have a feast when we should camp for the night. We fared sumptuously off tapir steaks. Then we turned our backs on Améha, with Arichi and the dark mass of Arawa in front of us. During the whole afternoon we had both mountains in view, and the day being a very clear one the contour of the masses was well defined, showing in bold relief the gigantic scale of their perpendicular cliffs.

We encamped at night at the abandoned Indian huts where Jacobson had committed such havoc among the moths when he burnt his flashlights. The men roasted the young tapir whole and feasted late into the night.

Early on the following morning we passed the mouth of the Arichi. Just before we reached this point I had my last look at Améha, an almost indefinable mass in the distance behind us. Arichi was partly covered with dense white clouds, and Arawa could not be seen from where we were. We shot the first set of rapids successfully. Then we got through the channel where we had had to stop for repairs on the up journey. We still had to face the difficulties and dangers attending the lowering of the boats down the three ledges in front of us. In spite of all our precautions we had a mishap at the very 1 Calf. 
first of the ledges, and again we had to repair the large boat, an operation which lasted until late into the night.

On the following morning we were astir early. The large boat was hastily reloaded, and it did not take us long to get to the second ledge. The men were in high spirits, for we were now well on our way homeward; in a couple of weeks we expected to be back at La Prision, to which place most of my companions belonged. On that fatal morning of April 27 no one of us suspected that in a few short seconds the work of months would be lost, and that for weeks we would have to struggle to reach that settlement which some were doomed never to see.

The following is an exact copy of the journal I kept from this eventful day, to that on which eight starving human beings, hardly able to walk, dragged their way into the settlement at La Prision twenty-eight days after, what happened during that time having been jotted down while the incidents were still fresh in my mind.

April 27.-Left early and reached the spot where we had had to unload in the afternoon and drag the boats over a shallow part encumbered with rocks when we ascended the river. The large boat was let down first, ropes being used at the bow and stern. Afterwards the small boat was also successfully passed over. It was about nine o'clock. The morning was so gloomy that Jacobson, although he intended to take pictures of the lowering of the boats at this spot, which is very picturesque, thought it useless to expose any plates. About 300 yards lower down there is a narrow channel through which we had passed without much difficulty on the up trip. Beyond, the passage is dangerous, and it was our intention to unload at least a part of the cargo before attempting the more rapid channel lower down. So free 
from danger did the part where we were then appear, that Jacobson and myself remained in the boat, when the men, having as usual got on to the rocks, proceeded to slacken the stern-rope while the bow was being gradually drawn down stream. How it happened it is now difficult, if not impossible, to say. Whether the men underestimated the force of the current, or whether the front man at the stern-rope slipped and dragged the other after him, they themselves have been unable to explain. I suddenly felt that the boat was veering round rapidly, while 'the Pirate,' who had fallen forward, was floundering in the water. The other man, unable to hold on alone, had let the rope go. It was over in a few seconds. With incredible speed we were whirled along into the big channel, the most dangerous part of Arichi, and I knew that all was lost. I felt the heavy crash as the boat was jammed against the double rock which divides the channel, and I was hurled out with violence, falling into the water beyond the rocks. When I rose to the surface I was some distance from the wrecked boat. The men from the smaller boat who were on shore were making frantic efforts to throw me a rope, but it always fell short and was carried away by the force of the current. I reached shore lower down. My first thoughts were about Jacobson. I knew that he could not swim a stroke, and that if he had fallen into deep water nothing short of a miracle would save him. But there he was, clinging on to the rock in front of which the boat was wedged, and thus protected from the full force of the current. The men after several trials succeeded in getting ropes across the channel and rescued him from his perilous position.

Then it was that I realised the magnitude of the disaster which had befallen me. It was in the large boat 
that everything of value had been placed for greater safety. The collection of birds made on the journey up and at Ameha, the first ever taken from that interesting mountain; my plants on which I relied to pay me for the expenses of the trip ; the seeds, insects, herbarium specimens, samples of rock, and, most valuable of all, the writing-case with my journal containing extensive notes, the work of months, had all been in the wrecked boat. Jacobson's series of views of Améha, Arichi, and Arawa, with numerous plates of scenes in the rapids and in camp, were gone for ever. The work of destruction had been thorough. The men were doing all they could to recover such articles as floated within their reach. Among other things they managed to get the large camera, a fine instrument, but when we examined it I found that it would be useless. The plate-holders, of course, had been ruined. Not a single piece of clothing did I save, not one of my blankets, nor my hammock. 'The Pirate,' whose things had been in the small boat, lent me an old jersey and a pair of drawers. We then turned our attention to the wrecked boat. Was it possible to save her? Through a long rent in her side a perfect cascade of water was pouring, showing how thoroughly she had been cleaned out. By using the long ropes we had, some of the men managed to reach the rocks against which the boat was jammed. All attempts to get off what was left of her proved fruitless. To crown our troubles it rained in torrents all the time. I did my best to reassure the men, who were thoroughly scared, although they probably did not realise the gravity of our position. We had but the small boat to depend upon. The few provisions we had saved could not possibly last for more than eight or ten days, and we were 200 miles at least from the 
nearest station where we could expect help. Between the scene of our disaster and that distant station which we meant to try to reach lay a stretch of impenetrable forest devoid of any human habitation. The river was rising daily. We would have to traverse many dangerous rapids. Assuming that we should succeed in reaching the falls of Para, might we not find that we had laboured in vain? I thought that it was fair to the men in a matter which concerned them as nearly as it did myself that they should be consulted. So I called them together and put the question before them with the view of getting the opinion of the majority. I pointed out that we might try to build a boat, as we had saved a couple of axes in the small boat, but that as this work would take us several days we would find by the time we were ready that our few provisions had been exhausted. There was another plan, which appeared to me to be the best. Besides the two men required to work it and the provisions and effects which it could hold, the small boat could carry two persons. The rest of the party would walk along the banks, the boat meeting them at mealtime and at night. As the men would have nothing to carry we expected to be able to make fairly rapid progress. Finally it was arranged that Ramon Ramirez with Maite. as patron should work the boat. As the Winchester rifle and my twelve-bore had been saved, with some cartridges, and as the men said that I could use these weapons better than anyone else, they decided that I should go in the boat along with Jacobson, who was unable to walk. A horn which 'the Pirate' had brought had been saved, and it was agreed upon that we in the boat should blow the horn at intervals so that the men cutting their way through the forest might not wander away from the river. 
Of the articles recovered a tin box containing paper intended for wrapping butterflies, and a piece of pencil, proved the most useful. Had we not saved these things I do not know how I could have kept a record of what occurred after the loss of the large boat. While we had been discussing our plans for the future, Pancho had been cooking some rice and beans. We made a hasty meal and then loaded the small boat with the few things we had left. There was still a stretch of rapids to get through before leaving Arichi. Ramon, Mateo, and Maite went with the boat, with instructions to meet us at the foot of the rapids. We walked through the forest, reaching an open spot at about five o'clock, where we decided to await their arrival. But they did not come, and when darkness set in we could tell by the glare of a large fire on the opposite bank that they had encamped for the night. There we were on the bare rocks without food or blankets, and there we spent the night in a perfect deluge of rain, a fitting end to such a day. Jacobson and myself, huddled together, passed the night at the foot of a tree. It was our 'Arbol de la noche triste'-our 'tree of the night of sorrow.'

April 28.-Day broke on a miserable dejected crowd, benumbed with cold and weak from fasting. The boat arrived early and the men made a big log-fire, around which we sat while coffee was being prepared. We dried the clothes clinging to our bodies by hanging over the fire, warming our chilled hands and feet at the same time. We had some boiled beans with our coffee, and then, as had been arranged, the men started on their tramp through the forest along the river's bank. Jacobson, myself, and the two paddlers pushed off into the stream, allowing the boat to drift with the current. We 
scanned the banlis as we went along for any articles arrested by the branches or roots of the trees. We recovered a box and a bag. The box was one of those which had contained bird-skins, but as it had not been nailed up it was quite empty. The bag had cotton-wool with a few Winchester cartridges packed in it. We passed several birdskins floating down the stream, but it would have been waste of time to have picked them up. It rained heavily most of the time, the gloom of the morning adding to our depression. I landed in the rain and managed to kill a curassow, the only one we heard for the day. At midday we stopped on an open stretch of rubble and cooked the curassow I had killed. The men straggled in from the forest about an hour after our arrival. After we had eaten we continued our journey. I realised with dismay that our companions in the forest could barely lieep up with the drifting boat. At mealtime they had described the difficulties of their march through the dense undergrowth clothing the banks of the river, rendered more difficult and fatiguing by the uneven nature of the ground. If on this first day of our journey, when the men were fresh we could cover but a short distance, how could we hope to reach La Prision!

When we were quite close to the mouth of the Arawa I shot a large capybara, which Maite prepared, whilc Jacobson and I went up to the rancho built on the up trip to await the arrival of the rest of our party. It was getting dark when we heard shouts in the distance. I despatched the small boat, which returned after some time with a part of the men, including Mateo Ramirez, who was lying down supported by one of them. The men lifted him out and placed him on a blanket on the ground, where he lay groaning and trembling. He had 
been bitten by a snake just above the ankle. The punctures made by the fangs were plainly discernible, but I noticed that there was no swelling whatever, so that I suspected he must have been bitten by a nonvenomous species, or that the penetration of the fangs had been so slight that no poison had been injected into the wound. To my mind the man appeared to be suffering from acute fright only, but his companions thought otherwise, and he certainly behaved as if his last hour had come. The friends of the terror-stricken man subjected him to the approved treatment for snake-bite. It was a regular torture. Ramon Ramirez directed the operations, assisted by the others, who seemed to take a cruel delight in the pain they inflicted. A strong creeper was wound round the sufferer's thigh above the knee, the binding being so tight that the creeper actually cut into the flesh. Then with a live coal one of the operators cauterised the injured spot until the patient howled with pain. A mixture of chewed tobacco and crushed garlic was rubbed into the wound, which was then bound up. After such severe handling it is not to be wondered at that the poor devil moaned throughout the night. Although he evidently suffered intensely, he had become quite easy in his mind, so strong was his faith in the treatment he had undergone.

April 29.-Mateo obstinately refused to be moved, although I offered to make a comfortable place in the boat for him. He said that everyone knew that to travel over water on the day after having been bitten by a snake meant death. The other men backed him up, so there was no help for it but to remain where we were, wasting valuable time, to suit the whims of my superstitious companions. By dint of arguing with the men 
I succeeded in getting them to start at midday. They took some rice and beans and those who had hammocks and blankets carried them. It was arranged that they should push on, covering as much ground as possible, and we would meet them on the following day. This I knew we could easily do, as we could travel ever so much faster in the boat than they on land. I spent the afternoon in my hammock, thinking over the disastrous occurrence of the 27th (April). Every moment some fresh loss would be brought home to me, intensifying the bitterness I felt when I recalled the events of that fatal day. At night I had an attack of fever which lasted until morning.

April 30.-When Maite went down to the spot where the boat had been moored he found her high and dry on the rocks, the river having fallen considerably during the night. We had to take all her cargo out, and after much trouble we succeeded in floating her. Jacobson was too weak to give a hand. Mateo either could not or would not assist. Ramon had gone on with the others, so as to make room for the sick man. Maite and myself were therefore the only ones able to work. It must have been past one o'clock when, everything being ready, we helped Mateo down to the boat. I could not help noticing how swollen his leg was, and as I felt certain that this was due to the tightness with which the creepers had been bound round his thigh, I insisted on cutting the ligature. There was much inflammation around the cauterised part, which had become an ugly wound.

When we started the sky was overcast and there was a slight drizzle which increased, after we had paddled for about an hour, to a steady downpour. We passed one of the spots where we had slept on the up journey. This was the place where Maite had caught the large Aymara and 
which commanded so fine a view of Arawa. There is a small rapid just below it, which we shot without difficulty. Although I did not expect to come up with the party in the forest so early, I told Maite to blow the horn. To our surprise we were answered by a faint halloo from the shore a little ahead of us. Was it possible that the men had only travelled that distance, or had something happened to one of them, and had he been left behind for us to pick up? Maite blew another blast, and again we were answered, this time by several shouts from different parts, showing that the men were not together, but were straggling loosely through the forest. We paddled on until we got well in front of the foremost of the stragglers, then we made for an open mass of rock, where we landed. Maite blew the horn several times to let the men know we had stopped and were waiting for them. 'The Pirate' was the first to arrive; the others dropped in singly or by twos. They described the march through the forest as having been most trying. Steep hills and deep gullies clothed with thorny shrubs and a tangled growth of creepers was the sort of country they had traversed. They were fagged out and disheartened.

May 1.-Many of the men complained of being so footsore this morning as to be unable to walk any distance. They said that we would never reach Para at the rate we were going, and I could not but agree with them. They then held a consultation and decided to build a raft. Although I felt certain that no construction of the kind would have the barest chance of getting through the rapids and over the falls ahead of us, I did not like to offer any adverse opinion on a matter upon which they appeared to have made up their minds. From where we were we could see on the opposite bank some Yagrumo 
trees, which the men said would suit our purpose. We crossed over in batches, the boat making three trips, and we established ourselves at the mouth of a small stream which the men considered a good place for constructing the raft. A party, headed by Ramon Ramirez, went into the forest and were soon engaged, as we could tell by the sound of the axes, cutting down trees. Jacobson, Villegente, Mateo, Maite, and Pancho the cook, remained in camp with me. Maite fished at the mouth of the stream and succeeded in catching four Aymaras, so for that day we had sufficient food. To add to our troubles it rained heavily the whole afternoon, and our camp was invaded by swarms of flies, which fell into our food and got into our eyes. It was impossible to drive them away. Although we killed hundreds their numbers increased until dark, when they went away almost suddenly, to return with daylight on the following morning. Heavy rain with lightning and thunder the whole night. The rainy season had broken upon us in full force.

May 2.-The men continued working at the raft, which was completed at midday; they then floated it out of the stream and moored it along the bank of the main river. It was arranged that we would make a start immediately after breakfast, so the men loaded the small boat, after which we ate some boiled beans, and those who intended going on the raft went down to the water's edge while we took our places in the boat. It did not take long for the men to find out that the clumsy affair they had put together would never float them down the river. As soon as they pushed off, the raft, unable to bear their weight in the strong current, began to sink slowly. Luclily this happened quite close to the shore, so that those on board reached land without difficulty, 
while the mass of logs floated away to be broken to pieces at the first rapids. The men, thoroughly convinced that their only chance of reaching Para was by walking, continued cutting their way through the forest, while we drifted with the current as we had been doing since we lost the large boat. Several shots were overheard in the forest, and when we camped for the night the men brought in three curassows and two penelopes.

May 3.-This morning we finished the little bit of sugar we had. There is still some coffee and tea left, a few pounds of beans and rice, and six or seven ounces of salt. In order to economise this very necessary article Pancho puts only a pinch or two in the soup made from the game we obtain. The food is so unpalatable that it is with difficulty I manage to swallow a few mouthfuls. Jacobson and Villegente, on the contrary, continue to enjoy excellent appetites. We remained in camp a long while after the men had started to walk through the bush, as we knew that we would easily catch them up. It must have been eleven o'clock when we paddled out into the middle of the stream, so as to get the full benefit of the current. Here the Merevari flows through densely wooded banks, rising to hillocks some distance inland. Shot a penelope with the Winchester : a lucky shot, considering the distance at which I fired. As we drifted along close to the shore I noticed many deep gullies partially filled with water. The sides of these gullies were clothed with a tangled undergrowth consisting mostly of creepers running along the ground and covering the small trees. These are the bejucales so difficult to get through. We came across the men struggling through one of these bejucales, and as there was an open stretch of shingle close by, we landed and waited for 
them. We were glad to get out and stretch our cramped limbs, while Pancho lighted a fire to cook the penelope I had killed. The men brought quantities of a yellow fruit called kosoibo. They had come across a tree laden with ripe fruit, and after eating as much as they could they had very thoughtfully filled their hats and the bosoms of their shirts. It was the first time I had seen this fruit, which in appearance is much like a lemon, but the rind is hard and cracks easily on being squeezed, exposing a soft white pulp enveloping two large flesh-coloured seeds. The pulp possesses an agreeable taste, being sweet with a slightly acid flavour. At the time I thought the kosoibo the most delicious fruit I had ever eaten. We also obtained at this place the core of a species of palm which is a very eatable vegetable when boiled. This palm does not appear to exist in the immediate vicinity of Améha. In fact, since leaving the mountain this was the first day on which we saw any, but I knew that we would be pretty certain to meet with it from time to time on our way. It rained all the time breakfast was being prepared, and as I was suffering from fever one of the men slung a hammock between two trees so that I might rest, and to keep the rain off he spread a couple of blankets over me. We hurried through our meal and again the men went on ahead, we in the boat following afterwards. My companions had recognised that if we meant to reach Para we could not afford to waste time on the way. We drifted down, stopping from time to time so as not to outdistance those who were cutting their way through the bush. It was quite late when we stopped for the night, those who had to tramp through the forest dropping in shortly afterwards, bringing four curassows they had killed on the way. Most of the men passed wretched nights. Having lost 


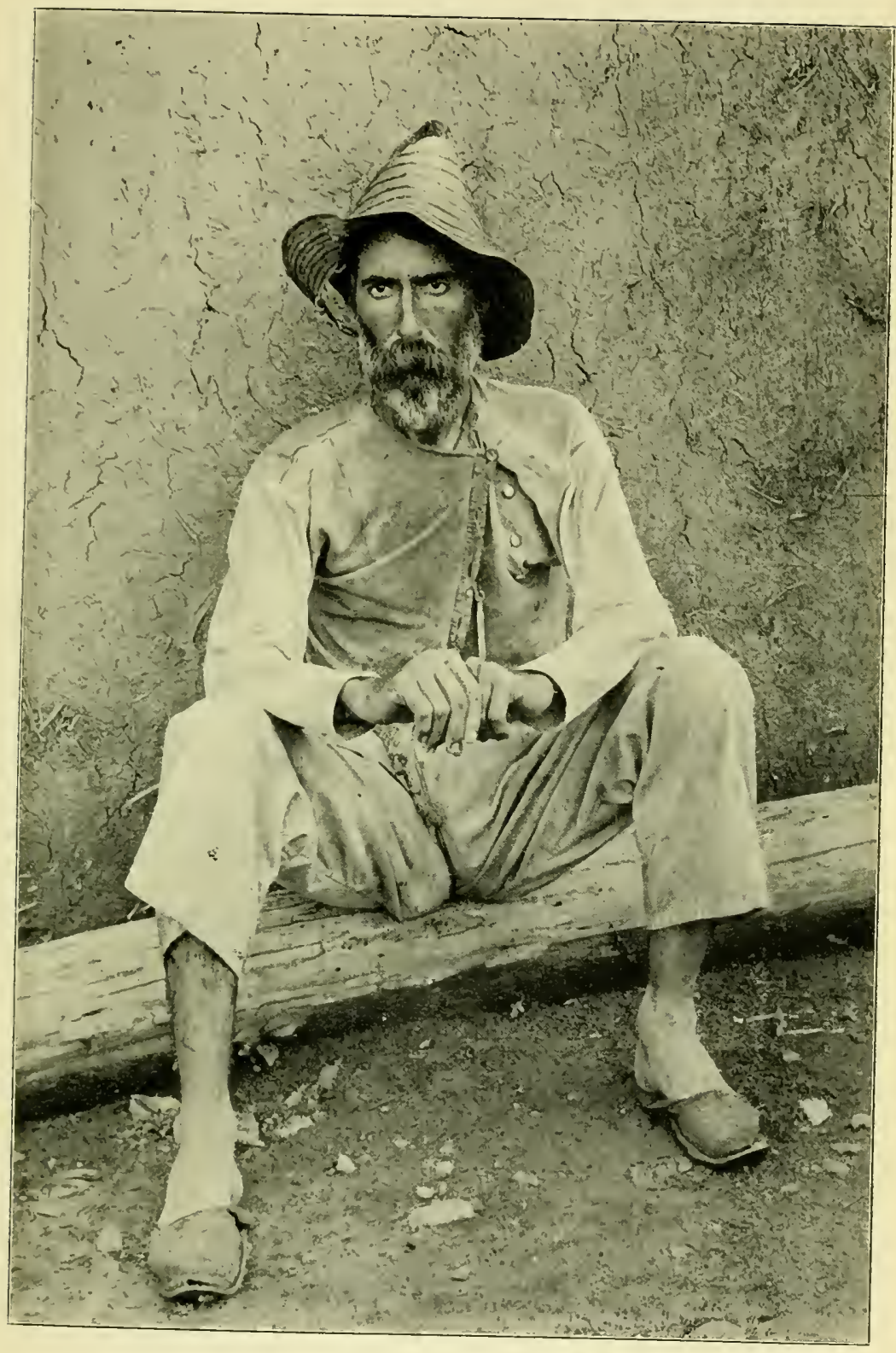

EUGÈNE ANDRÉ, AT LA PRISION MAY 1901 (AT THE END OF THE EXPEDITION) 

their hammocks and blankets they are forced to lie on the damp ground or hard rock, so that they do not obtain the rest they are so much in need of.

May 4.-Pieces of the raft my companions had built floated past our camp. Started early, drifting with the current, the rest of our party cutting their way through the forest. At about nine o'clock we reached our camping-place of the 4th of last month. How different it looked! When we had stopped here on the up trip the men had built several huts on the open stretch of sand and rock which then formed the river's bank. The whole place is flooded now, only the roofs of the huts being above water. It had been a cheerful-looking spot a month ago; now it has a desolate appearance. As we had heard no firing in the forest, nor any shouting, we dropped down stream a little; then we landed and blew the horn at intervals, so as to let the men know that we were waiting for them. When they joined us they brought no game. The Trinidad boys went into the bush and returned in about an hour's time with a curassow. This was boiled, and the water and bits of half-cooked meat divided up. The men would not go any farther to-day. They said they were tired and chilled, and that they wanted to build ranchos, so that they might have a dry night with fires. Some of the men have borne their hardships and privations well. Others have lost flesh and look quite haggard. Pedro Asoque and Juan Silva have their faces quite swollen. Freddy went out with my twelve-bore and killed a Marimunda, ${ }^{1}$ which Pancho roasted whole. It was then divided up and the men devoured the limbs like so many cannibals. At night Maite and some others tried to catch fish off the rocks, but without success.

1 A species of monkey. 
May 5.-We start without having eaten, as we cannot afford to use the few beans and the rice we have remaining except once a day. No tapirs have been seen since the one killed on the day we left Améha. I suppose that, as there is water everywhere in the forest now, the animals do not require to come to the river. Curassows and penelopes, seen in such numbers a month ago, are also getting scarce, and as the mating season has come to a close the birds do not call frequently, so that the procuring of game has become difficult. It rained all the morning, wetting us to the skin. Shot a small set of rapids, and passed an island I had named the Isle of Palms, on account of its vegetation consisting almost entirely of clumps of very graceful palm-trees. We waited for the men at the mouth of a small stream, Pancho cooking our midday allowance of beans. Maite blew the horn, as he was in the habit of doing whenever we stopped to wait for the others. The men had not obtained any game, but they brought a lot of kosoibos, and to me this was more welcome than the tasteless diet of meat and beans we were reduced to. The men always carried an axe with them in their tramp through the forest, so that they might cut down any large fruit-bearing trees they came across. It was still raining when we stopped for the night close to Suraima. The men were more fortunate in the afternoon than they had been in the morning. One of them had killed a curassow.

May 6.-Shot the rapids of Suraima, and stopped on an island to wait for the others. They did not come up to us until three o'clock in the afternoon, but they brought two curassows, and this made matters a little better. The spot we had hit upon was the only open one in the locality, but the ground and the scrub around were infested with 
a reddish stinging-ant which is one of the plagues of the region.

May 7.-We shared the last of the coffee this morning. The men went on ahead as usual, the rest of us starting about an hour after. A short while after leaving camp we saw an inga-bush laden with fruit close to the water's edge. Freddy climbed into its branches and threw the long pods to us. We greedily devoured the insipid pulp covering the large seeds of this bean-like fruit. Waited for the men, who joined us at about eleven o'clock. They said they had just passed a cahiman tree, and that they would return and bleed it. Maite told me that the milk of this tree is much used by the Indians, and that it is very nourishing. When the men, who had taken a large pan with them, returned they had almost filled it with a white coagulated stuff like clotted milk. This was the sap of the tree. Water was mixed with it and everyone took his turn at the pan. I drank but little of this liquid, finding it quite tasteless. Drifted down stream for about an hour, when we came to a creek which the men would have been unable to cross had we gone on without noticing it. While we were waiting for the others Maite cut down some palm-trees and we boiled the core, or cabbage as it is called. On the banks of the creek were some small trees covered with a purple berry in bunches. Maite called this berry fortin, and when the men reached us they also used the same word to designate it. We ate quantities of these berries, and as they happened to be very plentiful we filled our boat with them. When we stopped at night they served us for dinner. This day we passed many picturesque spots, of which Jacobson had taken views on the up trip, and this revived the bitterness I felt whenever I recalled the 
events of that disastrous day in the rapids of Arichi. How different was the scenery to that of a few weeks ago! When we had passed through these rapids on the up journey the day had been a hot sunny one. The river was then low, with exposed rocks and snags everywhere, through which the water rushed in foaming channels. The same place is now a flood of yellowish brown stretching from shore to shore, and is quite tame when compared with the scenery we had admired when the river was low.

May 8.- It was only towards morning that I managed to sleep a little. Up to about three o'clock I lay awake thinking, and the subject was food. All the markets I had ever visited were brought back to me with extraordinary vividness, from meat-laden Leadenhall to the little market at Panama, with its piles of bright yellow pineapples and its heaps of vegetables. Even when I dozed off it was to dream of food. Again it rained heavily towards daybreak, and this caused the men to discuss our chances of being able to pass the whirlpool below the falls of Para, should we succeed in getting so far. I tried my best to reassure them, although I could not help feeling anxious myself about such a contingency. By eight o'clock it cleared up and we paddled out into mid-stream to drift with the current, the others having started about an hour before. It was not long before we overtook them, but we did not stop until we reached the mouth of the small affluent, the Maivi. We landed on some rocks on the opposite bank as the men would require the boat to cross the stream, and we spread our soaked things out to dry. As we had heard four or five shots in the forest Pancho lighted a fire and put the pot full of water to boil, so that everything might be ready for cooling if the men brought any game. Mateo is much better now and can walk a 
little. It was nearly one o'clock when the first man to arrive called to us from the opposite bank. Maite and Mateo paddled across to meet him. Within half an hour all the men with the exception of Epifanio were in camp. It appears that he would persist in wandering away from the track the others were cutting in search of fruit. They had to wait for him repeatedly, they said, but eventually they had gone ahead and had not seen him for about two hours. Only one curassow had been killed and this was boiled in a good deal of water, so that there might be enough soup for everyone.

During the whole afternoon the men discussed our position, which we all felt was growing more desperate every day. I sent Pedro Asoque, Maite, and Freddy to look for Epifanio. They were to ascend the Maivi for some distance, the chances being that the lost man had reached the stream at some distance from the main river and was unable to cross. I told them to try to catch some fish or shoot something at the same time. When they returned it was quite dark. They had met Epifanio at some distance from the mouth of the stream, sitting in despair on a log of wood utterly at fault as to where he was. He told me that he thought he had been abandoned. As a matter of fact, Maite and my Trinidad boys were the only ones who were disposed to wait, even another day, if it had been necessary to search for him. The others, rendered unreasonable by hunger and anxious to be on the way, were for leaving him to his fate. Pedro Asoque had shot a duck in the Maivi. This was roasted and divided, each of us getting a small piece. The men sat around the camp-fire up to a late hour at night and held a consultation. They then came in a body to me with Ramon Ramirez as spokesman. He said that it would be im- 
possible to reach Para as we were going, and that even if we did get there, we would be so weak by that time that we would never be able to get the large boat we had left at the top of the hill to the river below. The men had decided that the best thing would be for those who were unable to walk and who were keeping the others back to hurry on in the boat so as to try to reach La Prision as quickly as possible, from which place a relief party could be sent back to meet the men left behind. By abandoning everything except the few hammocks and blankets remaining, one pot for cooking, and the guns, the boat might hold nine persons, leaving five to walk through the forest. Jacobson, Villegente, Mateo, his son, and myself would have to go in the boat, as none of us could walk any distance. Maite was the only one who knew the river sufficiently to act as guide, so that it had to be determined which would be the four to accompany us. At first the men spoke of drawing lots to decide who should remain behind, but they finally arranged amongst themselves that Pedro Hospedales, Pedro Asoque, Pancho Montenegro, Juan Silva, and Epifanio Muñoz should continue walking through the forest, and that 'the Pirate,' Laureano Rodriguez, Ramon Ramirez, and Freddy Hospedales should go with us. After we had arrived at this momentous decision we tried to get what rest we could. For the last time we slept together. 


\section{CHAPTER XIX}

Ve separate-Achaba-The giant armadillo-Dogs attacked by a pumaGuayarapo-Maite loses his reason-Death of our guide-Para-We leave Para-We reach Mura-Back at La Prision.

We were all up before daybreak. The men went to work silently, the impending separation appearing to have affected the whole of us. We drank some unsweetened tea, our only luxury, and we divided the few remaining pounds of beans and rice, leaving the greater part with those who were to continue marching through the forest. We shook hands with the five men, and then took our places in the boat. Laureano, 'the Pirate,' and Ramon paddled in front, Maite was steersman, the rest of us packed close together occupied the middle of the boat, sitting on the blankets and hammocks. Freddy had my twelve-bore handy in case we should come across any game on the way. For this reason and for safety we kept close to one of the banks all the time. So laden was our small dug-out that when we pushed off the slightest movement to either side on the part of any of us caused it to ship water. Hallooing a last adieu to the poor fellows standing on the rocks to see us off, who had many a weary mile of fever-breeding forest to tramp through, we were carried away by the swift current and soon lost sight of them. The river at this place is smooth and deep and its banks densely wooded to the water's edge. Although there was not much cause for alarm in such 
parts, yet we had to exercise the greatest care in handling our cranky boat. Jacobson, 'the Pirate,' and Villegente could not swim a stroke. With the exception of Maite and myself the others were very poor swimmers. Freddy landed several times after game-birds, and fired ten or twelve shots in all, but he only secured two curassows. Perhaps nervousness or hunger had something to do with his bad shooting. Stopped at noon to cook one of the curassows Freddy had killed. By way of a change the meat was roasted on the glowing coals, but although I ate my full share I could not get over the sensation of emptiness from which I had been suffering during the last few days. I had read somewhere that the Kaffirs and other savage tribes use hunger-belts when pressed for food, so I wound a strong creeper several times round my waist. This certainly gave me a good deal of relief from the dull gnawing pain I experienced. River continued broad and deep. Landed once to try to get a shot at two red howlers I had noticed on a big tree, but was unsuccessful. Weather gloomy with strong gusts of wind and showers at intervals. Procured no game. At about three o'clock heard the distant roar of Achaba and half an hour afterwards passed through the first channel of these formidable rapids. It was time to look for a camping-place, so that the men might be able to build before nightfall some sort of covering against the threatening weather; so we moored the boat alongside of a thinly wooded island where were many fine Cattleyas in full bloom. We ate the curassow left over from the morning. Heavy rain, with lightning and thunder, all night.

May 10.- Suffered so much from fever during the night that I can scarcely stand this morning. Started 
without having eaten anything, not even wild fruit. Shot a large heron, the kind known by the natives as Garza morena. How glad we all were! If we get nothing else there is still something to eat. Three times we had to land and walk or rather crawl through the forest while the boat was being carefully let down by ropes. We have to be ever so cautious now. If anything should happen to our small dug-out we are lost. What hard work it was getting through the forest! Every two or three minutes we had to sit down and rest. Jacobson and Villegente appear to be even weaker than I, although they can eat more whenever we have food. Toiled on the whole afternoon until we staggered out on to the open beach where our camp had been pitched and where the boats had been launched after the portage. We threw ourselves on the ground and rested awhile. 'The Pirate' reminded me that $I$ had shot a venomous snake at this spot, quite close to him. It was only a short distance to our camping-place of March 30, and as we had then cut a good track through the forest when the boats were carried overland, we walked slowly across, leaving the boat securely moored to a tree to be dragged over on the following day. We hoped to be able to utilise the huts built on the up journey, but when we reached our old camping-place we found that it was flooded, the water almost reaching the forest growth, so we slung our hammocks under some detached trees fringing the beach. This part of Achaba is very picturesque. During the two days we had spent here some six weeks previously Jacobson had exposed several plates from which we expected fine results. The boats being hauled up through the rapids, our camp, the portage through the forest, the falls of Achaba, were all interesting subjects, but the plates lay buried in the 
sand at the rapids of Arichi. Again it rained all night, and when day dawned we found that the river had risen so much that there was nearly a foot of water under our hammocks.

May 11.-By ten o'clock the men had got the boat over the portage and we were ready to continue our journey. It would have been impossible to get the boat through this last part of the rapids with the whole of us in her, so 'the Pirate,' Maite, and myself took our places, paddle in hand, while the others started to walk over the hills so as to meet us lower down. We had to take Jacobson with us. Not only was he unable to move about, but if he attempted to stand he would topple over in the most ridiculous fashion. In spite of our sufferings and the gravity of our position, we could not help laughing at his strange performances. We crossed over to the right, and then lowered the boat for some distance along the bank, keeping close to the shore. In this manner we managed to get below the ledge which is at the head of the gorge forming the last channel of the rapids. When we had ascended the river this gorge had not given us much trouble, but we saw that it would be impossible to get the boat through the lower end of it in its flooded condition, as the last stretch was like a seething cauldron through which no boat could pass without being swamped. We noticed, however, that there was a narrow channel on the left, a few yards above where the big waves commenced. If we could reach this channel, it might be possible to get the boat through it. So far as we could judge from where we were this was our only chance. We paddled across with all our strength, starting at a point at the head of the gorge, yet so powerful was the current that we only just succeeded in maling the channel. A second 
more and we should have been dragged into the whirlpool. 'I'hen another difficulty arose. 'The Pirate' refused to shoot the small channel to the deep pool beyond, on the banks of which the others were awaiting us. He said that he preferred to walk over the hill, and that as both Maite and myself were good swimmers we were the proper persons to get the boat through. It was not so dangerous as it looked, although I took my clothes off in case we should get swamped. In a few seconds we joined Ramon and his party. 'The Pirate' came in about an hour after, having had to help Jacobson over the hill. Ramon had been lucky. He had taken my twelve-bore with him and had killed a large quail and a giant armadillo. ${ }^{1}$ During the whole of our trip this was the only one obtained, so that it must be rare enough on the banks of the Caura. Although it was only midday when we had breakfast, and we could have covered many miles in the course of the afternoon, the men refused to go any farther for the day. They said that it was necessary to smoke the armadillo, that there was plenty of meat, and that they meant to have a good feed and a thorough rest. And so many precious hours were wasted, while my thoughtless companions gorged and lazed. The thunders of Achaba did not allow us to get much sleep.

May 12.-The difference in the appearance of the river as it is now and as we had seen it a month and a half ago is most noticeable. Where our boat is tied was a large sloping tract of sand. Here our camp had been pitched and the men had built huts of which only the tops are now above water, so that the place has a desolate appearance. The men spent the early hours of the morning trying to finish what was left of the smoked 
armadillo. At last we managed to make a start. The river being easy of navigation we made a very good day's journey, passing our camping-places of March 26, 25, and 24. On each of the two last mentioned dates I had killed a tapir. How well the men remembered every detail of the two hunts! They dwelt with regret upon the remembrance of those days of feasting. When we stopped for the night we ate the last piece of the smoked armadillo, and as we killed nothing for the day, we shall have to start without food to-morrow morning.

May 13.-Shortly after starting Ramon shot a curassow and Freddy a penelope, so that we have something to eat. Passed through the Raudales Pauij, ${ }^{1}$ and stopped to cook on some open rocks below it. Have suffered so much from fever lately that Maite offered to prepare some Indian medicine for me. He went into the bush and returned with some bunches of a purplish fruit, somewhat larger than a coffee berry, but round. Between the skin and the seed there is a thin pulp of slightly sweetish taste. These bunches of fruit, which are the seeds of a sort of slender palm covered with spines, were boiled in water until it assumed the appearance of claret. The liquid was then, Maite said, fit for drinking. I was glad to try anything, so for the rest of the day I kept the pan containing it near to me in the boat, and dranli nothing else. Curiously enough the fever left me at night, but this may have been merely a coincidence. Passed a spot where a peculiar incident had occurred on the up journey: We had lecided to stop for cooking our midday meal, and chose a large slab of rock adjoining the steep densely wooded bank. No sooner had the boats 


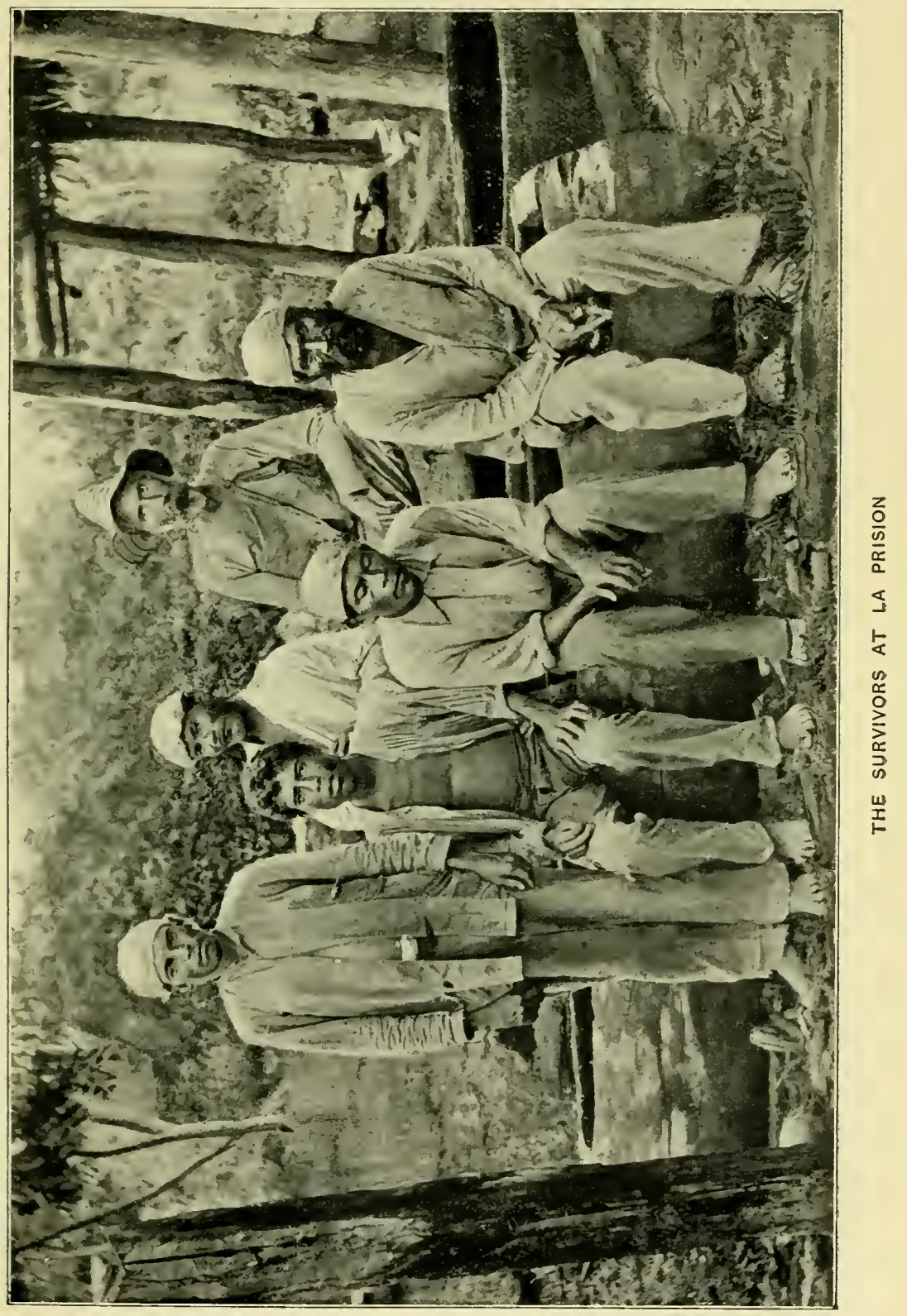



touched land than the dogs sprang on shore and bounded up the bank barking furiously. To our astonishment they came back howling and running as fast as they could, closely pursued by a large puma. So intent was he on the dogs that he took no notice of the boats, the smaller one of which he actually reached at the same moment that he struck Meoro, the large dog, tearing the skin off his ribs, and very nearly killing him. Pancho pluckily hit him over the head with his paddle, and it was only then that he found out his mistake and bolted back into the forest. The whole incident was the affair of a few seconds. None of us had time to get one of the guns out of the boat. Some of the men, headed by 'the Pirate' carrying my Winchester, started in pursuit, ably assisted by the dogs, who felt they had protection and were eager for revenge. They did not, however, succeed in coming up with the puma, who, after the shock he had received, had evidently made up his mind to put a good bit of country between the boats and himself.

We came across two kosoibo trees laden with fruit overhanging the river. Ramon climbed one and Laureano the other, and while they stayed above eating they shook the branches so that quantities of fruit fell into the water. We must have spent an hour under these trees. As it was getting late we encamped close by on a steep patch of sand, the only spot we could find fit for camping. To-day we passed the last of the several Indian ranchos seen on the journey. After dark, Laureano and Maite fished and one of them caught an Aymara, which they roasted. If we only had salt! I find any game or fish we get so loathsome devoid of salt or any condiment. What an awful thing it is to be craving for some necessary to which our systems have become accustomed! How 
I longed for salt and after salt for sugar! I feel I could swallow handfuls of both.

May 14.-If we kill nothing to-day we shall have to go without food. Started at daybreak and at about nine oclock reached Guayarapo. In our weak state the navigation of these dangerous rapids is most trying. In many places we have to get out and haul the boat over masses of rock or beds of shingle. Consequently we make but slow progress. At midday we rested for some time in the shade of a tree on one of the islands. Laureano tried to catch a fish off the rocks, but he had no luck. Cattleya superba is very abundant in these rapids and most of the plants were in full bloom, so that everywhere there were crimson blotches amongst the foliage. We worked the whole afternoon, yet when we stopped for the night we were not half-way through the rapids. The last two days have been fine ones with cool winds, an agreeable change from the almost continuous rains experienced since leaving Améha. Yet the blankets and hammocks are soaking wet from the water the boat ships at every moment. Maite was quite useless as a guide to-day. He appears to be losing his reason. Slept but little and suffered from violent headache and gnawing pains in the stomach.

May 15.-We got through Guayarapo by nine o'clock, after having twice filled with water; everything wet. Heard no curassows and we have not a morsel of anything to eat. Chewed some green wild guavas. Passed our sleeping-place of March 20, now flooded. Near to this spot are many curious rocks, mostly pinnacle-shaped. Up to midday nothing had been killed and it looked as if we were going to pass another day without food when we heard a pariji humming about 100 yards ahead of 
us. How we did take care not to make any noise, and how we tried by signs to impress Freddy, who landed to kill it, to be careful. After what seemed hours of waiting we heard a shot. Two of the men scrambled on shore, and when they returned a few moments after they had plucked the bird. We lighted a fire on the spot and in a short while nothing remained of the half-roasted bird but its bones. The river being flooded, the place was quite different in appearance to what it had been some two months ago. It was about five o'clock when we decided on stopping for the night. We had all landed, and those who had hammocks were slinging them between trees, when the dogs who had wandered into the forest began to bark furiously. Almost immediately a large tapir slunk through the bush and plunged into the river quite close to us. Before the men could pick up their paddles and loose the boat he had got half-way across. Ramon and Laureano, who went with me, being weak from hunger, were unable to gain on him, so that the two shots I fired just as he landed were long ones and I missed. The men insisted on following his track for some distance in the hope that he might have been wounded, but they returned without having seen him. This was the only tapir we had come across since the one killed the day we eft Améha.

May 16. - It rained heavily the greater part of the night and when day broke it was still pouring. We waited for some time to see if the weather would clear up, but no change taking place, we started. Maite, although he complained bitterly of cold and weakness, insisted on taking his place at the stern. He was terribly emaciated and his eyes had a fixed stare unlike anything $I$ had seen before. After we had gone 100 yards it was evident that 
he could not steer, so 'the Pirate' took his place, and we put him in a reclining position in the bottom of the boat. We were in an exceedingly difficult part of the river to navigate and twice we shipped water. Maite, who was singing catches of Indian songs and laughing wildly, was unable to direct 'the Pirate,' as he had become quite incoherent in his answers. I knew, however, that above all things it was necessary to avoid the channels on the right, which rush towards the big fall. After a while our old Indian guide ceased singing and laughing, and we thought that he had fallen asleep. All the time the rain poured on us in such torrents that the boat had to be baled out every quarter of an hour. At noon we reached one of the most intricate parts of the Caura, where the river spreads into a perfect network of channels before dividing to form the island over which is the portage. We went astray several times, but at last we reached the ledge of rock beyond which there is only one channel on the left. It was then we found out that Maite was dead. The whole of the afternoon was spent in dragging the boat across the rock, the men being so weak that they had to lie down from time to time. It was sunset when we reached our old camping-place of March 18. I shot a courlan ${ }^{1}$ with the Winchester rifle-one of two that had alighted on the rocks at some distance from us. It was boiled and divided up, and was the only bit of food we had tasted for seventy-two hours, with the exception of yesterday's pauji. The men said that it was too late to bury Maite, and that they were moreover too tired to dig a grave.

May 17.-The men scooped out a shallow pit in the sand and placed the corpse of our old Indian guide in it. 
We covered the grave with stones and hurried away from this ominous scene of death, which every one of us looked upon as a foreboding of our doom. On the up trip hours had been spent hauling the boats over the shallows; now we were borne rapidly through the channels by the swiftness of the current. As we neared our old camping-place, the remains of the ranchos we had built on the up journey came in sight, and this appeared to inspire the men with hope, for they shouted in chorus 'Para! Para!' It was 'The Sea!' 'The Sea!' of the Ten Thousand.

As soon as we landed the men rummaged about our old encampment and succeeded in finding a large yam we had left behind because it had the spot. It had kept remarkably well, having thrown out a few roots only. A fire was immediately lighted and the yam, half-boiled, was greedily devoured. The men recalled every detail of the tapir hunt on the up journey when at this spot they had feasted sumptuously, and they compared our starving condition with that time of plenty. We found a couple of empty tins at this place. In one of them $I$ put a letter addressed to Pedro Hospedales, and having tied it to the end of a long pole, planted the pole in an open place where the men could not fail to see it when they would reach Para. In my letter I tried to encourage them to hold out until help would reach them from La Prision.

The boat having been unloaded and securely moored to a tree, we walked to the hut in the middle of the island, the men carrying as many things as they could. I went on in front with the rifle, on the chance of killing some game. Jacobson and the taxidermist came next, and the men afterwards. I reached the hut just in time to avoid getting wet by a heavy shower which lasted for over an hour. The men dropped in one after another, soaked to 
the skin. We found at the rancho two bags of beans left behind because they were so old and hard that we thought them uneatable. We were delighted to get them, bad as they were, and the men soon had a potful simmering on the fire. We also found about ten pounds of rice, half a pound of tea, a small tin of lard, and a demijohn of sour molasses, but not an ounce of salt. For the first time for days we enjoyed the luxury of sweetened tea. In spite of all that we tried with the beans, they remained almost as hard and heavy as buckshot. I found them so tasteless without salt that I tried them mixed with molasses, but this was not an improvement. For dinner we had a little boiled rice and some tea. 'The Pirate' and Ramon, who had gone to the foot of the falls to see what they could pick up, returned with some yams. These fried with a little lard were the best food we had eaten for days. In spite of all my remonstrances the men sat up to a late hour eating beans and drinking molasses and water, so that by morning the greater part of the syrup had been consumed. It rained heavily from midnight until daybreak, the rain being accompanied by vivid flashes of lightning and deafening claps of thunder. The roar of the falls joined to the thunderstorm rendered sleep impossible.

May 18.-We went early to the spot where the heaviest of the boats had been left on the up journey, Ramon carrying the pulleys and rope. Although we tried our best we could not get the wheels of the pulleys to work; not only were they so water-logged as to be useless, but the rope in its sodden state could not be made to run. Where we were it would have been waste of time to have attempted to dry this gear, so I despatched two of the men to the foot of the falls to spread 
the ropes out on the rocks in the sun. I sent the rest back to bring the things we had left above yesterday. Jacobson, Villegente, and myself stayed at the rancho, wasting the little energy we still possessed in defending ourselves against the attacks of the ants and flies. When the men returned they brought but a small part of the articles we had left behind. They were surprised, they said, when they reached the spot where the boat was moored, to find that the river had risen several feet and had carried away the greater portion of our few remaining things. It was too late to think of walking to the foot of the falls, so we spent the few remaining hours of daylight in the rancho; the men brooding over the almost utter hopelessness of our position, I trying to devise some means by which we might get the boat to the river, should we not succeed in getting the pulleys to work.

Mag 19.-Started early and walked to the foot of the falls, the men carrying what remained of our things. On the way the dogs, having wandered from the path into the forest, barked furiously for some time; we then heard them howl, and when they returned they were terribly lacerated. They had probably been mauled by a puma or jaguar. After what appeared to me to be hours of painful tramping we reached the stretch of sand forming the banks of the pool below the falls. The long walk in my starved and weakened state had brought on a severe attack of fever, so that I was glad to throw myself on the soft white sand, where I lay panting until the paroxysm of the attack was over. How changed was Para! Was that raging whirlpool the placid pond with scarcely a ripple we had crossed on the up journey, when I had felt so disappointed with the falls? Could we hope to get through that seething cauldron without being swamped? 
The men, who had been dejected and sullen, were now in despair. They refused to try to get the pulleys to work, but retiring in a body to some distance from where I was lying they sat close to each other, evidently concocting some plan. It was almost night when Jacobson, who had lagged behind, crawled into camp. Villegente did not turn up. At about midnight my boy Freddy woke me and whispered that he had overheard the Venezuelans arranging to steal away at dawn, with the idea of abandoning us and walking to the settlement at Mura. I immediately went over to where they were sitting, for they had not gone to sleep, taking my rifle with me as a precaution. I reproached them for their ingratitude and cowardice, and then pointed out to them the utter impracticability of trying to get to Mura through the forest. After a good deal of talking I left them, satisfied that they would not attempt to walk to Mura.

May 20.-As it was a question of life and death to us that something should be done with the pulleys, and as the men did not know how to take them to pieces, I set about trying to get them into working condition myself. I succeeded in knocking the pin out and separating the wheels from the blocks, but it took me fully an hour to do this, as I was so weak that I had to stop repeatedly so as to lie down and rest. At this part of the proceedings the men got interested, and they willingly helped to scrape the wheels and the inner sides of the blocks. By eleven o'clock the hauling gear was in beautiful working order, and the men, as hopeful and enthusiastic as they had been dejected a few hours before, scrambled up the hill to make a first attempt at getting the boat down. A fortuitous coincidence had helped to buoy their spirits up. The river had fallen during the night some three feet, so that 
in the morning the whirlpool did not present that terrifying appearance which, more than anything else, had contributed to the men's mutinous and unreasoning behaviour.

The Caura is remarkable for the height to which its waters will rise in a few hours, to fall at times just as rapidly. After the departure of the men I lay down and rested during the afternoon. Villegente did not reach us to-day, so I sent Freddy with some boiled beans to meet him in the forest. When my boy returned he told me that the old taxidermist would not be able to overtake us until the morrow, as he could only crawl on his hands and knees. The men had refused to help him, probably because he had made himself exceedingly unpopular with them, although they gave as a reason that they wanted all their strength to get the boat to the water. They returned late, with the welcome news that they had hauled the boat forward a part of the way, and that they hoped, if things went well, we would be able to leave Para the day after to-morrow.

May 21.-Passed so bad a night that I can scarcely move to-day. We have some tea and about as much mouldy beans remaining as will last us until we leave Para to-morrow afternoon-that is, if we can succeed in doing so. I am subsisting almost entirely on strong unsweetened tea, all I can get down at a time of the mouldy beans without salt being a mouthful or two. Of this unpalatable food the men devour whole platefuls, yet they complain of hunger and weakness. When the men came in during the afternoon, they said that they expected to launch the boat at noon on the following day. Felt terribly hungry the whole night, and could think of nothing but food. Dull gnawing pains in the stomach. 
accompanied by fever and headache, rendered sleep impossible.

May 22.-When day broke I noted that the river had risen slightly during the night and appeared to be still rising. I had fixed upon a rock in the pool for my observations, and I could always tell whether the water was rising or falling. As the men did not appear to have noticed the change I did not enlighten them, and they started up the hill in a more cheerful spirit than they had shown for weeks. I fainted twice this morning. On both occasions Jacobson brought me round by pouring alcohol, a bottle of which had been left at the rancho, down my throat. At about noon, when we were beginning to despair of getting away, we were gladdened by the shouts of the men, who had got the dug-out to the brow of the steep declivity at the back of our camp. An hour afterwards we had the satisfaction of seeing the boat moored alongside of the sand at the edge of the pool. The men loaded her hastily with the few miserable things we still possessed, and we pushed off into the stream. The passage of the whirlpool was not without danger. Twice we shipped water and nearly got swamped, but when at last we issued from the whirling waters we knew that we were saved, and with joy in our hearts we allowed the boat to drift with the current until nightfall, the men being too spent to paddle. On the way the men had cut down some palm-trees growing at the water's edge, and had removed the tender shoots from the crown. These we ate when we stopped for the night on a rocky island in the middle of the stream.

May 23.- - Started early in a heavy shower of rain, feeling terribly weak, cold, and miserable. The men recalled the pleasant times we had had on the up journey, 
when we used to stop on the sandbanks in search of turtle-eggs. Jacobson reminded me of his omelettes. The sandbanks are now all covered, and the river is one stretch of brown water from shore to shore. At two o'clock we reached our old rancho opposite the mouth of the Nichare. This was a spot full of unpleasant memories. Here we had stopped for a day on the eve of our unfortunate expedition to the Nichare. Here on our return I had spent three days of suffering, and here Isidor, Vicente, and Laureano had left us at night, taking the small boat when they thought that I was too ill to move.

May 24.-Left very early. A terribly hot morning, without a breath of air. Suffered from such a severe attack of fever that the men stopped at midday so that I inight rest in the shade awhile. Many years before, Isidor had lived at this spot, but the clearing was at the time of our visit quite choked with second forest growth. The men cut their way through this and explored the place thoroughly. They were rewarded by finding some tubers resembling tanias, and a bunch of bananas. They also brought palm-seeds, which, when roasted, were not unlike pistachio-nuts in flavour. Altogether we fared better than we had done for days. We stopped for the night on the Isla Chaparro. One of the men caught a large fish, so that on the whole this was one of our luckiest days since the accident at Arichi.

May 25.-We reached Augustin's cane piece at ten o'clock in the morning. This is the last bit of cultivated ground at Mura. Although it would have taken only about a quarter of an hour more to reach the Indian settlement, the men insisted on landing in order to fill themselves up with cane-juice. They remained over an 
hour chewing canes, while Jacobson, Villegente, and myself were sweltering in the sun. When we reached the settlement none of the men were there. They had gone, Isidor's wife told us, on a hunting expedition, and she did not expect them to return until late. The women brought us cassava bread, yaraqué, and coffee, which was all they had. The provision gardens had suffered from the prolonged drought, they said, in consequence of which there were no bananas, yams, or sweet potatoes. They had been subsisting for weeks almost exclusively on cassava. They appeared to take but little interest in the story of our misfortunes, and they showed no feeling over Maite's death, although one of the women said she was his sister. What had happened was just what might happen to any Indian at any time. Why worry over the inevitable, why grieve over a being that was dead and gone?

On our departure I left word for Isidor and the others. to join us on the following day, so that the relief expedition might be arranged with all despatch. At one o'clock we paddled into the stream at La Prision. We tied our boat to a tree at the landing-place, and then we crawled up to Doña Antonia's house. We must have been a miserable-looking lot, for our kind-hearted hostess could hardly restrain herself from bursting into tears while she alternately hugged Jacobson and myself. All was bustle and excitement at the settlement, and we soon had such delicacies as soft-boiled eggs and fried bananas placed before us. The men gorged the whole afternoon, as a result of which they were sick for days after. 


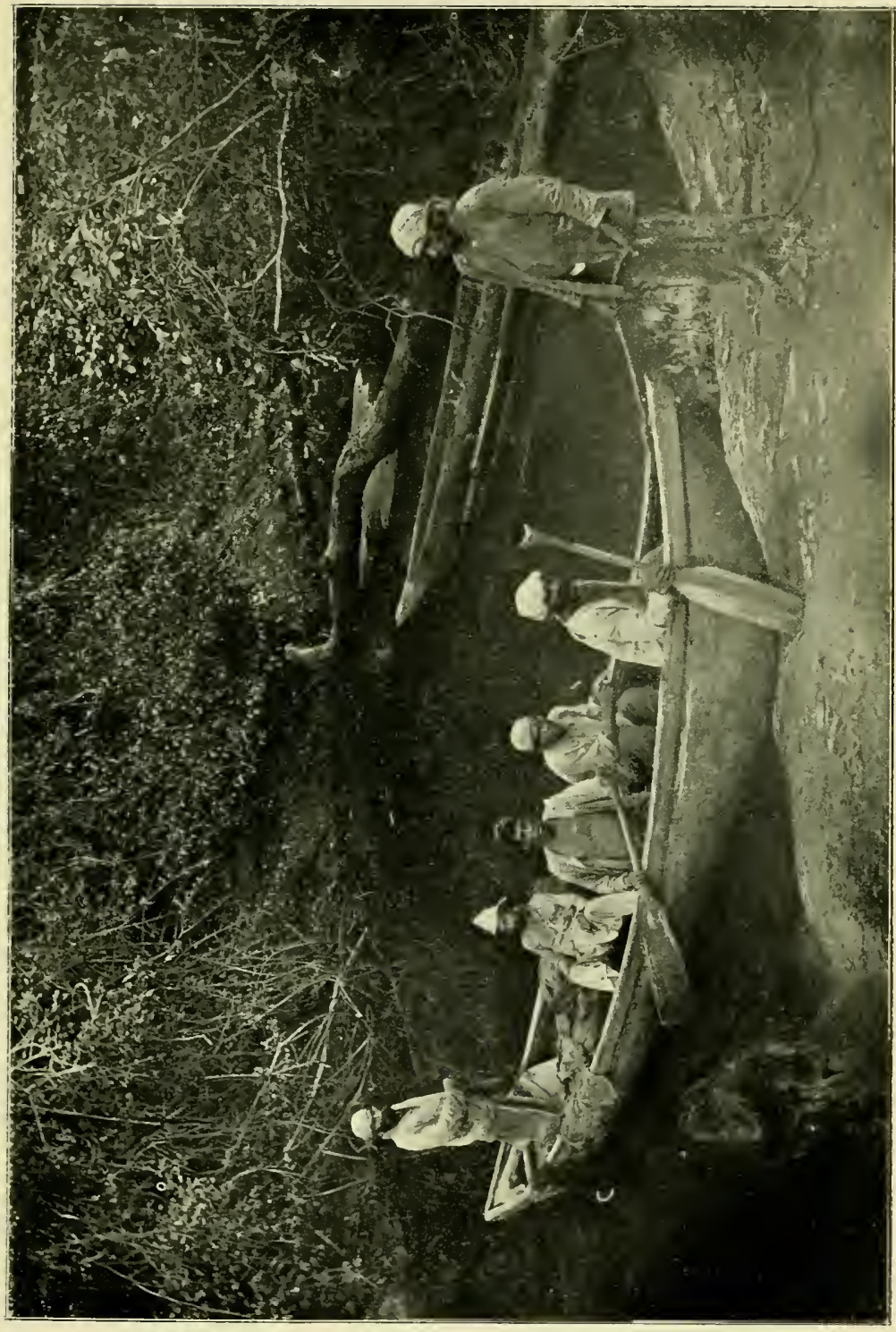

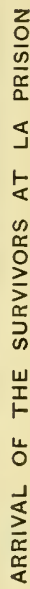





\section{CHAPTER XX}

Departure of the relief party-Juan Silva's wife-With the WaiomgomosCotton-spinning-A primitive dark-room-Orchid collecting-CassavaYaraqué-Basket-making-Return of the relief party-Canoe-building-Agriculture-Treatment of children-The blow-pipe-IsidorDeparture from La Prision-On the Orinoco again.

The first thing I had to think of was the relief party. Unfortunately Medina had gone to Puerto Antonio Liccioni for supplies and had taken several men with him, so that I experienced a good deal of difficulty in obtaining the hands I required. In Medina's absence Juan Saba was the chief man at the settlement, and he agreed to go as head of the relief expedition if I would give him a gun on his return. Having at last obtained the men required, my next difficulty was with regard to provisions and a small boat. The clearing at La Prision, like the settlement at Mura, had suffered severely from the long drought, and that was the reason why Medina had been forced to go to Puerto Antonio Liccioni for supplies. By sending to the settlements of Temblador and La Union, I succeeded in getting together sufficient yams, sweet potatoes, and rice for the trip, and at the latter place I also procured a small dug-out. For these things I had to pay three or four times their value; for the people, having realised that I was in urgent need of provisions, had agreed to make the most of the opportunity. I bought a steer from Juan Saba and it was slaughtered and the meat salted. Of the Indians only Isidor consented 
to accompany the expedition: the others said that as the rainy season had set in they were planting up their gardens and could not leave. On the afternoon of the third day of our arrival I had the satisfaction of seeing the relief party off. It was not a very sober lot of men I shook hands with, when I tried to impress upon them at the last moment the importance of the mission they were going upon. But I knew from long experience that it would have been useless to have attempted to prevent the peons from getting drunk on the day of their departure on a trip of several days. Their instructions were to get beyond the falls of Para if possible, and to do everything in their power to rescue those who had remained behind. It was only after they had left, that 'the Pirate' ventured to express an opinion on their chances of success. ' I do not like to meddle with what does not concern me,' he said, 'but I believe it is waste of time to have sent a boat to meet the men, because I am pretty certain that they have not followed the river. I did not care to tell you this before,' he continued, 'because it may be that after we separated they changed their minds; but Pancho told me privately the last night we spent together, that he had discussed the matter with the others and that they were thinking of leaving the river and striking through the forest in the direction of the Chawarro where the Camaracotas dwell.' I learnt in addition that it appeared to be Pancho's belief that the savannahs were not far from where we were at the time, and that it would be much easier to reach them than to get to La Prision by the river. This had been one of those occasions on which the men had made plans and kept their intentions secret from me. The same thing happened afterwards at Para, where my followers had deliberated as to the advisa- 


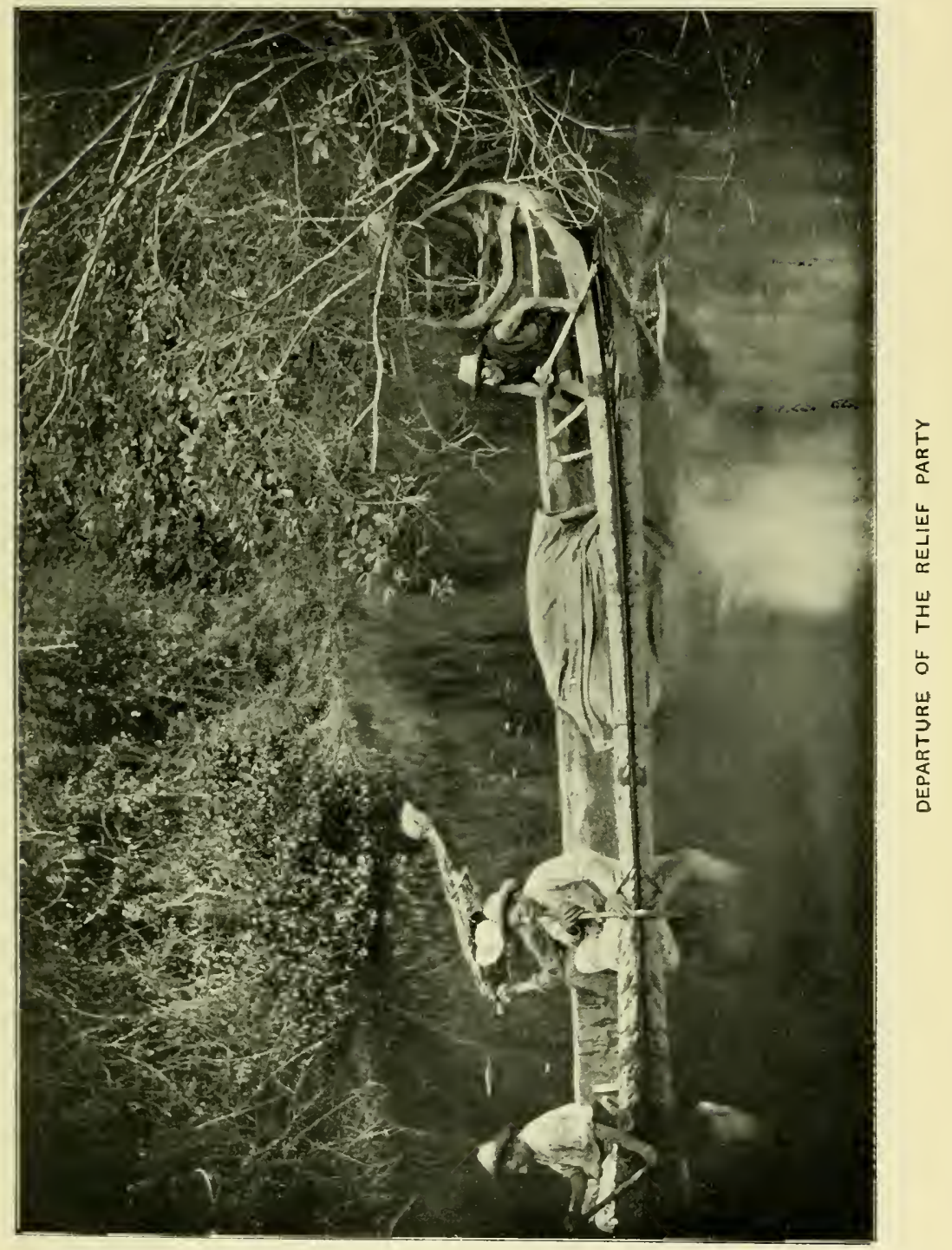



bility of abandoning the boat and walking through the forest to Mura. If Pancho and the others had really left the river in the hope of reaching the savannahs, I could not help thinking that we should never hear of them again. In any case there was no help for what had occurred: all we could do was to await the return of Juan Saba and his companions. On the day after their departure Juan Silva's wife came from Temblador. We were apprised of her arrival by her loud wailings, which she kept up for hours after reaching the house, Doña Antonia doing her best in the meantime to comfort her. Finally she quieted down sufficiently to discuss the business side of the question. Was poor Juan entitled to any balance in cash, and how much was it? Would I hand her over the amount if he did not come? I felt relieved. No woman who takes so sensible a view of the loss of a husband is ever going to die of a broken heart. I put her in possession of the facts and she became comparatively cheerful. I was glad of this, as some men who had been engaged cutting cedar in the forest were leaving in the afternoon for Puerto Antonio Liccioni, and I wished to take advantage of the opportunity to write letters to friends in Trinidad, to my wife and daughters in London, and to my agents Messrs. Hugh Low \& Co. It would have been impossible for me to have attended to any correspondence had Juan Silva's wife proved inconsolable. After all, the woodcutters did not leave until the following morning, so that I had ample time to write all my letters.

By June 1 Jacobson and I were well enough to walk about with ease, if not with energy. Singularly enough the men who had been ever so much stronger than both of us on the day of our arrival were all laid up. 
some of them having their limbs and faces quite swollen. They had made themselves ill by continuous gorging from the moment of our reaching the settlement.

As there was nothing to be done at La Prision, I decided to spend the time during which we should be waiting the return of the relief party with the Waiomgomos at Mura. There I would be able to collect Cattleya superba, observe the Indians at home, and take photographs of interesting subjects. We had the small hand-camera, which had luckily been left at La Prision when we went to Améha. On the morning of June 2 we packed all the things we required, intending to start in the afternoon, so as to spend the night at Mura and begin our work early on the following day. From noon to nightfall, however, it rained so heavily that we were forced to postpone our voyage until the following morning. We left at nine o'clock, reaching the site of the old settlement a couple of hours afterwards. I was quite surprised to meet here with a man from Trinidad, who recognised me the moment he saw me. He had come to Mura a couple of months before, he said, and had hit upon the old settlement, where there were already some cocoa-trees, as the best spot for a conuco or small plantation. He had cleared a part of the land and planted it in rice, which was then sprouting. The mango-trees left by the former settlers were laden with fruit and we bought a quantity for a few cents. By midday we reached the Indian clearing on the opposite shore and, having had our things landed and brought up to Vicente's house, where we intended to put up, I sent the men with the boat back to La Prision, keeping only Freddy Hospedales with us. When we arrived one of the Indian women was spinning cotton-twine for making 


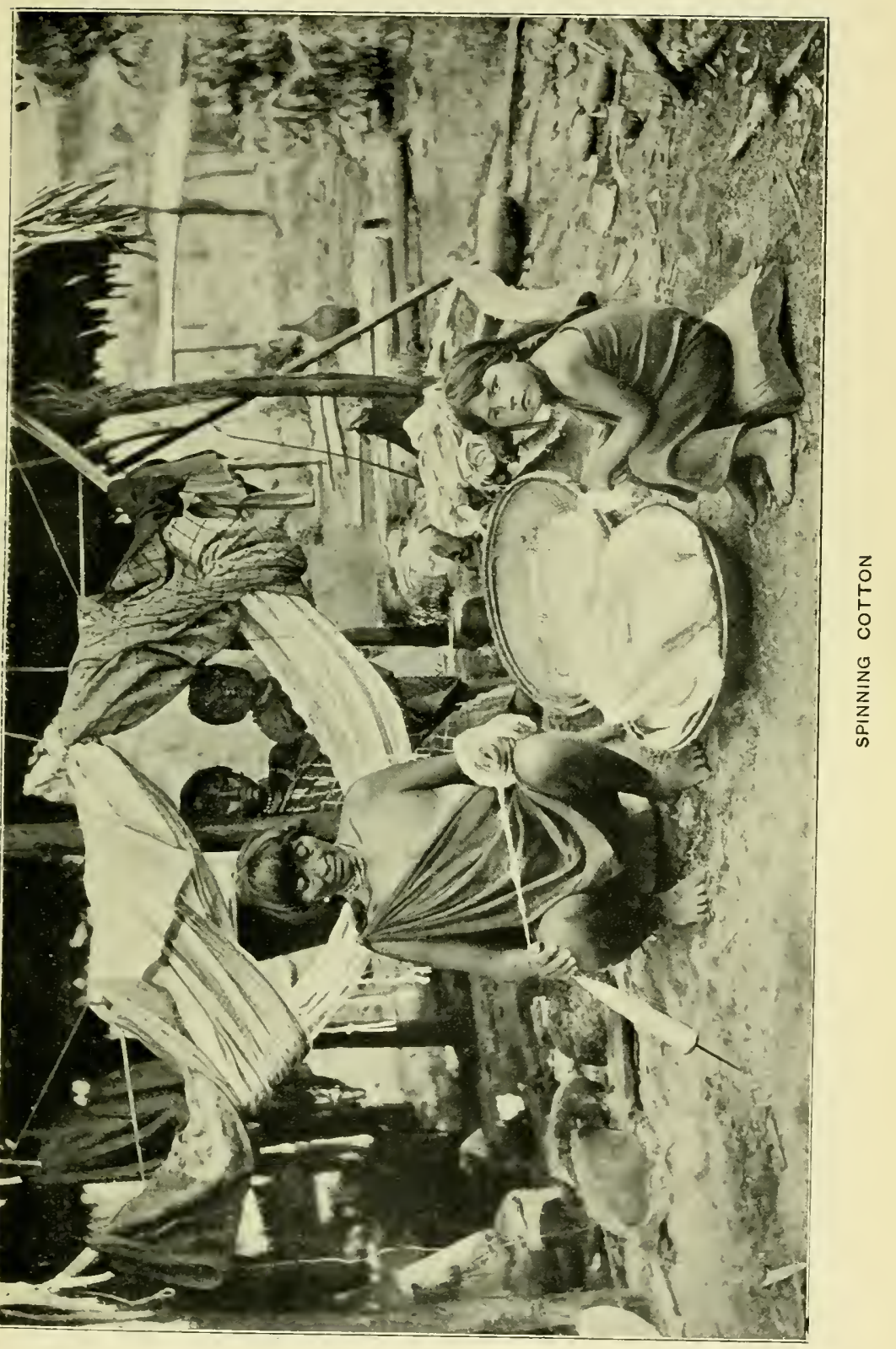



a hammock. We were able to observe the operation, which lasted a week and afforded Jacobson opportunities of taking photographs of the process at different times. The cotton having been freed from seeds is roughly pulled into loose bands, the ends of which are stuck to other similar bands by pinching them together so as to form a longer band. This is wound loosely round the wrist of the left arm and then the first part of the operation of spimning is performed. The spindles used are the simplest of simple affairs. A thin round stick made of hard wood, with a disc placed about three inches from one end, that is the whole apparatus. The woman squats on her haunches with one of these spindles on the right, and she wraps the cotton on it as fast as she has made it into a rough sort of twine by rubbing it between the palm of her hand and her thigh. When the spindle has got as much cotton as it will hold, its contents are twirled on to a second spindle, the woman in this case lying in her hammock with one end of the spindle, which she turns rapidly round with the finger and thumb, placed between two of her toes. By passing the cotton in this manner from spindle to spindle several times a thinner, stronger, and more regular thread is obtained, but for the making of hammocks two spinnings are usually considered sufficient. The cotton-twine is rolled up into a big ball, which is beaten from time to time with a little round club of hard wood. From long experience these people can tell by looking at a ball whether it contains sufficient twine to malie a hammock. Two poles are now planted in the mud-floor of the hut, at a distance of from five to six feet, and the actual making of the hammock is begun. The woman wallis round and round the poles with the big ball of cotton in her hands, and as she goes 
she unwinds the twine and draws it tightly and regularly from one pole to the other, until the desired width has been obtained. The cross-bars are then woven in and the hammock removed from the poles, after which the suspending lines are added and the work is complete.

On the day after our arrival I engaged Augustin and his two sons, with Isidor's boy, to build a dark-room for Jacobson, so that he might develop his plates from day to day. It was made entirely of palm-branches and the broad leaves of the wild banana, and was altogether'a very primitive affair, but it answered our purpose admirably, although Jacobson used to say every time I let him out, for the door could not be closed or opened from the inside, that he felt as if he had been rescued from the Black Hole of Calcutta. Having satisfied Jacobson's photographic requirements, I turned my attention to orchid collecting. For this purpose I employed Vicente, Augustin and his sons, and Isidor's boy. I had collected extensively in 1898 both at Mura and Piritu, so that I felt it would be difficult to get together on this occasion a quantity of fine plants. On my first visit, our collecting expedition had been an enjoyable picnic. When we went to Piritu, where we remained three weeks, Isidor had taken his whole family with him, including the dogs and poultry. We had cncamped on a lovely islet in the middle of the rapids and this we made the base of our operations. In the morning we would visit the various islands or explore the river's banks, the finding of large well-shaped masses of Cattleyas being to me a source of daily pleasure. Even the men after a time entered into the spirit of the enterprise and took a keen interest in obtaining fine plants. It was then the height of the dry season and the water 
tortoises were laying. In the afternoons we would visit the sandbanks in search of their eggs, or we would fish for Morocotos in the placid pools under the copaiba-trees, returning at sunset to our island home, where we would sit on the rocks within the ruddy circle of our camp-fire close to the whirling waters, while Isidor's wife served our dinner out to us.

Under what different circumstances was I collecting now, sick and disheartened!-anxiously awaiting the return of those sent to the rescue of the rest of our party, harassed by the continuous rains and depressed by the gloomy aspect of the sky and scenery. Although we worked hard we obtained but few plants. To make matters worse we were restricted, on account of the scarcity of fresh provisions, to a diet of cassava and tough salted meat. The cassava-plant was the only one that had not suffered much from the protracted drought, so that the women were engaged almost every day in preparing cakes and yaraqué for the use of the household, there being nothing else to eat at the settlement. The cassava-plant (Manihot utilissima) is of the same family as the tree ${ }^{1}$ that produces the rubber shipped from Brazil under the name of Ceara rubber. It is a woody plant, with large tubers possessing a bitter taste. In the raw state or when boiled only the juice of these tubers is highly poisonous, which is due to the presence of hydrocyanic acid. In Trinidad, where both the sweet ${ }^{2}$ and bitter cassava are grown, deaths occur occasionally through one root being mistaken for the other. It is a curious fact that the agouti (Dasyprocta aguti) can eat the poisonous root of the bitter Manihot with impunity. In fact, wherever therelare clearings planted with this tuber, 
it forms the staple food of this rodent. Hunters are always careful to remove every part of the intestines of the agouti, which they say are poisonous, and they take care to bury, or in any case to throw away, this dangerous delicacy so that their dogs may not be able to partake of it. Other curious instances of animals enjoying the privilege of being able to take certain poisons without evil effects are those of the goat and hemlock, the horse and aconite, and the rabbit and belladonna.

But to return to the manufacture of cassava-cakes. The women carry the tubers from the field to the house in deep baskets, by means of a broad band of bark passed over the head. After the contents of these baskets have been heaped into a pile on the ground, they sit around and peel the skin off the roots with knives. The roots having been peeled are washed thoroughly, after which they are grated into pulp. In the far-away districts the graters are of board into which sharp bits of stone have been cemented; but at Mura, where it is possible to obtain pieces of tin from the cans that have contained kerosene oil, the Indians make their graters, by driving a nail through the tin in the form of small squares. The tubers are rubbed up and down over the graters, placed in an inclined position in the carapace of a water tortoise. The pulp is then transferred to the squeezer, a long cylinder of wicker-work which hangs by the loop at the upper end from one of the beams of the house or from a post with a cross-bar planted in the ground outside. Through the loop at the lower end a pole is passed and to this heavy stones are attached, in addition to which the women and children sit on it, so as to apply as much pressure as possible to the cassava in the cylinder. The poisonous juice is by this means forced out through the 


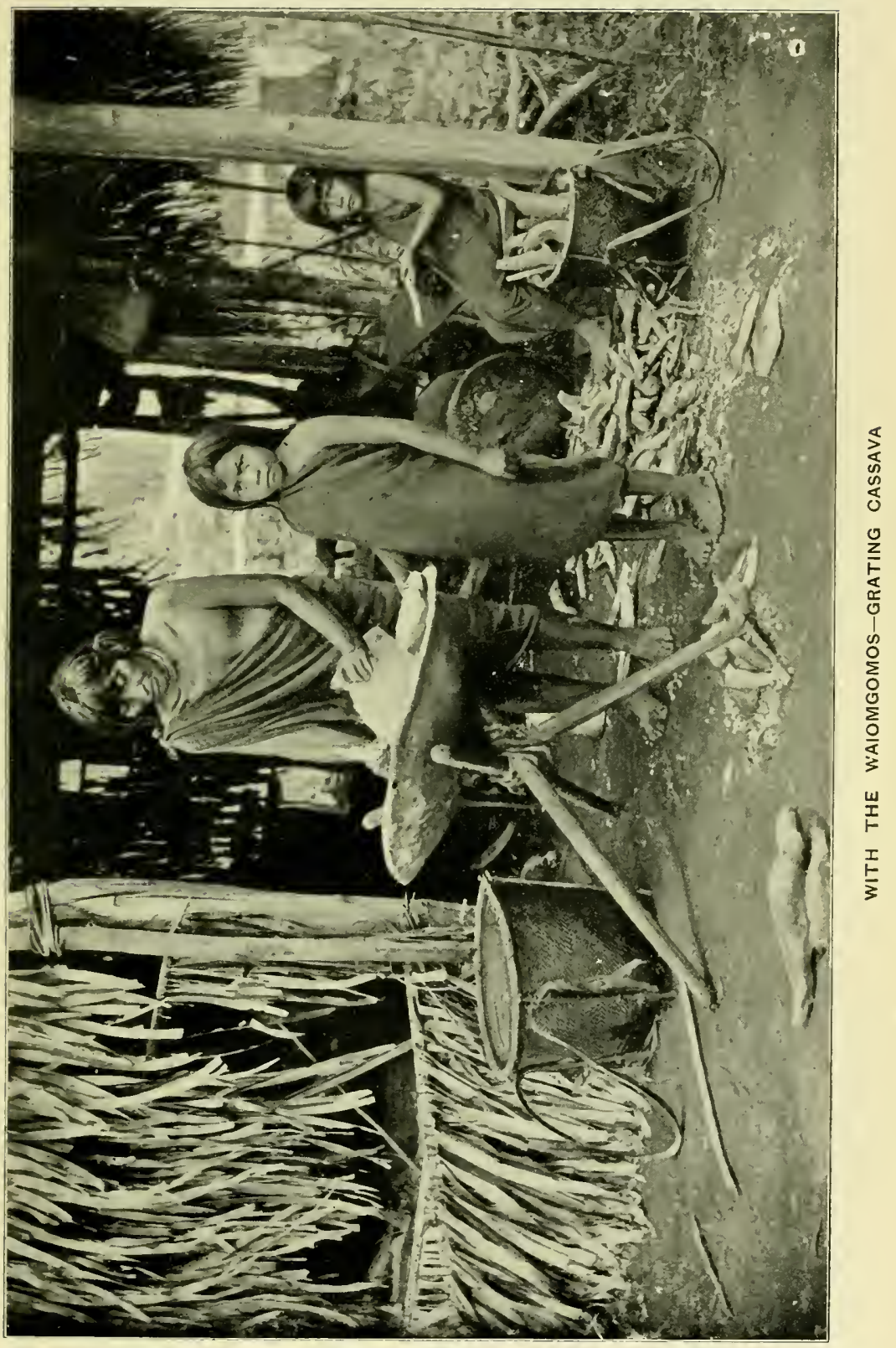



interstices of the squeezer and trickles along its sides to fall into some receptacle placed to receive it. It is from this juice that the thick black syrupy liquid known as cassareep is made. The dry cassava when taken out of the cylinder is in the form of big lumps. These are broken up and passed through a sieve, after which the coarse flour so obtained is spread in the form of a large thin circular cake on the baking plate. A woman with a fan in one hand and a knife in the other attends to this part of the operation, which is performed in a very short space of time. After the cakes have been baked on both sides they are thrown on the roof of the house to dry in the sun. From the odds and ends of the cakes and the coarser parts of its meal a fermented drink called yaraqué is prepared. Ordinarily this drink is made only in sufficient quantities every three or four days to meet the requirements of the household. Banana-leaves are placed on the ground in a corner of the hut, and upon these leaves the cassava, thoroughly damped with water, is spread in layers. On each layer a powder of a sage-green colour is sprinkled. This powder is called yaraquéro and is prepared from the leaves of a plant of the same name (Trema micrantha). The preparation of this powder is simple. The leaves having been dried on the large slab used for baking cassava, an operation which does not take long, are then reduced to powder by being rubbed between the hands. This powder is kept in well-stopped gourds, as there is a minute red ant that is very fond of it and will find it out wherever it may be hidden. The mass of damped cassava and yaraquéro is then covered over with the banana-leaves and allowed to ferment. At the end of two or three days the mass becomes slightly sour. In this state it is either eaten or drunk mixed with 
water and cane-juice. If allowed to ferment for more than three days it becomos intoxicating. Large quantities of yaraqué are consumed during the dances that form part of almost every/celebration among the Indians. On these occasions the stuff is prepared on a big scale, generally in dug-outs. The cane-juice used in sweetening the yaraque is obtained by pressing pieces of cane with a long pole let into the stump of a tree, the pole being used as a lever. Sometimes the juice is boiled until it thickens into a syrup, but as a rule it is used in the raw state.

The work in which the Indians excel is the making of baskets. At Mura all basket-work is made of the split stalks of a plant closely allied to that producing arrowroot. This plant is called tiritic and belongs to the order of the Scitamineæ. Its stem is arundinaceous, terminating in several rosulate leaves. It is this arundinaceous stem that is used in the manufacture of the baskets and sieves one sees in every Indian house. Quantities of these stems having been collected are split in the first place into four long strips by running two pieces of thin wood through them crosswise. Each strip is then split into two so that every stem produces eight long strips, which are ready for use after the pith adhering to them has been removed by pulling them along one of the finger nails. The baskets are made on frames and are of different sizes and shapes. There are shallow ones used for storing cotton, beads, and other ormaments, as well as the fish-hooks, lines, and arrow-heads used by the men in their fishing and hunting excursions. The Indians always carry their loads in a deep basket by means, as I have already said, of a broad band of pliable bark passed over the head. If they go on a long journey the cassava and 
bananas for the trip (with a small pot for cooking) are put at the bottom of the basket, the hammock being placed above. For carrying cassava, sweet potatoes, and even firewood to the huts these baskets are invariably used. Whenever we went out orchid collecting the Indians always brought their baskets with them for packing and carrying their plants.

On the afternoon of the 7th (June) at about three o'clock, Isidor's wife came running to the house in a state of great excitement, a rather unusual frame of mind for an Indian woman to be in. She said she had been standing on the rocks which command a good view of the rapids for a considerable distance, when she had seen for a moment what appeared to be a boat shoot across one of the narrow channels. We accompanied her back to the spot, but for some time we saw nothing but the boiling bubbling waters forcing their way through the rocky channels, and I was on the point of telling her she must have made a mistake when a boat came into sight in the distance. It was impossible to say how many persons were in it, but it did not appear overcrowded, which would have been the case had the relief party been successful in its mission. By degrees, as the boat came closer, we could distinguish its occupants: they were Juan Saba, Isidor, and the two men despatched ten days before. Evidently the expedition had failed. Isidor related how they had reached Para and had tried repeatedly but in vain to cross the whirlpool so as to get to the island. They had then attempted to scale the wall of rock on the right bank of the fall in order to reach the river above, but in this again they had failed. They had met with no sign of the men anywhere, so that they had come to the conclusion that it was useless to remain at 
Para and had returned. In reply to my suggestion that another attempt should be made to get beyond Para, they declared with one voice that any such attempt would be madness, and that they would not undertake it. Isidor added that he felt certain the men had not followed the river, as they would have reached the island had they done so, and he would have been able to see them from the opposite bank. Where were those poor men at the moment we were discussing their fate? Had they perished or were they still struggling through the forest in the hope of reaching some human habitation? In spite of the terrible misgivings $I$ felt regarding them, I determined to wait two or three weeks more on the chance of their reaching us.

On the day after Isidor's arrival Augustin informed me that he would not be able to continue to help me in my orchid collecting. He had promised to deliver by the middle of the month a curiara on which he had been working when I arrived, and if he did not attend to it daily he said he would not be able to meet his engagement. He took me to see his handiwork and detailed the process of making curiaras or dug-outs. Cedar and sassafras are the best timbers for making these boats; preferably the former, as it is lighter and more durable. A suitable tree having been selected is felled and the portion for the dug-out cut away. This is rounded and shaped into the form of a canoe, after which it is hollowed out. With a gimlet or a hot iron holes are bored in the shell so that the builder may be able to regulate its thickness as he proceeds. When the curiara is considered sufficiently hollowed out a fire is made throughout its whole length with sticks and logs of wood. Finally the glowing coals are removed and the dug-out forced 


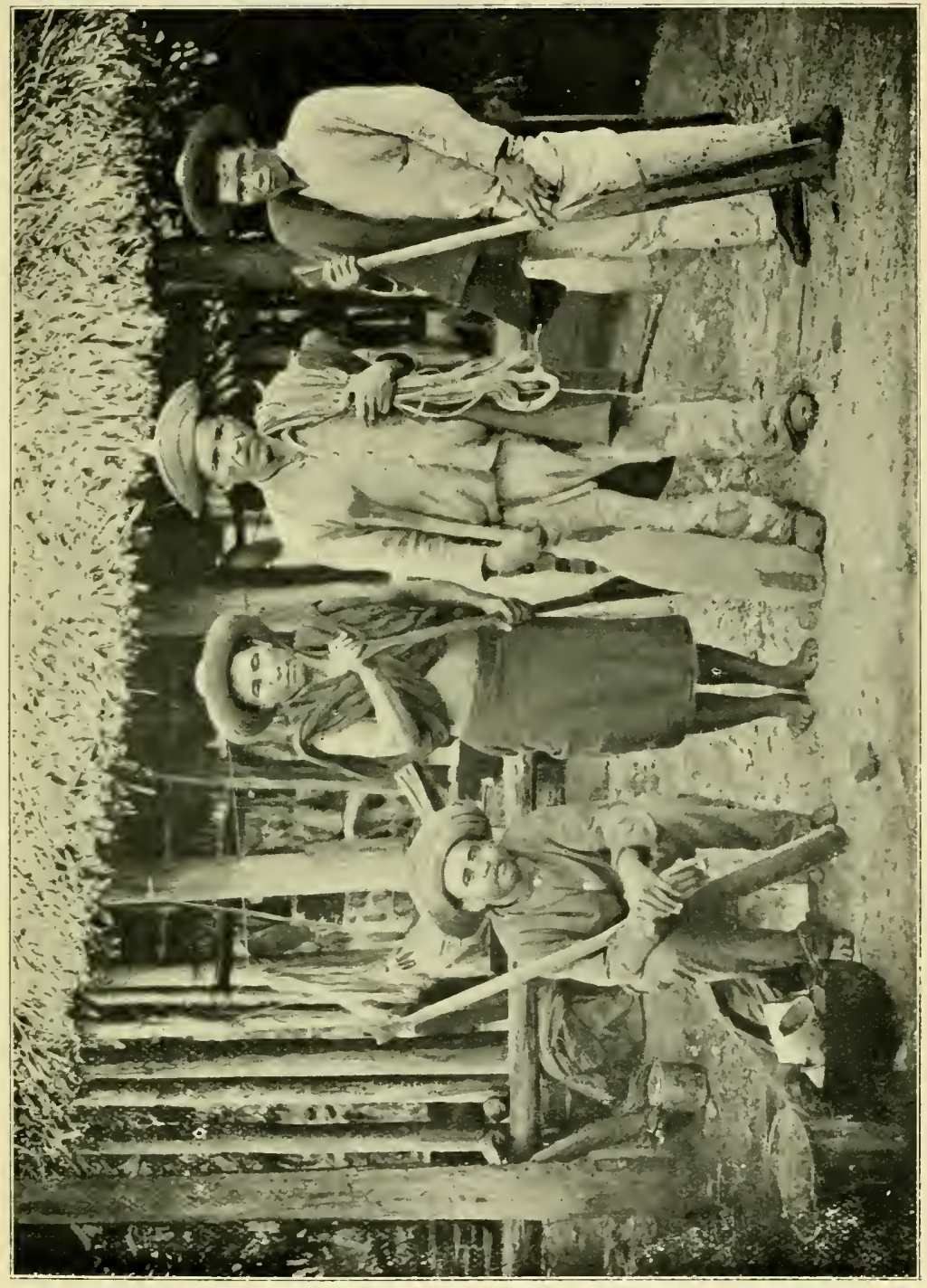



open while the wood is steaming hot. This is an operation requiring to be done rapidly yet carefully. Strong pieces of wood of different lengths having been placed between the sides of the dug-out in an oblique direction are struck by a heavy log until they are forced straight across. Then with longer pieces the operation is repeated until the boat is sufficiently opened out. Bars of hardwood are then let in and fixed firmly between the sides, and these, while they serve as seats, keep the canoe permanently open.

First operation after firing

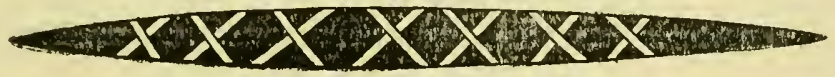

After the pieces of wood have been forced straight across

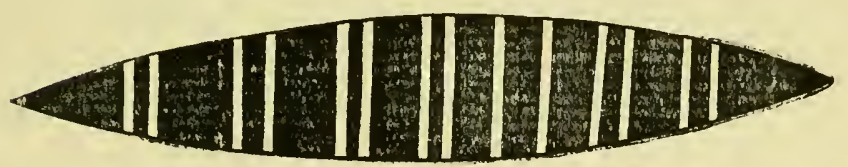

Method of Openisg Dug-odt

Isidor agreed to assist me in collecting orchids up to one or two o'clock every day: he devoted the rest of the afternoon to preparing the ground and planting his portion of the clearing. Among these Indians agriculture is carried on in the most primitive manner. When a family or several families have hit upon some spot in the forest as suitable for a clearing, the men proceed to cut down the trees and undergrowth, using axes for the former and their cutlasses for the latter. (I may mention here that any traveller visiting the Indian tribes of Guiana would do well to remember when bringing articles for barter with him that heavy axes or cutlasses are difficult 
to dispose of. I noticed that the Indians cannot bear to work with any but the lightest of implements. So far as axes are concerned they should not weigh more than three pounds.) The leaves and smaller branches of the felled trees and brushwood are allowed to wither and dry, after which they are set on fire, and this helps to clear the ground to a certain extent; but the trunks and larger branches, though they get more or less charred, are hard to burn, and they remain for years lying about with their bare and blackened stumps sticking up in the air, giving anything but a picturesque appearance to the clearing. With the first rains planting is begun. In the case of cassava, slips of the woody stem of the plant are inserted into holes around which the soil has been slightly loosened. For sowing grain, such as maize or rice, a pole sharpened at one end is used. From my hammock I often observed Isidor planting up the fields he had devoted to these two cereals. As he walked along he would plunge the pole he carried into the ground at regular intervals. $\mathrm{He}$ was followed by his son, who dropped a few seeds into each hole and then, as he passed, pressed the earth over them with one of his feet; and here I may mention that I was repeatedly struck by the dexterity these Indians display in the use of their lower limbs, employing them even for picking up any small article they may have dropped.

At Mura, besides cassava, maize, and rice, the Indians had planted sugar-cane, bananas, yains, pumplins, sweet potatoes, and a little cotton and tobacco, so that except on occasions of excessive drought they are well supplied with provisions. For animal food they depend entirely on hunting and fishing, and they almost always smoke whatever game or fish they may have obtained. 'They can eat enormous quantities of food when it happens to be 
plentiful. In fact, they have the disagreeable habit of getting up frequently during the night to eat, and thus it happens that anyone staying with Indians will be awakened repeatedly during the night by the movements of one or other of the party. This habit of gorging is acquired during early youth, when the children are allowed to eat as much as they can-that is, when food is abundant. Neither are the children interfered with much in other matters, nor are they punished in the way Europeans punish theirs. I do not remember ever having seen the Indians at Mura beat or in any way ill-treat their little ones. It may be this freedom in the method of his bringing up which makes the full-grown Indian impatient of any sort of control.

Of the numerous tribes which dwelt on the Caura and its neighbourhood, only the Waiomgomos have survived, and they also, although so far removed from civilisation, have, according to Isidor's accounts, decreased to an appalling extent within a comparatively short period. To-day the compound on the Merevari range does not contain more than fifty or sixty people, of whom about two-thirds are women. They are polygamous, some of the men having two or even three wives. In the few books I have read dealing with the Indians of Guiana, these people are referred to as Maionkongs. They call themselves, however, Waiomgomos. I was particularly careful to satisfy myself on this point, and I even mentioned the word Maionkong to Isidor as being the name by which his tribe was known abroad. He told me that the Indians through whom his tribe received such articles as knives and fish-hooks from British Guiana, spoke dialects so different from that of the Waiomgomos, that they would probably find it almost impossible to 
pronounce certain words correctly. To this must be added the difficulty attending the rendering of names from a language entirely different in structure to any European one, without taking into account the carelessness with which names and words are very often jotted down by travellers.

The Waiomgomos at Mura, who come in frequent contact with Venezuelans, have added something in the way of dress to what they were accustomed at the headwaters of the Merevari. The women are very fond of bright coloured cloth, a piece of which they wear tied over one shoulder so that it hangs down and covers the breasts. The men, while working, wear nothing but a strip of blue cloth passed between the legs and fastened to a string tied round the waist. To receive us they always dressed, if the wrapping of a piece of cloth around the body can be called dressing. A long strip of the same cloth is sometimes passed over the shoulders and under the arms in many folds. Both men and women paint their faces and bodies a brick red, using anatto, and the effect produced when they are well painted is pleasing. The Indians of the distant village on the Merevari do not use anatto, but a pigment obtained from a creeper unknown on the Lower Caura. The colour of this pigment is a bright scarlet, much brighter than that of the anatto. In many other matters the Indians of the small settlement of Mura have been forced by circumstances, not the least of which is their frequent intercourse with Venezuelans, to alter their mode of life, and to make changes in their implements and ornaments. Not being able, for instance, to obtain on the Lower Caura the reeds from which blowpipes are made, they have been obliged to abandon the use of these deadly weapons. Yet the blow-pipe is 
essentially a Waiomgomo arm, for the other tribes of distant parts of the Guianas get their supply of blowpipes or of the reeds for making them from the country near the sources of the Merevari, and these articles form the principal object of barter the Waiomgomos have to dispose of in their trade relations with other settlements.

The reeds are obtained from some mountains not far from the compound where Isidor was born. Humboldt, when he was at Esmeralda, witnessed the return of an expedition of Indians who had gone in search of reeds and other forest products. He says that when he and Bompland arrived at Esmeralda, the greater part of the Indians were returning from an excursion which they had made to the east beyond the Rio Padamo to gather juvias, or the fruit of the bertolettia, and the liana which yields the curare. One of the four canoes was filled in great part with that species of reeds (carices) of which blowpipes are made. They were from fifteen to seventeen feet in length, but without trace of any knot for the insertion of leaves or branches. They were quite straight, smooth externally, and perfectly cylindrical. These carices come from the foot of the mountains of Yumariquin and Guanaja, and are much sought after even beyond the Orinoco, by the name of reeds of Esmeralda. It will be observed by looking at a map of Venezuela that the Padamo, of which Humboldt speaks, rises either in or close to the country of the Waiomgomos; but, as I have said before, the courses of the rivers and positions of mountains as marked on the maps of this part of the world must be considered to be approximate only, no accurate survey work ever having been performed in these regions.

In the manufacture of blow-pipes the reeds are 
enclosed in the stems of a slender palm, and this again is an article of barter, for the particular palm used for this puxpose is not found in the country of the Waiomgomos. Isidor used to regret that he did not have a blow-pipe to show me how skilful he was in its use. He was always ready to speak of the distant compound whence he had come, and of his uncle Simon, who was the headman of the place, but I never succeeded in getting from him Simon's Indian name or the names of the others at the settlement. As I observed during my first visit all the Indians of Guiana appear to have the same objection to divulging to strangers the names by which they are known to their immediate relations; and this is why, I suppose, Isidor had bestowed on his uncle the name Simon, although the latter had never had any intercourse with Venezuelans. Im Thurn, in his work 'Among the Indians of Guiana' draws attention to the strong objection the Indians whom he visited have to the telling or using, even among themselves, of the name bestowed upon a child by the peaiman or medicine-man soon after birth, which is his proper name and is supposed to form part of himself.

Every evening Isidor would spend a couple of hours with me and speak about his people and the journeys he had made to the Paragua and Caroni, where the Camaracotas and Guaicas have settlements. He would dwell with delight on every detail of the yaraqué feasts and dances that took place on the return of one of these trading expeditions. He described the ornaments worn on these occasions-the gorgeous feather crowns, the strings of beads and peccary teeth, the bands of braided hair worn above and below the cali of the leg and around the arm under the arm-pits. Then he spoke of the music - the long 


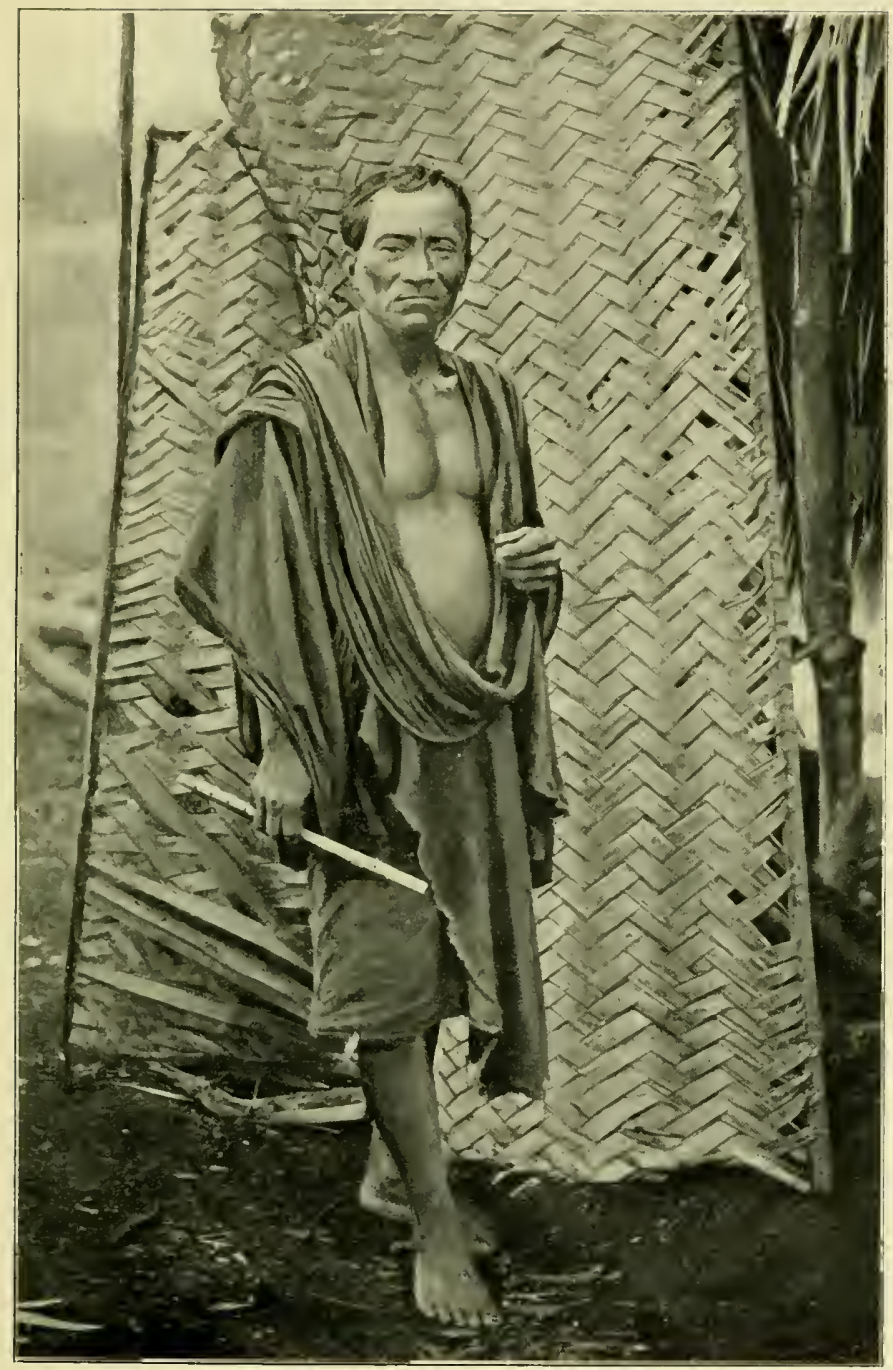

WITH THE WAIOMgOMOS-AUGUSTIN THE FLUTE PLAYER 

pipe, the big drum, the songs, and the dance. In spirit he was at his old home on the Merevari mountains and I was with him. Suddenly he would start up as if from a dream, and saying a curt 'good-night' would disappear into the darkness to tread his way between the spectral stumps to his hut in the centre of the clearing.

On the 10th (June) a boat came from La Prision with the news that Medina had returned from Puerto Antonio Liccioni and had brought supplies. To Jacobson and myself this was welcome news, as we were badly in need of a change of diet, and this decided me on returning to our headquarters, where we would be more comfortable than in the wretched hovel we occupied at Mura. On the morning of the 12th we left for La Prision, the Indians having promised to continue collecting orchids for four or five days more.

For several days after our return to La Prision I did scarcely any work, spending most of the time in my hammock, overpowered by a drowsiness I had never experienced before. Medina told me that this was the result of malaria and that it was called tiricia. It rained daily in torrents, flooding that part of the house where our hammocks were slung and causing us a good deal of discomfort. During the day the air swarmed with flies of different sizes, which got into our eyes and ejected a liquid producing a burning pain that lasted several minutes. With the setting of the sun we had to take refuge under our hammock-nets from the clouds of mosquitos that invaded the house; and even then, if we incautiously allowed any part of our bodies to touch the net, we would be attacked by them. On June 17 the Indians brought all the orchids they had got together. It would not be worth while, they said, to continue collecting, as plants were 
very scarce and the inclemency of the weather made the work doubly difficult. The plants were hung up on creepers under the eaves of the house, where the pigs and other animals could not get at them. Every day I prepared a few for packing by cutting away the old roots and bulbs, and we also made the crates to hold them. By the 25 th we were ready to depart, but I determined to wait until the end of the month in the vague hope of the men turning up. For the first time I ate Indian corn prepared in a fashion quite new to me. The corn having been soaked in water is dropped into boiling lard. The grains expand and burst and become white in colour, looking somewhat like jasmine buds. This was one of the few delicacies these people prepare. On June 29 at three o'clock in the afternoon we bade adieu to our hospitable hostess and the other inhabitants of La Prision, with the intention of passing the night at Temblador and reaching Puerto Antonio Liccioni on the following day. One of the boats was in such a terribly leaky condition that by the time we reached Temblador all the articles placed at the bottom were wet. We had to land everything, and again the greater part of a day was spent in repairing and caulking the thin rotten shell which bore us, so that we only left in the afternoon, arriving at Suapure after eight o'clock at night. On the following day we reached Puerto Antonio Liccioni. There we got some slight news of what had happened since we had been cut off from the civilised world eight months before. We learnt that Queen Victoria was dead, and the Boer war was still in progress. We read and re-read every bit of printed matter we could lay our hands on while we were awaiting the arrival of a large bongo which was to take us down the Orinoco to Ciudad-Bolivar. At last, on July 4, the 
anniversary of the declaration of American Independence, we shook the dirt, or rather the mud, of Puerto Antonio Liccioni from our feet and drifted slowly down with the current. It was our last night on the dark waters of the Caura. When we awoke on the following morning we were on the broad yellow expanse of the Orinoco. 


\section{CONCLUSION}

IT is now over eighteen months since the survivors of the expedition to Améha reached the settlement at La Prision. Since then nothing has been heard of the other members of this ill-fated expedition.

Although the photographs taken above Para, and the collections of birds, minerals, and plants from Améha were unfortunately lost, still the expedition cannot be said to have been a failure, considering that we now have a definite idea of the country traversed. The birds obtained on the Nichare and on the lower reaches of the Caura, which were sent to the Tring Museum, have been the subject, in conjunction with collections made by $\mathrm{Mr}$. Cherrie and Mr. Klages, of a work by Count Hans von Berlepsch and Dr. Ernst Hartert. This work will, I understand from Dr. Hartert, be included in vol. ix. of 'Novitates Zoologicæ.' I was fortunate enough to obtain some new species and a good many rare and interesting birds, and have thus been instrumental in adding something to our knowledge of the ornithology of this interesting region. If $I$ succeed in fulfilling the promise I have made myself of revisiting Améha and of reaching, if possible, the distant villages on the Parime mountains, I shall have satisfied the keenest desire of my life. 


\section{N D E X}

Acarv island, 100

Achaba mountain, 216

- rapids, 215-217, 266-269

Alligators, 94, 95, 136, 138, 205

Amazon river, 56, 184-187

Amazonas forest, 92

Améha, mountain, 28, 32, 139, 202, $205,246,249,258,260,272,273$,

286,304 ; expedition to, 221-.242

Andes mountains, 62 -64, 92, 236

André, Mrs., 285

- Misses, 285

Angostura, 55-56, 101. See also under Ciudad-Bolivar

Anson, Lord, 77

Ants, habits of, 122-123, 141, 147$151,203,261$

Ant-eaters, 144

Ant-thrushes, 149, 150, 204

Antonia, Doña, 121, 123, 140-145, 282,285

Apure river, 2, 62, 64, 94

'Apure' steamer, 104-106

Arauca river, 64,94

Arawa mountain, 28, 139, 218-224, $231,238,246,249,255$

- river, 221, 224, 252

Araya, 68-72

Argentina, 90-91

Arichi mountain, 28, 224, 225, 231, $238,246,249$

- rapids, 222, 251, 262, 268, 281

- river, 224, 246, 248, 251

Aripao village, 100, 101, 109-111

Armadillo, 269, 270

Arrichapa, 212

Arromaia, 6

Aruy river, 100

Asoque, Pedro (Chichî), 193, 195, $201,209,217,221,234,243,259$, 2.63. 264
Atahualpa, 3

Atures, 63

Augustin, 281, 288, 294

Ajaima narrows, 210

Aymara (fish,) 213, 218, 225, 254, 256,271

BALATA gum-tree, 66-67

Bald-headed cotinga, 233, 240

Bank of Venezuela, 68

Bark, uses of 127

Barquisimeto, 111

Barrancas, 13, 43, 44

Basket-making, 292

Battistini, Aurelio, 33, 34, 108

Bees, instincts of, 133-134

Beetles, 132

Belt's 'The Naturalist in Nicaragua,' 150-151

Benito (native paddler), 177

'Bird-carpenter.' See under Ville. gente, taxidermist

Bleekrod, Professor, 66

Blowpipes, 299, 300

Bohn's Classical Library, 130

'Bolivar' steamer, 13, 35-38

Bolivar, Simon, 49, $56 n, 60$; 'The Land of,' 62

Bompland, explorer, 100, 299

Branco river, 205

Brazil, 1, 40, 65, 109, 188, 205, 289

Briceno, General Barroeta, 58

Britton, Dr. L., 187

Bromelias, 27-29

Brown, Hon. Vincent, 36

Buenaventura, 169

Bullfighting, 83 seq

Bush-ticks, 30

Butterflies, 141-142

Byron, Lord, 84 
Catriao Company, 51-52

- Mines, 50, 108

Calliste paradisea, 190

Camaracotas tribe, 284, 300

Canaracuna river, 5

Cangrejo, 7, 9, 177, 178

Caño Guayapo, river, 9, 136

Canterbury, 77

Canuri, 6

Caracas, 61, 68, 95

Carenage, 38

Cariaco, gulf of, $70,74,114$

Caribbean Sea, 114

Caribs, 212

Caroni river, $1,2,53-54,100,101$, 300

Cassava plant, 289-292

Cassiquiare, 100

Castro, General, 61, 91, $95 n$

Cattle-rearing, 75, 102-103

Caulin, Father, 100

Caura, river, 1, 2, 7, 33, 178, 182-183, $195,201,208,209,269,274,303$, 304 ; source of, 4 ; tribes on the, $5-7$, 297-298; missionaries on the, 6 ; tonca-bean industry on the, 7-11; first visit to, $12 \mathrm{seq}$; rubber industry on the, 33-34; expedition up the, $90 \mathrm{seq}$; diseases prevalent on the, 110-111, 183; rise of the, $135,137,196,279$; limits of the, 210. See also under Merevari

'Caura' steamer, 13, 34, 91 seq. $106 \mathrm{seq}$

Cayenne, 34

Centurion, Governor Don Manuel, 101

Chawarro, 5, 284

Cherrie, Mrr., 304

'Chichi' (native). See under Asoque, Pedro

Christiansen, Brothers, 95

Cinco mil pesos channel, 195

Ciudad-Bolivar, 8-14, 33-35, 41, 44, $51-64,69,72-78,84,90,91,98$, $104,105,112,119,129,168,193$, 302

Ciudad de San Carlos village, 101, 171

Coche, 68

Cockfighting, $78 \mathrm{seq}$

' Cock of the Rock' bird, 201, 238

Cocoa-plantations, 171

Codazzi, quoted, 5

Colombia, 39, 63, 78 seq, 160, 169, 178,221
Columbia University, 187

Columbus, quoted, 40

Cormorants, 114-115

Coro, 68

Cosmer, Captain, 48

Cotton-spinning, 286-2s8

Creepers, 257; uses of, 125, 202, 253-254; dangers of, 153-154

Crespo, Mrs., 102

- President, 102-106

Croney, Corporal, 36

Cuchivero river, 2, 7

Cucurital, 118

Cumaná, 68, 69, 73, 74, 114, 160

Curassow rapids, 270

Curassows, 153-158, 210, 243, 252, $257-260,263,266$

Customs ; native blood-feuds, 4, 20 ; serenades and feast-days, 11,129 ; pack carrying, 15, 127-128, 202 203, 292-293; Indians assuming Spanish names, 15, 300 ; protection of snakes, 21 ; buildings in South America, 57, 125; dances, 71, 119, 292,300 ; modes of fishing, 75,97 , 135-136, 182-183, 205 ; cockfighting, $76 \mathrm{seq}$; bullfighting, $83 \mathrm{seq}$; tiiting the ring, 84 ; gambling, 41 , 85,129 ; life of the natives, 123$125,290 \mathrm{seq}$; hospitality, 120, 130 131 ; building ranchos, 195-196; painting the body, 298

Cuyuni river, 101

DAgUa river, 170

Darwin's 'Fertilisation of Orchids, $133 n$

de Aguila, Garcia, 48

de Grados, Geronimo, 45-48

'Delta,' steamer, 34, 39-41, 54, 56

Demerara, 34, 233

Derby, Earl of, 77

Dug-outs, 169-170, 294-295

EDWARD's 'Life of Sir Walter Ralegh,' 45

Egret ferthers (ospreys), 64-65, 95

El Callao, 53

El Muelle village, 114

El Potrero cattle-ranch, 93

Emecuni river, 5

Epifanio. See under Muñoz

Erewato river, 6, 19, 101, 199, $210-212,216$ 
Erinetta (Spaniard), 46-47

Esmeralda, 100, 211-212, 299

Esperanza, 16, 18, 152

Essequibo, 100

Ewaipanoma tribe, 6

Facdxdo (native), 165, 167, 176-178, 191,192

Fever, 49, 58-60, 183, 201, 204, 222, $241,254,258,266,270,277,280$

Fishing, modes of, 75, 97, 135-136, 182-183, 205

Fitt, Hon. George, 37

Fitzsimons, Mr., 36

Flies, 237, 256, 301

Fly-catchers, 153, 158-159, 174

Forests, submerged, 101

Foster, Sir M., $161 n$

Fowler, Hon. H. 36

Freddy. See under Hospedales

Freitas, 37

Frogs, 201-202

Gatacre, William, 77

' Gates of Hell, The,' 94, 98

Giblan, Sergeant-Major, 36

Gold-mining, 50-54

Grillet \& Co., 34

Guachee (native bean-collector), 16, 163

Guaharibos tribe, 92

Guaicas tribe, 300

Guanaja mountains, 299

Guaraguaraico village, 100

Guaraunos tribe, 42

Guarico, 101

Guaviare river, 92

Guayana la Vieja, 35

Guayarapo, 209, 210, 272

Guianas, 2, 4, 16, 41, 55-56, 92,

'Discovery of,' 5 ; dialects in the, 19-20; tribes of the, 297 ; 'Among the Indians of the,' 300

Gutta Percha and Rubber Manufacturing Co., 188

Guy (native), 15, 18, 20, 24, 29, 30

НАлмоскs, origin of, 40-41; manufacture of, 287-288

Hammond, 45

Hampden, John, 45

Hancox, Mr., 34-35

Hang-nests, 220
Flarragin, Mr., 36-37

Hartert, Dr. Ernst, 159, 304

Hawks, 145-146, 177, 201

Henderson, Jesse, 56-58

- Robert, 56-58

Hernandez, General, 102

'Hero ' steamer, 35

Heron, 106, 267

Hilaria mountains, $136 n$

Hornets, 140-141

Hospedales, Freddy, 173, 193, 195, $234,259-266,270,273,278,279$, 286

- Pedro, 159, 174, 177, 193, 195. $201,209,217,221,233,234,264$, 275

Humboldt, explorer, 4, 69, 100, 171, 211,299

Humming-birds, 153, 209

\section{IBIs, 217-218}

Iguana (reptile), 228-229

Indian corn, cakes, 123

- boiled, 302

Inga bush, 261

Insects, instincts of, 132-134; influence of a bright light on, 219 , 226-227

Isidor (Indian), 15-32, 157, 169, $172,175,180-183,190,191,212$, $281-283,293-300$; wife of, 282 , 289,298 ; son of, 288

Isla Chaparro, 281

- Larga, 176

Isle of Palms, 260

Iwararaqueri tribe, 6

JACOBSON, Mr., 39, 44, 119-123, 138 . $139,164,168,177,190,195,200$, $203-204,217,220,222,225,234$, $238,240,245-257,261-269,275-$ 301

Jaguars, 19, 161, 175, 181, 197, 223, 277

'John of Morocco,' 46

Journal Soc. Arts, $66 n$

Juan Griego, 69

Juana (Indian woman), 165, 168, 185

Keтmis, - , 45, 47, 49

Klages, Mr., 112, 304

Knevitt, 45 
Koro-koro (ibis), 217-218

Kosoibo-trees, 258, 260, 271

' La Aurora ' cattle-ranch, 102-106

La Ceyra island, 48

La Guavia, 69

La Plata river, 56

La Prision, 7, 9, 14-21, 31-32, $120-172,177,183,187-193,201$, $204,247,252,264,275,282-286$, 301-304

La Raya rapids, 180-183

La Union, 283

Laja Conchera, 163

- de los Perros, 16, 163

- Grande, 17, 31, 163

- Los Gallitos, 164

Laureano, Don, 71

Leon, General Perez, 38

Liccioni, Don Antonio, 108

Longacre, Mr. Orleans, 39, 119, 121, $123,168,177,178,184,187,190$, 193-194

Los Castillos, 44, 49, 58

Low, Hugh \& Co., 285

Lowther, Mr., 77

Lucy, Sergeant, 36

Macareo channel, 42,61

Madeira river, 56

Madrid, 65, 84

Maipures, 63

Maite (Indian guide), 15, 18, 19, 26, $30,166,169,175-180,191-243$, $250-273,282,300$; death of, 274

Maivi river, 262-263

Manapiari river, 211

Manon, city of, 3

Manufactures, \&c.: tonca-bean industry, 7-11, 14, 104, 110, 119, $129,152,163,176$; hammock making, 40-41, 287-288; gold-mining, 50-54; egret-feather industry, $64-65,95$; saltpans, $68-72$; fishing, 75, 97, 135-136, 182-183, 205 ; salted beef, $90-91$; alligator-skin industry, 94-96; cattle rearing, 75, 102-103 ; cheese-making, 103104 ; rice cultivation, 108,147 ; sugar, 122, 126-127; uses of creepers and bark, $125,127,202$, 253-254; rum, 129-130 ; сосоаplantations, 171

Mapire, 98, 99, 117
Maquiritares tribe, 92

Maracaibo, 74

Maravaca, 92

Margarita island, 41, 114

Maripa village, 14, 105-112

Mateo. See under Ramirez

Mato river, 113, 115

Medina, Jose Gregorio, 124-130, $168,169,172,193-194,283,301$

Meoro (dog), 244, 271

Merevari mountains, 5, 28, 205, 212, 297,301

- river, 4, 5, 139, 210, 216, 222-227, $231,238,240,257,298-9$. See also under Caura

Merida mountains, 92

Meta river, 2, 62

Mexico, 95

Monkeys, 160-161, 240 ; roasted, 259

Monos, 38

Montenegro, Pancho (cook), 169, $173,175,193,195,200-201,251$, 256-264, 284-285

Monteverde's compound, 119

Montezuma, 3

More, Sir Thomas, 151

Morocoto fishing, 182-183, 205, 289

Moths, 132, 139, 226

Mucurapo, 37

Muñoz, Epifanio, 195, 213, 223, 241, $245,263-264$

Mura rapids, 5, 7, 9, 32-33, 101-102 $121,138,165-167,170-178,182$, $195,205,209,278,281-301$

Murphy, John, 188

Muscivora coronata, 158

'Nicarag CA, The Naturalist in,' 150

Nichare river, $6,7,13,33,195-196$ $201,281,304$; expedition to the, 165-192

Night-jars, 143-144

'Novitates Zoologicae,' 159, 190 , 304

Nutall, Dr., 160-161 n

'Nutrias' steamer, 35

Orcuids, 162-163, 172, 201, 210, 266, 272,295 ; 'Fertilisation of,' 133 134

Orchid-hunting, $14,32-33,286,288$, 293-294, 301-302

Orinoco river, $1-7,35,43-44,50-73$, $92-99,106,108,117,129,138,166$, $182,302-303$ 
Orinoco delta, 42,44

- Lower, 52, 212

- Upper, 12, 62-63, 212

- Shipping and Trading Co., 34, 62

Orinocoponi tribe, 6

Ospreys (egret-feathers), 64-65, 95

Otters, 183

Owls, 153

Pacararsia mountains, 4, 5, 19, 13

Padamo river, 211-212, 299

Paisley, Dr. C. B., 36

Palm-trees, 75, 131, 261, 280

Palomeque, Diego, 46-48

Panama, 143, 146, 229, 262

Pancho (cook). See under Montenegro

Pará, 7, 65

Para falls, 6, 101-102, 139, 179, 193_ $197,202,205,214,215,224,242$, $250,255-258,262,264,275-281$, 284, 293-294, 304 ; described, 198 199

Para rubber, 65, 185, 188. See also under Rubber

Paragua river, 300

Paria, gulf of, 70

Parime, lake of, 3

- mountains, 1, 4, 16, 91, 300, 304

Paris, 52

Parrots, habits of, 8,174

Paru falls, 101-102

Peccaries, 134, 194

Pedro. See under Asoque and Hospedales

Penelopes, 217, 220, 257-260

Pepys, Samuel, 77

Piaroas tribe, 28, 92, 113

Pio (Indian paddler), 168, 177, 185

'Pirate, the.' See under Urbana, Luis

Piritu rapids, 9, 32, 102, 104, 176, $178,192,205,209,288$

Pizarro, 2

Plessington, John, 45-46

Point Araya, 45

Poisonous plants, 2S9-290

Port of Spain, 12, 34-37, 40, 56, 97, $144,166,174,226$

Pozo Bravo, 180, 183, 189-192

Puerto Antonio Liccioni, 106-108, $112-113,117,130,136 n, 165,168$, 193-194, 283, 285, 301-303

Puerto Cabello, 69
Pulleyn's 'Etymological Compend,' 40

Puma, 271, 277

QUELCH-McCoNNelL expeditions, 232 Quito plateau, 3

Ralear, George, 47

- Sir Walter, 3, 14, 49, 53 ; "The Discovery of Guiana,' 5 ; 'Life of,' 45

- Walter (the younger), 45-48

Ramirez, Mateo, 195, 241, 252-256, 263-264

- Ramon, 193, 195, 204, 250-256, $263-265,269-273,276$

Raudales Pauji, 270

Reid, Capt. Mayne, 96

Rice, cultivation of, 108, 147

Rice-bird, 145-147

Richard, J. B., 11-32, 183-184

Rio Negro, 56, 165, 169

Rivas, General, 105

Rock, Sergeant, 36

Rodriguez, Laureano, 195, 264, 265, $271-273,281$

Roraima mountain, 232

Roseliano, 119

Rubber industry, 33-34, 65-67, 184189, 289

Rum, manufacture of, 129-130

SABA, Juan, 283, 285, 293

St. Thomas village, $46-49,55$

Salt, manfacture of, 68-72

Salt beef, preparation of, $90-91$

San Felix, 13, 44, 50, 53-54

San Fernando, 97, 144

San Isidro, 102, 106

San Luis mission, 101

San Pedro, village, 100-101, 199

Sandfly, 108

Sarare, $1 \mathrm{II}$

Sefton, Lord, 77

Serrania de Mato, 8, 28, 113

- de Parime, 1

Seville, 84

Shelton, Sergeant, 36

Sierra Nevada, 237

Silva, Juan, 195, 259, 264, 285 ; wife of, 285

Simon, Father, 49

Simon (native), 300

Sipapo river, 2 
Slavery, 109

Small, Dr. John K., 187-188

Smuggling salt, $68,72-73$

Snakes, 160

Snake-bite, 252 seq

Société du Haut Orénoque, 12

Soledad, 55

'Spectator' quoted, 232

Spence's 'The Land of Bolivar,' 62

Suapure river, 2

- station, 7, 9, 14, 104-108, 113, 302

Sugar-industry, 122, 126-127

Sun-bitterns, 217-218

Suraima, 218, 260

Sylvestre (Indian), 15-20, 23, 26, 300

Taeniotriccus Andrei, 159 n

Taparitos tribe, $6,7,191$

Tapirs, 134, 172-173, 181-182, 205$207,210,213-215,223,227-228$, $244-246,260,270,273,275$

Temblador, 7, 9, 91, 104-105, 115$120,171,189,283,285,302$

Terns, 209

Themistocles, 77-78

Thurn's 'Among the Indians of Guiana,' 300

Tiger stories, 175

Tinamus, 155-156, 240

Tocantins river, 56

Tonca-bean industry, 7-11, 14, 104, $110,119,129,152,163,176$

Topiawari (native chief), 6

Torno, 94

Torquemada's 'De la Monarquia Indiana,' $65 n$

Tribes, extinct, 5, 14, 139, 297

Tring Museum, 304

Trinidad, 10, 13, 21, 33-34, 51-52, 61-62, 72, 75, 91, 97, 131, 143-145, $153,166-168,174-175,190,226$, 285,289

Tucumay, 146

Turagua mountain, $8,13,14,21$, $23-32,152,202$

Turban, Raoul (taxidermist), 15, 24, 29,30
Urbaxa, Luis ('the Pirate'), 135, $169,175,193-195,204,206,213$, $227,244,248-250,255,264-271$, $274,276,284$

Urbani village, 100

Uriutia, General, 37

\section{VANILLA-VINE, 172}

Venezuela, 1, 8, 12, 21, 38-44, 56, $61,64,66,77,90,93,109,124$ seq ; risings in, $34,63,95,105$; export and import duties of, 67-68; salt industry in, 68-70; diet in, 7374 ; leprosy in, 74; cockfighting, $78 \mathrm{seq}$; bullfighting, $83 \mathrm{scq}$; gambling in, $85 \mathrm{scq}$; maps of, 1-2, 299

Ventuari river, 1, 2, 101, 211, 212

Vicente (Indian), 169, 175, 190-192, $281,286,288$

Villegente, Mr. ('the Bird-carpenter'), taxidermist, 39, 190, 195, 234-235, 256-257, 264-267, 275279, 282

Von Berlepsch, Count Hans, 304

Vultures, 174

Waromoonos tribe, $5,6,16,165$, $191,212,233.286,297-300$

Water-snakes, 178

Water-tortoises, 193, 196-197, 288290

Water-vine, 27

West India Islands, 56, 66, 109

Wild-duck shooting, 93-94, 107

YAPECUNA river, 5

Yaraqué, 175; preparation of, 291292

York, 77

- Dean of, 77

Yumariguin mountains, 299

Yuruari mines, 41, 50

ZaxioRs, 111 


\section{RURAL ENGLAND.}

'Books unsurpassed in power of observation and sympathy with natural objects by anything that has appeared since the days of Gilbert White.'-D $\triangle \mathrm{ILY}$ NEWS.

\section{WORKS BY THE LATE RICHARD JEFFERIES.}

\section{THE GAMEKEEPER AT HOME; or, Sketches of Natural History} and Rural Life. With Illustrations. Crowa 8 vo. $5 s$.

'Delightful sketches. The lover of the country can hardly fail to be fascinated wherever he may happen to open the prges. It is a hook to read and keep for refereuce, and should be on the sheives of every coutry gentleman's library.'-SATURDAY REVIEW.

ROUND ABOUT A GREAT ESTATE. Crown 8vo. $5 s$.

'To read a book of bis is really like taking a trip into some remote part of the country where the surroundings of life remain very much what they were thirty or forty years ago. Mr. Jefferios has made up a very pleasant volume.'-GLOBE.

\section{WILD LIFE IN A SOUTHERN COUNTY. Crown 8vo. $6 s$.}

"A volumg which is worthy of a place beside White's "Selborne." In closeness of observation, in power of giving a picture far beyond the power of a mere word-painter, he is the equal of the Selborne rector-perhaps bis superior.'-ATHEN ÆUU.

\section{THE AMATEUR POACHER. Crown 8vo. 5 s.}

We bave rarely met with a book in which so much that is entertaining is combined with matter of real practical worth.'-GRAPHIC.

HODGE AND HIS MASTERS. Crown 8vo. $7 s .6 d$.

'The one great charm of Mr. Jefferies' writings may be summed up in the single word, "graphio." "-STANDARD.

WOODLAND, MOOR, AND STREAM; being the Notes of a Naturalist. Edited by J. A. Owes. Third Edition. Crown $8 v 0.5 s$.

' The book is capitally written, full of good stories, and thoroughly commendable.'-ATHEN $\$$ Uar.

FOREST TITHES, and other Studies from Nature. By the Author of 'Woodland, Moor, and Stream,' \&c. Edited by J. A. OWEn. Crown 8vo. 5s.

'Full of the spirit of the South vonntry, and as we read it we seem to hear again the claok of the millwheel, the cry of the waterfowl, and the splash of fish.'-SPECTAToB.

\section{ALL THE YEAR WITH NATURE. By P. Anderson Graham.} Crown 8 ro. $5 s$.

' Of the 28 papers composing the volume there is not one which does not brim over with love of Nature, observation of her by-paths aud power of sympathetic expression.'-OBsERVER.

A YEAR IN THE FIELDS. Selections from the Writings of JoHN Buнволgнs. With lllustrations from Photographs by Clifton Joнnson. Crown 8то. 68.

'Fresh and graphic, instinct with country sights, scents and sounds, - LAND AND WATER.

POT-POURRI FROM A SURREY GARDEN. By Mrs. C. W.

Earle. With an Appeadix by Lady Oonstance LYTTON. 26ta Edition. Crown 8vo. 7s. 6d.

Dеяn HoLE, in an article upon the work in the ' Nineteenth Century,' says: 'There is not time for further enjoyment of this sweet, spicy, "Pot-Pourri," no space for further extracts from this clever and comprehensive book ; only for two more earnest words to the reader-Buy it.'

By the same Author.

\section{MORE POT-POURRI FROM A SURREY GARDEN. FIFTH Im-}

PREsEION. Large crown 8vo. 7s. 6 d.

'This second volume has all the charm of the first. It is just the friendly chat of a lady who has not only read bo $\mathrm{ks}$, but knows all about her kitcheu, and, if possible, more about the garden she loves. On e'sch, sound, useful information is pleasantly conveyed.'-PuNCH.

A THIRD POT-POURRI. Second Edition. Large crown 8vo. 7 s. $6 d$.

- Rarelp are two auccesses followed in due course bp a third success. but all those who deligbted in Mrs. Earle's two first books will eagerly welcome "A Third Pot-Pourrl.",

llLUGTRATED LONDON News.

London: SMITH, ELDER, \& CO., 15 Waterloo Place, S.W. 


\section{A SELECTION FROM SMITH, ELDER \& CO.'S LIBRARY BOOKS}

-A work absolutely Indlspensable to every well-furnlshed llbrary.'-TIMES.

In 66 vols. Price $£ 49$. 10s. net in cloth binding; or $£ 66$ net in half-morocco.

\section{THE DIOTIONARY OF NATIONAL BIOGRAPHY AND SUPPLEMENT.}

Edited by Sir LESLIE STEPHEN, K.C.B., and SIDNEY LEE.

Vols. I. to XXI. Edited by Sir LesLIE STEPHeN, K.C.B. Vols. XXII, to XXVI. Edited by Sir LESLIE STKPHEN, K.C.B., and SIDNEY LEE. Vols. XXVII. to LXIII., and the Three Supplementary Volumes, Edited by SiDNEY LEF.

Also in 1 Vol. of 1,464 pages, rojal 8vo. 25s. net in cloth; or 32s, net in half-morocco.

\section{THE DICTIONARY OF NATIONAL BIOGRAPHY} INDEX AND EPITOME.

\section{Edited by SIDNEY LEE.}

$A T H E N \not E U A .-$ We can conceive no volume of reference more indispensable to the scholar, literary man, the historian, and the journalist.'

*." Prospectus, with specimen pages, post free on application.

A. CONAN DOYLE'S NOVELS. Author's Edition. In 12 vols. With an Introductory Preface and 2 Photogravure Illustrations to each Volume. Large crown 8 vo. 6s. each net.

- This Edition of Sir A. Conan Doyle's Novels is limited to 1,000 sets, the first volume of each set being signed and numbered, and the volumes are not sold separately. The Buthor's future work will, in due time, be added to the edition.

\section{THE 'HAWORTH' EDITION OF THE}

LIFE and WORKS Of CHARLOTTE, EMILY, and ANNE

BRONTË. 7 vols. large crown 8vo. cloth, gilt top, 6s. esch; or in set cloth binding, gilt top,

$£ 2$. 2s. the Set. With Portraits and Illustrations. Introductions to the Works are supplied by Mrr. HUMPHRY WARD, and an Introduction and Notes to Mrs. Gaskell's 'Life of Oharlotte Brontë' by Mr. Clement K. ShorTER, the eminent Brontë autbority.

Also the POPULAR EDITION, 7 vols. small post 8v0. limp cloth, or cloth boards, gilt top, 2s. 6d. each. And the POCKET EDITION, 7 vols. small fep. 8vo. each with Frontispiece, bound in cloth, with gilt top, $1 \mathrm{~s} .6 \mathrm{~d}$. per volume; or, the Set in gold-lettered cloth case, $12 \mathrm{~s} .6 \mathrm{~d}$.

The BIOGRAPHICAL EDITION Of $W$. M. THACKERAY' 8 WORKS. In 13 vols. large crown 8 vo. cloth, gilt top, $6 \mathrm{~s}$, each.

This New and Revised Edition comprises additional material and hitherto unpublished Letters, Sketches, and Drawings derived from the Author's original MSS, and Note-Books ; and each Volume includes a Memoir in the form of an Introduction by Mrs RICHMOND RITCHIE.

* THE THIRTEEN VOLUMES ARE ALSO SUPPLIED IN SET OLOTH BINDING, GILT TOP. £3. $18 \mathrm{~s}$.

* A Prospectus of this Edition, and of the 'LIBRARY' 'OHEAPER ILLUSTRATED. and other editions of Thackeray's Works, with Specimen Pages, will be sent post-free on application.

ROBERT BROWNING'S COMPLETE WORKS. Cheaper

Edition. Edited and Annotated by AUGUSTINR BIRRkLl, K.O., and Frederio G. KrenYON. 2 vols. large crown $8 \mathrm{vo}$, bound in cloth, gilt top, with a Portrait-Frontispiece to eaoh Volume. 7s. 6d. per vol.

* Also the UNIFORM EDITION OF ROBERT BROWNING'S WORKS, in 17 vols. crown 8vo. bound in sets, $£ 4$. 5 s.; or the volumes bound separately, 5s. each. And the POCREET EDITION, in 8 Volumes on India Paper, price $2 \mathrm{~s}$. $6 \mathrm{~d}$. net each in limp cloth; or $3 \mathrm{~s}$. net in leather. Or the 8 Volumes in a gold-lettered case, 22s. $6 \mathrm{~d}$. net in cloth, or 28s. $6 \mathrm{~d}$. net in leather.

ELIZABETH BARRETT BROWNING'S POETICAL WORKS. CHEAPER EDITION. In 1 vol, with Portrait and Facsimile of the MS. of 'A Sonnet trom the Portuguese.' Large crown 8vo. bound in cloth, gilt top, 7s. $6 \mathrm{~d}$.

- Also the UNIFORM EDITION, in 6 vols. small crown 8vo. 5s. each. And the POCKRT EDITION, in 3 Vols. on India Paper, price 2s. 6d. each net in $11 \mathrm{mp}$ cloth, or 3s. net in leather.

MISS THACKERAY'S WORKS. Uniform Edition. Each Volume Illustrated by a Vignette Title-page. 10 vols, large crown 8vo. 6s. eacb.

MRS. GASKELL'S WORKS. Uniform Edition. 7 vols, each containing 4 lllustrations, $3 \mathrm{~s}$. $6 \mathrm{~d}$. eacb, bound in cloth.

- Also the POPULAR EDITION, in 7 vols. small post 8 vo. limp cloth, or oloth boards, gilt top, 2 s. 6d. each. And the POCKET EDITION, in 8 vols. small $\mathrm{fcp} .8$ ro. bound in cloth, with gilt top, 1s. 6d. per volnme; or the Set, in gold-lettered oloth case, $14 \mathrm{~s}$.

Catalogue I'ost-free on application.

London: SMITH, ELDER, \& CO., 15 Waterloo Place, S.W. 




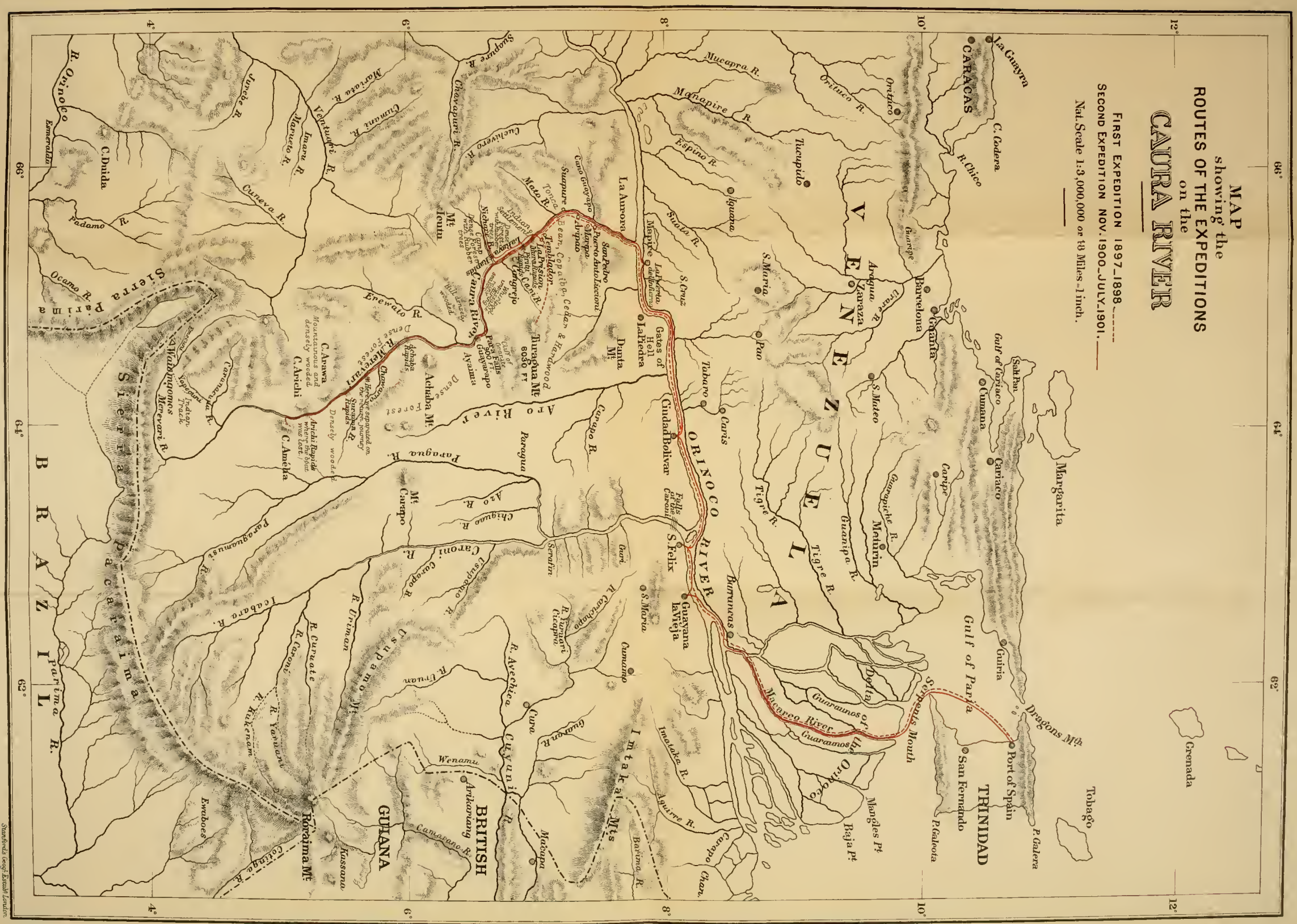






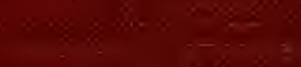

$$
\begin{aligned}
& - \\
& \text { - }=1 \\
& \rightarrow
\end{aligned}
$$

\section{s.s}

$\sec x$
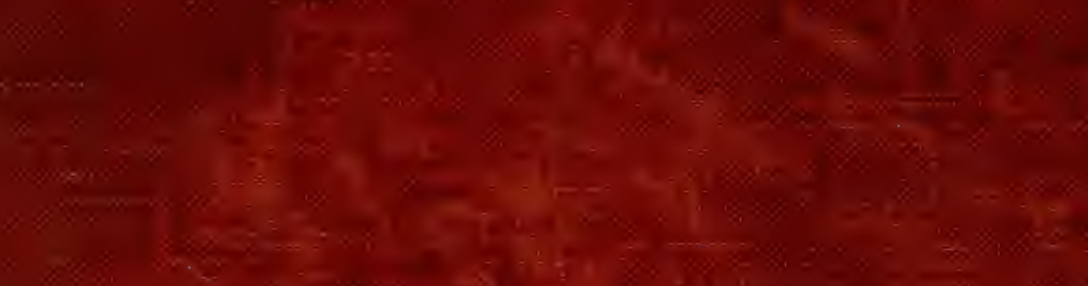

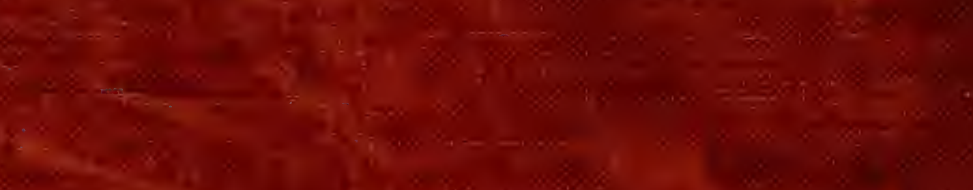

$\bar{x}^{2}$

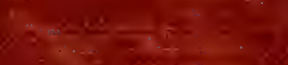

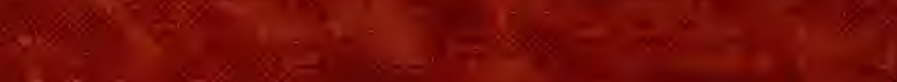

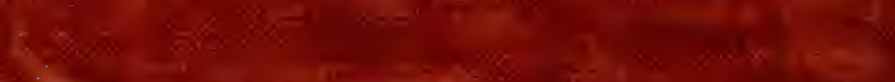

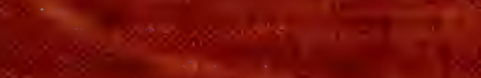

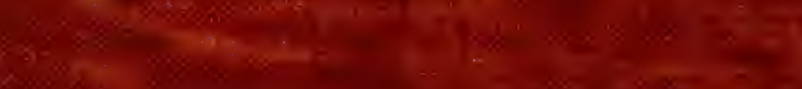

